UNIVERSIDADE DE SÃO PAULO

ESCOLA DE COMUNICAÇÕES E ARTES

LUCAS EDUARDO DA SILVA GALON

Estética e contemporaneidade: por uma outra filosofia da música nova

SÃO PAULO

2016 


\section{LUCAS EDUARDO DA SILVA GALON}

Estética e contemporaneidade: por uma outra filosofia da música nova

Tese apresentada à Escola de Comunicações e Artes da Universidade de São Paulo, para obtenção do título de Doutor em Artes, Programa de Pós-Graduação em Música.

Linha de Pesquisa: Musicologia e Etnomusicologia

Orientador: Prof. Dr. Marcos Câmara de Castro

São Paulo 
Autorizo a reprodução e divulgação total ou parcial deste trabalho, por qualquer meio convencional ou eletrônico, para fins de estudo e pesquisa, desde que citada a fonte.

Galon, Lucas E. S.

Estética e contemporaneidade: por uma outra filosofia da música nova, 2016. 242 p.: il.; $30 \mathrm{~cm}$.

Tese de Doutorado, apresentada à Escola de Comunicações e Artes da USP. Área de concentração: Musicologia

Orientador: Marcos Câmara de Castro.

1. Epistemologia; 2. Filosofia, 3. Filosofia da Arte; 4. Estética; 5. Estética Musical; 6. Ciências; 7. Composição Musical; 8. Idealismo; 9. Materialismo. 
GALON, Lucas E. S.

Estética e Contemporaneidade: Por uma Outra Filosofia da Música Nova

Tese apresentada à Escola de Comunicações e Artes da Universidade de São Paulo, para obtenção do título de Doutor em Artes, Programa de PósGraduação em Música.

Aprovado em

\section{Comissão Julgadora}

Prof. Dr.

Instituição: Assinatura:

Prof. Dr.

Instituição: Assinatura:

Prof. Dr.

Instituição: Assinatura:

Prof. Dr.

Instituição: Assinatura:

Prof. Dr.

Instituição: Assinatura: 
Dedico estes escritos à minha companheira de vida e amiga de todas as horas, Sara Cesca. Sua contribuição intelectual, dedicação incondicional e paciência amorosa estão impressas em cada palavra deste meu trabalho e de todos os meus alfarrábios. Ainda tenho as palavras de Eclesiastes 9:9 impressas em mim. 


\section{AGRADECIMENTOS}

Em primeiro lugar ao meu orientador, Marcos Câmara de Castro: pelas longas e profícuas sessões de orientação (em pessoa ou por escrito), sempre prazerosas, baseadas em sua ética e generosidade acadêmica notáveis; por me ajudar a delinear um trabalho em andamento, dando contribuições sem medida; por confiar em meu potencial mesmo em momentos muito complicados. Sou grato por toda a motivação e ajuda que recebi.

Ao meu antigo orientador (desde os tempos da graduação), professor da vida artística e amigo Rubens Russomanno Ricciardi, não só pelas contribuições na qualificação como pela disponibilidade de sempre em compartilhar de seus vastos conhecimentos e experiências como compositor e musicólogo.

Agradeço ao compositor e amigo José Gustavo Julião de Camargo, com quem tenho compartilhado experiências e reflexões sobre os problemas de nosso ofício de compositor.

Aos meus pais Maria Teresa Galon e Ivo Eduardo da Silva pela sabedoria transmitida em cada conselho; sou grato pelo apoio e motivação, dados desde o início, para que eu enveredasse na profissão de músico e pesquisador.

Aos meus amigos e parentes do meio acadêmico pelas longas e prazerosas horas de conversa e troca de experiências, em especial à minha irmã Mariana Galon, também musicista, com quem compartilho diversos problemas de pesquisa.

Aos colegas professores e músicos de todas as instituições nas quais trabalho: sem a experiência, não haveria pensamento. 


\section{RESUMO}

GALON, Lucas E. S. Estética e contemporaneidade: por uma outra filosofia da música nova. 2016, 242 f. Tese (Doutorado em Artes) - Escola de Comunicações e Artes, Universidade de São Paulo, São Paulo. 2016.

Com a finalidade de propor uma abordagem filosófica em torno de diversos problemas atuais da estética musical, em especial buscando identificar e situar uma crise existente na sua elaboração disciplinar, serão lançados nesta tese estudos sobre a problemática relação da estética com outros campos do conhecimento, tanto aqueles vinculados às ciências empírico-matemáticas quanto às ciências humanas. Questões centrais sobre a relação entre as artes e a filosofia, sobre o papel e a situação do esteta moderno, e sobre as tendências da composição musical contemporânea também serão abordadas, sempre no intuito de apresentar possibilidades epistemológicas para uma nova estética musical que sejam consubstanciais aos problemas das artes e da música contemporânea, bem como elementos para definições de arte e da música que sejam alternativas à histórica pregnância na modernidade do pensamento de vanguarda. Para tanto, esta tese se divide em quatro grandes ensaios, pretendendo-se que possam ser tomados, para além de sua unidade temática e estrutural, também isoladamente.

Palavras-chave: Epistemologia; Filosofia, Filosofia da Arte; Estética; Estética Musical; Ciências; Composição Musical; Idealismo; Materialismo. 


\begin{abstract}
GALON, Lucas E. S. Aesthetics and Contemporaneity: for another philosophy of the new music. 2016, 242 f. Tese (Doutorado em Artes) - Escola de Comunicações e Artes, Universidade de São Paulo, São Paulo. 2016.

In this dissertation, studies about the problematic relationship of aesthetics with other fields of knowledge, as those bound to empirical-mathematical sciences as well to human sciences, will be launched with the goal of proposing a philosophical approach around various current musical aesthetics problems, specially aiming to identify and to situate an existent crisis in its disciplinary elaboration. Main questions about the relation among arts and philosophy, about the role and situation of the modern aesthete, and about trends of contemporary musical composition will be broached as well, always intending to present epistemológical possibilities to a new musical aesthetics that are consubstantial to the problems of arts and contemporary music, as well as elements for definitions of art and music which may be alternative to historical impression of modernity on avant-garde thinking. Therefore, this dissertation is divided in four great essays, with the intention that they may be taken, over and above its thematic and structural unit, also separately.
\end{abstract}

Keywords: Epistemology, Philosophy, Philosophy of Art; Aesthetics; Musical Aesthetics; Sciences; Musical Composition; Idealism; Materialism. 


\section{SUMÁRIO}

Nota preliminar. 1

\section{Introdução}

I. Acusações à Estética. 9

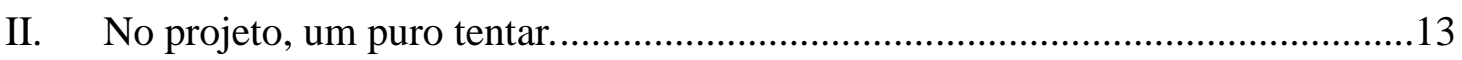

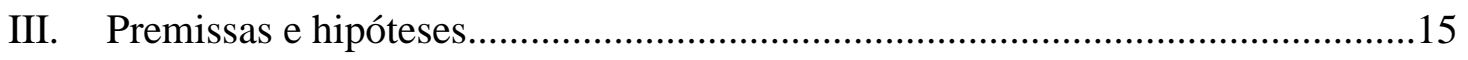

\section{PARTE I - Problemas Epistemológicos: Possibilidades para a Estética}

1. Filósofo, artista.

1.1 Problemas no alvorecer da estética. .30

2. Três estudos de caso

Dilemas conceituais: arte e filosofia; unidade e prescrição; poética e estética.

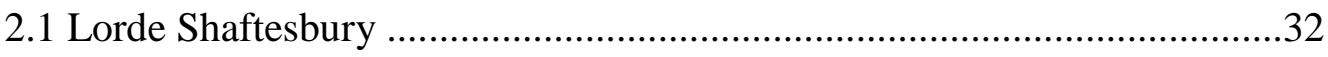

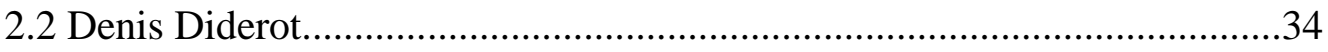

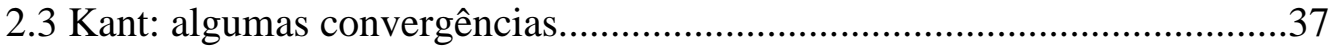

3. A ideia de música absoluta como um intermitente problema da estética.........41 Convergências: a metafísica do absoluto e a mística pitagórico-platônica; unidade e consistência.

4. Algumas conclusões e aplicações para um pensamento atual: a concretização de uma hermenêutica da consistência.

4.1 Por uma organização disciplinar.

PARTE II: A Estética, a Teoria Musical, e a So(m)bra da Ciência: Possibilidades Epistemológicas para uma Estética Contemporânea

5. Del rigor en la ciência

5.1 Sobre os limites e vícios da ciência: a possibilidade de cientifização da estética. 
5.2 Problemas conceituais na abordagem teórico-musical: a escolha pela estética.

5.3 A natureza da estética; as múltiplas conotações de teoria; o vínculo da vanguarda com o paradigma dominante; por um paradigma emergente para a música.

\section{Parte III - Por uma Definição de Arte para a Contemporaneidade} É possível uma definição de arte? É possível uma estética musical materialista?

\section{Prefácio à Parte III}

- Rumo a uma definição de arte. .95

- Rumo a uma possibilidade estética. .96

7. Introdução aos problemas para uma definição de arte: a exigência do novo explícito.

8. A Necessidade de uma Definição de Arte: O Mundo da Obra e o Mundo das 'Meras Coisas' e A Recuperação de uma Pregnância Material. 106

9. Três Estudos de Caso: Coisa e Transcendência na Arte Através das Obras.....112

9.1 Heidegger e a retirada da obra do mundo das coisas

9.1.1 O complexo matéria-forma

9.1.2 Comparação entre o apetrecho e a obra de arte.

9.1.3 Heidegger propõe um modo de investigação

9.1.4 O papel do artista

9.1.5 A obra se retira para terra; e produz terra nesse retirar-se. 
9.1.6 Pertence à essência da verdade negar-se sob o modo da dupla ocultação

9.1.7 Em Heidegger algumas conclusões: caminho rumo ao elemento material.

9.3 Em Dino Formaggio a reintrodução do corpo: perfazendo uma definição de arte.

10. Música, algumas implicações: liquidez, metalinguagem e uma teleologia negativa. 148

\section{PARTE IV - Situação da Arte e da Música na Contemporaneidade: Paradoxos na Estética da Vanguarda}

11. Introdução 165

12. A construção do mainstream e o vício Boulez. .168

13. As perspectivas da música no ambiente da morte da arte 180

14. A arte, a obra, e o mundo das coisas sob o índice do nada, da morte e da vontade de aniquilação: $o$ i-mundo da arte. 190

15. O que se revela no caso da música. .197

15.1. Ingenuidades e paradoxos: determinação, indeterminação e silêncio na música da vanguarda.

15.2 A pulverização da vanguarda musical em outras possibilidades estéticopoéticas .204

16. Por uma definição de arte permeável: a integração de mais um elemento. .206

Conclusões 


\section{Apêndice}

I. A Atualidade do Festival Música Nova.....................................................219

Referências bibliográficas 
NOTA PRELIMINAR 


\title{
Estética e contemporaneidade: por uma outra Filosofia da Música Nova
}

\begin{abstract}
La música, los estados de la felicidad, la mitología, las caras trabajadas por el tiempo, ciertos crepúsculos y ciertos lugares, quieren decirnos algo, o algo dijeron que no hubiéramos debido perder, o están por decir algo; esta inminencia de una revelación, que no se produce, es, quizá, el hecho estético. (Jorge Luis Borges)
\end{abstract}

\section{Nota preliminar}

Não por estar se tornando comum, até mesmo protocolar; não por acreditar em qualquer necessidade intrínseca, ou mesmo imanente, relativa aos pressupostos dos novos tempos: em verdade, essas notas preliminares - não sendo intrinsecamente necessárias, e não ocorrendo com o intuito de um cumprimento de protocolo, uma vez que cada vez mais em trabalhos acadêmicos certa pregnância pessoal se faz presente são um aparte, embora peculiarmente inicial, que busca aferir ao presente trabalho uma dimensão menos pretensiosa do que poderia parecer à primeira vista, mesmo àquele leitor menos preconceituoso. Assim, assumo de saída uma posição despretensiosa, para equilibrar as coisas, naquilo que considero apenas um dentre os vastos campos onde respostas são possíveis para as perguntas que pretendo de alguma forma responder. Aqui se trata de um trabalho numa de suas etapas, trata-se de um trabalho assumindo-se honestamente relativo à minha experiência, e, naquilo que deve, ou ainda pode permanecer como ciência, tem sua pretensão mais aberta com respeito à possibilidade de alguma tendência a universalizar (palavra maldita!) determinados pontos; ou pelo menos tentar expandi-lo ao limite de suas possibilidades de generalização. Não postulo uma teoria. Mas procuro examinar assuntos que considero urgentes. Não serei prescritivo, mas procuro lançar "alguma" prescrição. Não pretendo ser crítico, mas alguma crítica se fará necessária. Escapando da pretenciosidade, ainda devo dizer que corro o risco, com respeito a este alguma, da acusação de manter-me em cima do muro, a meio caminho de qualquer coisa mais relevante. Defendo-me alegando que prefiro que não haja muros. Se minhas hipóteses circulam em torno da possibilidade de uma 'nova' filosofia da música, examinando mais os obstáculos para sua existência do que 
prescrevendo normas - o que, segundo Luigi Pareyson, levar-me-ia a algum lugar distante da estética - é justamente porque compreendo que a estética, pensada enquanto filosofia da arte, deve superar os seus malogros de legitimadora histórica de valores aristocráticos, de construtora de cânones ${ }^{1}$ e avatares que prevaleceram por muito tempo incontestáveis. É porque penso que seja confuso o modo como se relacionam as epistemologias no campo da música, ora tendendo para uma hiperdivisão dos campos em especializações cada vez mais autônomas, onde qualquer hermenêutica mais geral dos problemas da música me parece impossível, ora desaguando num estranho paradoxo onde os campos se misturam inadvertidamente.

Ao que parece, esta especialização tende a afastar a possibilidade de um pensamento mais abrangente, multiplicando os campos, e especificando-os ao limite do que supostamente se considera o trabalho científico. Esse limite, muitas vezes, pode ser a penetração descuidada em outro campo; e pior: é porque penso que toda radicalização de um pensamento estético redunda em seu oposto, principalmente na era dos extremos e paradoxos, a contemporaneidade. Ou, sobre as possibilidades de pensar, como assevera o ainda pouco estudado no Brasil, o filósofo da arte Dino Formaggio: "quanto mais se pensa mais se move e se relativiza até converter-se em sua polarização extrema" (FORMAGGIO, 1976, p.115). É assim que enxergo os campos da pesquisa e do pensamento sobre a arte: hiperindividualizados pela ânsia epistemológica de certa ideia de ciência, porém com fronteiras embaçadas, confusas. Este é apenas um dos paradoxos que serão apontados nesta tese. Por fim, sem constrangimento, veremos que uma das constantes legadas pelos extremos da música e da arte contemporâneas reside em paradoxos que se desvelam na relação das obras com o pensamento sobre elas; e na própria relação entre campos de análise das artes.

No intuito de realizar um trabalho estético, em tempos tão antiestéticos; assumindo deliberadamente a posição de um músico-compositor manuseando com aquilo que não é somente um braço da filosofia, mas a filosofia inteira e jogando com reflexões muitas vezes consideradas áridas e infecundas em tempos de super especialização dos campos examinadores da arte e das obras. É-me necessário, e no

\footnotetext{
${ }^{1}$ Faço inicial referência ao uso do termo 'cânone', que terá aqui uso corrente, aludindo sempre aos modernos estudos que procuram investigar, a partir de certas pregnâncias sociológicas e antropológicas, as estratégias político-ideológicas que tornaram terminadas expressões artísticas hegemônicas na história. Obviamente podemos ligar estes estudos e estas disciplinas, no caso da relação deles com a estética, principalmente à dimenção da recepção. Estes estudiosos estão especialmente ligados às publicações da Universidade de Cambridge, como William Weber (1999).
} 
decorrer de minhas reflexões tem me parecido cada vez mais patente, justificar-me acerca do modo, do como e do porquê eu delineei meu caminho através dos campos (às vezes pantanosos) que aventam a possibilidade de uma filosofia da música. Se a imensa maioria dos compositores dedica-se à pesquisa dentro daquilo que abarca o seu métier mais óbvio, a saber, a teoria e a análise musicais, porque eu, compositor e músico de ofício, me detenho, desde a graduação, nos problemas filosóficos do campo da estética musical, pensando-a quase como uma incontingência, um esbarrar obrigatório do meu ofício?

Levantadas essas questões, e, principalmente, as minhas intenções com essas notas, devo expor, portanto, ainda dois aspectos que me levaram - sendo músico e compositor - ao caminho da filosofia. Não me atenho aqui às autoanálises psicológicas ou ontológicas, tampouco questões de cunho cultural e social - não se trata de minha biografia - o que me levaria a esbarrar, sem demora, em uma espécie de kitch acadêmico, levando o paciente leitor ao percurso errante da escrita de cunho ficcional.

O que pode contribuir evidentemente para as questões que pretendo levantar tem a ver com aspectos relevantes na minha experiência pessoal, que me levaram ao universo da estética musical, que ao meu ver podem contribuir para a compreensão de certos aspectos que serão levantados. Mas antes de prosseguir, devo delinear rapidamente sobre aquilo que, já exposto no título deste trabalho, inconscientemente cobra o leitor: a qual música nova me refiro? Pois bem, defino já como uma posição estética a escolha de como conceituar a música nova, por isso, essa resposta aparecerá paulatinamente no decorrer deste trabalho, onde o novo também é um objeto colateral.

Para os fins desta nota, basta a consciência do essencial: refiro-me às manifestações da música contemporânea ligadas à tradição musical ocidental (grecoromana), oriunda de um encadeamento de sínteses, e, por isso mesmo, resistente às definições mais precisas, mas que no Brasil é tratada de forma mais ou menos canônica como música erudita ou música clássica ${ }^{2}$. No caso me refiro a esta música contemporânea como nova buscando uma relação de fundo com aquilo que foi tratado como neue Musik (tudo que esteja atrelado a Darmstadt) no século XX. Isso posto, prossigo na descrição do percurso que me levou a pensar especificamente dentro do campo a que agora me proponho.

\footnotetext{
${ }^{2}$ A terminologia para este caso é confusa. Muito se tem discutido, especialmente com relação às possibilidades de tradução do inglês e outras línguas, sobre como chamar essa música. Particularmente devido às manifestações da música da indústria da cultura e do music business, tenho optado por música de concerto. Mas dependendo do contexto, é melhor optar por outra terminologia.
} 
Em primeiro lugar, a minha inicial atividade como músico de orquestra sinfônica, que, sendo em si um microcosmo riquíssimo, me levou, com certa constância a pensar, por exemplo, nas razões que me faziam executar quase sempre determinado repertório (o clássico-romântico), das razões pelas quais o gosto de meus colegas músicos frequentemente não coincidiam com o campo de suas atuações, do porquê, enfim, a orquestra me parecia, em algumas ocasiões, como algo "fora de lugar". E algumas das minhas mais ingênuas perguntas: o que quer dizer a música instrumental? Será essa a razão maior da resistência, no Brasil, às atividades de uma orquestra sinfônica (já que o repertório é majoritariamente composto por música instrumental), a ausência da linguagem verbal direta, inteligível? Qual é a função e o lugar da arte da música nos dias de hoje?

Em segundo lugar, a minha atividade como compositor. "Minha atuação na orquestra me levará ao domínio mais amplo da instrumentação, ao maior contato com as 'engrenagens' das obras, ao conhecimento técnico mais preciso". Em parte, minhas intenções foram recompensadas. Mas também eram ingênuas na medida em que percebi que, se cada nova obra minha um problema técnico - e aqui devo perfazer a definição heideggeriana, onde neste caso, arte é a $\tau \dot{\varepsilon} \chi v \eta$ grega mesmo - era passível de resolução, se cada obra é um problema em si mesma a ser resolvido, ficou-me claro também que a feitura do tecido musical, os problemas relativos ao artesanato da obra, à sua produção, ao aspecto - que eu esteja livre da heresia! - "fabril" da obra musical eram apenas o aspecto do que fazer para dizer algo de outra forma. Parece óbvio, mas não é tanto. A produção de cada obra, desde o insight (me apropriando aqui deste termo no sentido pareysoniano) até a sua conclusão, vem impregnada de questões filosóficas que encerram em si um problema que transcende esse aspecto fabril, e aqui, ainda perfazendo uma definição heideggeriana, o problema é que a obra de arte também se dá enquanto $\alpha \lambda \dot{\eta} \theta \varepsilon 1 \alpha$. De perguntas cuja pertinência, no tocante à obra de arte musical, especialmente às obras instrumentais, sem texto, são de difícil resposta, como "o que quero dizer?", "o que quero dar a pensar?" e "a quem me dirijo?". Se tais respostas, na poesia ou na pintura, não possuem o agravo da necessidade do lançamento de uma distinção radical entre o aspecto artesanal e o conceitual-filosófico, que apareceriam como uma dialética cuja iminência da sua resolução é a condição da compreensão da própria arte, na produção da música elas se tornam urgentes, e mais: apresentam gradações tão evidentes, que ignorá-las é ignorar a existência de uma coisidade e um $\lambda$ óyo diferente em cada arte. Pode-se entender coisidade de muitas formas. Se para 
Heidegger, toda sinuosidade aparentemente circulatória do pensar sobre a coisidade da coisa apenas demonstra a impossibilidade de se achegar ao que de mais simples se pode obter - saber o que seria a própria coisa - então, para o que me interessa, o mais difícil seria compreender o caráter coisal (Dinghaft) da arte, ou seja, o que a define enquanto arte, o que, dentro de uma perspectiva de cunho idealista poderia levar à distinções cujo limite é um risco, justamente o risco de uma nova e equivocada guinada à uma metafísica da arte. Para Dino Formaggio, um certo anti-idealismo, característica marcante de sua obra Fenomenologia della tecnica artistica (1953), é uma condição para a superação dos pressupostos tradicionais, que levam à possibilidade de pensar a arte a partir de "uma contribuição para a renovação dos estudos estéticos que, após a 'ditadura' idealista, vai sendo por muitos sentindo a urgência ${ }^{3 "}$. Se o contato com os autores e teóricos sempre pôde indicar caminhos para as respostas que a invenção de minhas próprias obras puderam dar, ao mesmo tempo determinadas questões parecem residir numa parcialidade inexorável das respostas, quando olhadas pela lente da univocidade pretendida por qualquer possibilidade de hermenêutica. $\mathrm{O}$ que, em outras palavras, quer dizer: nem todos os campos que se propõem a examinar a música por alguma perspectiva consideram essas questões relevantes. Na verdade a consolidação da indústria da cultura a partir do século XX parece ter criado novas distinções, complicando as tentativas de postular qualquer coisa em termos de arte, especialmente de música. Por outro lado, as radicalizações que desde o início do século XX - e no caso das artes esta foi realmente "a era dos extremos" - tomaram conta das manifestações artísticas de vanguarda, provocando aquilo que talvez sejam os únicos casos de 'ruptura' de fato na história das artes, resultou, no caso da música, não só num afastamento do público, mas também de muitos intérpretes e artistas do próprio meio.

$\mathrm{O}$ resultado me parece que reside em paradoxos; paradoxos que geram as perguntas levantadas anteriormente. Parece-me que, de fato, o lançamento de questões cada vez mais profundas sobre a função, o papel e as possibilidades da música e das artes nos dias de hoje, se ela ainda reside em seu caráter de produção (poiético, em

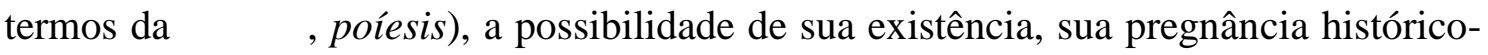
social, a diferença entre as manifestações clássicas e populares, o caráter distintivo desta música numa sociedade colonizada, enfim, todas estas questões hoje circulantes em um multiverso disciplinar, têm como pano de fundo exatamente um grande numero de

\footnotetext{
${ }^{3}$ E. Garroni, La crisi semantica delle arti, Officina, Roma, 1964, p. 113-4, a propósito das contribuições de Dino Formaggio, citado no prefácio de FORMAGGIO, 1953.
} 
narrativas totalizantes (totalizing narratives, nos dizeres de Nicholas $\mathrm{Cook}^{4}$ ), bastante presentes no anseio pelo universal em cada campo, e que é imanente em qualquer teoria, e que, pensadas em suas formas mais radicais, deslizam para o seu oposto. Esse é sem dúvidas o seio que acolherá o desenvolvimento das hipóteses deste trabalho. Assim, veremos que tanto num plano estético-teórico quanto no plano musical, os radicais se tocam: os extremos da arte contemporânea que parecem emergir de um materialismo radical de vanguarda parecem ter desaguado num idealismo radical de retaguarda. No plano teórico, mesmo em sua dialética concreta da pratica técnica e social da arte, Dino Formaggio, que aponta para um caminho assumidamente mais materialista, em muitos aspectos, numa leitura mais rígida, pode levar a uma legitimação dos pressupostos da vanguarda tecnicista da música, idealista por excelência. Eis mais um paradoxo.

Minhas questões iniciais, por mais ingênuas que fossem, levantaram problemas que, para muito além do técnico-artesanal, tocam diretamente na dimensão daquilo que a obra é, daquilo que ela fala (linguagem), qual é a sua função e porquê eu a faço. Isso não seria também radicalmente condicional à produção de uma obra de arte, justamente este pensar esteticamente? Talvez não. Talvez não seja próprio da composição musical, ou mesmo da atividade artística, essa necessidade. É provável que, sem jamais postular essas questões, um compositor faça suas obras de forma perfeitamente consistente. No entanto me parece indubitável que questões tão simples atinem diretamente ao âmago de uma disciplina que pretende compreender a existência de algo a que chamam 'arte', e que, pelo menos na especificidade do meu caso, ao âmago do próprio ato de compor.

Mesmo assim, este não é exatamente um estudo de caso (no caso, o meu). É a tentativa de encontrar constantes a partir da minha experiência que sejam generalizáveis, no intuito de melhor compreender os rumos da música e da estética musical para os dias de hoje. A minha escolha artística tem como posição condicional uma boa estética e uma boa "doutrina artesanal", algo um pouco distinto da já antiga aporia de Arnold Schönberg ${ }^{5}$ (problema levantado inicialmente pelo musicólogo Rubens Russomanno Ricciardi, 2013), que aparecerá, vez ou outra, neste trabalho.

Por fim: se de fato cada obra é um problema de fabricação em vias de ser solucionado, isso atina diretamente à poética, "este fazer que, enquanto faz, inventa o por fazer e o como fazer", na já famosa sentença de Luigi Pareyson. Mas a feitura da

\footnotetext{
${ }^{4}$ No prefácio de The Cambridge History of Twentieth-Century Music (2004).

${ }^{5}$ Schönberg afirmou "ter orgulho em escolher uma má estética para os alunos de composição, se em compensação der a eles um bom aprendizado de artesanato" (SCHÖNBERG, 1986 [1911], p.6).
} 
obra também encerra um problema sociológico: para quem se faz ou porquê se faz. Um problema histórico: quando se faz e o que se faz depois com o que se fez. E ao cabo, um problema estético, filosófico: o que se quer dizer com o que se faz, e o porquê o feito foi feito e como foi feito. 
INTRODUÇÃO 


\section{Introdução}

\section{Acusações à Estética}

Hoje, não são poucos os livros que se referem à estética musical. Mas há poucos de estética musical propriamente dita. $\mathrm{O}$ fato se explica pela desconfiança geral em relação às possibilidades de que a filosofia possa dar conta de alguma coisa nos tempos atuais. Seja qual for o modo como se compreenda a filosofia hoje - invenção de conceitos, história da filosofia, viver a própria filosofia (como em Onfray) etc. verifica-se um seu desvanecer nas ciências humanas, especialmente na história, na antropologia e nas ciências sociais; e no caso da música, nas ciências empíricomatemáticas. Em realidade temos que, em plena era das especialidades e do rigor epistemológico, algo paradoxal se levarmos em conta a plenitude dos relativismos como pensamento que tende a ser dominante, a filosofia seja declarada morta enquanto impossibilidade do pensamento; pelo menos no que diz respeito às possibilidades que ela apresentava anteriormente (especialmente até o século XIX) ao lançar grandes narrativas, discursos totalizantes, ou, para falar de uma forma menos arriscada, lançar hermenêuticas mais gerais sobre os problemas do homem e do mundo. Neste sentido, é óbvio que as narrativas totalizantes deixaram o domínio da filosofia, pelo menos depois de Niestzche, para se tornarem domínio da crença na ciência.

Quando Stephen Hawking ${ }^{6}$, o mais afamado cientista da segunda metade do século XX e início do século XXI, ao especular sobre os problemas inerentes à compreensão do mundo, do cosmo, do universo e do homem, lança em um de seus best sellers a seguinte sentença:

\footnotetext{
${ }^{6}$ Lanço mão aqui de uma citação do cientista Stephen Hawking não por considerá-lo necessariamente um paradigma para a ciência moderna desenvolvida na academia, mas por sua importância e impacto na divulgação da ciência, realizada em larga escala. Sendo provavelmente o maior (pelo menos pioneiro) e talvez o mais acessível divulgador das complexas modernas teorias científicas para o grande público, é inegável que o alcance de suas ideias para formação de um senso comum, ou mesmo na communis opinio acadêmica - esse senso comum douto - têm produzido um corpus bastante definido, apoiado pela publicidade de seus livros e pelo cinema de Hollywood, onde ele não é exceção. Basta vermos como as ideias do físico Kip Thorne, além do próprio Hawking, resultaram no filme Interestelar, "arrasaquarterão" em 2014. Como o que me interessa aqui é justamente o impacto cultural que determinada ideia de ciência possa ter, e em especial tomando aquilo que ela pode legar enquanto pensamento filosóficoespeculativo para a própria comunidade cientifica (ultimamente nada alheia à publicidade em larga escala e ao capital) me parece apropriado tomar este que é um dos maiores divulgadores de um moderno positivismo cientifico.
} 
Tradicionalmente, essas questões são do âmbito da filosofia, mas a filosofia está morta. Ela não acompanhou os desenvolvimentos modernos da ciência, em particular da física. Os cientistas passaram a portar a tocha da descoberta, em nossa busca pelo conhecimento (HAWKING, p.7, 2010).

Vemos que os sinais se tornam evidentes: a era do positivismo não acabou. Sua pregnância se faz presente de forma patente, não só nas ciências duras, ditas 'exatas', mas, mesmo de forma mais sutil, em todas as outras ciências.

Em se tratando do presente trabalho, a demonstração dos malogros que a suposta morte da filosofia pode trazer, caudatária justamente dos malogros que a persistência do positivismo continua trazendo, se substancia como um dos objetivos colaterais de toda abordagem que pretendo realizar. Como já se pode imaginar, se a filosofia está sendo declarada morta - e sempre há declarações de morte direcionadas às mais variadas possibilidades do pensamento ${ }^{7}$ - e a ciência é declarada o único caminho para um seguro conhecimento do mundo, tem-se como desdobramento que à estética pensada enquanto filosofia da música se atribua não só o epíteto de "moribunda", como de ignorante dos problemas em torno de sua suposta agonizante existência. Aprofundandose mais ainda no problema, temos que, especificamente na estética musical, a desconfiança é ainda mais evidente, uma vez que, pelo parentesco essencial da música com as ciências matemáticas e físicas, a tocha do conhecimento passa a ser de fato reivindicada pelos cientistas da música, ou pelo menos por aqueles que, em não recebendo a tocha, deveriam receber a pecha.

Carole Talon-Hugon, em seu pequeno, mas famoso compêndio sobre estética geral (TALON-HUGON, 2008, p. 94-95), levanta, no último capítulo, uma série de objeções com relação ao que ela chama "a estética do futuro". Essas objeções se encontram de certa forma no bojo do pensamento dito pós-moderno, especialmente se encaixando no conceito de pensiero debole de Giani Vattimo, ou mesmo nas considerações sobre a inefabilidade da obra de arte postuladas por Lyotard. A essência destas objeções se apresentam, em linhas gerais, nas seguintes constatações: a) diz-se

\footnotetext{
${ }^{7}$ Antecipo aqui dois aspectos deste problema, que serão desenvolvidos na segunda parte deste trabalho. É impossível, a partir daquilo que me proponho a fazer, uma análise sobre a situação da filosofia da música e da situação das artes a partir do século XX sem passar pelos conceitos de nada, nulificação e morte. Também se faz necessário discutir o problema no âmbito da ciência, como o faz com a severidade e a contundência de sempre Paul Feyerabend, que não hesita: "a história da ciência está cheia de teorias que foram declaradas mortas, mas depois ressuscitaram, a seguir novamente declaradas mortas, para mais uma vez comemorarem um triunfal regresso. É lógico conservar pontos de vista errados para possível utilização futura. A história das ideias, métodos e preconceitos constitui uma parte importante da atual prática da ciência e esta prática pode mudar de rumo de maneiras surpreendentes" (FEYERABEND, 1991, p. 45).
} 
que o esteta não sabe o que fala e invoca a arte precisamente por não conhecer as artes; b) o esteta frequentemente "não vê" as circunstâncias sociais e históricas da produção artística, numa crença na absoluta autonomia e autocompletude da obra. Para Pierre Bourdieu a estética é o local da negação do social; c) o discurso estético também é acusado "de ser um discurso metafísico aplicado à arte, uma reflexão que não parte da arte e das obras, mas de uma certa ideia do que a arte deve ser". Censura-se assim, na estética, o discurso especulativo metafísico e vazio; d) a multiplicação (sem dúvida epistemológica) das aproximações às artes operadas pelas ciências humanas significa a dissolução do campo da estética nas outras ciências, que abrangem nos últimos tempos a psicologia, a psicanálise e as ciências cognitivas. E aqui, a estética da música, por sua própria natureza tende a diluir-se nas possibilidades teórico-analíticas; e) o discurso filosófico sobre a arte é ilegítimo: contesta-se na estética o estatuto de ciência rigorosa, "a pretexto de que seus objetos têm um caráter subjetivo" (cf. TALON-HUGON, 2008, p.94-95).

Apesar do fato de Talon-Hugon apresentar respostas interessantes a essas objeções, buscarei, de uma forma ou de outra, no momento oportuno, respondê-las no âmbito do pensamento sobre música e estética que será proposto.

Não é possível o postulado de uma nova possibilidade de se pensar a estética musical contemporânea sem que se assuma, de saída, que algumas dessas "acusações" são justas: a história da estética pode demonstrar a culpabilidade da disciplina no que diz respeito a muito do que os acusadores apontam. Noutros casos, no entanto, as acusações demonstram apenas que o bom e velho duelo entre os campos de atuação da pesquisa continua latente, e a conveniente ignorância sobre o papel que a estética poderia assumir no mundo contemporâneo ideologiza sutilmente a questão.

Para que se possa clarificar o que até aqui foi colocado, proponho agora uma exposição geral comentada sobre aquilo que tenho como premissa e quais hipóteses foram geradas para a discussão destas premissas. Por isso, esta introdução vem assumindo um caráter sutilmente ambíguo: tem o objetivo de expor em linhas gerais o que será tratado; mas já pretende tratar, em alguns casos, com o tratamento comumente dado mais tarde aos temas, nos capítulos que se seguem, em sua divisão pretensamente tradicional dos assuntos. 
Esta latência de determinadas conclusões antecipadas, acolherá, de antemão, duas questões fundamentais:

1) pretendo assumir uma postura filosófica aparentemente paradoxal, onde ora as epistemologias são melhor utilizadas levando em consideração uma mais dura divisão dos campos de análise - uma estética da música específica, sem a "contaminação" das outras artes ou epistemologias de outros campos (sociologia e história, por exemplo), onde a música clama por sua especificidade - ora se faz necessária a apropriação da estética de outras artes para, através da comparação, desvelar as especificidades, ou mesmo pela assunção, desde já, de que há, no tocante à certos temas, um aprofundamento por vezes maior das estéticas de outras artes, especialmente das visuais. E porque a materialidade de outras artes, em certos casos mais diretas e acessíveis a partir de certos pontos de vista, podem clarificar aspectos da música tomados como obscuros.

2) É preciso assumir uma posição no que diz respeito a um quadro por onde uma definição de arte possa se constituir. Ou seja, um paradigma. Por hora, basta a consciência do essencial: tomo como fundamento a ideia de que existe arte e existem obras de $\operatorname{arte}^{8}$, o que de muitas formas pode ser tomado como um paradigma idealista. Buscarei mostrar que uma compreensão mais larga da noção de 'obra', de 'arte' e também de 'artista', pode salvar esse paradigma de se concretizar enquanto uma metafísica, desde que ela possa dialogar com as vocações menos canônicas que a compreensão de arte vem tomando na contemporaneidade.

A assunção deste paradigma é consubstancial ao que apresentei em minhas notas preliminares; em outras palavras, minha poética musical, meu ofício de compositor assume que, o que eu faço, são obras. E o campo em que atuo, é o das artes (e não da indústria da cultura).

Como tem sido perceptível ao leitor deste trabalho, desde o início vão se imbricando de forma metalinguística forma e conteúdo (falo assim por um vício de linguagem). Não só pela minha necessidade de comentar a construção do pensamento na medida em que ele vai sendo construído, mas pela necessidade de falar assim para

\footnotetext{
${ }^{8}$ Por óbvio que possa parecer, é necessário assumir este paradigma. Longe de querer propor um exame exaustivo deste tema, que por si só seria uma tese inteira consubstancial a certas ideias que venho apresentando, basta sabermos que todo um trabalho de grande fôlego vem sendo realizado por Lydia Goehr, especialmente em seu The Imaginary Museum of Musical Works de 1992. Por uma outra vertente, o caso de John Cage, que entre suas propostas não assumia o caráter de "obra" das suas músicas, propondo uma terminologia amplamente discutida em suas cartas com Pierre Boulez onde suas propostas composicionais, por assim dizer, se concretizavam naquilo que ele mesmo chamava como processo musical.
} 
que o que é falado possa ganhar maior relevância ${ }^{9}$. Por isso essa escolha, por assim dizer, 'metodológica' para a construção de um pensamento estético, é já parte das conclusões sobre as possibilidades de uma estética contemporânea, justamente a minha proposta fundamental. Faço assim uso do método que proponho na feitura da própria proposta.

Neste ponto, antes que eu prossiga, e para que se compreenda e se discuta possibilidades a priori para uma estética nos dias de hoje, e possamos seguir mais ou menos seguros das possibilidades de responder sobre questões consideradas importantes no tecido de uma estética da música contemporânea, devo deixar claras as minhas intenções, o meu projeto, mesmo que aqui eu acabe por ceder, à revelia, ao protocolar, ao necessário-acadêmico, interrompendo o livre fluxo das ideias.

\section{No projeto, um puro tentar}

A forma mais livre de um ensaio - e desde pelo menos os tempos de Michel Eyquem de Montaigne (1533-1592) tão adequada a questões estético-filosóficas ou relativas às artes - talvez nos permita caminhar por entre os temas da pesquisa num constante cruzamento entre passado e presente, entre filosofia, artes e ciências, entre as questões centrais e várias de suas implicações, como se notas de rodapé adentrassem a todo instante no texto principal. Esta tese na forma de vários ensaios se aproxima assim também de uma aula em que os assuntos pontuais são expostos através das mais diversas ilustrações.

Assumo, então, a pretensão de expor um pensamento sobre as possibilidades para uma nova estética carregada da ideia de tese, tecendo-o de forma mais ensaística, me mantendo em flertes perigosos com um traçado mais livre, porém procurando não me desatrelar da práxis acadêmica na qual este trabalho se insere; por isso conscientemente assumo este puro tentar de um estudo estético que tenha a música como o centro das reflexões, para as quais inúmeros autores serão chamados, de modo que se possa pensar com eles; apesar deste 'traçado mais livre', não me atreverei a navegar ingenuamente nas águas profundas da filosofia sem a ajuda desses autores.

\footnotetext{
${ }^{9}$ Determinados ensaios, obras de maior fôlego ou estudos, utilizam-se deste artifício, ao meu ver. Em sua concisa, mas monumental A origem da obra de arte (1935) e mesmo em A caminho da linguagem (1959), Heidegger tece um complexo exame dos problemas mais derradeiros da arte e da linguagem através de textos cuja linguagem me parece uma tentativa de um dizer diferente, poético, de modo a provar a própria fórmula. A lógica e os postulados do amplo conceito de polifonia, desenvolvido pelo afamado "Círculo de Bakhtin" não poderia encontrar melhor comprovação nos sistema onde os múltiplos autores se fazem um.
} 
Antes, a música, e o pensamento digno de sua natureza, serão o guia pretendido nas exposições. Minha intenção é que cada uma das quatro grandes partes desta tese possam ser tomadas também como ensaios isolados. Por isso, alguns temas se apresentarão de forma recorrente, mesmo que assumindo a cada momento novas conotações, intermitência que julgo necessária para manter a unidade e ao mesmo tempo dar conta da complexidade das relações temáticas.

No que diz respeito à bibliografia, posso assumir, sem constrangimento, o mesmo ecletismo que marcaram os estudos contidos em minha dissertação de mestrado. Assim sendo, em linha gerais, e de forma bastante implícita, utilizo a certa tradição da estética contemporânea italiana como mediadora entre o idealismo e a fenomenologia alemãs e uma certa tendência do materialismo francês.

Dado que postulei, já de muitas formas, as justificativas para a realização deste trabalho, eis, em linhas gerais, o projeto:

\section{Objeto}

A estética musical, pensada em seu arcabouço disciplinar enquanto filosofia da música. Pressuposto: a estética não é um ramo da filosofia, e sim a filosofia inteira, voltada para os problemas da arte, e no presente caso, para a arte musical.

\section{Objetivo}

Recolocar a filosofia da música no centro de uma discussão conceitual que, a partir de sua própria natureza especulativa, leve à compreensão dos problemas que ela mesma encontra para se legitimar enquanto um campo que possa trazer contribuições substanciais, demonstrando que essa estética, desde o alvorecer do século XX, não pode se manter dissociada de uma dimensão crítica. Tampouco pode se consubstanciar num isolamento em relação às contribuições dos estudos sociológicos, históricos e culturais. Colateralmente, problemas concernentes à especificidade da música com relação às outras artes; a possibilidade de um delineamento epistemológico e metodológico; o estudo de determinados casos que considero paradigmáticos tanto para que se compreenda a situação da música e da filosofia da música como para o lançamento de novas possibilidades para a disciplina, serão levantados. 


\section{Premissas e hipóteses:}

\section{i. Premissa}

A estética musical é uma disciplina com pouca credibilidade. Ela é vítima do pensamento tecnicista que justifica a música somente através das ciências empíricomatemáticas, e a concebe apenas dentro da lógica de um sistema. As epistemologias estão confusas, malgrado a paulatina hiper-epistemologização dos campos na ciência e na arte, de modo que argumentos de um campo justificam os de outro. As disciplinas analíticas, que não sobreviveriam se não levantassem algum problema para o pensamento que não seja unicamente um problema poético-artesanal, vêm substituindo as possibilidades de um pensamento crítico; as ciências humanas tomam a arte como algo indistinto dentre do rol de produções humanas e a obra a partir da ideia de evento cultural.

\section{Hipótese}

É preciso redefinir a estética segundo a possibilidade de um pensamento crítico. $\mathrm{Na}$ impossibilidade de se propor um novo delineamento epistemológico - empresa impossível, e que acarretaria a tentativa de uma obra teórica - o próprio pensamento e exame dos problemas epistemológicos que compreendam os campos específicos de atuação de cada disciplina - já prevendo as possibilidades de relação interdisciplinar contribuirá para uma estética musical alternativa. De fato, é preciso superar parte das disposições canônicas para realinhar as epistemologias em conteúdos relacionais não hierarquizados ${ }^{10}$. Isso, no caso da música, segundo as noções que proponho, passa por concretizar um pensamento estético que seja alternativo à filosofia da música nova de Adorno, que em grande parte conferiu legitimidade à Escola de Schönberg (da qual devem fazer parte seus alunos Webern, Berg e Eisler), latente hoje na maior parte das abordagens sobre música.

\section{ii. Premissa}

A história da filosofia e da música foram condicionadas a uma leitura segundo a ótica idealista platônica. O materialismo latente nas manifestações originais da ovoın่

\footnotetext{
${ }^{10}$ Relacionar uma disciplina com outra para um exame da coisa musical - como história, sociologia etc. a partir de uma ângulo primordial, a filosofia, no caso desta proposta, não deve consubstanciar uma hierarquia onde, a filosofia é mãe de todas as outras. Antes, cada uma deve contribuir na sua especificidade para que melhor se agreguem.
} 
foi sufocado de diversas formas, num longo percurso que leva a música do corpo à mente, cristalizado pelo platonismo e pelo cristianismo. O idealismo afetou também as concepções de arte a partir do século XIX de modo que diversos paradoxos surgiram na própria formação do cânone estético e musical que orientará diversas concepções musicais a partir do século XX.

\section{Hipótese}

Somente uma filosofia que reconheça a sua relação histórica com as disposições canônicas poderá se enxergar como crítica. Para tanto, é preciso reconhecer que há uma latente dicotomia entre formas de idealismo e de materialismo, e que suas imbricações epistemológicas podem muitas vezes contraditórias, porém trata-se de uma dialética necessária. $\mathrm{O}$ reconhecimento dela é condicional à tão almejada relação interdisciplinar que pode um dia acontecer numa renovação da disciplina. Tomarei este binômio mais num sentido metafórico do que expressivo histórico.

\section{iii. Premissa}

O paradoxo e a contradição são as principais marcas do pensamento artístico contemporâneo. A radicalização das posições no século XX geraram inúmeros paradoxos que podem ser verificados tanto numa abordagem da estética musical enquanto campo autônomo de exame das coisas da música quanto nas outras disciplinas pela ótica das quais a música pode ser examinada.

\section{Hipótese}

Os extremos nas poéticas e estéticas geraram inúmeros pontos de toque. Eis que temos um vasto encadeamento de paradoxos quando o extremo de uma posição se achega a aquilo que se nega.

\section{iv. Premissa}

No que diz respeito à arte, é possível verificar longas linhas de tendências ao longo da história do processo de formação da cultura ocidental, que a redefine paulatinamente como uma atividade intelectual, levando-a ao status de categoria aparentemente apartada do labor e do trabalho a partir do século XV. Esse processo de "retirada" (no caso da música já presente em Santo Agostinho) denota, a partir do Renascimento, um processo de autoconsciência da arte em relação ao seu processo 
formativo, de modo que uma tendência à cientifização começa a gradualmente se delinear.

\section{Hipótese}

É uma característica da própria arte o destino à sua autoconsciência? É próprio da obra de arte uma demonstração metalinguística de seu próprio engenho? Assumo que sim. Assim sendo, pretendo verificar diversas tendências da música a partir do século XX por uma nova ótica, uma vez que a questão da poesia da poesia, da arte da arte gerou, na música, efeitos notáveis. O vício das bulas, nas explicações apriorísticas; o que em outras artes ocorre de maneira mais evidente, na música (instrumental, ao menos) pode ser impossível: como mostrar a feitura da música na própria música se ela tem o problema eminente do significado? Isso envolve o problema da música absoluta e outras questões que serão abordadas.

\section{v. Premissa}

Parte do pensamento de Schönberg sobre a preferência de uma "boa doutrina artesanal" a uma "má estética" é definidor do cânone mais efetivo da música contemporânea. Como resultado, os compositores e teóricos que definirão as linhas composicionais no século XX tomam como missão a transmissão e a análise de sistemas composicionais apriorísticos, dando ênfase nas suas doutrinas artesanais.

\section{Hipótese}

Há outro paradoxo ocorrente no pensamento de vanguarda: os compositores que mais levaram a sério a preferência por uma boa doutrina artesanal contribuíram mais no campo do pensamento estético, usada então para a legitimação de suas poéticas, do que no campo da poética. Contradição esta surgida pela própria natureza do "novo" concebida por eles, e sua busca musical pelo caráter irrepetível, pelo não-estilo, pela ruptura.

\section{vi. Premissa}

A tendência tanto poética quanto epistemológica da diluição da estética nas disciplinas das ciências humanas ou das ciências duras ocorre frequentemente a partir da consideração da não existência de uma distinção entre o mundo das coisas e o mundo da arte. 


\section{Hipótese}

Assumir que a arte pode ser vista como uma mera coisa ou como algo transcendente às meras coisas implica na necessidade da assunção de uma definição de arte. Para uma outra ou nova filosofia da música, para uma nova estética, é preciso alinhar a ela uma possibilidade de definição. Por mais que isso seja difícil.

\section{vii. Premissa}

Não é incomum a ocorrência de críticas ao músico-filósofo, por este estar, supostamente, fora da filosofia.

\section{Hipótese}

Assim como os estudiosos e propositores dos paradigmas emergentes para as ciências dos tempos atuais têm proposta a adesão dos métodos mais livres das artes para a remodelação do campo cientifico, talvez, e especialmente no campo da música, o artista possa oferecer à filosofia um olhar diferenciado, quem sabe contribuindo positivamente. Neste sentido, a posição do filósofo que se apropria das artes como objeto para lançar seu pensamento ou do artista que analisa os problemas da arte ou da estética podem ter o mesmo valor.

O que foi exposto até aqui, creio, já promove o panorama no qual se pretende mover o pensamento filosófico no entorno musical e estético, e já demonstra o caráter da abordagem deixando implícito o seu modus operandi. Buscarei abordar essas premissas e discutir essas hipóteses sempre orientado ao objetivo principal: levantar possibilidades para uma outra estética musical, uma vez que a disciplina, no estado como ela é compreendida, padece daquelas 'acusações' que já demonstramos, e que me orientarão e darão sentido a algumas de minhas buscas.

Uma vez definido o modo como ocorrerá o desenvolvimento desta abordagem, sigo para a primeira parte deste trabalho. 
PARTE I

PROBLEMAS EPISTEMOLÓGICOS: POSSIBILIDADES PARA A ESTÉTICA 


\section{PARTE I - Problemas Epistemológicos: Possibilidades para a Estética}

\section{Filósofo, artista.}

É preciso destruir o preconceito, muito difundido, de que a filosofia é algo muito difícil pelo fato de ser a atividade intelectual própria de uma determinada categoria de cientistas especializados ou de filósofos profissionais e sistemáticos. É preciso, portanto, demonstrar preliminarmente que todos os homens são "filósofos", definindo os limites e as características desta "filosofia espontânea", peculiar a "todo o mundo", isto é, da filosofia que está contida: 1) na própria linguagem, que é um conjunto de noções e de conceitos determinados e não, simplesmente, de palavras gramaticalmente vazias de conteúdo; 2) no senso comum e no bom senso; 3 ) na religião popular e, consequentemente, em todo sistema de crenças, superstições, opiniões, modos de ver e de agir que se manifestam naquilo que geralmente se conhece por "folclore" (GRAMSCI, 1999, p.93).

Seria realmente sensato afirmar a necessidade condicional do "pensar música" somente a partir de sua especificidade? Em outras palavras: ao filósofo, ao fazer estética, seria preciso o conhecimento especificamente técnico da arte para que a partir dela possam ser lançados seus postulados? Se assim é, de fato Hawking tem razão: a filosofia morreu e os filósofos para nada servem. Se a condição do filosofar sobre arte requer o domínio da especificidade técnica de cada arte (no caso da música um conhecimento das técnicas de composição, dos sistemas composicionais) seria temerário o lançamento de quaisquer doutrinas do pensar. Todo o campo passível de ser objeto do olhar filosófico tem a sua especificidade e sua técnica, portanto impõe ao pensar a sua limitação ${ }^{11}$. Por outro lado, parece óbvio que a arte, mesmo tomando-a como uma coisa qualquer como as outras - como um produto ou algo de produzido - é um fazer cuja especificidade reside na existência de uma técnica, que sendo mera técnica, não deve desvanecer na sua função, antes, desvanece a fortiori na obra acabada, fazendo com que o material ganhe outra realidade, ou que a ele se agregue outras realidades, ficando a técnica oculta. Pensando desse modo, por assim dizer, de alguma pregnância heideggeriana, a compreensão das técnicas e das doutrinas artesanais que orientam as poéticas artísticas, se não condicionais, são pelo menos enriquecedoras das possibilidades do pensamento, embora o que de mais específico poderia haver na arte

\footnotetext{
${ }^{11}$ Uma lembrança: Cf. Teeteto (Platão): "Sócrates - Estou vendo, amigo, que Teodoro não ajuizou erradamente tua natureza, pois a admiração [eu traduziria como "encantamento"] é a verdadeira característica do filósofo. Não tem outra origem a filosofia”.
} 
residiria em sua autonomia com relação ao mundo das "meras coisas"12. Como alternativa a esse pensamento, a ampla gama de estudos culturais, antropológicos e sociológicos, pode demonstrar que, para além de ser um produto abordável a partir de suas especificidades, as obras de arte - se não desvanecem na sua função - desvanecem em seus campos; isso joga por terra qualquer pretensão de autonomia, relativizando a arte segundo os domínios em que se joga o jogo cultural da qual ela faz parte, que carrega ainda toda a leitura interessada que dela se faz ${ }^{13}$.

Esta questão, que defino como um combate entre autonomia-pregância, por onde se envolvem dialeticamente um binômio idealismo-materialismo, é um dos problemas latentes da estética que estamos discutindo neste trabalho.

Especialmente em Gullar, o dilema autonomia-pregnância se dilui:

se é certo que, em última instância, todo produto cultural é ideológico, não é menos certo que a sua elaboração se faz com certa autonomia, e quando se ignora esse fato, ignora-se o que a arte possui de específico; e caímos nas generalizações sociológicas (GULLAR, p.82, 2006).

De qualquer maneira, a especificidade da produção artística pode ser um obstáculo ao pensamento sobre arte. O equilíbrio no binômio artista-filósofo não é de difícil manutenção, mas só examinando-o e procurando conceituá-lo será possível estabelecer os primeiros passos para a compreensão do papel da estética no mundo hodierno. Porém, antes, é preciso examinar como se dá a imbricação entre a atividade do artista e do filósofo.

A tarefa não é simples. O que está em jogo é o puro pensar conceitos a partir da materialização daquilo que é puro pensar. E, se a arte em questão é a música, o tal problema do equilíbrio filósofo-artista ganha contornos ainda mais dramáticos. A

\footnotetext{
${ }^{12}$ Não por acaso Luigi Pareyson concebeu sua teoria da formatividade após uma observação contínua não de obras, mas de artistas, críticos e intérpretes em pleno labor. Rousseau, Nietzsche, Adorno na música, e Dino Formaggio na escultura, também possuíam o conhecimento artístico especifico.

${ }^{13}$ Neste ponto, é interessante demonstrar o modo como Nicholas Cook, no início do prefácio da monumental The Cambridge History of Twentieth-Century Music, examina as disparidades entre o pensamento dos diversos autores que colaboram nos diversos capítulos, sem, no entanto, esquecer que estes que fazem a história e consagram este ou aquele autor, são os "criadores" de cânones, e apesar de vindos de campos específicos, têm outros graus de homogeneidade: "como se poderia esperar a partir do título, esta é uma história escrita a partir de uma perspectiva geográfica, social e cultural distinta e relativamente homogênea: predominantemente anglo-americana (apesar de existirem dois autores da Alemanha, um da África do Sul e outro da Austrália), mais do sexo masculino do que do sexo feminino (representação de gênero em musicologia, pelo menos no Reino Unido, está longe de ser igual) e branca" (COOK, 2004, p.1). Na resenha do livro O Ofício do Compositor Hoje (2012), uma coletânea de ensaios de diversos compositores brasileiros atuais, o musicólogo e compositor Marcos Câmara de Castro (CÂMARA de CASTRO, 2015) realiza um exame da mesma natureza, deflagrando, preliminarmente a falta de uma conpositora que pudesse ser parte do quadro de escolhidos.
} 
especificidade da arte do som no tempo é a mais inacessível dentre as especificidades técnicas das outras artes. Os jogos a que a arte foi submetida no século XX demonstram que a música pode sair um pouco menos avariada no que diz respeito às possibilidades de total desagregação da obra, sorte que as artes plásticas não tiveram. Assim sendo, parece sensato dizer que ao amador, a música - considerada em suas especificidades foi sempre menos condescendente. Por isso resistiu por mais tempo ao advento da total desagregação da obra, sorte que as artes visuais não tiveram. O dilema se aprofunda, então, para o esteta, normalmente pensado num movimento de fora para dentro, ou seja, do filosófico para o artístico; ou da filosofia para a arte. A filosofia como lente para a compreensão do estado da arte.

Pode-se concluir, então, que o pensar filosoficamente a arte irá pressupor, $a$ priori, essa estrutura dilemática, que se aprofundará ainda mais na era da especialização e da prioridade científica, principalmente a partir do século XX. Pode parecer então que, em nossa era, pensar que as artes são várias, mas a estética é uma só, como um dia postulou o compositor Robert Schumann, seria um contrassenso. Isso explica o aprofundamento das diferenças epistemológicas inerentes às ciências modernas. De fato, mesmo no campo de uma só arte, a música, vemos uma espécie de hiperepistemologização, resultando em vasto número de microcampos que buscam o que de mais específico pode residir na da arte musical. Mas não seria sintomático também, o que ocorre hoje no extremo oposto? Em plena era do específico, no que diz respeito ao campo onde o específico (especialização focada sem maiores necessidades de contexto) se faz mais patente, as sociologias e antropologias da música não pretendem um exame lato sensu da arte, ou seja, paradoxalmente, sem levar em consideração justamente as questões específicas da música ou não stricto sensu? Tirando-a de sua especificidade técnica e reproduzindo os seus efeitos como uma coisa em meio a outras coisas, como um produto humano tomado como qualquer outro produto? Se tomarmos a arte sob este ponto de vista, Schumann não parece ter razão? E ainda, radicalizado? Neste caso seria preciso um campo epistemológico cheio de nuances para um pensamento sobre arte e ela poderia ainda ser objeto do pensamento sob qualquer condição.

Não pretendo me opor a uma ou a outra possibilidade de pensar a música. Antes, pretendo expor uma situação que me parece conscientemente ignorada, malgrado permanecer um problema, pelo menos desde o século XVIII, na alvorada da estética enquanto possibilidade disciplinar. 
Mais do que essa exposição, pretendo demonstrar que, no que diz respeito ao pensamento sobre a obra de arte, mais ainda sobre a música, a radicalização de uma premissa normalmente culmina no seu oposto. Eis o que a modernidade pôde nos legar: a radicalização dos conceitos (aqui no sentido de isolamento agressivo) legou uma cadeia de paradoxos e contradições que de diversas maneiras podem ser revelados.

Se examinarmos, por exemplo, apenas essa oposição entre a necessidade de uma abordagem específica, analítica e técnica, e uma mais geral e especulativa, vemos que ambas podem enfraquecer as possibilidades do pensamento estético se tomadas nesta mesma aguda polarização. $\mathrm{Na}$ verdade, os extremos do rigor epistemológico sobre música no século XX, que puderam levar a pesquisa sobre as obras ao nível da ciência (o que, como veremos mais tarde é apenas uma falsa novidade) através de análises cada vez mais duras e tautológicas, orientadas sempre no sentido de desvendar a estrutura e o modus operandi que supostamente teria levado o compositor à sua síntese e a ereção de seu sistema artesanal, passou a lançar dúvidas sobre possibilidade de análises mais abertas e multidisciplinares, que não se apeguem ao arcabouço estrutural, mas lancem bases para uma compreensão da obra musical enquanto obra do pensamento.

Neste caso, estas análises pretendem se lançar no mundo da construção da obra, da feitura, do têxtil, da possibilidade de desvendar a "equação" por detrás da obra. Este modo de exame pode parecer filho das tendências à cientifização da arte no século XX, e nessa forma de compreensão, o mundo da obra se resume, ou pelo menos se torna acessível, somente a partir de suas doutrinas artesanais. Pensando a partir dessas correntes, se a obra tem mundo, ele reside nas leis matemáticas de sua produção. Por outro lado, completamente oposto, podemos atualmente perceber nas múltiplas recepções das obras uma outra tendência, cuja leitura visa a contestação do cânone, a averiguação do contexto de produção, a pesquisa do entorno, do impacto da obra, da cultura de onde ela emerge, trazendo a um segundo plano a análise do texto pelo texto, da partitura em sua legalidade interna - o que uma sociologia da música deve garantir deixando de lado aquela abarcadora tendência hegeliana e substituindo a noção de obra pela noção de evento ou processo, concebido como o mundo de suas relações com a sociedade, como a rede de apropriações e reapropriações que puderam garantir a sua permanência no repertório, que a fizeram célebre, desvelando as estratégias para essa manutenção - e aqui mundo é sempre uma rede sistêmica, onde são secundários os aspectos inerentes às doutrinas artesanais ou aos significados dados no mundo da 
própria obra, valendo mais o conhecimento das estratégias e apropriações que fizeram com que esse e não outro sistema musical fosse utilizado.

Embora haja uma distância, talvez indesejável, separando essas duas formas de conceber a arte e seu mundo, pode-se dizer que do ponto de vista filosófico, a radicalização dessas posições pode enfraquecer a proposta para uma revitalização da estética concebida enquanto disciplina. Isso ocorre pois, em se tomando radicalmente as tendências do pensamento moderno sobre arte, tendo como pano de fundo as manifestações desagregadoras dadas na arte moderna, o radicalismo do pensamentolimite pôde legar uma cadeia conceitual circular, onde tudo parece desaguar no seu contrário, ou seja, em paradoxos.

Essa já é uma conclusão daquilo que vem sendo constatado ao longo do início deste exame, mas só é conclusivo numa medida mais ou menos abstrata, pois a estes problemas muitas questões serão relacionadas até o fim desta abordagem, propondo relações conceituais não-limítrofes, já que essa cadeia, mesmo numa leitura menos profunda, poderia se dar justamente na não-necessidade de uma estética outra, já que prevaleceria o que já há: uma leitura radicalmente socializante, onde a obra é evento cultural ou uma produção indiferenciada de qualquer outra produção; uma leitura que não leve em conta uma sua especificidade técnica, nem a necessidade de uma epistemologia alinhada com a natureza dessa especificidade, de modo que se possa diferenciá-la de outras produções que seriam eventualmente 'não-artísticas'. Tal leitura, de fato, poderá se manter como um pensamento mais conectado ao mundo do homem, sendo talvez, tendente a um materialismo. Mas, paradoxalmente, tocaria no outro extremo, por exemplo, podendo justificar o idealismo estético da vanguarda: uma vez que nada se diferencia enquanto arte, tudo pode ser arte se é produzido o hecho estético.

Por outro lado, pensar radicalmente a partir de parâmetros idealistas e autonomistas, o que de saída pressupõe necessariamente uma retirada da obra do mundo das meras coisas, pressupondo que a verdade imanente da obra indica a sua grandeza, balizada pela sua total autonomia, singularidade e desconexão com o mundo da cultura, tiraria de cena o sujeito, redundando numa análise da obra a partir de seus valores inextrincáveis - dita l'art pour l'art. Aqui, o hecho estético só poderá ocorrer enquanto $\alpha \lambda \dot{\eta} \theta \varepsilon 1 \alpha$, e a obra, enclausurada no seu próprio mundo, conquistaria sua total autonomia. Ora, se essa autonomia da obra é existente por seus valores inextricáveis, então a obra só poderia se dar nessa recusa da cotidianidade, resultando, como situação-limite, na produção do objeto enclausurado no seu ser-coisa, dando margem à ideia de uma 
autonomia que pressupõe a valorização do objeto pelo objeto, mesmo que se diga que não há distinção entre o sujeito e o objeto.

Na prática, esse idealismo radicalizado resultaria ou num materialismo objetal que dá, no caso da música, margem à diluição do pensamento nas disciplinas duras, ou na busca da ereção do sempre-novo-singular, que também salvaguardaria a posição contraditória da vanguarda, que em algumas das suas linhas pensam o objeto como produtor de mundo, mas contextualizado na busca por um novo absoluto.

Levando a situação mais ainda ao limite, se na possibilidade da total autonomia da obra o enclausuramento do sujeito é produzido pelo enclausuramento do objeto, pensar o desvanecer da relação sujeito-objeto tampouco lograria uma análise apropriada. Se essa relação não existe, pois tudo é Dasein $^{14}$, temos então a possibilidade iminente de um sujeito-obra. Na primeira hipótese, onde o sujeito sociológico produz a coisa, mas esta coisa não é passível de uma transformação simbólica, temos que se nada é arte, tudo é arte. Não há produção diferenciada, basta a produção do hecho estético, aludindo aqui ao dizeres de Borges na epígrafe (ou como no caso da poética da phýsis).

Se por outro lado o objeto se apresenta como possibilidade de transcendência do mundo das meras coisas, e é um mundo produzido de forma diferenciada, temos que a singularidade é uma conditio para o desvelar da verdadeira obra. Então o hecho estético se dará apenas na singularidade da $\alpha \lambda \dot{\eta} \theta \varepsilon 1 \alpha$. Temos então o enclausuramento da obra, e o objeto elevado a si mesmo numa produção de si para si, sempre singular, faz com que o novo se estabeleça como necessidade. Outro malogro: se objeto e sujeito são indiferenciados, então o hecho estético é uma finalidade, pois obra e sujeito produtor da obra não se diferenciam. A obra então é o sujeito; ou seja, a obra não existe ou é desnecessária. Sendo desnecessária só pode se realizar enquanto puro fato estético, pura aisthesis, produzida como choque. Pensando as tendências no limite, teremos então: se o hecho estético se dá de forma indiferenciada não temos obra. Se o hecho estético se dá na singularidade não temos sujeito, só temos o "novo". Se o hecho estético se dá na não existência da dialética sujeito-objeto, só temos choque, não temos obra e nem sujeito.

Essas colocações podem ser tomadas tanto como constatações de importantes problemas da estética, verificada nas situações limites que nos são legadas, quanto já

\footnotetext{
${ }^{14}$ Lembramos que o Dasein (o ser/estar aî), um dos conceitos centrais na filosofia de Martin Heidegger, diz respeito à verdade existencial revelada, a presença ou realidade humana, o ser do homem no mundo. Trata-se daquilo que realmente importa no ser humano inventivo, sua diferença, sua singularidade na linguagem.
} 
postular um quadro introdutório da situação da arte desde o início do século XX, para que já se vislumbre a natureza deste trabalho, e o caminho pretendido para realizá-lo.

De certa forma, investigar a possibilidade de um artista-filósofo tendo em vista este estado de coisas, é já verificar a possibilidade de tentar libertar a estética desses labirintos.

Por ora, estrategicamente, avancemos.

Vê-se que a discussão sobre estas possibilidades de abordagem, e mais do que isso, da possibilidade de pensá-las no limite de suas radicalizações nos levará, de modo incontornável, ao aprofundamento de uma discussão sobre a estrutura dilemática da atividade do esteta, ou do filósofo da arte.

Se para o presente exame é profícuo que tomemos ambos os discursos em suas essências enquanto possibilidade epistemológica, enquanto "campo" distinto norteado por ideologias próprias, será possível deduzir, como já venho fazendo, um modelo de pensamento onde a abordagem dita "científica" das artes, em especial a música, dentre as artes a mais abordável do ponto de vista cientifico, reside nas ferramentas analíticas surgidas especialmente no século $\mathrm{XX}$, e que atualmente prosperam no campo acadêmico, colocando a música, a partir de suas obras, sob a categoria de objeto científico observável.

É assim que, na prática, as análises da música moderna tendem a substituir a estética, onde apenas o especialista procura resolver os problemas teóricos que circundam a obra. Mas a radicalização desses termos, onde se pensa esse campo como a válvula propulsora do pensamento sobre a música, pode ser uma armadilha. Neste caso, pensado no limite de suas possibilidades, que residem no conhecimento técnicocientífico profundo do objeto, aparentemente o exame do filósofo se torna em comparação apenas um exercício esquálido. Não é incomum a estética ser vista desta forma. No caso das categorias disciplinares analíticas, para sua realização, é preciso ser profissional da análise, da teoria. Só especialistas detêm o fazer, o mister da abordagem musical.

Os problemas são sem dúvida mais fáceis de serem resolvidos quando negamos um pensamento mais especulativo em prol de uma análise mais objetiva. É óbvio que esse "mais objetiva" não exclui a inerência especulativa que há em qualquer 
possibilidade do pensar. Mas não se pode negar que uma análise musical baseada, por exemplo, no estruturalismo schenkeriano ou nos pressupostos da teoria dos conjuntos tendem a delimitar o objeto - no caso, a obra musical ou parte dela - dentro daquilo de mais objetivo que ela pode possuir: suas estruturas compositivas concretas, sua feitura; ou, numa linguagem mais semiótica, no texto.

Por outro lado, se na ambiência acadêmica, sempre ávida por ciência, a música parece um objeto mais digno quando examinada dentro desse campo, me parece óbvio que o contrário passa a ser verdadeiro, e se as sociologias e antropologias da música conseguem ainda se manter dentro de parâmetros de legitimidade cientifica, uma vez que trabalham, mesmo em arte, com parâmetros mensuráveis - como comprovou Bourdieu, por exemplo - a possibilidade de uma estética ou de uma filosofia da música parece residir num campo restrito, onde não se produz tanto, não se promove tanto.

Tudo isso parece subsumir a partir de uma espécie de ilegitimidade do filósofo da arte. Afinal, a arte em sua tremenda especificidade técnica pode ser objeto do filósofo sem maiores riscos? Ou talvez ela só deflagre a incapacidade da filosofia na era da especificidade e especialidade? Por outro lado, se ao filósofo é ainda legítimo abordagens sobre a arte - e acredito que seja, mais do que nunca - porque ao músico ou ao artista não se dá a mesma legitimidade ao se apropriar da filosofia para pensar a sua própria arte? Algum filósofo negaria a legitimidade filosófica do pensamento estético de artistas como Ferreira Gullar, Igor Stravinsky, Luciano Berio e Pierre Boulez? E algum artista negaria a legitimidade do pensamento artístico de filósofos da estatura de Luigi Pareyson ou Martin Heidegger?

Parece-me óbvio que essa possibilidade de negação pode, inclusive como artifício ideológico delimitador da legitimidade de campos, desqualificar o pensamento filosófico passível de ser lançado pelo músico ou pelo artista, quando esse não é filósofo 'profissional'. E quando o assunto é arte, tudo se complica. O filósofo pode se apropriar da ciência, dos aspectos sociais, históricos e antropológicos sem que precise necessariamente ser profissional nessas áreas. Mas a quem queira filosofar ou ser esteta, sendo músico, pode encontrar as recorrentes acusações de amadorismo filosófico. Ao fim da querela os dois lados saem perdendo. E no caso da música, ganha por W.O. o 
analista, que pleno em seu campo, acredita dar o que pensar com as análises estruturalistas das partituras, usando suas teorias de estimação ${ }^{15}$.

$\mathrm{Na}$ realidade, tem-se um autêntico quid pro quod, onde as diferenças epistemológicas, malgrado o esforço monumental em mais e mais a distinguirem, tendem, ao contrário, a embaçarem-se confusamente. Seria bom se fosse por uma necessária interdisciplinaridade. Mas não: as fronteiras se embaçam pois a radicalização de suas supostas verdades as aproximam de seus contrários. E o que temos é o atropelo de umas pelas outras. A análise, assim, termina por ocupar a função ou o lugar de uma necessária estética alternativa, de uma nova filosofia da nova arte musical.

Essa ocupação se define, em parte, pela própria natureza dita científica almejada no meio acadêmico. O espaço para o pensamento livre é, doravante, ocupado pelo que se entende como "pesquisa objetiva", como fazer científico. Na modernidade, ao que parece, não há espaços para o pensamento árido e vacilante da filosofia ou das humanidades. No modelo vigente, ciências devem ser baseadas em parâmetros observáveis, pouco variáveis, comprováveis do ponto de vista empírico. Logo, é nas análises musicais - onde o comportamento do objeto é supostamente mais estático onde o desenvolvimento das pesquisas tendem a se concentrar. A estética, prima distante e indesejável, acaba se idealizando e é vista como o campo da especulação; como se a especulação fosse em si algo impróprio. Talvez a ressemantização do termo, sequestrado pelos lobos de Wall Street, tenha contaminado o reconhecimento da real necessidade da especulação [speculum $=$ espelho $=$ reflexão]. Nesta conjuntura, a ciência substitui a filosofia. Poderíamos ignorar esses problemas e qualificá-los segundo uma ótica mais 'pós-moderna', onde uma confusão de conceitos e problemas, que lançados por uma disciplina e acabam por ter a resposta mais razoável noutra, é uma condição, um imperativo dado por um Zeitgeist. O fato é que não se pode negar a existência do problema. Como podemos pensá-lo?

No pantanoso terreno ideológico, onde de fato os campos se acotovelam em busca de suas legitimidades, de sua imposição como canônicos, temos apostado que, a

\footnotetext{
${ }^{15}$ Até pouco tempo, no campo das teorias analíticas da música especialmente nos EUA, os próprios analistas usavam pejorativamente a expressão pet theories para designar o apego de certos profissionais desta área ao uso de determinadas teorias musicais da moda.
} 
continuar como estão, a tendência é que toda estética/filosofia da arte seja tomada pelas ciências humanas ou duras, ambas também em crise. Ou pior, por uma certa ideia do que deve ser a ciência; e, mais preciso, toda ciência terminará por ser toda a estética. Subliminarmente esse pensamento talvez seja o norteador do problemático papel do artista-esteta em face do esteta-filósofo, e de ambos face ao teórico analista, ou do que seria o cientista.

O problema da situação - no sentido mesmo de local, de onde se situa - do pesquisador-filósofo ou do artista-esteta, e em qual modus operandi ele pode ser considerado legítimo, pode ser identificado muito cedo. Justamente no surgimento da estética enquanto disciplina no século XVIII. Examinemos pois, no alvorecer da estética geral, se o problema, como o colocamos, pode estar presente, voltando nossos olhos para o século XVIII, lá onde a estética começa a se organizar em sua autonomia disciplinar. Eis um breve estudo.

\subsection{Problemas no alvorecer da estética}

Se de fato o século XVIII representa um marco na história da estética enquanto disciplina autônoma. Isso se dá quase exclusivamente devido ao aparecimento do termo estética - no caso, primeiro aesthetica e depois die Ästhetik - devidamente vinculado ao pensamento sobre arte, especificamente nas duas obras canônicas de Alexander Baumgarten (1714-1762). No entanto, como tem sido há algum tempo muito discutido, impingir uma abordagem tão generalista que consideraria o século XVIII como época do nascimento da estética, resultaria em seu oposto extremo: uma visão redutiva que excluiria a especificidade do pensamento estético como algo pregnante pelo menos desde a Poética, de Aristóteles. Assim sendo, se o nascimento da expressão estética de fato não resolve o problema do reconhecimento de uma época à qual remontaria o início do pensamento estético, o surgimento de uma linguagem, ou de uma especificação na linguagem, onde uma terminologia que não só aponta o nascimento do termo para designar uma disciplina, mas especificações e preocupações doutrinárias que dizem respeito a formulação de uma epistemologia, me parecem sintomáticas. Pensando assim, o século XVIII não fornece apenas uma terminologia ou tentativa de sistematização para organização daquilo que veio se tornar a disciplina, mas o aparecimento de uma linguagem e de uma terminologia me parecem sintomas importantes de encadeamentos 
históricos que proporcionaram, especificamente no século das luzes, um pensamento estético específico, propiciador de uma estrutura disciplinar posterior.

No que diz respeito a este pensamento, pretendo agora levantar alguns pontos que considero relevantes no sentido do nascimento de uma abordagem disciplinar, e que, no bojo do nascimento da possibilidade de uma percepção filosófica sobre a definição de uma disciplina chamada estética no século XVIII, concebe uma visão peculiar sobre a obra de arte, especialmente a pintura, que resiste, em muitos aspectos, à inclusão de um pensamento similar sobre uma estética da música, especialmente no caso de Immanuel Kant; e é justamente isso que torna o exame necessário.

Três aspectos oriundos em parte do pensamento sobre arte, neste tempo que tenho chamado como o "alvorecer da estética", são oportunos de serem levantados, principalmente devido à manutenção destes ao longo da história da estética, e que ao meu ver podem ter contaminado os ideais em torno do que veio a ser a estética musical.

Neste breve estudo, levanto alguns aspectos do pensamento sobre arte de três filósofos do século XVIII, a saber, Shaftesbury, Diderot e Kant. Embora um pequeno estudo sobre esses filósofos não garanta uma visão precisa sobre as contribuições que podem ser deduzidas do pensamento geral sobre arte do século XVIII, não é de se desprezar que muito da abordagem destes filósofos se apresenta como um recorte dos mais abrangentes em se tratando de estética, mesmo porque partem de tradições distintas, e juntos legam um pensamento importante por estarem no início da organização da disciplina. Ademais, representam a tripartição importante entre a escola inglesa por um lado, e a eterna e dicotômica briga entre campos representado na rivalidade franco-germânica. Será possível notar que se em Kant a pregnância de um idealismo culmina na organização rigorosa de uma epistemologia que impregna a atual noção epistemológica na música, e em parte, e não menos importante, de uma visão que afeta o pensamento musical a partir de um idealismo alemão sempre ansioso por unidade, por outro, o mal-estar em torno do papel do esteta e de seu amadorismo técnico-artístico já aparecem evidentes em Diderot. Shaftesbury, por sua vez, será analisado a partir de sua noção de tablatura, pouco discutida no que diz respeito a uma analogia com a estética musical. 
Neste estudo, será possível abrir já as portas para assuntos que serão discutidos mais ao final da presente abordagem, como por exemplo, sobre como a abordagem kantiana lega problemas ainda permanentes no que diz respeito a uma ideia de música pura. Será possível notar também como, tanto em Kant quanto em Shaftesbury, uma certa ideia do que a arte deve ser leva a um ideal de unidade, que lido a partir das noções de consistência da obra musical, se mantém como um postulado fortemente pregnante em muitos desdobramentos da estética até os dias de hoje.

Com Diderot, confirma-se as impressões que já levantamos no início da abordagem sobre o artista-filósofo, e que cito aqui no intuito de demonstrar como o assunto era urgente já na origem da disciplina estética, e que hoje ainda pode ser discutido no âmbito de uma estética da música.

Por fim, é possível dizer que uma certa inadequação e dificuldade para incluir a música no bojo do pensamento desses filósofos é patente, de modo que certos problemas parecem ainda se manter na contemporaneidade.

Apesar da diferença entre os três filósofos, é possível perceber determinadas convergências, e eleger algumas, que podem justamente facilitar o vínculo com a possibilidade de pensarmos uma estética da música, que, no entanto, apresentará determinados dilemas que a manterá num certo nível de inadequação e marginalização quando comparadas com o desenvolvimento da estética das outras artes. Na história da estética musical isto tem sido muito discutido (desde o século XIX), mas podemos, a partir de alguns pontos de convergência que elegi, quiçá entendermos alguns motivos de uma certa inadequação da música à um pensamento estético mais geral do séc. XVIII.

\section{Três estudo de casos}

Dilemas conceituais: arte-filosofia; unidade e prescrição; poética e estética.

\subsection{Lorde Shaftesbury ${ }^{16}$}

O que pode logo chamar a atenção na possibilidade de uma filosofia da composição em Shaftesbury é justamente a sua concepção de composição (no caso, da obra pictórica), tornada o conceito de tablatura. Não obstante se procure sistematizar um pensamento em torno da obra, me parece possível deduzir da concepção de

\footnotetext{
${ }^{16}$ Todas as referências sobre Shaftesbury são do trabalho A Decisão de Hércules, Anthony A. Cooper, Lorde Shaftesbury; tradução de Luís Nascimento (2012).
} 
tablatura justamente a pregnância de um pensamento, por assim dizer, ansioso por unidade. E este aspecto da composição, que para Shaftesbury é tão mais efetiva quanto mais unidade apresentar na representação, me parece o ponto nodal de sua abordagem. Malgrado a questão moral seja central também na articulação das ideias sobre tablatura, procurarei me ater nesta questão da unidade. Em Sensus Comunis (IV, 3, ed. Liberty Fund., p. 89-90) Shaftesbury postula que a obra é bela e concebe a verdade como vínculo expressivo desta unidade, onde a obra "tem de ser um todo por si mesmo" completo, mesmo que neste todo só haja a possibilidade da representação da parte. Essa concepção onde os "traços particulares (...) têm que aquiescer ao desenho (desígnio geral)" a fim de formar uma "vista simples, clara e unida", aludem diretamente à essência da concepção de Shaftesbury para tablatura, uma vez que a partir do quadro $A$ Decisão de Hércules ${ }^{17}$, dá-se a uma obra particular o nome de tablatura somente quando ela é realmente "uma única peça, compreendida num só olhar, (...) que constitui um verdadeiro todo por mútua e necessária relação de suas partes (...).

Se por si só a ideia de que na obra o belo e o verdadeiro são articulados na necessidade de uma unidade, que deve ser representada mesmo quando a parte é de tal forma carregada da completude das ideias que nela essa unidade que se dá a vista se realiza, é sintomática de uma pregnância clássica que tem sua consubstanciação mais clara na "nobre simplicidade" de Winckelmann; um outro fator colateral que me chama ainda mais a atenção é o caráter prescritivo e normativo da proposta de Shaftesbury, que, me apropriando da distinção estética moderna de Luigi Pareyson, se caracteriza como poética (um fazer, ofício do artista) e não como estética ${ }^{18}$.

Melhor seria dizer que as fronteiras não estavam claras nessa época, como não o são ainda hoje: ora o que se perfaz é uma abordagem eminentemente filosófica sobre a

\footnotetext{
${ }^{17}$ Cooper/Shaftesbury encomendou a pintura O Julgamento de Hércules ao artista Paul de Mattaeis com todas as especificações, ou seja, prescreveu uma obra ao pintor onde ele, filósofo, pudesse exemplificar o seu desígnio de unidade na obra de arte, como exemplo de tablatura. Aqui, novamente, o dilema filósofoartista.

${ }^{18}$ Muito se falará de Luigi Pareyson e sua teoria da formatividade. Sua filosofia e sua teoria distintiva é muito cara para o tecido do presente trabalho. A distinção pareysoniana pode ser apresentada assim: estética: Reflexão geral sobre os fenômenos e a experiência da arte. Trata de categorias como "belo" ou "feio". Não é normativa, não legisla, não postula fórmulas e formas para o fazer artístico. Atua num terreno onde não se pretende a tomada de posição em questões da poética. É essencialmente uma disciplina filosófica, e, portanto, especulativa. É trabalho do filósofo; poética: Conduta normativa na arte, com a proposição de manifestos ou programas, que pode ser tanto de um único artista, como de um grupo de artistas. Postura assumida em meio ao processo criativo em arte. Diz respeito ao fazer material e concreto da arte através da formação de obras. É trabalho do artista (cf. PAREYSON, 1993 e 2001).
} 
arte; ora se trata do postulado de normas para a composição, sobre como é possível veicular o verdadeiro e o belo através da unidade e da moralidade. Essa questão da unidade e da apreensão do uno, apresenta, ao meu ver, uma convergência com Kant, que procurarei desenvolver mais tarde, e que será minha principal hipótese no que diz respeito a dificuldade de Kant com relação a uma estética musical. No entanto, a possibilidade distintiva entre poética e estética (do ponto de vista pareysoniano), a partir da qual eu poderia dizer que Shaftesbury é normativo e prescritivo mais no sentido de uma poética do que em uma estética, é um outro ponto de convergência, desta vez com Diderot, e que serve ao intuito que tenho por ora: o de demonstrar nessa breve exposição, como a presente noção de ciência e estética é caudatária daquela, no início do pensamento disciplinar sobre a arte, e como são latentes, já no alvorecer da disciplina, os mesmo problemas que hoje se apresentam com nodais: o problema da relação do filósofo com as artes (suas especificidades) e o problema central que reside na possibilidade de uma distinção que recupera certa premissa aristotélica, e que reside no binômio estética-poética, que ao fim e ao cabo, é o problema filósofo-artista e suas possibilidades de síntese, afinal, como se dá a imbricação entre quem cuida da estética e quem cuida da poética quando na verdade o pensamento deve ser melhor pensado nas suas possibilidades de interrelação?

\subsection{Denis Diderot}

O plágio que em um verbete (composição) da Enciclopédia de Diderot faz da concepção de composição de Shaftesbury, por si só já demonstra as múltiplas convergências entre os dois. Mas o que há de mais interessante, pelo menos no que diz respeito às minhas intenções nesta especulação, reside em outros aspectos não relacionados à questão da unidade. Se tanto em Shaftesbury quanto em Diderot vemos que a questão da obra enquanto difusora de aspectos morais, consideradas universais, aparece como um valor ideal que a própria obra deve desvelar como inerente - a obra deve "dar o que pensar" (aí onde justamente se concentra a crítica de Diderot ao pintor Watteau) - Diderot parece mais cônscio de seu assistematismo, de sua indefinição em matéria de estética ou poética. Se Shaftesbury prescreve o que seria uma tablatura, de tal maneira normatizada que é proposta a própria obra exemplar consubstanciada no julgamento de Hercules, ou seja, num quase-manifesto propositivo e legislativo em matéria de arte, Diderot, que não chega a tanto, demonstra nos próprios títulos de seus 
escritos o caráter ambíguo de sua abordagem, por um lado especulativa: no Salão de 1775 temos como título "meus pensamentos extravagantes sobre o desenho ou minhas pequenas ideias sobre a cor " etc..

No entanto, o caráter abertamente crítico adotado nos Escritos sobre pintura, revelam este meio caminho entre a estética e a poética, entre ambos e a crítica que aponta a ausência de moral, que poderia ser encarada inclusive como ausência de classicismo no rococó. O que muitos apontam como assistematismo em Diderot, no caso da sua abordagem sobre arte, me parece uma dificuldade em se compreender o papel da filosofia ou do filósofo, ao postular questões sobre arte; uma vez que se não é pintor e nem escultor, Diderot coloca seus pensamentos sobre arte no nível do 'lúdicoextravagante', ou no limite das 'pequenas ideias', enquanto Shaftesbury não se importa em postular um manifesto em forma de obra, que ele mesmo não fez, o que demonstra a tensão artista-filósofo a partir do âmbito da filosofia.

Assim, vemos como este desconforto é imanente à própria estética, mesmo que seus primeiros autores nem estivessem conscientes disso. Obviamente os filósofos gregos, na prática os primeiros estetas, não faziam cerimônias a esse respeito. Basicamente devido não só ao papel social do filósofo na Grécia - mesmo na antiguidade - mas também ao arcabouço filosófico em que a música se inseria. A própria visão posterior de Boécio ainda leva em conta a superioridade dos filósofos em relação aos músicos 'práticos'. A noção multifária de música dos gregos curiosamente munia o filósofo de uma legitimidade que, faça-se justiça, nunca foi dada ao músico de ofício ou ao inventor de outra arte, mas, para os iluministas, aparentemente conotava um incômodo inconsciente. Isso por si só nos levaria a um estudo histórico-filosófico ainda mais aprofundado. Mas para os limites a que me propus, basta este breve estudo para localizar o problema.

No que diz respeito ao que de fato revelaria um assistematismo e uma dificuldade inclusive em inserir Diderot em categorias disciplinares contemporâneas, e ao cruzamento destes pensamentos com os aspectos da estética pareysoniana que temos levantado, surge a possibilidade de aventarmos uma crítica a partir de uma inversão do vetor temporal, e neste sentido podemos pensar a doutrina de Luigi Pareyson a partir de algo que o assistematismo de Diderot dá a pensar: "fui obrigado a fazer tal artigo (composição) - eu que não sou amador nem pintor (...)". Me parece que, a partir dos conteúdos do Salão de 1765 (expressos nos próprios títulos), ou mesmo a partir dessa afirmação, é possível levantarmos especulativamente algo ainda relevante para uma 
estética moderna, onde seja possível o reconhecimento da coexistência nem sempre equilibrada entre um lado mais "amador" e outro mais "profissional", por assim dizer, no ofício do esteta. Segundo Luigi Pareyson,

a estética não é uma parte da filosofia, mas a filosofia inteira enquanto empenhada em refletir sobre os problemas da beleza e da arte, de modo que uma estética não seria tal se, ao enfrentar tais problemas, implicitamente também não enfrentasse todos os outros problemas da filosofia (2001 [1966], p.4).

Ou seja, a questão não reside especificamente na impossibilidade da apreensão das coisas da arte (poética) pelo filósofo tampouco pela apreensão da filosofia (estética) pelo artista. Se como vimos anteriormente

(...) a distinção entre estética e poética é particularmente importante e representa, entre outras coisas, uma preocupação metodológica cuja negligência conduz a resultados lamentáveis. Se nos lembrarmos que a estética tem um caráter filosófico e especulativo enquanto que a poética, pelo contrário, tem um caráter programático e operativo, não deveremos tomar como estética uma doutrina que é, essencialmente, uma poética. Isto é, tomar como conceito de arte aquilo que não quer ou não pode ser senão um determinado programa de arte (ibidem, p.15).

Essa asseveração é tão importante para percebermos que a imbricação necessária dos conceitos poéticos e estéticos sempre estiveram na iminência de uma solução no passado quanto o é ainda para que se possa pensar uma nova estética, e ainda estão no cerne de uma solução para o problema do artista-filósofo. Em suma, para Pareyson, estética é teoria, observação, análise, especulação, enfim, um ofício de filósofo. Já a poética é ofício de artista, que elabora seu projeto e compõe (faz) sua obra.

Mas se por um lado a estética não pode ser considerada uma prerrogativa exclusiva do ofício de filósofo, já que este nem sequer goza de isenção absoluta em ideologia ou matéria de gosto, por outro lado, não só o artista, como também o historiador e mesmo o crítico de arte sempre se encontram inadvertidamente atrelados a uma dimensão estética, à sua capacidade de percepção. As observações e análises de artistas, historiadores e críticos, entre outros, não podem então ser a priori subestimadas. Neste sentido, a distinção conceitual de Pareyson, desde já absolutamente necessária para uma nova formulação, busca dar conta da imbricação a que se submete qualquer artista que pretenda lançar a sua filosofia da arte. Ou a filosofia de sua arte. 
Nesse sentido, se inicialmente Pareyson opta pela solução aparentemente mais fácil, ao considerar todo o pensamento "não-profissional" como "notas esparsas... sem uma reflexão filosófica que as fecunde... [e que] elas próprias ainda não são estética" (ibidem, p.7), é certo que ele indica em que sentido essa imbricação é fecunda:

\begin{abstract}
(...) todos se encontram na estética, cada um trazendo, na tarefa comum, a particular sensibilidade e competência que deriva de sua proveniência pessoal e mentalidade. A estética torna-se assim um frutífero ponto de encontro, um campo no qual tem direito de falar os artistas, os críticos, os amadores, os historiadores, os psicólogos, os filósofos, os metafísicos, com a condição de que todos prestem atenção ao ponto em que experiência e filosofia se tocam, a experiência para estimular e verificar a filosofia, e a filosofia para explicar e fundamentar a experiência (PAREYSON, 2001 [1984], p. 10).
\end{abstract}

Pareyson já apresenta a conclusão, e indica ainda qual é a natureza da estética. Entretanto, na estética musical, podemos colocar a questão assim, com a resposta já dada, mas podendo ser ainda especificada: a condição de um músico leitor de filosofia pode ser julgada a priori como inferior àquela de um filósofo não especializado em música? Não. Em ambos os casos haveria sempre a necessidade do equilíbrio entre um lado mais amador e outro mais profissional. Ao especularmos sobre esta questão, podemos de imediato convergir para a parte final desta abordagem, onde podemos mostrar os pontos de toque entre o que examinamos até agora e alguns postulados da filosofia da arte de Kant, demonstrando, por fim, a dificuldade que o pensamento do século XVIII (no presente recorte) apresenta na adesão de uma estética musical, não só pelas dificuldades específicas desveladas num pensamento sobre a música enquanto arte, mas principalmente - no caso de Kant - naquilo que foi apresentado como um dos elementos essênciais também na filosofia da composição de Shaftesbury: o anseio pela unidade.

\title{
Kant $^{19}$
}

Se em Shaftesbury e Diderot podemos ver convergir tanto questões vinculadas ao problema da transmissão de uma moral, como problemas de unidade e demais aspectos presumivelmente clássicos, que podem talvez ser atribuídos ao advento do rococó, bem como - pensando a partir da abordagem pareysoniana - vermos como uma

\footnotetext{
${ }^{19}$ As referências são em sua totalidade de Vorlesungen über Metaphysik; Curso de Antropologia Parow (1772-1773); Crítica da Razão Pura; Reflexões sobre Antropologia (1776-1778); Crítica do Juízo.
} 
distinção incipiente no interior dos atributos do que seria uma estética embaça as fronteiras do que seria um pensamento menos normativo e mais especulativo, em Kant novamente, como em Shaftesbury, as questões sobre arte parecem submetidas à questões de unidade. Mas desta vez, o por assim dizer, o hiper-sistematismo do filósofo parece engendrar uma forma mais acabada para uma estética em seu arcabouço disciplinar.

Neste sentido, se é possível afirmar que a estética tal como a conhecemos hoje passa pela crítica kantiana, em parte isso parece se dever muito ao fornecimento de uma disposição canônica para um estética filosófica autônoma. No entanto, malgrado o sistematismo kantiano possua a vantagem de já evidenciar as necessidades epistemológicas inerentes a um pensamento sobre arte no seio da filosofia, e dessa forma não padecer de um constrangimento com um suposto lado mais amador - e no caso dos filósofos esse constrangimento reside no não domínio artístico do objeto estético - ela ainda não possui as ferramentas necessárias para abarcar as especificidades da música; e neste caso, não falo aqui das especificidades técnicas, mas filosóficas mesmo. Eu poderia parar este estudo por aqui, uma vez que à questão do filósofo e do artista, julgo, já foram agregadas informações suficientes para a localização do problema ainda na época do nascimento da disciplina. No entanto opto por prosseguir mais um pouco com Kant, uma vez que as dificuldades de adequação da música ao arcabouço geral da filosofia, patentes nesses filósofos, é dramática em Kant. Principalmente quando determinados aspectos ainda se mantêm em vias de discussões mais claras ainda nos dias de hoje.

Ao que parece, é possível notar uma divergência importante, principalmente com relação a Kant e Diderot, que talvez esbarre na própria dicotomia entre as escolas francesa e germânica:

Kant: só é razão quando é sistemático;

Diderot: é preciso fazer violência a esta assimilação; ausência de sistema não significa falta de juízo (preconceito germânico-kantiano);

Ademais, permanece como principal convergência entre os três filósofos estudados, e isso diz muito sobre o pensamento sobre arte no século XVIII, justamente 
o problema da apreensão da obra enquanto possibilidade da percepção de uma unidade, que disposta de forma a dar o que pensar (possuir um sentido moral), ou mesmo - no caso de Diderot - trazer algo da grandiosidade clássica, é ainda apresentada - no caso de Kant - na forma de uma categorização de juízos que asseveram sobre as diversas categorias do processo de apreensão desta unidade. E como veremos, é justamente a questão da possibilidade de expressão de uma unidade - a partir da parte em Shaftesbury e da diversidade em Kant - o que em diversos níveis impossibilita uma estética musical consistente com uma estética geral, muito embora em Kant seja possível perceber como sua estética da pintura é coerente com sua concepção de imagem. Esta é a hipótese que levantamos, e que no século XIX se desdobrará na tentativa de conciliação (a estética de uma arte é a de todas as outras, postula Schumann) na música programática e na ideia de música absoluta.

Assim sendo, exporei a seguir algumas questões sobre unidade que pude deduzir do pensamento de Kant, procurando cruzá-las com o pensamento de outro esteta moderno, Carl Dahlhaus, para quem a grande fragilidade da teoria kantiana reside justamente na sua abordagem sobre a música, e ter em mente determinadas questões ligadas a estes problemas me ajudará a postular outros no decorrer deste trabalho. Lembrando que esta inadequação de uma estética musical no seio do sistema kantiano possui uma vantagem que atina a um arcabouço de revoluções que permanece ainda no século XX e XXI: ela demonstra que, de fato, as peculiaridades da música geralmente resistem aos sistemas e teorias mais gerais da arte, algo, que ao meu ver, o século XIX geralmente não soube reconhecer, mas que, para uma estética que vise pensar os problemas da contemporaneidade, talvez deva ser pensado a partir de uma equilibrada relação: ora um sistema mais geral é necessário para a comparação das artes - sempre no sentido de expor as suas peculiaridades. Ora a especificidade técnica, a fenomenologia da materialidade da obra, sua coisidade específica podem ser um guia mais revelador. É o que estou tentando realizar no presente momento deste texto. O aspecto abordado é quem indica a possibilidade de imbricação. Antes, no entanto, vejamos algo sobre o problema da unidade em Kant.

Ao que parece, o elemento da unidade, em Kant, se dá numa justaposição entre o que a obra fornece enquanto possibilidade de unidade no diverso, e a própria possibilidade de apreensão desta unidade dada na representação; e aqui a possibilidade se dá no sujeito, ou, na própria linguagem kantiana, numa síntese da apreensão na intuição; assim, a unidade é a conditio sine qua non da representação: "pois, enquanto 
contida num instante, toda representação jamais pode ser outra coisa que unidade absoluta". Afinal, no fenômeno da apreensão (não só da obra) "tem de haver (...) algo que torne possível a própria reprodução dos fenômenos, por que ele é o fundamento $a$ priori de uma unidade sintética necessária dela". No caso de Kant, talvez seu pensamento estético esteja subordinado às meticulosas categorias vinculadas ao fenômeno da apreensão do sujeito, mesmo de uma forma, por assim dizer, não sistematizada. Assim sendo, para o pintor, em Kant, há que se "fazer para si do muito um todo ou então ser contra-intuitivo. Daí, ordenação, simetria também nos darem satisfação, como aquilo que facilita a formação de imagem. A posição de cada representação no todo".

De fato, a estética de Kant não trai sua concepção de imagem (na Crítica da Razão Pura), uma vez que o desenho é algo que se dá a ver e, por ser imagem, se dá "em um" na imaginação. A compreensão é facilitada pelo desenho. Imagem e instante (um abrir e fechar de olhos) se relacionam, e seria a própria composição quem permitiria que essa imagem pudesse ser dada num instante, pressupondo aí uma temporalidade, sendo o instante, mesmo dado de forma veloz na apreensão da unidade, algo de não tão imediato. Mas se a concepção estética de Kant abarca uma coerente teoria da imagem e da unidade, algo que o aproxima dos filósofos de outras escolas, como apresentamos aqui, e, principalmente no tocante ao problema da unidade, o insere num sistema estético mais geral e de ecos nos séculos subsequentes, no tocante a uma teoria estética musical, não se pode dizer o mesmo. $\mathrm{O}$ alvorecer da estética já traz consigo o problema da coisidade da música, e a vocação para uma hermenêutica cuja premissa é a unidade, que mais tarde, chamarei como consistência.

Neste ponto de minha reflexão, quando já é possível ver delineado um modelo por onde se possa entender a imbricação filósofo-artista, bem como por onde se pode averiguar que parte do problema nasce com a própria disciplina estética no século XVIII, onde percebemos que determinados problemas surgem exatamente da necessidade de uma compreensão distintiva entre poética e estética, ao meu ver, só devidamente abordada por Luigi Pareyson no século XX, mas que deixa outra em aberto: os limites do filósofo, que residem na especificidade técnica da arte (que temos visto neste breve estudo destes três filósofos, e que, no caso da música, tem maior 
evidencia na abordagem kantiana), face os limites do artista, cuja compreensão filosófica não dependeria de nenhuma especificidade técnica (além de saber ler!).

Neste ponto, após essa recapitulação, penso que é preciso prosseguir um pouco mais com o aspecto da unidade e os limites para uma sua estética musical. Por dois motivos específicos: em primeiro lugar, a dificuldade da absorção de uma estética da música na estética geral de Kant apresenta problemas que, como vimos, se relacionam com a questão artista-filósofo. Em segundo, o problema kantiano com relação à música atina diretamente ao eterno dilema música-texto, uma reprodução ad eternum da querela entre anciens e modernes, ocorrida em muitos momentos da história da música, e que se tornou aguda no século XIX.

Assim sendo, pretendo concluir esse capitulo abordando melhor este tema, para que se clarifique ainda mais alguns aspectos da estética kantiana dentro do que me propus refletir aqui, e para que se estabeleçam bases para estudos posteriores, que notadamente desaguarão no problema do cânone hegemônico dentre as manifestações modernas, o da Segunda Escola de Viena, que estudaremos a partir da segunda parte desse trabalho, ao meu ver caudatário da metafísica musical do romantismo, justamente aquela vinculada à ideia de música absoluta que começamos a tratar aqui.

\title{
3. A ideia de música absoluta como um intermitente problema da estética
}

Convergências: a metafísica do absoluto e a mística pitagórico-platônica; unidade e consistência;

Temos, na Crítica do Juízo:

\begin{abstract}
No entanto, em toda arte bela, o essencial consiste na forma, a qual é adequada para observação e o juízo, onde o prazer é ao mesmo tempo cultura e harmoniza o espírito com as ideias...Se é com estimulação e o movimento do ânimo que se tem a ver, então considerarei a arte dos sons segundo a arte poética. Se ela, de fato, fala mediante puras sensações sem conceitos, por conseguinte, nada deixa ficar, como a poesia, para a reflexão, então ela move o ânimo de forma mais variado e, embora só passageiramente, com maior profundidade; mas é decerto mais fruição do que cultura (...) (KANT apud DAHLHAUS, 2003, p.52-53).
\end{abstract}

Há que se pontuar agora um aspecto histórico que pode auxiliar na compreensão dessa asseveração, que dicotomiza claramente reflexão e puro movimento anímico: de fato, o século XVIII marca a definitiva emancipação da música instrumental. Se a 
música instrumental sempre fora uma realidade na história, toda música, pelo menos até o século XVI, parte de um "idioma" vocal. Mesmo a música composta para execução puramente instrumental. A herança pesada dos postulados da Idade Média, coerente com grande parte do pensamento escolástico, e mais precisamente com o pensamento agostiniano sobre o cantochão, deixa o rastro de um pensamento que considera a voz como a única manifestação adequada em ambiente sagrado, diferenciando a manifestação religiosa da pagã, cujo uso de instrumentos é herdado da tradição helênica e posteriormente "bárbara".

Assim sendo, a paulatina decadência da igreja e do sistema feudal traz consigo o crescimento da importância da música instrumental, numa gradual, mas inexorável dissociação da música das outras artes, que em seu sentido grego mais preciso, eram senão uma só arte. A partir do século XVI a música passa a se libertar dos pressupostos idiomáticos vocais (mesmo a música instrumental é composta a partir de elementos específicos da música vocal), iniciando um processo de emancipação em termos de atribuição de valores: se no século XVII a música instrumental já alcança um alto grau de emancipação, no século XVIII, com o aperfeiçoamento dos diversos gêneros instrumentais esse processo chega a um ponto crítico, onde a valorização da música instrumental iguala sua importância com a vocal na produção dos grandes compositores, como J. S. Bach, e depois os clássicos, quando a sinfonia, o concerto solo, e o quarteto de cordas - notadamente os gêneros de maior fôlego no século XVIII (com exceção da ópera) - promovem uma inversão, um intercambio idiomático, uma vez que a própria música vocal passa a "imitar" a instrumental. Assim, o século XVIII inevitavelmente passa a ter de lidar com um dos maiores problemas da história da música, e que ainda permaneceu por muito tempo como um problema filosófico, sendo ainda nodal numa discussão sobre a possibilidade de uma filosofia da música atual, e que abordaremos sob vária perspectiva em momentos posteriores desse trabalho: o do significado da música quando desatrelada da poesia, do significado de um texto, o que de fato, anuncia o problema imanente da especificidade da música, de sua coisidade, que reside nesta capacidade de fusão (com a dança e com a palavra de forma mais notável), e que levanta a questão da música pura. Esse problema irá se aprofundar no século XIX, quando a estética procura uma saída opondo a música absoluta ou pura à música 
programática, discussão catalisada por Hanslick, tendo forte legado posteriormente nas teorias de Schenker ${ }^{20}$. Segundo Enrico Fubini (2003) a questão da música absoluta é um

(...) problema complexo quer do ponto de vista pratico, quer do ponto de vista teórico e filosófico, que se traduz, em primeiro lugar, num aprofundamento da relação entre duas linguagens, a verbal e a musical - que cada vez mais se configuravam não só diversas mas também antagônicas e, muitas vezes, inconciliáveis: uma é própria da razão, a outra da sensibilidade e do sentimento (...) (FUBINI, 2003, p.113).

E prossegue asseverando que em torno deste tema "delinearam-se os problemas que terão constituído o âmago da estética musical no sentido moderno do termo" (ibidem). Carl Dahlhaus coloca o problema da música absoluta como o paradigma por excelência da estética clássico-romântica, encampando as noções básicas de uma discussão conceitual que pode ser resumida na querela entre formalistas (donde Brahms se destaca) e conteudistas (dentre os compositores engloba Liszt e Wagner como principais ideólogos, mas têm na música programática o seu maior manifesto).

Wackenroder, E. T. A. Hoffmann, G. W. Fink, Schopenhauer e Nietzsche são alguns dos principais veiculadores dos problemas da música absoluta enquanto relacionada com o "inefável", o "poético" e a uma "estética do sentimento", algo que, segundo maiores ou menores contributos, constituí a verdadeira metafísica romântica da música, mas que no fundo, reflete a velha querela entre antigos e modernos. $\mathrm{O}$ compositor Franz Lizst, por exemplo, é bastante abrangente no que diz respeito a uma igualdade de direitos entre a poesia, a música e a pintura, o que dá substância conceitual ao poema sinfônico e outras aplicações da música programática.

Isso pode ser paradoxal no que diz respeito à ampla valorização da ideia de música absoluta, onde a pureza da música seria alcançável a partir de sua 'descontaminação' da palavra ou qualquer outra referência "extra-musical". Mas como nos mostra Dahlhaus, tal ideia tem uma ampla gama de aplicações conceituais, se ressemantizando em conformidade com a produção musical dos compositores. Em outras palavras, como é fácil perceber na história das ideias sobre música, certas

\footnotetext{
${ }^{20}$ Em The Schenker Project (2007) Nicholas Cook tem como objeto o próprio Schenker. Através da análise de abundante documentação, Cook enfatiza especialmente os notórios pronunciamentos sobre a supremacia da raça alemã e o modo como a recepção de suas teorias se relaciona com esse anseio de hegemonia. De fato, teoria e vida não se mantêm a uma distancia segura. Frequentemente elas se estabelecem no sentido de tornar determinadas linhas como mainstream. É nesse sentido que Schenker também estabelece uma forma de análise que visa legitimar uma "segunda onda" de modernistas vienenses, que inclui ainda o próprio Schönberg. Este problema, já antecipado aqui, será melhor analisado a partir da terceira parte deste trabalho.
} 
premissas estéticas surgem para justificar ideias poéticas que pretendem romper com o modo de fazer tradicional, legitimando estes novos fazeres no intuito de torná-los canônicos.

Neste sentido, a estética normalmente é usada como poética. Daí que o amplo estudo de Carl Dahlhaus (1999) é um levantamento não só da recepção da ideia de música absoluta pela estética do século XIX como também um estudo dos paradoxos oriundos do modo como as mesmas ideias basilares se revelam de formas diferentes em querelas infindáveis. No entanto, todo esse arcabouço de cristalizações conceituais parecem residir na oposição entre duas premissas básicas, ambas já circulantes no mesmo âmbito em suas origens gregas: o pensamento pitagórico-platônico, que nos dizeres de Enrico Fubini (2003, p.106) aparece como uma "evocação da natureza da música, das suas leis definíveis em termos matemáticos", e que "representou sempre um movimento vivo na história secular do pensamento musical a partir de Pitágoras"; a

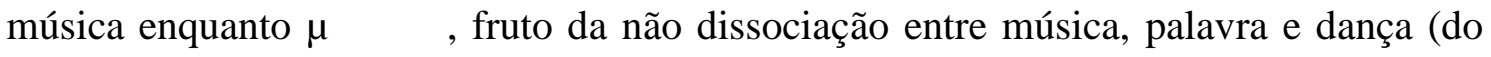
corpo), obviamente lida, especialmente a partir do início do século XVII, como a primazia da monodia.

A ideia de música absoluta pôde se manifestar tanto para justificar posições que a considerassem em sua especificidade, o que foi particularmente o legado de Hanslick quanto, de um lado oposto, justificar o drama musical wagneriano, onde o absoluto ganha uma conotação que não se envolve em uma discussão sobre a música "pura", ou sobre sua semanticidade; na verdade, "absoluto" no sentido de final, de algo que encerra uma percurso, como as amplamente divulgadas ideias wagnerianas deixam claro.

A estrutura dilemática da discussão sobre o semanticidade da música e sua relação com o extra-musical inclui não só uma oposição entre antigos e modernos (que as vezes encerra paradoxos terminológicos), mas uma cadeia maior de oposições como antigo-moderno, estado-igreja, finito-infinito, afeto-nostalgia, ritmo-harmonia, harmonia-melodia (DAHLHAUS, 1999, p.57).

No entanto, é possível identificar a pregnância daqueles dois elementos que já postulamos, e que estão na origem mesmo das concepções e ideias mais antigas sobre música e que, no alvorecer da estética enquanto disciplina, justamente o que estamos estudando, volta a circular. Talvez possamos assim sumarizar o modo como o problema se desencadeia, de sua primeira manifestação mais evidente até o século XIX, quando ele já é teorizado dentro de uma disciplina mais formalizada: 


\begin{tabular}{|c|c|}
\hline \multicolumn{2}{|c|}{ Século XVII (Dahlhaus, 1999, p. 48-49) - Itália } \\
\hline Prima Pratica & Seconda Pratica \\
\hline $\begin{array}{l}\text { Ligada às manifestações da polifonia vocal, } \\
\text { vigente desde Palestrina e, embora } \\
\text { manifesta de forma mais relevante no } \\
\text { âmbito religioso, também parte das } \\
\text { manifestações do madrigal polifônico. } \\
\text { Embora a pratica mais antiga, por isso } \\
\text { prima, nela se manifesta uma ideia mais } \\
\text { moderna com relação à seconda: a da } \\
\text { polifonia. }\end{array}$ & $\begin{array}{l}\text { Ligada à camerata fiorentina e Monteverdi, se } \\
\text { manifesta segundo uma valorização da palavra } \\
\text { em sua relação com a música. É veiculada a partir } \\
\text { do melodrama, tendo como discussão de fundo } \\
\text { um arcaísmo grego mais imaginado do que real, } \\
\text { mas que se orienta em toda uma teoria antiga, } \\
\text { arcaizante da música, malgrado ela tenha se } \\
\text { proposto como o caminho "moderno" com } \\
\text { relação à prima pratica. }\end{array}$ \\
\hline \multicolumn{2}{|c|}{ Século XVIII (alvorecer da estética) } \\
\hline Teór & Teórico \\
\hline $\begin{array}{l}\text { Rameau é emblemático de uma linha } \\
\text { pitagórico-platônica que enxerga na } \\
\text { harmonia a base racional da composição; } \\
\text { "reivindicava energicamente o estatuto de } \\
\text { ciência pela musica, isto é, de linguagem } \\
\text { significativa, analisável pela razão, fundada } \\
\text { em poucos, claros e indubitáveis princípios." } \\
\text { (FUBINI, 2003, p.116). A origem cartesiana } \\
\text { destas premissas trazem à tona a oposição } \\
\text { razão x sensibilidade/sentimento, onde só a } \\
\text { harmonia tem a primazia da razão. }\end{array}$ & $\begin{array}{l}\text { Rousseau encabeça uma linha que } \\
\text { superioridade da monodia, a me } \\
\text { detrimento da harmonia, ainda dent } \\
\text { pensamento arcaizante que consi } \\
\text { indissociabilidade entre música e pal } \\
\text { que tem como discussão de fundo a inf } \\
\text { da música instrumental mediante a su } \\
\text { de moral, de significado. Talvez se e } \\
\text { um pioneirismo em integrar a músic } \\
\text { contexto cultural (FUBINI, 2003, } \\
\text { Dahlhaus, 1999, p.51). }\end{array}$ \\
\hline \multicolumn{2}{|c|}{ Século XIX } \\
\hline $\begin{array}{l}\text { Hanslick encampa um ideal de aproximação } \\
\text { do estudo das artes às ciências naturais. Sua } \\
\text { proposta formalista busca compreender as } \\
\text { artes a partir de sua especificidade material e } \\
\text { técnica, que seriam de fato a própria obra. } \\
\text { No que diz respeito à música, ela é pura } \\
\text { forma, pura significação, sem necessidade de } \\
\text { suportes "extra-musicais". O ideal de música } \\
\text { absoluta alcança com Hanslick uma } \\
\text { elaboração que aponta para uma } \\
\text { compreensão mais moderna da música, } \\
\text { consequentemente, mais moderna da } \\
\text { estética. }\end{array}$ & $\begin{array}{l}\text { Wagner propõe, em seus } \\
\text { ordem estética (manuseand } \\
\text { sua poética) seu ideal n } \\
\text { autoproclamado vinculado } \\
\text { absoluta, o alcança segund } \\
\text { do ideal rousseauniano, onc } \\
\text { uma união entre poesia e } n \\
\text { verdadeira unidade no dra } \\
\text { que isso, o drama musical n } \\
\text { gênero, ele é a "única arte } \\
\text { possível, a arte que reir } \\
\text { artística na sua unidade e to } \\
\text { (FUBINI, 2003, p.127). }\end{array}$ \\
\hline
\end{tabular}

Pode-se dizer, sem assumir tantos riscos, que a estética nasce em um contexto onde séculos de acúmulo de experiências musicais e de ideias e teorias sobre estas experiências vêm à tona em um curto espaço de tempo. Embora se veicule ideias baseadas em paradigmas muito antigos, que remontam mesmo às origens da concepção musical grega, o novo contexto social pós-revolucionário que culmina com o 
nascimento do estado-nação, pode proporcionar uma outra leitura para o alvorecer da disciplina; também para o modo como a ideia do absoluto se consubstanciou em tantas correntes opostas, onde, à parte os pormenores articulados tão profundamente no bojo da filosofia de tantos pensadores, nasce com a disciplina o anseio de manutenção de uma hegemonia, que, se não essencialmente vinculada às ideias sobre música, incide na própria construção das correntes musicais.

Se, como eu propus, há um pano de fundo para todas as discussões, notadamente vinculada ao ressurgimento de ideais pitagórico-platônicos por um lado (onde a primazia de uma razão cartesiana é evidente) e de antigos arcaismos que justificam a primazia da melodia, portanto da sensibilidade, por outro, é certo que todas essas manifestações buscam justificar a música como uma linguagem; linguagem inteligível ou não, completa ou não, superior ou inferior, da razão ou do sentimento. Mas uma linguagem; e autônoma.

É desta forma que no horizonte de criação da disciplina estética, a desconfiança kantiana e rousseaniana que subvalorizam a música instrumental é substituída pela metafísica romântica, que, do aprofundamento da antiga discussão sobre as razões da música e da poesia, se consubstancia numa saída para justificar não só a superioridade da música com relação às outras artes mas, sobretudo, justificar mais tarde um determinado tipo de música em detrimento de todos os outros.

E assim como, embora tenha havido um sem número de pensamentos conflitantes inseridos no contexto do nascimento da estética no século XVIII, pude mostrar a pregnância de alguns pressupostos muito antigos e basilares para todo este pensamento, também é possível demonstrar que, como resultado das discussões sobre o significado da música e seu papel frente às outras artes nas compreensões pioneiras na formação de uma nova disciplina, certos fundamentos permaneceram pregnantes mesmo com o fim do romantismo, legando muito daquilo que temos hoje, não só no muito proclamado crepúsculo da disciplina, mas da arte, ou pelo menos da obra de arte.

Assim sendo, a partir do que expus até aqui, posso postular que o momento do aparecimento da disciplina legou certos problemas, que vistos de forma quase genealógica, podem aparecer assim:

\section{Do ponto de vista da obra de arte:}

A obra de arte se dá na unidade (Kant, Shaftesbury)

A obra deve ter conteúdo moral

A assemanticidade da música é uma desvantagem 


\section{Passando posteriormente às seguintes ideias:}

$>$ A música e a obra podem ser autônomos com relação à conteúdos morais

$>$ A assemanticidade da música é uma vantagem

$>$ Na música reside o "absoluto"

\section{Do ponto de vista da estética musical:}

$>$ A discussão sobre a assemanticidade da música e sua relação com a palavra

$>$ A ideia de música absoluta: a inferioridade ou superioridade da música instrumental

$>$ A aproximação da música aos estudos da ciência

$>$ A dicotomia entre uma visão pitagorico-platônica e uma visão baseada no drama antigo (monodia) - antiga versão grega de música indissociada do logos.

$>\mathrm{O}$ ressurgimento de novas re-significações dadas à antigas querelles.

$>$ A absorção da música pelo recém nascido positivismo científico, que, segundo Fubini, dá origem inclusive a uma sociologia da música.

Naquilo que de fato interessa para que se possa compreender aquilo que ficou, e porque ficou, pregnante da elaboração disciplinar inicial da estética musical, e para que se possa averiguar em que isso atina na formação e compreensão de uma nova possibilidade disciplinar, é possível a seguinte elaboração, com os desdobramentos a seguir.

No alvorecer da estética compreendida enquanto disciplina, pude examinar determinados conceitos inicialmente em três filósofos de escolas diferentes, notando 
que certas ideias lhes eram comuns, especialmente a questão da unidade, que tanto em Shaftesbury em sua concepção de tablatura, quanto em Kant, aparecem como condicionais à uma compreensão filosófica da obra de arte. Em Diderot e Shaftesbury foi possível ver nascer já uma certa inadequação dialética pelo incômodo decorrente do não domínio da dimensão técnica da arte, da especificidade material face às possibilidades de encerrá-la em um domínio filosófico mais amplo. O caso de Shaftesbury, pelas lentes de minha abordagem, pode ser tomado como paradigmático, uma vez que ele encomenda uma obra ao artista de fato no intuito da resolução de sua prescrição poética.

Essa inadequação, por assim dizer, entre a possibilidade de pensar a arte em sua especificidade dentro dos domínios de uma filosofia geral se torna aguda em Kant também, mas - e isso é o que nos interessa em seu caso - se dá justamente em sua abordagem da música quando esta se desnuda em sua especificidade técnica, precisamente na música instrumental; como se pôde ver, embora a estética geral kantiana possa ser especialmente coesa e sistêmica, a música a fere quando o que está em jogo é o que ele compreende como a sua impossibilidade de significação, o que me leva a concluir que de fato a estética nascente padeceu de algumas compreensões que se tornaram recorrentes. Numa delas a especificidade de cada arte, que determina um domínio técnico, legará uma problemática efetiva, que reside na estrutura dilemática da relação filósofo-artista. Esta estrutura indica não só os limites para uma abordagem do filósofo como aponta em direção à possibilidade da legitimidade do artista-pensador ${ }^{21}$, justamente onde reside minha primeira hipótese. A escolha do modo de abordagem por parte do filósofo sempre esbarrará nas possibilidades de compreensão da especificidade técnica do material. Isso valeu para então, e me parece valer para o agora. Outra questão, ao meu ver somente próxima de uma resolução à partir da teoria estética de Pareyson no século XX: a dificuldade conceitual, de convergência disciplinar - portanto que reside numa interdiscipinaridade - entre filosofia e arte, e no caso da música isso se dá de forma ainda mais aguda, pode ser verificada justamente nesta mesma estrutura dilemática; algo que atina diretamente a uma compreensão epistemológica que possa distinguir o que é próprio da arte do que é próprio do pensamento sobre a arte. Ou seja,

\footnotetext{
${ }^{21}$ Basicamente, o século XIX, época em que a estética musical se consubstancia em um corpus mais definido, deixa como herança uma atividade da qual talvez eu mesmo seja tributário. Se pensarmos em Beethoven, Wagner, Lizt, Schumman, entre muitos outros, vemos que a estética musical se concretiza especialmente a partir de compositores-estetas o que, carentes de uma distinção como a de Pareyson, legou mais vícios do que virtudes.
} 
parte dos problemas da estética quando em vias de sua elaboração disciplinar se encontra nesta indistinção.

Os próprios desdobramentos seguintes da disciplina demonstram isso, especialmente no que diz respeito ao modo como a estética musical caminhou durante o século XIX. Pudemos ver que nestes desdobramentos o paradigma dominante da estética musical girou em torno do problema da relação entre música e texto, na imbricação entre a arte musical e a poesia. Se o modo embrionário com que as primeiras experiências com o pensamento estético - especialmente sobre música - puderam desaguar numa avalanche de querelles e discussões conceituais em que as artes se viram envolvidas no século XIX, a música, então no centro das discussões, seria o objeto por excelência, ao meu ver por alguns motivos que transcendem os comumente postulados: a música é mais diretamente apreensível por uma estética do sentimento, mas também é a mais interessante do ponto de vista de uma posterior averiguação "científica", já que seus parâmetros são observáveis a partir de uma lógica empírico-matemática. Isso trouxe à tona toda uma base pitagórica, pregnante especialmente em Rameau. O pode se mostrar como aparentemente paradoxal é que há, logo no nascimento da disciplina, essa "inadequação" residente na relação estrutural filósofo-artista, mas que no caso da música se pode averiguar que a inadequação reside na confusão estética-poética, já que um grande número de compositores são responsáveis justamente pelo pensamento estético-músical do período.

De fato, grande parte do modo como se aborda o problema da música absoluta é resultante de dialéticas onde se reproduzem certos problemas de base para cuja compreensão é necessário determinado acesso aos parâmetros técnicos, além dos filosóficos, atinentes ao pensamento sobre a diferença material entre música e poesia.

Se muitas vezes os filósofos defenderam a ideia de música absoluta em trincheiras opostas, veiculando por vezes de forma obscura os mesmos conceitos (cf. DAHLHAUS, 1999), é porque no âmago da problemática está uma indistinção entre a dimensão poética e a dimensão estética, entre a dimensão ideal e a dimensão material.

A estética aparece desta forma como uma justificativa para a defesa de determinado postulado, o que a coloca mais precisamente como prescrição em matéria de arte do que como um pensamento filosófico sobre o problema. É o que pudemos examinar em Wagner ou mesmo em Hanslick.

O que fica patente e é sintomático, é que tão logo a estética musical começa a ganhar corpo o seu paradigma seja justamente a noção de absoluto, o que como vimos, 
não se resume ao problema da música pura, instrumental. Nas diversas noções veiculadas ao longo da aderência da ideia de absoluto à música - e foram muitas, trazidas por pensadores que inclusive compreendiam a música de forma antagônica podemos notar que, para além de uma discussão de base onde velhos conceitos que ressurgiram do bojo mais originário da música se corresponderiam ao espírito da época, o que surge é uma noção teleológica da música, onde absoluto não se atrela somente a uma dimensão material e técnica (como são normalmente compreendidos os postulados de Hanslick) ou de uma dimensão ideológica (como em Hoffmann, Lizst ou Wagner).

De fato, trata-se, em qualquer dos casos, de uma metafísica que, atrelada ou não a uma estética do sentimento, se mantém pregnante mesmo em sua versão formalista: se por um lado a tendência formalista lida em Hanslick é um primeiro passo para a ultrapassagem de determinadas ideias arcaizantes presentes na estética do sentimento e nas doutrinas rousseaunianas e wagnerianas, buscando superar o corpus essencial da metafísica romântica ${ }^{22}$, por outro, a noção pregnante do absoluto ainda se mantêm; trata-se apenas de subscrevê-la sob o manto pitagórico-platônico para termos o caminho para uma ressignificação da mesma metafísica, mas com um corpus ligeiramente modificado.

Essa prorrogação das concepções estéticas românticas se dão talvez pela manutenção de três elementos fundamentais: a) a noção de unidade, presente logo no alvorecer da estética (e aquilo que se convencionou chamar como "ideia estética" em Kant) que irá se ressignificar e se fundir com b) uma noção formalista do absoluto, que desaguará, como é sabido, na Musikwissenschaft, uma forma ressignificada de pitagorismo, que lhe dará suporte c) as ideias residuais do absoluto da corrente oposta, que tem como pano de fundo uma teleologia que passou paulatinamente a enxergar uma linha poética sincrônica e evolutiva a partir de J. S. Bach, cujo zênite (o absoluto) ocorreria primeiro em Beethoven, sendo reivindicado depois por R. Wagner a partir de seu drama musical.

Ora, não teríamos então todas as condições para que a estética romântica, em vias de sua superação, desaguasse numa ciência da música cujo pressuposto fundamental é uma nova forma de pitagorismo especialmente ligado à uma hermenêutica da unidade? E mais: concebida na ideia da consistência de um caminho sincrônico e genealógico ideal a partir da perspectiva da música austro-germânica?

\footnotetext{
${ }^{22}$ Esta que busca superar uma concepção clássica onde a música e logos são uma unidade, redundando, paradoxalmente no drama musical wagneriano.
} 
É certo que estas constatações podem facilmente encontrar na própria natureza do desenvolvimento dos ideais românticos, como estando ligados especialmente ao idealismo alemão, a sua justificativa, mas esta muito propalada relação é apenas uma das camadas do problema. Se de fato os principais postulados românticos no que diz respeito às artes e ao pensamento sobre as artes são caudatários de um latente espírito revolucionário que veicula nacionalismos recém-nascidos, ideias de organicidade, unidade, origem, dentre muitas que surgem no seio da nova situação política de parte das nações europeias, é certo que no campo dos desdobramentos técnicos da composição musical a partir do século XIX, a atitude geral dos compositores (e isso não inclui somente os compositores alemães, italianos e franceses, mas todo o espectro que inclui desde os russos, passando por Chopin e Grieg) passa por uma determinada encruzilhada no que diz respeito às formas musicais.

As necessidades de tratamento mais livre com relação às formas fixas, especialmente a forma-sonata, tão hegemônicas no que diz respeito à muito mais homogênica "escola clássica", parecem ter acolhido um caminho via busca da unidade na música. $\mathrm{Na}$ ausência da forma, qual seria o padrão organizador das obras em um ambiente onde a música é a "linguagem entre as linguagens" e a música instrumental passa a ocupar um lugar central na estética musical?

Embora seja muito difícil estabelecer uma relação causal - como em toda abordagem filosófica, causa e efeito são ao mesmo tempo - de como certas ideias oriundas do ambiente político e social influenciariam, e em que medida, a composição musical, me parece que o próprio desenvolvimento das técnicas artesanais e dos parâmetros compositivos, sem a pretensão de isolá-los das condições contextuais, buscam um elemento de unidade que pudesse proporcionar consistência à obra musical. Especialmente quando se trata de música instrumental.

Malgrado possa-se ler inclusive a história da música ocidental como uma história da busca pela síntese e pela unidade ${ }^{23}$, e se tomarmos isso como pelo menos parcialmente verdadeiro, a situação da música no século XIX é a de radicalização da busca de substitutivos. A idée fixe (em Berlioz), a metamorfose temática e o leitmotiv (respectivamente em Liszt e Wagner) são algumas das tentativas de encontrar um modus

\footnotetext{
${ }^{23}$ As hermenêuticas mais pregnantes na musicologia não tratariam assim a história da composição ocidental? Do uso distorcido de um cantochão usado como base da polifonia ao uso da isorritmia na Ars Nova, passando ao desenvolvimento da imitação e sua aplicação enquanto sistema no Renascimento, o tratamento retórico-temático no período barroco, a hiper-formalização temática no classicismo. Lê-se a história a partir da noção de uma busca-tentativa de encontrar consistência a partir de unidades temáticoharmonicas, algo que se substancia, segundo minha hipótese, a partir da estética romântica.
} 
operandi que pudesse garantir a unidade face à dissolução das formas tradicionais. Por outro lado, os adeptos do formalismo, como Brahms, radicalizam o uso das formas existentes no intuito de garantir essa mesma consistência e unidade.

A imbricação de todo o pensamento estético do século XVIII e XIX - que como vimos deixa como herança uma ótica da unidade e uma teleologia como formuladores de uma nova ciência da música e uma nova metafísica musical, e não seria demais dizer que uma e outra serão, no século XX, uma só coisa - com o que se produziu em termos de obras musicais nesta mesma época, permite, creio eu, ver o nascimento desta nova (que é velha) metafísica como algo calcado no que chamarei de hermenêutica da consistência ${ }^{24}$. Esse conceito, fundamental para a minha abordagem, serve agora como conectivo para minhas considerações parcialmente conclusivas sobre o que foi examinado até aqui.

\section{Algumas conclusões e aplicações para um pensamento atual: a concretização de uma hermenêutica da consistência}

Quando Ferruccio Busoni expõe em seu Entwurf einer neuen Ästhetik der Tonkunst $^{25}$ (1906) sua compreensão sobre o que seria a música absoluta - "esta música deveria chamar-se arquitetônica, simétrica, ou organizada" - me parece claro que os postulados de uma arquitetônica da música, calcada na sua efetividade material e organizacional enquanto arte autônoma, se substancia como a lógica de uma hermenêutica da consistência. Ao passo que esta lógica aparentemente supera as concepções do absoluto em música ligadas às estéticas do sentimento, ela mantém intacta a ideia de que a música deve ser compreendida a partir de sua legalidade interna, de suas relações de simetria, uma vez que ela é, enfim, cosa mentale.

Sem dúvida estão criadas todas as condições para o nascimento das estruturas canônicas da música no século XX. A pregnância desta noção de arquitetônica poderá reger tanto o objetivismo musical de determinada fase de Stravinsky como permanecerá como um guia concreto por onde se apoia a música austrogermânica, até que ela consiga, de fato, atingir a finalidade de uma teleologia que lhe garanta "100 anos" de hegemonia.

\footnotetext{
${ }^{24}$ Theodor Adorno será responsável por legitimar, do ponto de vista filosófico esta consistência, o que foi um caminho para a consagração do cânone da Segunda Escola de Viena a partir de sua Filosofia da Música Nova (2011[1958])

${ }^{25}$ Esboço de uma nova estética da arte musical (apud DAHLHAUS, 1999, p.39).
} 
A desagregação do sistema tonal e das formas fixas no final do século XIX pôde trazer um legado de busca por caminhos que culminaram numa eleição do mainstream, não por acaso, por vias de valorização da música a partir da sua consistência, de sua arquitetônica, das relações matemáticas regentes de seu sistema artesanal.

Em meio a todas as discussões e debates sobre os caminhos da arte no século $\mathrm{XX}$, no que diz respeito à música, o advento das fórmulas seriais de Schönberg e seus seguidores mais notáveis, como Webern e Berg, inicia um ciclo que, tendo em vista as imbricações entre a produção artística e a produção de textos sobre arte, deu suporte às formulações epistemológicas mais modernas do campo da música, onde a própria estética musical perderá terreno para uma ciência da música que valorizará a unidade e a arquitetura musicais em detrimento de uma filosofia musical.

A desagregação dos valores do pensamento na música é a desagregação da própria disciplina estética. O ponto culminante das ideologias do estado-nação, tendentes no início do século $\mathrm{XX}$ aos fascismos, são parte do mesmo problema do clamor por uma via principal. Uma leitura do (não por acaso) paradigmático, Harmonia, de Schönberg, ou do estudo que Nicholas Cook realiza sobre Schenker não deixa dúvidas quanto ao que estava em jogo: as condições intelectuais e materiais apontaram para a necessidade de um caminho que desse consistência à música no século XX.

Se a Segunda Escola de Viena reclamou para si a vanguarda da música, Adorno irá, no campo do pensamento, ratificar esta tentativa com a sua Filosofia da Música Nova. De fato, o "absoluto", aqui, sai do campo da investigação sobre o significado, e entra no campo da distinção e da emancipação. A filosofia de Adorno e sua via Verbindlichkeit vai de encontro e justifica a escola de Schönberg a partir da noção de emancipação. O absoluto tem agora a sua face aritmética e sua face social, se desintegrando enquanto pensamento estético (talvez mesmo por conta de relações nacionalistas, uma vez que Schönberg é germânico e Stravinsky eslavo). Ao que parece, mais tarde, esse problema do absoluto na música pós-vanguarda foi deslocado e pulverizado em diversas tendências, resultando em algumas narrativas totalizantes mais ou menos hegemônicas. Os compositores da música de concerto, principalmente ligados ao mainstream, não têm necessidade, fora da garantia de consistência, de pensar em termos de significado. Não foi a natureza da música que mudou. O que mudou, foi a noção de significado.

Se em outras artes a desagregação pôde ser muito mais radical do que na música, penso que é porque a noção de significado fora sempre um fator fixo pra essas outras 
artes, enquanto que um valor móvel para a música. A unidade e o significado, seja nas artes plástico-visuais ou nas literárias, foram sempre mais rapidamente apreendidos pela consciência no ato da aisthesis, na ocorrência do fato estético.

Na música, a partir da desintegração da disciplina, o que temos é que o problema do significado da música "absoluta" simplesmente deixa de ser uma necessidade aparente no campo filosófico. Ele residirá agora em outros campos epistemológicos, como a psicologia e a cognição; serão mais valorizadas as relações lógico-matemáticas de uma arquitetônica baseada em teorias apriorísticas do que nesta natureza amalgamante da música, capaz de se agregar à outras artes de forma tão orgânica.

O problema do significado da música quando desatrelada da poesia ou de qualquer texto, embora não mais discutido num âmbito filosófico com a veemência anterior, deixa um legado à disciplina estética que é patente até os dias de hoje, e por isso mereceu atenção no presente escrito: o problema do significado da música "pura", reproduzido a partir de inúmeras querelles, que por sua vez apontaram sempre para problemas estéticos muito antigos, passou de principal problema filosófico-musical no século XVIII, no alvorecer da estética - o que como vimos encerra mesmo um problema epistemológico em $\mathrm{Kant}^{26}$ - a paradigma emergente no século XIX, quando compositores e filósofos deram à música um status nunca antes por ela gozado: linguagem autônoma, linguagem dentre as linguagens, absoluta. Sua assemanticidade e indeterminação passa a denotar sua superioridade em relação às outras artes, o que não "corrigiu" de fato a problemática epistemológica do século anterior; antes, aprofundoua: se podemos verificar no século XVIII o problema da relação artista-filósofo como uma inadequação do problema técnico da arte em sistemas mais gerais do pensamento, e se, especialmente na música pura, entendida como música instrumental, temos que sua indeterminação gera um problema de apreensão de sua unidade e de conceitos morais,

\footnotetext{
${ }^{26}$ Sobre isso, talvez ainda se possa lembrar que as dificuldades que ele encontra em incluir uma estética musical consistente com seu pensamento estético mais geral, tem relação com o postulado de primazia da razão, que repelirá inexoravelmente a "ausência de significado da música". Ainda mais se pensarmos que Kant "nega" a qualidade oculta (eu só entendo o que eu sei fazer). Dahlhaus deflagra justamente que, em Kant, é atribuído à música uma complexa dialética interna: justamente por não se apoiar em um programa, a música instrumental é genuína; mas é inferior artisticamente por ser auto-referencial, não harmonizando o espírito com as ideias, sendo mais fruição do que cultura racional. Se agregada ao texto poético, deixa de ser genuinamente música, mas se eleva à cultura. Ou seja, só é bela arte se servir de veículo à poesia. Obviamente, não somente o problema do significado é nodal aqui. Lembremos que na Crítica do Juízo o projeto de Kant consiste em contrastar o belo ao agradável, o que reforça a dicotomização que ele realiza com relação à música.
} 
esses problemas que são de eminência organizacional da disciplina, e por que não dizer, epistemológicos, se aprofundam quando, na esteira de uma virada conceitual, essa mesma indeterminação semântica da música passa a ser tomada pelo pensamento como o ponto culminante de uma teleologia, o que provoca na estética recém nascida uma virada equivalente.

De um inicial incômodo residente no ajuste entre uma abordagem técnica e outra filosófica no seio de tentativas de organização disciplinar, passa-se à totalização de uma abordagem do absoluto em música não distintiva entre o parâmetro filosófico e o técnico-artístico, afinal, a música estaria acima desta distinção. No século XIX filósofos e músicos se tornam ideólogos de uma estética prescritiva, que lega uma confusão conceitual só abordada com justiça no século XX, quando Pareyson examina a natureza distinta da estética e da poética, do oficio do filósofo e do artista.

Se o pensamento romântico empresta um caráter legitimador à estética, que serve à formação de cânones pregnantes até os tempos atuais, é certo que os efeitos destas legitimações, oriundas justamente das confusões conceituais entre o que seria próprio do pensamento sobre música e da música em si, deixaram legados inquestionáveis: à explosão epistemológica do pensamento sobre música no século XX, agora encampado pelo positivismo, pela sociologia e enfim pela musicologia e suas subdivisões, se pode contrapor a elaboração de uma nova metafísica, que não é nada mais do que a reformulação de uma velha metafísica da música; esta que mantêm intactos a condicionalidade da unidade e da consistência justamente numa releitura dos valores pitagórico-platônicos retidos via formalismo de Hanslick. Esse advento de uma ciência da música trás consigo toda uma tentativa de dignificação da obra de arte a partir de postulados verificativos de sua legalidade interna, sempre a partir de uma ótica empírico-matemática $^{27}$, que eu convencionei chamar como hermenêutica $d a$ consistência.

Como os desenvolvimentos do objeto estão intrinsecamente conectados com o desenvolvimento da observação, dos meios de observação e do observador, e ambos com o seu contexto histórico-social, é certo que, se a estética do pensamento romântico é uma teleologia cuja finalidade é, na música, a formação de um cânone de matriz austrogermânica; e se a lógica da consistência, que se dá a partir de imperativos

\footnotetext{
${ }^{27}$ Este é um problema que se verifica na raiz da crise atual de todas as ciências humanas. Hilton Japiassu (2012) dedica um estudo de grande fôlego ao problemas gerados por esta crise, algo que abordarei adiante.
} 
empírico-matemáticos, passa a ser a substância dos postulados artísticos e dos sistemas artesanais desta matriz, especialmente a partir da formulação serial dodecafônica; é conseqüente que o pensamento sobre música caminhe pari passu com todas essas mudanças, e adira a essa lógica. É desta forma que, paulatinamente, as disciplinas se fragmentam e passam a refletir dois fenômenos: a valorização de uma boa doutrina artesanal às vezes em detrimento de uma boa estética (Schönberg) e o positivismo como base filosófica e modus operandi de todas as ciências, inclusive as humanas. Esses fenômenos não só subscreveram a filosofia e as ciências humanas ao segundo plano como afetaram inclusive o conteúdo delas. Em decorrência desta situação, as teorias analíticas passaram a se corresponder melhor ao ideário artístico das correntes hegemônicas, cujo autoproclamado epíteto de vanguarda parecem cumprir os "100 anos" profetizados por Arnold Schönberg na teoria, mas não num sentido práticopoético.

Assim sendo, o que temos, a partir deste exame, é a formulação das condições para que, hoje, a estética pudesse sofrer as acusações que Talon-Hugon levanta, e que apresentamos no início deste trabalho ${ }^{28}$.

Por fim, me permito concluir que parte da resposta para uma possível reformulação e um necessário recredenciamento da disciplina estética passa pela absorção da experiência do artista pela filosofia. Apesar de demonstrados os malogros iniciais da estética causados pela prática do artista-filósofo, por outro lado, desde que Luigi Pareyson pôde trazer à lume a experiência artística ao seio da atividade filosófica do esteta com a sua Teoria della Formatività, me parece cabível que as possíveis contribuições do artista-filósofo podem apontar caminhos interessantes para o pensar filosófico das artes.

\footnotetext{
${ }^{28}$ Para que rememoremos: a) diz-se que o esteta não sabe o que fala e invoca a arte precisamente por não conhecer as artes; b) o esteta frequentemente "não vê" as circunstancias sociais e históricas da produção artística, numa crença na absoluta autonomia e autocompletude da obra. c) o discurso estético também é acusado "de ser um discurso metafísico aplicado à arte, uma reflexão que não parte da arte e das obras, mas de uma certa ideia do que a arte deve ser". Censura-se assim, na estética, o discurso especulativo metafísico e vazio; d) a multiplicação (sem dúvida epistemológica) das aproximações às artes operadas pelas ciências humanas significa a dissolução do campo da estética nas outras ciências, que abrangem nos últimos tempos a psicologia, a psicanálise e as ciências cognitivas. E aqui, a estética da música, por sua própria natureza tende a diluir-se nas possibilidades teórico-analíticas; e) o discurso filosófico sobre a arte é ilegítimo: contesta-se à estética o estatuto de ciência rigorosa, "a pretexto de que seus objetos têm um caráter subjetivo" (cf. TALON-HUGON, 2008, p. 94-95).
} 


\title{
4.1 No que diz respeito a uma organização disciplinar
}

Talvez passe por aí uma reconfiguração epistemológica que, como afirma Olga Pombo, deve passar por algumas etapas e ser consubstancial à natureza do objeto:

\begin{abstract}
Quando estivéssemos a falar de pluridisciplinaridade ou de multidisciplinaridade, estaríamos a pensar naquele primeiro nível que implica pôr em paralelo, estabelecer algum mínimo de coordenação. A interdisicplinaridade, pelo seu lado, já exigiria uma convergência de pontos de vista. Quanto à transdisciplinaridade, ela remeteria para qualquer coisa da ordem da fusão unificadora, solução final que, conforme as circunstâncias concretas e o campo específico de aplicação, pode ser desejável ou não (POMBO, 2003, p.3).
\end{abstract}

Minha leitura é que estamos ainda nos primeiros dois estágios. Boa Ventura Sousa Santos e Edgar Morin deixam em aberto as possibilidades de relação entre disciplinas para um pensamento complexo que dê conta da configuração complexa do mundo moderno (que para as artes seria o mundo pós-vanguarda): adotar a natureza metodológica das artes para a ciências, a invenção ou criatividade!

Trata-se então de virar o jogo. Considerar o artista-filósofo tão legítimo quanto o filósofo pensador de arte, me parece o primeiro passo para um realinhamento. Temos, através das possibilidades de abordagem interdisciplinar, condições de não tomarmos caminhos que passem pela constituição de novas metafísicas; temos óticas sociais, culturais e cientificas bem delineadas para que o pensador de arte mantenha o pés no chão, no mundo. Temos hoje distanciamento para a crítica do cânone. Temos hoje condições críticas para o realinhamento disciplinar. E temos a preciosa contribuição da distinção pareysoniana, um primeiro e importante passo para a que a estética da música reassuma um lugar no pensamento: livre das amarras aristocráticas, livre da metafísica romântica, livre da metafísica da consistência. A estética pode ser finalmente o lugar do social. Desde que este social respeite essa coisa distinta que a música pode ser, como vimos nessa abordagem. De fato, inevitavelmente a estética da música esteve refém de uma hipótese idealista desde seu nascimento enquanto disciplina. Poderíamos ser tentados a pensar que o formalismo hanslickiano teria sido um passo rumo a uma abordagem que pudesse superar este idealismo ao centralizar o caráter da forma na música, ou seja, de arte enquanto emanação do material.

Mas vimos também que esse postulado, assim como o positivismo de onde nascem as noções sociológicas, foram falsas superações, só levando à criação de novas 
metafísicas. De tal modo isto se deu que a consistência do material da composição pode se tornar uma metafísica ainda mais poderosa e o formalismo, que ao libertar a música de uma estética do sentimento, resultou numa noção de l'art pour l'art e de ciência da música, em apenas outra versão idealista.

Como poderíamos então aprofundarmos este realinhamento epistemológico que pudesse superar essas pré-condições canônicas? Mais: quais os caminhos para que esta realização não desperdice toda a contribuição que o idealismo pode nos legar na incorporação de pressupostos materiais mais exatos? É o que tentarei examinar a seguir com base nessas conclusões prévias.

Daquilo que examinamos até aqui, buscarei em momento oportuno trazer considerações e reflexões sobre as possibilidades de pensar essa natureza peculiar da música, resultante de sua singular característica amalgamante e de sua excelência enquanto arte do tempo, o que, se deveras deu origem a uma metafísica do absoluto e da consistência lógico-matemática, talvez possa ser pensado hoje de modo não consubstancial a uma hermenêutica da consistência.

Penso que, dadas as bases, devamos passar agora a um exame mais profundo sobre certas dicotomias já apresentadas até agora e que, tratadas dialeticamente, talvez nos leve ao âmago dos problemas para uma renovação estética: o problema da fragmentação da estética em formas variadas, o que pressupõe uma leitura filosófica; uma reflexão sobre as possibilidades limítrofes de intersecção entre ciência e música, o que pressupõe uma discussão conceitual. 


\section{PARTE II}

A ESTÉtiCA, A TEORIA MUSICAL, E A SO(M)BRA DA CIÊNCIA: POSSIBILIDADES EPISTEMOLÓGICAS PARA UMA ESTÉTICA CONTEMPORÂNEA 


\title{
PARTE II - A estética, a teoria musical, e a so(m)bra da ciência: possibilidades epistemológicas para uma estética contemporânea
}

\section{Del rigor en la ciencia}

\begin{abstract}
En aquel imperio, el Arte de la Cartografía logró tal Perfección que el mapa de una sola Provincia ocupaba toda una Ciudad, y el mapa del Imperio, toda una Provincia. Con el tiempo, esos Mapas Desmesurados no satisficieron y los Colegios de Cartógrafos levantaron un Mapa del Imperio, que tenía el tamaño del Imperio y coincidía puntualmente con él. Menos Adictas al Estudio de la Cartografía, las Generaciones Siguientes entendieron que ese dilatado Mapa era Inútil y no sin Impiedad lo entregaron a las Inclemencias del Sol y de los Inviernos. En los desiertos del Oeste perduran despedazadas Ruinas del Mapa, habitadas por Animales y por Mendigos; en todo el País no hay otra reliquia de las Disciplinas Geográficas.
\end{abstract}

SUÁREZ MIRANDA: Viajes de Varones prudentes, libro cuarto, cap. XIV, Lérida, 1658

O relato de Suárez Miranda, pertencente ao remoto século XVII e resgatado por Jorge Luis Borges (1998 [1960]), não poderia ser mais atual. Menos por uma sua qualidade inextrincável de universalidade - talvez Borges, ao resgatá-la e recuperá-la em outro contexto tenha conferido a ela tal qualidade - senão por desvelar o problema central que caracteriza a ideia, pregnante em especial no século XX e que no presente se radicaliza, segundo a qual o recrudescimento do rigor cientifico, substanciado na suposta precisão de seus instrumentos e métodos, e numa confiança inabalável nas suas divisões epistemológicas, é o inexorável caminho para o progresso das ciências de qualquer natureza. A necessária aproximação da presente proposta à uma análise da situação atual da ciência se dá devido ao resgate e a aproximação da música com uma "certa" ideia de ciência que não só não é nova, como equivocada. Mais ainda: esta ideia tornou-se a premissa básica da pesquisa e contaminou todas as ciências humanas no século XIX a partir do positivismo científico, se fortaleceu nas artes do século XX e permanece paradigmática na música, malgrado a crise do paradigma científico se arraste desde os postulados de Albert Einstein, colocando em cheque esta ideia de ciência ${ }^{29}$. No caso da música, longe de querer demonizar o pensamento oriundo das diversas emanações de uma lógica da consistência, cuja matriz se verifica nas disposições canônicas formuladas a partir das metafísicas do absoluto no século XIX e no legado idealista pitagórico-platonico verificado no formalismo, vemos que estas premissas -

\footnotetext{
${ }^{29}$ Cf. SOUSA SANTOS, 1988.
} 
que são novas metafísicas, novos discursos totalizantes - se imiscuem na formação das vanguardas artísticas, especialmente as musicais que se fortaleceram nos cursos de Darmstadt, em cujas experiências se baseiam em grande parte o ideário da Neue Musik; e não será difícil, no momento oportuno, demonstrar que a maior parte dos problemas da estética da música do século XX são oriundos da associação da teoria musical e das poéticas musicais a esta ideia do que é a ciência, e mais ainda, da ideia de que a música, em sendo também ciência, deve especificamente ser esta ciência, que desde os anos 60 e 70, no auge mesmo das neo-vanguardas artísticas reconhece a crise de seus paradigmas, e especula sobre quais seriam os novos ${ }^{30}$.

\footnotetext{
${ }^{30}$ O sociólogo português Boaventura de Sousa Santos distingue dois tipos de paradigmas quando traça uma espécie de história social da ciência: de um lado o paradigma dominante, que tem um longo percurso desde os postulados mais antigos ainda no século XVI, passando pelo racionalismo cartesiano e desembocando no positivismo do século XIX, que não só se estabeleceu como se manteve impregnando as ciências sociais e históricas ao longo do século XX. De outro lado, após as novas descobertas da ciência moderna, principalmente após Albert Einstein, surge a inexorável necessidade de novos paradigmas, que, segundo Sousa Santos, só podem ser especulados; este paradigma emergente residiria, segundo o autor, na admissão da impossibilidade da neutralidade científica, no reconhecimento dos limites da matemática e dos antigos modelos empíricos, e na possibilidade de radical interdisciplinaridade com as ciências humanas e filosóficas. A base do paradigma dominante: "A matemática fornece à ciência moderna, não só o instrumento privilegiado de análise, como também a lógica da investigação, como ainda o modelo de representação da própria estrutura da matéria. Para Galileu, o livro da natureza está inscrito em caracteres geométricos e Einstein não pensa de modo diferente.Deste lugar central da matemática na ciência moderna derivam duas conseqüências principais. Em primeiro lugar, conhecer significa quantificar. O rigor científico afere-se pelo rigor das medições. As qualidades intrínsecas do objecto são, por assim dizer, desqualificadas e em seu lugar passam a imperar as quantidades em que eventualmente se podem traduzir. O que não é quantificável é cientificamente irrelevante. Em segundo lugar, o método científico assenta na redução da complexidade. O mundo é complicado e a mente humana não o pode compreender completamente. Conhecer significa dividir e classificar para depois poder determinar relações sistemáticas entre o que se separou (1988, p.4-5).O que se tem, doravante, é a crise desse modelo de ciência: São hoje muitos e fortes os sinais de que o modelo de racionalidade científica que acabo de descrever em alguns dos seus traços principais atravessa uma profunda crise. (...) primeiro, essa crise é não só profunda corno irreversível; segundo, que estamos a viver um período de revolução científica que se iníciou com Einstein e a mecânica quântica e não se sabe ainda quando acabará; terceiro, que os sinais nos permitem tão-só especular acerca do paradigma que emergirá deste período revolucionário mas que, desde já, se pode afirmar com segurança que colapsarão as distinções básicas em que assenta o paradigma dominante (...) (p.8). Assim sendo, a necessidade e emergência de um novo paradigma se coloca na impossibilidade de se manter essa posição "meta" do cientista, bem como na destruição da velha forma de se pensar, que cada vez mais se traveste de novas formas: (...) podemos afirmar hoje que o objeto é a continuação do sujeito por outros meios. Por isso, todo o conhecimento científico é auto-conhecimento. A ciência não descobre, cria, e o ato criativo protagonizado por cada cientista e pela comunidade científica no seu conjunto tem de se conhecer intimamente antes que conheça o que com ele se conhece do real. Os pressupostos metafísicos, os sistemas de crenças, os juízos de valor não estão antes nem depois da explicação científica da natureza e da sociedade. São parte integrante dessa mesma explicação. A ciência moderna não é a única explicação possível da realidade e não há sequer qualquer razão científica para a considerar melhor que as explicações alternativas da metafísica, da astrologia, da religião, da arte ou da poesia" (p. 19).
} 
Em arte, um dos críticos mais ferrenhos - e que lançou um olhar filosófico sobre essa associação entre a absorção dos pressupostos científicos na arte - da imbricação embaraçosa entre arte e ciência no pensamento contemporâneo é o poeta brasileiro Ferreira Gullar. Seja nos seus ensaios estéticos e políticos, seja em entrevistas, Gullar, inicialmente um entusiasta do movimento da poesia concreta no Brasil, passa a reconhecer de modo muito consciente as possibilidades de empobrecimento da arte e do pensamento sobre arte, caudatários dos programas vanguardistas. Aponta a confusão conceitual, que veio a se transformar num problema estético central entre a ideia de experimentalismo e a ideia de vanguarda -"Não é necessário haver movimentos de vanguarda para que os artistas criem obras de alto valor e para que a arte se renove" (GULLAR, 2006, p.11) - assunto ao qual Umberto Eco dará especial atenção em suas coletâneas de ensaios A Definição da Arte (1972) e Sobre os Espelhos (1989).

A discussão de fundo, e as bases conceituais que orientam essa discussão, que culmina nos problemas oriundos da imbricação arte-ciência e nos usos e campos lançados a partir desta mesma imbricação, envolve um conceito fundamental: o conceito de teoria ${ }^{31}$; conceito aberto, que paradoxalmente se transformou no principal avatar na manutenção dos paradigmas dominantes, seja na ciência, seja na invenção de obras de arte - e aqui as vanguardas devem assumir a maior responsabilidade - que buscam o fechamento e o recrudescimento das questões envolvidas.

Esta crise de paradigma não se localizou especificamente nas possibilidades de abordagem das ciências empírico-matemáticas - cuja pregnância na música é forte ainda hoje no campo das teorias analítico-musicais - mas também nas ciências sociais e históricas, devido ao grande número de disposições canônicas transformadas em paradigmas. Essas disposições canônicas, mesmo quando longe do positivismo, são prejudiciais para uma tentativa de reavaliação dos problemas em arte. No caso das abordagens sociológicas, o ícone mais claro se perfaz na influência da sociologia e filosofia da música de Adorno. Se admitirmos uma crise de paradigma na sociologia e filosofia da música, seu sintoma aparece na necessidade urgente de um pensamento pósAdorno nessas áreas, como nos mostram J. Ginzburg (2013) e Tia DeNora (2003).

\footnotetext{
${ }^{31}$ Ferreira Gullar expõe assim a situação limite da imbricação arte-ciência vista no sintoma da relação artista-teórico: "Como a teoria vai tomando lugar da prática, o peso do crítico tende a crescer, na medida mesmo em que o artista se torna teórico e o crítico se torna artista. Teóricos e artistas de uma arte sem obras. A consequiência disso é, a meu juízo, uma crescente confusão no terreno dos conceitos sobre arte" (GULLAR, 2006, p.77).
} 
Boaventura de Sousa Santos demonstra que a crise do paradigma científico - e aqui ele inclui as ciências humanas - é a crise de um pensamento relutante ainda em reconhecer seus limites; reconhecer a necessidade de um novo paradigma, uma vez que não é mais possível relativizar uma situação que há tempos se confere como fato:

\begin{abstract}
O rigor científico, porque fundado no rigor matemático, é um rigor que quantifica e que, ao quantificar, desqualifica, um rigor que, ao objectivar os fenómenos, os objectualiza e os degrada, que, ao caracterizar os fenómenos, os caricaturiza. Finalmente, uma forma de rigor que, ao afirmar a personalidade do cientista, destrói a personalidade da natureza. Nestes termos, o conhecimento ganha em rigor o que perde em riqueza e a retumbância dos êxitos da intervenção tecnológica esconde os limites da nossa compreensão do mundo e reprime a pergunta pelo valor humano do afã científico assim concebido. Esta pergunta está, no entanto, inscrita na própria relação sujeito/objecto que preside à ciência moderna, uma relação que interioriza o sujeito à custa da exteriorização do objecto, tornando-os estanques e incomunicáveis (SOUSA SANTOS, 1988, p.11-12).
\end{abstract}

Hilton Japiassu não hesita mesmo em dizer, sobre essa crise nas ciências humanas, que a estas talvez valha mais a pena que se desembaracem "de seu complexo de inferioridade epistemológica relativamente às ancestrais da natureza" (2012, p.19). Aliás, na contundente introdução de seu A Crise das Ciências Humanas, o autor traça um perfil nada animador da situação das ciências humanas, mostrando como, historicamente, os modelos pregnantes do anseio empirico-matemático puderam legar não só uma crise de humanismo nas humanidades como a desconfiança quanto às possibilidades de uma ciência humana de fato.

Não é difícil associar as questões que viemos apresentando até aqui quanto à dificuldade de delineamento epistemológico para novas possibilidades do pensar estético, quando vemos que isso é parte de uma crise maior, que, a partir do advento do estruturalismo, pôde inclusive se opor "às tentativas de se privilegiar o homem e sua consciência" (JAPIASSU, 2012, p.17) exercendo uma enorme influência mesmo nos estudos históricos.

Como pretendo demonstrar mais tarde, os efeitos deste descarte do homem realizado pelas ciências tem uma correspondência imediata nas artes com a perda do "mundo" nas obras. A vontade de aniquilação que se observou a partir das vanguardas artísticas, especialmente a partir da segunda metade do século XX, é sintomática desta negação do homem, sobre o homem inscrito sob o signo do nada; e esse afastamento da ciência de qualquer ponto de apoio no elemento humano foi um dos pilares resultantes de uma premissa iluminista que "por uma questão de principio ético", imaginou que 
deveria ser imposto "a toda forma de conhecimento o modelo das ciências fisicosmatemáticas e seus métodos de abordar a realidade imaginando uma perfectibilidade que só "poderia ser garantida pelo progresso ilimitado do conhecimento cientifico e das tecnicas" (ibidem, p.16).

Confluente com a linha que adotamos para pensarmos criticamente a situação do pensamento sobre música está o modo como a pregnância de uma ideia de ciência onde as questões parece que estão "decalcadas para sempre na grande demarcação separando irremediavelmente a racionalidade cientifica de todas as demais formas de saber: míticas, ideológicas, literárias, e filosóficas"(ibidem, p.19); a partir daqueles residuais de uma noção sincrônica, teleológica, que imagina que o progresso da ciência existe e só pode ocorrer com o enrijecimento do rigor matemático, temos um paralelo nas abordagens musicais onde a ciência da música só poderia se dar na justificativa de sua consistência,

como se as ciências humanas devessem se abster definitivamente de relacionar-se com o político e o moral, adotar de vez a ideologia cientificista da neutralidade axiológica e libertar-se para sempre do fantasma de poder decidir, em matéria de organização da sociedade, sobre o justo e o desejável para o homem, devendo contentar-se em elaborar discursos justificadores e racionalizadores da ordem social (JAPIASSU, 2012, p.19).

De fato, a tentativa de conferir ao homem o estatuto de coisa, trouxe grande parte dos efeitos deletérios aderentes no compartimento epistemológico das ciências. A emergência de se repensar novas formas de a ciência pensar o homem, encontra paralelo na urgência de um pensamento que possa repensar aquela que talvez seja a mais humana das produções humanas: justamente a arte.

É essa emergência, que apontei na introdução geral deste estudo, que tem sido posta em questão por inúmeros pensadores, que vêem a hiperespecialização do conhecimento como o maior dos problemas para que possa ser recolocado o homem no centro da abordagem. Para Edgar Morin,

O conhecimento especializado é em si mesmo uma forma particular de abstração. A especialização abs-trata, ou seja, o ato de extrair um objeto de um campo determinado rejeita as ligações e intercomunicações desse objeto com seu meio, insere-o em um setor conceitual abstrato, que é o da disciplina compartimentada, cujas fronteiras rompem arbitrariamente a sistemicidade (a relação de uma parte com o todo) e a multidimensionalidade dos fenômenos. Ela conduz à abstração matemática que produz uma cisão de si mesmo com o concreto, de um 
lado privilegiando tudo que é calculável e formalizavel, de outro, ignorando o contexto necessário à inteligibilidade de seus objetos (MORIN, 2011, p.48).

A crítica de Morin ainda inclui o isolamento da filosofia - aquele isolamento que faz dela um lugar com pouco oxigênio para que o homem social possa respirar - como parte deste problema onde "a possibilidade de pensar e o direito ao pensamento são recusados pelo próprio principio de organização disciplinar dos conhecimentos científicos e pelo fechamento da filosofia em si mesma" (ibidem, p.52) e onde são tomados os problemas como "interdependentes no tempo e no espaço, enquanto as pesquisas disciplinares isolam os problemas uns dos outros" (p.51).

Se pensarmos ainda com Paul Feyerabend, outro crítico mordaz do paradigma dominante, o tempo atual urge por algo ainda mais radical do que um realinhamento e uma flexibilização epistemológica. Feyerabend, em suas principais obras - Contra o Método (1977) e Adeus a Razão (1991) - põe em cheque o conceito de racionalidade aplicado às ciências, demonstrando como as noções de razão e objetividade que ainda as regem, e de forma cada vez mais severa, serviram e servem às formas de autoritarismo e preconceito com outros modos de pensamento. Assim sendo, sua proposta se concentra na ideia de pluralismo e aceitação de diferentes métodos. Segundo este autor faz-se necessário até mesmo o que ele chama uma "anarquia epistemológica"; esta seria menos hipócrita, uma vez que mesmo nas ciências duras as ideologias dominantes promovem uma verdadeira segregação de campos, no intuito - cuja ética duvidosa é frequentemente ofuscada pela noção de progresso - de garantir sua manutenção ideológica, cuja lógica é a reserva de mercado. $\mathrm{O}$ anarquismo epistemológico seria mais realista e menos demagogo, e é, ao contrário de uma ciência governada por normas fixas, a condição necessária para o desenvolvimento. Feyerabend não se furta a apontar as estratégias realizadas - que são violentas - para garantir os postulados científicos de determinada corrente, demonstrando que mesmo em tempos remotos, a publicidade e a propaganda ajudaram a garantir certa ideia do que a ciência deveria ser.

As noções que ele lança, são aplicáveis à uma crítica à história que obviamente se pode estender à uma crítica dos campos construídos em torno de uma "certa" ideia de $\operatorname{arte}^{32}$, que se tornou hegemônica, e após o advento das vanguardas e neo-vanguardas do século XX, se aliaram a uma determinada noção de arte como ciência. No sentido

\footnotetext{
${ }^{32}$ Veremos, em momento posterior, como isso de dá na música. Procurarei lançar mão de um estudo sobre o modo como se estabeleceram as bases para a hegemonia da vanguarda musical do século XX.
} 
apresentado pelo autor, a concepção racionalista ocidental de mundo estabeleceu que toda forma de conhecimento é uniforme e sujeita à leis universais. Feyerabend aponta que o racionalismo ocidental determinou que uns detêm o conhecimento "verdadeiro", inacessível a outros.

Neste sentido, a mera opinião de filósofos e cientistas ao longo da história, ao mesmo tempo que construiu muitas formas de conhecimento, destruiu, através de estratégias de dominação, muitas outras. Assim sendo, o anarquismo epistemológico rejeita a forma hegemônica da teoria sobre o conhecimento, uma vez que o conhecimento surge primeiro que a teoria. Em música, é possível ver como isso é evidente.

\footnotetext{
Mesmo as teorias mais abstratas, apesar de não históricas em intenção $e$ formulação são históricas no uso: a ciência e os seus antecessores filosóficos fazem parte de tradições históricas especiais, não são entidades que transcendem toda a história (FEYERABEND, 1991, p,146).
}

Se a radicalidade do pensamento de Feyerabend pode ser desconcertante, e neste caso estamos apenas colocando este pensamento como alternativa, não encerrando uma posição com ele - o que seria um paradoxo, pois uma das hipóteses aqui lançadas aventam a contradição por trás de posições radicais - por outro lado sua reflexão nos mostra que em plena era dos discursos fragmentários, da necessidade de um pensamento que, em qualquer área deve ser tomado com o devido cuidado contextual - o sociólogo Stuart Hall ${ }^{33}$ fornece importantes indícios da necessidade de abordagem cada vez mais plurais - o que se vê é o aprofundamento de um paradigma científico que não mais se corresponde à esse Zeitgeist, justamente por estar, pelo menos desde os postulados mais remotos da mecânica quântica, em crise. De certa forma, pode-se dizer que a insistência do modelo positivista, tornado epigonal, se mantém vivo e até dominante nos discursos científicos, o que demonstra que, na verdade, a modernidade ainda é uma narrativa inacabada, cuja essência, ao que parece, reside no aprofundamento de paradoxos.

\footnotetext{
${ }^{33}$ Hall transporta o conceito de cultura como um determinado estado de coisas para repensá-la enquanto factualmente ocorrente num determinado local, num determinado tempo, através da noção da linguagem, de forma relacional. As coisas não têm significado, apenas é dada a elas uma construção da linguagem onde os significados são atribuídos e dinamicamente modificados pela ação material do homem (cf. HALL, 2013).
} 


\subsection{Sobre os limites e vícios da ciência: a possibilidade de cientifização da estética}

Poderemos quiçá encontrar outras possibilidades de pensar a próprio âmago da ciência de forma a nos distanciarmos das totalizadoras pretensões do positivismo. Se como vimos Stephen Hawkins proclama, sem rodeios, a morte da filosofia, é menos porque se acredita de fato na morte da filosofia enquanto pensamento que busca fundamentos e verdades do que a intenção de imposição do postulado da ciência como a única possibilidade na busca por respostas legítimas para todas as principais questões nos diversos e vastos campos do conhecimento ${ }^{34}$.

Mas o que se entende por ciência está sempre e por excelência ligado aos modelos empírico-matemáticos, que, tomados em sua eminência objetiva, descarta outros modelos de pensamento, mais especulativos. Em se considerando a premissa dialética objetividade-subjetividade (tomada pela ciência e dissolvida pela hermenêutica ontológica), Morin aponta ainda que "a subjetividade não é inimiga do exame objetivo das realidades. É necessário ser um sujeito/ator crítico" (MORIN, 2011, p.142). E, sobre os modelos objetivo-matemáticos, como afirma Sousa Santos, por serem matemáticos, tampouco são mais verdadeiros. Paul Feyerabend aponta ainda que o problema dessa crença epistemológica pode estar enraizado em um outro, metodológico:

[...] a ideia de a ciência se sobrepor a todas as outras formas de vida provém
da área da metodologia: a unidade fictícia "ciência" que deve excluir tudo o
mais, pura e simplesmente não existe. Os cientistas recolheram ideias dos
mais diversos campos, com suas opiniões a colidirem muitas vezes com o
senso comum e as doutrinas estabelecidas, e sempre adaptaram os seus
procedimentos à tarefa em mãos. Não existe um 'método cientifico', mas uma
grande dose de oportunismo; tudo serve - quer dizer, tudo o que é susceptível
de fazer progredir o conhecimento na perspectiva de um investigador privado
ou de uma tradição de investigação (FEYERABEND, 1991, p.49).

Na verdade a colocação de Hawking deixa entrever dois problemas conceituais. Eles são exatamente os dois equívocos aos quais queremos nos referir: 1) Mesmo

\footnotetext{
${ }^{34}$ É interessante notar que quase todos os livros sobre história da ciência - notadamente os de Hawking traçam um perfil sincrônico da evolução do saber cientifico, localizando sua origem nas concepções cosmológicas e filosóficas dos gregos até seu ponto culminante na utilização da alta tecnologia nas verificações do mundo quântico, demonstrando que estamos em uma época em que as respostas não poderiam mais se dar no campo da filosofia, somente no campo dos modelos experimentais e dos modelos matemáticos. Sem dúvida as constatações que buscam este viés não poderiam ser mais sintomáticas da desenfreada busca por se comprovar a morte do homem (Foucault) na mecanização do humano. Assim, "pela primeira vez na tradição dos gregos, eles se desviam do cosmo, do destino do homem no mundo, dos paradoxos do real" (MORIN, 2011, p.52).
} 
carregada de matemática, toda teoria científica parte de especulações, e neste sentido, ela é de eminência filosófica. Ou seja, a filosofia não só não morreu como é condicional pensar através de seus métodos neste tipo específico de ciência. Ou seja, Hawking e outros cientistas atuais divulgadores de ciência fazem filosofia menos porque enquanto cientistas tenham usurpado a tocha do conhecimento do que pelo caráter especulativo de suas teorias, que, embora apoiados por modelos matemáticos, ainda possuem pressupostos especulativos. Na verdade, trata-se mais de filosofia do que ciência ${ }^{35}$. 2) Os números e as supostas provas empíricas estão carregadas de algumas incertezas. Ou seja, se de fato temos mais certeza matemática de algo, por esse algo ser comprovado empiricamente, isso não garante uma posição supostamente meta da ciência com relação às coisas.

Como consequência, temos que, se nas ciências, especialmente as duras, o risco de um pensamento confiante no próprio progresso e nas metodologias instrumentalizadas a partir de critérios ad hoc ainda podem valer a pena, devido principalmente a possibilidade de mensurabilidade de muitos de seus pressupostos e, malgrado a conveniente apropriação ideológica que hipostasía os critérios que definem aquilo que é ou não cientifico, tais vícios, quando são transpostos para todas as esferas do pensamento, acarretam a provável transformação de qualquer abordagem estética em mera tautologia, com o risco de que todo o objeto, especialmente o artístico, possa jazer em ruínas habitadas por corvos, como no antigo conto de Miranda exposto no início deste capítulo ${ }^{36}$.

Umberto Eco, ao examinar o que chama de uma certa tendência em cientificizar a filosofia da arte, não hesita em lançar um estudo de caso que, segundo suas próprias palavras, "só não é risível porque representa uma tendência estética importante"; no caso examinado, Eco se detém na proposta de uma estética científica de Léon Bopp (cf. ECO, 1972), que busca uma análise pretensamente precisa e descritiva, ao modo científico. O levantamento e o modo como Eco seriamente lida com o exame dos pressupostos apresentados pelo autor não escondem a inconsistência filosófica que

\footnotetext{
${ }^{35}$ Heidegger demonstra a insustentabilidade da ciência enquanto detentora da verdade e argumenta que a ciência que caminha no sentido da desocultação transforma-se em filosofia. "Sempre que, e na medida em que, uma ciência ultrapassa o correto em direção a uma verdade, a saber, um desvelamento (Enthüllung) essencial do ente como tal, ela é filosofia" (HEIDEGGER, 2005 [1935], p.50).

${ }^{36}$ Edgar Morin: Há uma urgente necessidade "de um pensamento que reconheça sua imperfeição e negocie com a incerteza, sobretudo na ação, porque não existe ação senão no incerto" (2011, p.60).
} 
aparece como efeito colateral da busca pela consistência científica dentro de uma abordagem estética.

No entanto, o efeito final que se tem a partir da abordagem de Bopp é um excelente demonstrativo do quão absurdo pode redundar as tentativas de mensurabilidade objetiva de elementos ligados à invenção artística. E, antes que entremos no aprofundamento de certas questões levantadas até aqui, é preciso dizer que mais natural e salutar seria se as ciências adotassem o discurso aberto da estética, a fantasia do pensamento que pode ser legado pelas artes. Neste sentido, novamente, o artista tem muito a oferecer ao filósofo e ao cientista: "Em nossas sociedades, somente os poetas, os artistas e os inventores - como seres desviantes - são capazes de ser criativos e de gerar qualquer coisa" (MORIN, 2011, p.45).

Neste ponto da reflexão, é necessário que se exponha de forma um pouco mais sistemática as questões que envolvem as possibilidades de abordagem da música, no intuito de quiçá clarificar confusões conceituais entre os campos, que malgrado toda a tentativa moderna de epistemologização, terminaram por embaçar-se. Como o já esboçado nestas reflexões, não se pode confundir a necessidade iminente de uma interdisiplinaridade - a mais efetiva possível - com uma confusão conceitual entre os campos de atuação do pensamento e da pesquisa sobre arte e música.

A interdisicplinaridade é a conditio sine qua non da sobrevivência da filosofia da música, e se a estética é a filosofia inteira, e não apenas parte da filosofia, porque não nos arriscarmos na hipótese de que à filosofia o status de autônoma já não lhe cai bem? É preciso que ela se imiscua nas demais ciências, não para se perder nelas; antes, mantendo a sua natureza mesma de filosofia, colher os dados para sua deflexão. Uma deflexão que a leve a caminhos paralelos com a ciência, desde que essa assuma as suas limitações:

$\mathrm{Na}$ ciência moderna o conhecimento avança pela especialização. O conhecimento é tanto mais rigoroso quanto mais restrito é o objecto sobre que incide. Nisso reside, aliás, o que hoje se reconhece ser o dilema básico da ciência moderna: o seu rigor aumenta na proporção directa da arbitrariedade com que espartilha o real. Sendo um conhecimento disciplinar, tende a ser um conhecimento disciplinado, isto é, segrega uma organização do saber orientada para policiar as fronteiras entre as disciplinas e reprimir os que as quiserem transpor. É hoje reconhecido que a excessiva parcelização e disciplinarização do saber científico faz do cientista um ignorante 
especializado e que isso acarreta efeitos negativos (SOUSA SANTOS, 1986, p.17).

Umas vez reconhecidos os efeitos deletérios de uma excessiva distinção de campos epistemológicos, bem como a necessidade de uma filosofia consistente com a pluralidade de papéis em jogo nos diversos campos, elegi 3 temas mais gerais sobre a música onde uma hermenêutica se faz necessária. Estes 3 temas se consubstanciam em uma só grande área: a teoria musical; e duas formas de abordagem: a científica e a filosófica, das quais, como exercício (metalinguístico) examinaremos com o pensamento próprio da filosofia. Para tanto, buscaremos elementos da história da música e da ciência que possam elucidar determinados pontos. Doravante, devido ao caráter distintivo - no que diz respeito aos conceitos filosóficos - tanto da teoria estética de Luigi Pareyson, quanto da sua filosofia geral, me apropriarei novamente delas para melhor tentar esclarecer e especular sobre os problemas que circundam estes temas.

\subsection{Problemas conceituais na abordagem teórico-musical: a escolha pela estética.}

As questões que envolvem os problemas em teoria musical, não fogem - como todos os problemas que de fato valem a pena serem analisados - da necessidade de um debate sobre os conceitos que os circundam. Em primeiro lugar porque os conceitos frequentemente se cristalizam em vícios de linguagem e pensamento; em segundo porque o próprio aparato simbólico do conceito se encontra num combate entre o historicamente determinado versus o conceito re-significado. O filósofo italiano Luigi Pareyson foi um dos que se preocuparam com a possibilidade de distinções conceituais que superassem aqueles dados tomados como verdades apriorísticas, baseados numa mecânica de difícil superação. Pareyson lança um pensamento que busca uma distinção conceitual no seio da própria filosofia, quando propõe a possibilidade de a pensarmos dentro de uma relação entre sua possibilidade revelativa e sua possibilidade expressiva, a qual podemos colocar no âmbito uma outra distinção, justamente aquela entre poética e estética, que diz respeito às possibilidades de sua abordagem filosófica da arte. Um exame mais detalhado destas questões será proposto mais adiante, quando buscarei lançar uma definição de arte que inclui essas distinções de Pareyson que venho apresentando. No entanto, para uma visão necessária para este ponto do estudo, é necessário que se adiantem já alguns elementos. Segundo Pareyson, uma abordagem 
filosófica revelativa deve levar em conta a possibilidade de um desvelar multíplice e plural dos aspectos que se queiram elucidar através do pensamento filosófico; as filosofias revelativas, segundo o autor, são justamente aquelas que devem ser avaliadas segundo uma perspectiva também revelativa ou especulativa, pois,

(...) ascendem ao nível de suscitar uma discussão especulativa, mesmo possuindo um lado expressivo que inevitavelmente acompanha a sua dimensão revelativa. Este pensamento manifesta a verdade. O ser faz-se perspectiva viva sobre a verdade. Revelação pessoal do verdadeiro (PAREYSON, 2005, p.7).

A dimensão expressiva ou historicista serviria mais àqueles pensamentos filosóficos de cunho especificamente historicista, uma vez que "(...) nega à filosofia aquele valor de verdade ao qual ela parece ambicionar pela própria natureza de seu pensamento, e não lhe reconhece outro valor do que ser expressão do próprio tempo (ibidem)". Esta distinção que o autor faz deve ser lida com cuidado. A verdade a que ele se refere, não remete a necessidade de um pensamento ideal, ou idealizado da verdade.

Antes, deve ser interpretado como uma busca por parâmetros mais gerais e aplicáveis de forma mais aberta, onde a pregnância histórica e ideológica imanente não determinam um significado encapsulado em sua expressão cultural-social-temporal. Na realidade, Pareyson, como o já dito em momento anterior, se apresenta sempre como uma boa alternativa para o pensamento sobre arte, especialmente por jamais desprezar o cunho social imanente à qualquer abordagem. E principalmente por rejeitar deliberadamente um postura metafísica da $\operatorname{arte}^{37}$.

Se na filosofia de Pareyson se busca distinguir duas possibilidades de se pensar a própria filosofia, em sua teoria estética ele busca diferenciar o caráter operativo e programático da poética (ofício do artista) do caráter especulativo e não normativo da

\footnotetext{
${ }^{37}$ Umberto Eco, procurando examinar o contexto em que surge a estética pareysoniana diz: "no panorama desta concepção estética ampla e desprovincianizada surge a teoria da formatividade de Pareyson que, à concepção idealista da arte como visão, opõe um conceito de arte como forma (...)" (ECO, 1972, p.14). Esse conceito de arte como forma, em Pareyson, claro deve ficar, não atina diretamente a todo ideário do formalismo tal como o demonstramos anteriormente. Enquanto o formalismo, mais especificamente dentro de sua acepção tomada no âmbito do universo musical, levou à uma idealização arte-pela-arte, legou uma antiga pregnância pitagorico-platonica, tendo em parte contribuído para a adesão desta certa ideia de ciência que estou a examinar aqui. A formatividade de Pareyson lança uma definição de arte como uma fazer. Posteriormente investigaremos com mais detalhes de que forma isso se apresenta. Por hora basta apontar que Pareyson deixa entrever que, malgrado a abordagem específica que a arte requer, a formatividade está presente em "toda operosidade humana". Assim sendo, apesar de assumir o caráter eminente do desvelar resgatado por Heidegger, Pareyson visa manter a obra com um dos pés no do fazer do mundo material.
} 
estética (ofício do filósofo), como apresentei anteriormente. Pareyson chama a atenção para a confusão que se faz frequentemente entre "estética e poética: a distinção entre estética e poética é particularmente importante e representa, entre outras coisas, uma preocupação metodológica cuja negligência conduz a resultados lamentáveis" (2001 [1966], p.4). Se nos lembrarmos que a estética tem um caráter filosófico e especulativo enquanto que a poética, pelo contrário, tem um caráter programático e operativo, não deveremos tomar como estética uma doutrina que é, essencialmente, uma poética. "Isto é, tomar como conceito de arte aquilo que não quer ou não pode ser senão um determinado programa de arte" (ibidem, p.15).

Este modo de pensar pode nos fornecer uma lente através da qual podemos olhar os vários problemas conceituais que circundam as possibilidades de várias naturezas de abordagem teórica.

Também justifica a nossa escolha por um destes modelos de abordagem, justamente uma abordagem especulativa, estética. Segundo Ivo Supičić, pode-se distinguir as abordagens estéticas/filosóficas das históricas/sociológicas (que no caso pareysoniano se consubstanciam em proximidade com as filosofias expressivas essencialmente pela metodologia, pois enquanto a estética musical pressupõe uma análise filosófica especulativa e dedutiva,

(...) a sociologia da música e a história social da música, permanecendo exclusivamente ciências, devem proceder apenas por uma abordagem estritamente científica, não filosófica, de fatos. No entanto, a sociologia da música e a história social da música não são ciência no sentido positivista da palavra: eles mantêm estreitas relações com a filosofia implícita ou explícita do cientista (SUPIČIĆ, 1986, p. 223).

Podemos tomar os dizeres de Supičić, no sentido de que se possa refletir sobre música levando em conta as naturezas distintivas dos campos, sem que se deixe, no entanto, de promover, a partir do arcabouço da filosofia, a imbricação entre eles.

Partindo deste princípio, podemos pensar em pelo menos 3 naturezas para abordagem em música: a) uma especulativa e não normativa, realizada enquanto estética ou filosofia da música; b) histórica ou sociológica, cuja filosofia implícita pode ser deduzida de dados tomados de um arcabouço empírico, portanto científico, sem que se culmine numa abordagem positivista; c) analítica, que em música, é o que mais se aproxima dos modelos teóricos de descrição das ciências. Aqui, partimos da primeira para abordar as demais, principalmente a terceira. 
O problema colocado por Luigi Pareyson quanto à possibilidade de uma filosofia que possa ser mensurada pela sua pregnância ou autonomia histórico-ideológica, deve , de fato, aproximar a filosofia da obra de arte. Estes problemas também foram nodais na abordagem de Heidegger, que aprofundou sua filosofia da origem da obra numa tentativa de superar este "pensamento que há muito se tornou corrente", postulando uma abordagem em que a arte se dá na singularidade e autonomia da obra, alcançada por uma filosofia que busca a essência das obras (e das coisas) e se realiza ao tentar compreendê-la no repouso de "seu-puro-estar-em-si-mesma"; enfim, na reflexão sobre o mundo aberto pela própria obra (cf. HEIDEGGER, 2005) ${ }^{38}$, conotando um arcabouço não normativo para o pensamento sobre arte. Assim sendo, este modo de pensar uma forma de abordagem que considere a imbricação entre as obras ou movimentos artísticos, suas recepções - sempre recortes ideológicos - de onde nascem suas teorias, e como as teorias que dão origem às obras podem ser pensadas a partir de suas recepções, pode ser tomado pela análise estética.

No entanto, a radicalização de uma análise que tome exclusivamente a obra em sua suposta autonomia, frequentemente gera problemas, como procurei já clarificar no início. Eis então, um dos problemas para um delineamento epistemológico eficaz para uma proposta atualizada da disciplina estética: em se tomando esse campo em específico, como respeitar sua natureza e ao mesmo tempo fugir de um ideário metafísico da arte? Conforme vamos avançando, uma coisa é notável: uma abordagem estética vai, pela sua própria vocação, tender ao mundo da obra. Mas como evitar sua desconexão com o mundo do homem, mantendo as suas próprias características de pensamento revelativo de um campo específico?

Em se mantendo pregnante as formas históricas de um idealismo legitimador, não se poderia negar àquela acusação de Bourdieu certa verdade. Neste caso, de fato, o idealismo estético autonomista, principalmente na manutenção da hegemonia croceana, seria o local da negação "do social". No entanto, é um erro um tanto óbvio o julgamento de toda a disciplina baseado nos vícios de alguns de seus tipos de abordagem ${ }^{39}$, mesmo

\footnotetext{
38 Obviamente não devemos cair no ingênuo equívoco de que Heidegger tem a utópica pretensão de "isolar" a obra de seu contexto histórico; a profundidade de sua abordagem, como procurarei demonstrar mais tarde, busca definir as condições de essência e fundamento da arte em sua emanação nas obras.

39 Em suas obras de cunho teórico-filosófico, o poeta Ferreira Gullar expõe um pensamento fenomenológico, em grande parte influenciado por Merleau-Ponty, onde critica esta "(...) necessidade de abranger aspectos novos do real como também de uma tentativa de "fundar o ser", segundo a visão heideggeriana, o que significa assumir uma posição idealista em face do mundo." Essa posição é colocada, mantendo a terminologia da qual estamos fazendo uso, numa relação com as poéticas de
} 
que estes tenham embasado, no caso da estética musical, diversas tendências hegemônicas, o que, como vimos, é parte do problema epistemológico que compreendia uma disciplina filosófica enquanto pensamento prescritivo.

Posso me arriscar na afirmação - com base ainda em Pareyson - de que, se é prescritivo, não é filosofia. Ou é apenas o lado expressivo de determinada filosofia.

Todo este pensamento que busca uma explicação ontológica, uma hermenêutica mais geral dos problemas da arte e sua origem, são também modelos de descrição da realidade, e como bem chamou Pareyson a sua estética da formatividade, "teoria". Neste ponto, se faz necessário lembrar que se pode distinguir duas conotações que usarei aqui para teoria. Se minha escolha para a abordagem do objeto - a disciplina estética - é a própria estética, devo prosseguir demonstrando que ele é eficaz enquanto modo de investigação. A prática sendo construída já na busca de comprovar a teoria. E dentro de qual conceituação podemos pensar 'teoria'?

\subsection{A natureza da estética; as múltiplas conotações de teoria; o vínculo da vanguarda com o paradigma dominante; por uma paradigma emergente para a música}

Teoria pode ser tudo aquilo que atina diretamente à uma determinada prática, sendo teoria todo pensamento que visa qualquer "pensar" sobre as coisas, um pensar analógico ao arcabouço de um praxis determinada. Neste sentido, todo o pensamento estético é "teórico". No entanto, podemos pensar mais sistematicamente, sendo teoria somente a proposição de um modelo de pensamento cuja pretensão é servir como um postulado mais geral, ou como se diz na ciência, universal; um modelo que serve como uma descrição da realidade, aplicável aos muitos contextos possíveis.

Neste caso, nem todo pensamento estético se concretiza enquanto uma teoria, e toda teoria deve necessariamente criar um painel modelar que dê conta de uma realidade muito ampla.

Minha opção por uma abordagem estética leva em conta a possibilidade de se distinguir as diversas naturezas das teorias musicais a partir de uma multifária imbricação de disciplinas, bem como entre as teorias e as obras. Assim sendo, é

vanguarda; o paradoxo gerado nesta associação entre o "dogma" da música como linguagem e uma visão idealista que se vincularia aos pressupostos heideggerianos, será tema de exames subsequentes neste trabalho. 
impossível ignorar, dentro do modelo de pensamento que pretendo, que há uma multíplice possibilidade de concebermos um pensamento sobre o conceito de teoria: em sua dimensão histórica, numa abordagem filosófica deduzida de um arcabouço mais materialista (contexto de produção e estudo das recepções), filosófica, dentro das emanações idealistas (a obra e o mundo aberto por ela mesma, sua singularidade e solidão com relação as "meras" coisas - sua relação com as teorias na produção de significados), e científica (qual é a relação limite em que uma teoria deve ser considerada "científica").

Se podemos pensar as possibilidades teóricas tendo como discussão de fundo a distinção que faz Supičić entre uma abordagem estética/filosófica e histórica/sociológica - que se revela sobretudo metodológica - podemos ainda examinar os problemas mais complexos que envolvem as possibilidades de uma pensamento teórico-científico em música, bem como as dificuldades inerentes à aplicação de pressupostos ditos científicos como metodologia da estética.

Para tanto, podemos inicialmente pensar filosoficamente teoria em suas acepções de origem. No caso que colocamos em questão, o conceito de teoria, usado mormente de modo vazio e mecânico, muitas vezes é vitima de uma acepção semântica que passa a conotar certos usos do senso comum, mesmo quando se trata de um senso comum douto.

Em música, um amplo aparato de significados é usado para designar teoria, muitas vezes conduzindo a uma compreensão que a considera como algo apartado da realidade sonora, da realidade da invenção musical, da aisthesis; assim dissociada da práxis, a teoria em música é tomada por um arcabouço de disciplinas áridas, quando não como meras abstrações, quando na realidade, essa visão tende a desprezar que teoria e análise são, por excelência, o elo que re-conecta a multiplicidade da música - através das obras - à sua condição material, numa rede sistêmica que deveria levar em conta inclusive a sua própria manutenção histórica e sua validade social, sempre definidas enquanto estratégias mesmas de manutenção; e não somente à sua condição de ciência. Ademais, a tendência atual de se imbricar teoria e ciência no bojo dos estudos sobre arte na academia, embora faça parte de diversas estratégias iniciadas pelas vanguardas artísticas do século XX, é apenas uma falsa novidade. Se de fato a ciência se manteve a partir do século XX como a autoproclamada única via de explicação do mundo, e essa ideia passou a impregnar o meio musical acadêmico num sentido de resgatar a cientificidade da abordagem musical, numa estratégia mesma de justificar a manutenção 
da música na sua relevância acadêmica, é certo também que o conceito de teoria parece necessariamente querer conotar que estamos no campo, especialmente em música, da ciência vulgarmente compreendida. E aqui é bom que se possa manter como plano de fundo as questões sobre paradigma nas ciências colocadas problematicamente por Boaventura de Sousa Santos e Paul Feyerabend. Sobre a questão da "música-ciência", ou da "arte-ciência", tornadas paradigmáticas a partir do pensamento de vanguarda, não é preciso voltar tanto no tempo, para vermos que isso se dá apenas como um postulado delineador de um campo específico na academia, que busca numa determinada "ideia de ciência" a legitimação de seus postulados.

Não é necessário uma teoria com a pecha da objetividade científica - o que hoje é o equivalente a dizer que estas devem ser baseadas em modelos matemáticos - para que se trabalhe como a "ciência da música"; na realidade, a essência poliédrica da música sempre pressupôs esse seu lado abordável segundo modelos matemáticos. Reiterando, isso não é uma novidade. Como o antes apresentado, já nos tempos do compositor e teórico Rameau (séc. XVIII), a teoria já era designada como ciência da arte (GROUT, D. J \& PALISCA, 2001, p. 434). Mas, mais interessante, seria resgatar o conceito mais originário, para que possamos discuti-lo em seus usos atuais, principalmente em suas delineações ideológicas que determinam campos legitimadores.

\subsubsection{Theoria $(\Theta \varepsilon \omega \rho i \alpha)^{40}$}

Theoria é em sua origem um neologismo. Embora seja difícil precisar qual autor o utilizou primeiro, a data de aparecimento deste conceito coincide com o surgimento das primeiras formulações da filosofia grega nos séculos VII e VI a.C. Os dois verbos relativos à visão, olhar e ver (ó $\dot{\alpha} \omega$ e $\beta \lambda \dot{\varepsilon} \pi \omega$ ) indicando o fenômeno do olhar imediato, foram usados até então. Contudo, com o aparecimento de teoria (na forma de $\theta \varepsilon \omega \rho \varepsilon \dot{\varepsilon} \omega$ ) temos como pressuposto uma forma de visão que, ainda que dependa da visão sensível, atravessa essa sensibilidade no intuito de penetrar agudamente no que seria a natureza ( $\varphi \dot{v} \sigma 1$ ) dos fenômenos. Assim sendo, originalmente a palavra teoria conota uma práxis

\footnotetext{
${ }^{40}$ Toda esta abordagem da origem do conceito de theoria é resgatado de minha dissertação de mestrado (GALON, 2011), quando foi desenvolvida após a parceria entre os professores Rubens Russomanno Ricciardi e Alexandre da Silva Costa, do mesmo grupo de pesquisa Poíesis, Práxis e Theoria em Música pelo CNPq, ao qual pertenço.
} 
da visão, um olhar analítico sobre o concreto, a visão que penetra a fundo as coisas ao redor, um modo distinto do olhar. Neste caso, se a tomarmos sob um ponto de vista tanto histórico quanto filosófico, qualquer suposição hoje de uma teoria apartada do mundo real se torna problemática, não faria sentido enquanto teoria. Neste sentido também, a teoria não é oposta à prática. Assim sendo, qualquer das formas de teoria que aventamos até aqui garantiria sua validade. No entanto, no que diz respeito às possibilidades de teorias científicas em música, no sentido moderno forte, parece-me que deva ser levado em consideração necessariamente a possibilidade da proposição de modelos de compreensão dos aspectos formativos de uma obra musical, suas leis internas, sua poética, deduzidos a partir deste olhar agudo, analítico, sobre a realidade da obra. Neste sentido, as análises musicais abstratas, realizadas no intuito de serem descrições da realidade de uma dada obra musical, bem como de possibilitarem a dedução de modelos de compreensão universais para a análise de obras de mesma poética, não se aproximariam ainda mais do modus operandi das ciências? Em se tratando de teoria musical, vemos que a partir do século $\mathrm{XX}$, com as áreas da teoria se tornando independentes, são justamente as análises musicais - compreendidas enquanto disciplinas autônomas - que se consubstanciam mais especificamente como teorias científicas: mesmo um determinado conjunto de análises de uma dada referência - a musica atonal, por exemplo - pode inspirar todo um sistema teórico que visa se substanciar como uma ferramenta útil para o exame daquela determinada referência musical. Assim sendo, podemos dizer que se as teorias analíticas que buscam modelos descritivos nas poéticas musicais são resultado da observação do comportamento do objeto poético (na realidade da própria formatividade na poiésis) de uma obra ou de um movimento artístico consolidado, podemos qualificá-las então segundo a ideia de um realismo dependente do modelo. A formatividade da obra - sua legalidade interna, seu conjunto de leis próprias que indicam um dado comportamento do material musical - é objeto de uma observação analítica que gera um modelo que a explica, e que indica constantes baseadas na sua coerência, com a finalidade última de se tornar um sistema válido universalmente. Podemos aproximar este aspecto ao modo como a ciência moderna visualiza a problemática em torno dos problemas teóricos, embora sempre por um viés de imanência positivista. Em um de seus últimos trabalhos para o grande público, o físico Stephen Hawking, já apresentado aqui como paladino de um espírito neo-positivista traz as seguintes observações, que podem explicar as pretensões explícitas no moderno conceito de teoria: 
Não há conceito da realidade independente de um quadro ou de uma teoria. Em vez disso, (...) a ideia de que uma teoria física ou uma imagem de mundo é um modelo (geralmente de natureza matemática) e um conjunto de regras conectam elementos do modelo às observações. Isso fornece um quadro com o qual interpretar a ciência moderna (HAWKING, 2010, p. 32).

Hawking ainda segue demonstrando que "diferentes teorias podem descrever com sucesso os mesmos fenômenos, embora dentro de quadros conceituais díspares" (ibidem, p. 33). Em teoria musical, observamos esta dinâmica principalmente no século XX, onde a invasão dos modelos científicos tem buscado colocar a música em pé de igualdade com as outras ciências. A abundância destes modelos, oriundos daquela tentativa de reprodução do pensamento musical nos moldes empírico-matemáticos que muito devem às neo-vanguardas - gera a existência de mais de um modelo teóricoanalítico para o mesmo fenômeno musical, e nenhum pode ser considerado mais verdadeiro do que o outro, muito embora alguns sejam mais elegantes e adequados para observação do objeto. Se de fato as teorias científicas apresentam sempre esta dimensão onde as evidências são deduzidas da observação e da invenção de modelos de compreensão, estes modelos nos aparecem como dados a posteriori.

Em música, até o advento do século $\mathrm{XX}$, as teorias também se substanciam como modelos a posteriori de uma prática já solidificada, encontrando um exato paralelo nas ciências, que lançam mão de modelos que possam explicar a observação de determinados fenômenos naturais, mesmo que por hora não possa ser comprovada a teoria $^{41}$. Nestes casos, a teoria nasce necessariamente no âmbito da recepção das obras ou dos movimentos artísticos, e são inexoravelmente escolhas estéticas e mesmo ideológicas dos teóricos, posto que qualquer aspecto analítico da poética, mesmo que busque essencialmente o texto musical (como se isso fosse possível), estará irremediavelmente condicionada ao contexto da recepção da obra.

\footnotetext{
${ }^{41}$ Caso de Ptolomeu e seu grande modelo de explicação para o funcionamento do Universo (baseado na cosmologia aristotélica) que, embora se adequassem bem às observações, obviamente não condizia com a realidade do funcionamento dos sistema solar. Na ciência, esta dinâmica de substituição de um modelo por outro mais pertinente é a condição para seu desenvolvimento; mas não se pode esquecer que, diante da atual crença na ciência, mesmo um filósofo como Kierkegaard pode continuar atual: "(...) De todas as ciências, a Ciência Natural é a mais insípida e para mim existe algo de divertido em pensar que ano após ano se torna trivial aquilo que uma vez surpreendeu, mas esta é a sorte das descobertas situadas na má eternidade" (Sören Kierkegaard em Eine Literarische Anzeige, 1846).
} 
Dá-se assim, do ponto de vista filosófico, uma conexão temporal das várias recepções, cabendo ao filósofo da música a difícil tarefa de decifrar todo este amálgama. Em tempos mais remotos, a compreensão desta faceta da música (enquanto ciência) não representava um problema, por isso, após o advento das vanguardas do século $\mathrm{XX}$, e a substituição paulatina do músico pelo teórico ${ }^{42}$, a ideia da música como ciência é uma mera definição ideológica de campos. A música é a imanência de uma ciência, enquanto as epistemologias da ciência da música moderna, apenas são a assertiva de uma certa ideia, muito específica, do que a música deve ser no âmbito científico. Isto posto, é necessário lembrar que os gregos antigos, em sua multíplice concepção da música, já postulavam uma cosmologia ${ }^{43}$ que pressupunha uma indissociável relação entre música, astronomia/astrologia e matemática, visão esta com uma duradoura influência subliminar ao longo da história, justamente num pitagorismo ressemantizado inúmeras vezes,e cuja pregnância pôde aparecer explicitamente muitos séculos depois numa obra tão importante quanto Harmonicemundi ${ }^{44}$ (concluída em 1618) do astrônomo Johannes Kepler. Apontando neste sentido é que Jean Molino afirma, sobre o legado pitagórico, que "a música será assim, como a geometria, o mais antigo exemplo de física matemática, isto é, de relacionamento do número com o mundo dos fenômenos. [Ela] constituiu-se em ciência puramente teórica (...)" (MOLINO, s/d:112). Aliás, esta dimensão se manterá numa educação liberal que consistia no trivium (retórica, gramática e lógica) e quadrivium (geometria, aritmética, música e astronomia), que incluía uma introdução à física aristotélica e à geometria euclidiana. Na música, as teorias como as que orientaram as composições vocais no século XIV ou mesmo a sistematização da tonalidade em Rameau no século XVIII parecem bons exemplos dessa concepção da criação de modelos teóricos surgidos para

\footnotetext{
${ }^{42}$ Abordarei mais profundamente este aspecto na terceira e quarta partes deste trabalho.

${ }^{43} \mathrm{Na}$ visão pitagórica, "as distâncias entre os planetas obedeciam às mesmas razões entre números inteiros satisfeitas pelas notas da escala musical. Ao girar em torno da Terra em suas órbitas, o Sol e os planetas gerariam uma melodia cósmica, o sistema solar se transformando em um gigantesco instrumento que ressonaria a música divina, a harmonia das esferas celestes” (GLEISER, 1997, p.56).

${ }^{44}$ As duas primeiras partes do livro lidam com o conceito de harmonia em matemática, sendo as outras três voltadas para música, astrologia e astronomia. Nesta obra, "Kepler ressuscitou a ideia pitagórica de harmonia, vestindo-a de uma linguagem geométrica mais sofisticada," usando-a como um princípio unificador capaz de descrever os movimentos celestes, mudanças climáticas, e mesmo o comportamento humano. Para o cientista “(...) essa harmonia é a ponte entre o ser e devir (...)” (ibidem, p.110).
} 
dar conta de explicar uma prática vigente, exatamente numa acepção que será cara justamente para as teorias cientificas ${ }^{45}$.

Muito embora esta lógica científico-matemática possa ter gradualmente se dissolvido nas pressões sociais que transformaram a música paulatinamente em mero entretenimento popular, ela pôde resistir ao subjetivismo romântico e se manter latente graças aos postulados teóricos, filosóficos e analíticos que alcançaram um alto grau de sofisticação no século XX. De qualquer modo, não devemos pensar que uma dimensão especulativa também não impregne a história dos postulados teóricos das ciências duras: muitas das chamadas mais "elegantes" teorias surgiram a partir especulações filosóficas e só se concretizaram tempos depois, após a comprovação de um dado número de evidências.

Assim, podemos concluir até aqui, que se as teorias especulativas lidam com problemas estéticos e filosóficos segundo um modelo dedutivo não-normativo que pode levar em conta todas as demais disciplinas, as teorias ditas cientificas em música se encontram próximas das disciplinas analíticas, deduzidas a partir de sistemas artesanais (operativos e normativos), se ocupando de assuntos de poética musical. Todas estas possibilidades trazem, a fortiori, a dimensão histórica como necessidade e possibilidade, que, dependendo da natureza da análise teórica, pode ser mais ou menos dependente da recepção (aspecto expressivo, histórico). Infelizmente, tende-se a considerar a dimensão expressiva ou especulativa como desnecessárias, originando o atual fetiche analítico do texto pelo texto, criando quase uma "produção em série" de modelos acadêmico-tautológicos. Umberto Eco ainda coloca estes problemas:

\begin{abstract}
(...) não há nada de menos científico do que pretender ignorar a presença de fenômenos ainda não inteiramente definidos. Sabemos, igualmente, que o fato de a estética contemporânea abandonar ou, mais rigorosamente, definir determinadas categorias como vagas e muito gerais, se deve precisamente a preocupações igualmente pedantes de cientificidade; e pela mesma razão renunciou à investigação de incontroláveis reflexos metafísicos para escolher como objeto de investigação a coisa, na sua estrutura verificável, e as suas relações com os fenômenos sociais, históricos e com os fatos psicológicos a que se liga. Mas o problema de uma atitude científica perante a obra de arte é precisamente um problema de equilíbrio, de renúncia a pretensões absurdas, de negação de qualquer ingenuidade verbal; (ECO, 1972, p. 51)
\end{abstract}

\footnotetext{
${ }^{45}$ Há mesmo um curioso senso, por parte de não especialistas, que coloca a música numa relação com a ciência. O musicólogo Charles Rosen aponta uma interessante colocação do filósofo e economista Adam Smith, que no final do século XVIII observou que "escutar uma bela sinfonia era como contemplar um grande sistema científico" (ROSEN, 2006, p.58).
} 
Aos poucos, o que vai se delineando é uma discussão de fundo que tem por base a crise do paradigma dominante, e a emergência de um novo. Malgrado a necessidade de reavaliação dos limites da ciência sejam bastante evidentes, no que diz respeito à noção de teoria em música, o que se vê é o oposto: o paradigma dominante é justamente o emergente, o que demonstra que a verdadeira discussão de fundo está oculta e reside mais na seguinte questão: como falar cientificamente de arte? Eco, novamente com a palavra, levanta o questionamento nos seguintes termos:

\begin{abstract}
Que significa falar "cientificamente de uma obra de arte"? As respostas são várias e não se excluem entre si: em primeiro lugar, o discurso científico poderia consistir numa exposição de fatos históricos conexos com a obra (realizada no dia tal, pelo artista tal, usando material, etc.); poder-se-iam ainda apresentar os documentos comprovativos do nascimento da obra, esboços, pontos de partida, redações preliminares; por fim, poder-se-iam catalogar os juízos que os outros fizeram da obra. Em todos estes casos o discurso seria "científico", porque se basearia em dados de fato controláveis, mas não seria um discurso sobre a obra. É evidente que a obra é algo mais do que o ano do seu nascimento, do que os seus antecedentes e do que os juízos formulados ao seu respeito. E o modo como algo mais é habitualmente explicado quando se fala de uma fundamental "abertura" ou "ambigüidade" ou "polissemia" de uma obra - entendendo-se com isto que a obra de arte constitui um fato comunicativo que necessita ser interpretado, e portanto integrado, completado por uma contribuição de quem a frui. Contribuição que varia com os indivíduos e as situações históricas e que é continuamente medida por referencia ao parâmetro imutável que é a obra enquanto objeto físico. Diremos então que "falar cientificamente de uma obra de arte" pode significar toda uma série de operações diferentes e complementares, cada uma das quais representa um nível particular de fruição. (ibidem, p. 49)
\end{abstract}

Como apontamos anteriormente, os limites em que as teorias de diferentes naturezas se apartam uma das outras são muito tênues, o que se agrava graças a essência poliédrica da música, possibilitando que uma reflexão de natureza filosófica (como a que estamos realizando) se debruce sobre problemas de outra natureza, que se nos dá na possibilidade da afirmação de que a música é, dentre todas as artes, a que mais tem afinidade com a ciência, mesmo com aquelas que denominamos ciências abstratas ou duras. Se como vimos, historicamente as teorias científicas - e agora incluímos as musicais - podem aparecer em sua maioria como teorias a posteriori, surge o problema filosófico inevitável residente na discussão sobre o papel do observador em relação ao objeto observado. Esta questão parece ser central para compreensão da posição meta que o cientista e a ciência passaram arrogantemente a pretender ${ }^{46}$ na possibilidade de uma "neutralidade" científica com relação ao objeto estudado.

\footnotetext{
${ }^{46}$ Os postulados teóricos da moderna física quântica apontam justamente para esta impossibilidade, justamente quando ao observador se torna impossível observar uma partícula (que pode se comportar
} 
No entanto, o século XX viu a ciência ter de lidar com a impossibilidade da sustentação dessa posição meta graças às descobertas relativas ao universo quântico, à impossibilidade de um determinismo científico como o da física clássica, à admissão de um princípio de incerteza desvelados pelos novos modelos de observação. Esta impossibilidade de que o observador se mantenha numa posição neutra em relação ao objeto estudado se evidência na arte da música se examinarmos algumas de suas peculiaridades, e torna toda a "febre" científica no campo da arte ainda mais paradoxal, posto que mesmo a ciência mais elaborada e sofisticada do século XX e XXI dá margem a um novo paradigma científico, que não deve se concentrar mais nos modelos dominantes do positivismo. Dito isso, vemos que as modernas teorias analíticas em música, e a moda vanguardista de ciência e tecnologia, na realidade, não estão postulando suas hipóteses a partir do paradigma emergente, e sim do antigo e exaurido paradigma dominante. Isso se revela quando observamos que a realidade implícita na produção de obras de arte vai além desta compreensão de teoria como algo necessariamente dado a posteriori, cujo principal logro ao longo da história - e deveria sê-lo ainda nos dias de hoje - é servir como suporte para a compreensão da realidade poética da obra, do seu sistema artesanal, servindo finalmente à uma reflexão de outro cunho teórico, porém mais desejável, das ciências humanas, capazes de abranger mais elementos - onde a análise matemática da obra é apenas mais uma - a uma rede sistêmica mais ampla, capaz de incluir um pensamento sociológico, histórico e estético.

A partir do século XX, o pensamento, e porque não dizer a estética da vanguarda legou uma novidade (que não é tão novidade assim): a possibilidade de que a obra de arte possa ser inventada a partir de teorias a priori. São muitos os exemplos de modelos de criação propostos como possibilidade operativa in abstractum, como sistemas artesanais, que são modelos operativos da própria obra porvir, e que sem dúvida podem ter deduzidos de si modelos teóricos para análise da própria obra produzida. Assim sendo, vemos que um quadro conceitual ainda mais interessante surge quando pensamos

como onda) sem afetar o comportamento do objeto observado. O principio da incerteza, um dos mais radicais fundamentos teóricos mais modernos também nos leva a questionar sobre a possibilidade conceber as teorias sem absolutos, o que na música, pode corresponder às possibilidades de análise com múltiplos sistemas teóricos - compatíveis com a poliestilística das obras atuais. Mas, melhor ainda, seria se em vez de teorias analíticas, os múltiplos sistemas teóricos fossem de múltiplas naturezas sociológica, filosófica, analíticas - se imbricando conscientemente, mantendo seus postulados, mais promovendo a discussão de campo. 
nestas possibilidades de teorias postuladas a priori $^{47}$. O que a princípio pode parecer contrassensual na realidade atina diretamente com a realidade musical, e encontra um paralelo vivo que passou a sustentar a ideia de música enquanto esta certa noção específica de ciência, que tem a ver com o paradigma dominante. Prática comum entre muitos compositores do século XX, a invenção de teorias que pressupõem a posterior invenção da própria obra levanta algumas questões fundamentais para nossa reflexão, principalmente para uma especulação filosófica em música: trata-se, neste caso, de teorias de fato ou da própria obra ${ }^{48}$ ? Afinal, se a teoria já é a invenção da lógica que produz a legalidade interna da obra, já não seria ela então, não uma teoria, mas a própria obra? Outro problema: se uma teoria científica deveria necessariamente ser um modelo inventado para interpretar dado fenômeno a partir da observação, então a obra - ainda não inventada - não pode ser "observada", mas a sua teoria já existe. Este paradoxo, de saída, já não pode demonstrar que a ideia de tratar com teorias a priori, que legalizam em um plano prévio toda a obra musical, não seria algo empobrecedor dessas possibilidades que a obra oferece no próprio fazer?

Muito embora a estética de Pareyson tenha como grande contribuição a sua distinção entre poética e estética, demonstrando que a essência não-normativa da estética é o que a diferencia da poética, me atrevo aqui a deduzir dela um postulado normativo, aventando a hipótese de pensarmos por um momento na estética como em poética em prol dessa reflexão: da quase aporia pareysoniana não seria possível deduzir que as possibilidades formativas da obra não seriam tão mais ricas quanto mais se deixasse o por fazer e o modo de fazer dados no ato de compor "jogarem" na obra tanto quanto o planejado (neste caso imaginado) pelo compositor previamente? Esse equilíbrio entre o a priori e o ato da invenção não seria desejado? Ou talvez esse processo, ao contrário desta hermenêutica que busca uma certa ideia de progresso, que digere a ideia de que o progresso é o progresso da razão, portanto desta mesma hermenêutica, possa na verdade ser o progresso e a culminância de um processo de abandono, e de emanação de uma vocação, a vocação para o metalinguístico.

\footnotetext{
${ }^{47}$ Um exemplo paradigmático reside na invenção do serialismo dodecafônico. Neste caso, Schönberg lança mão de um modelo que não só pressupõe a invenção de uma obra específica, mas serve como modelo operacional - ou sistema artesanal - para toda uma poética.

${ }^{48}$ Lutoslawski fala do risco de se compor exemplos de teorias (NORDWALL, 1968).
} 
Para Ferreira Gullar, sim. Ele, inventor de poemas, não hesita: "eu decido como vou fazer um poema a partir do elemento que o desencadeia ou provoca" (JIMÉNEZ, 2013, p. 234).

De qualquer maneira que se pensar respostas para estas perguntas, uma coisa é certa: há a urgente necessidade de um paradigma novo também para música, onde é evidente que não há posição "meta" para o analista, e a manutenção de uma certa ideia antiga de ciência positivista parece, em termos de arte, e especificamente em composição musical, ser empobrecedora e limitadora.

A partir da reflexão tecida até aqui, não fica difícil lançar mão de algumas categorias passíveis de serem pensadas para a formulação de um paradigma emergente para a teoria musical, que pode orientar tanto uma possibilidade relacional da estética musical com a ciência - no sentido de pesquisas mais objetivas e verificáveis - quanto para poética musical, ambas hegemonicamente contaminadas pelos pressupostos neopositivistas oriundos do pensamento de vanguarda. Antes, vale lembrar que toda esta problemática não se limita ao universo das teorias científicas. Do ponto de vista filosófico pode-se dizer que este problema se encontra latente também nas teorias de natureza especulativa ou histórico-sociológica; todo e qualquer observador já se encontra de maneira incontornável num complexo de inter-relações que pressupõe uma cadeia de re-significações e recepções de fatos históricos, de obras que dialogam entre si, e das recepções destes. Neste sentido, creio que ninguém pôde ser mais preciso do que Umberto Eco; analisando justamente a cientificização da estética, ainda nos anos 50, Eco, desta vez procurando um exame mais prescritivo do problema, vale ser citado na íntegra, sobre um possível caminho a seguir (ou evitar!), para uma outra estética:

1. Observar a coisa naquilo que ela especificamente é, isto é, objeto produzido por um homem que lhe apôs o carimbo evidente que é a maneira como a produziu; 2. Procurar não reduzir a observação a uma apreciação inexpressiva (um som indistinto) ou a um juízo demasiado subjetivo ("isto agrada-me") ou a termos demasiado vagos e polivalentes ("como é belo!"), mas esclarecer em termos comunicantes a impressão própria a respeito da obra; 3 . Ver se a esta impressão, corretamente comunicada, correspondem no objeto elementos que justifiquem o consenso dos outros, e que levem a presumir que o seu produtor procurasse, efetivamente, suscitar em todos uma impressão fundamentalmente análoga; 4. Pôr em relevo a maneira como se chegou a esta conclusão, com que intensidade, à custa de que dificuldades e com base em quê; 5 Querendo ir mais além: verificar que estes elementos, assim destinados a suscitar uma impressão, apresentam, na sua disposição meditada, uma estrutura bastante complexa, derivada da coordenação de vários níveis e estruturas menores, admirável, porque formalmente satisfatória e praticamente eficaz (enquanto comunicante). (ECO, 1972. p. 50) 
Os problemas, aqui analisados nesta dupla relação do artístico/filosófico com o cientifico, encontram razões para sua existência: embora seja possível analiticamente no que diz respeito a obra - transcender o caso particular da obra analisada em busca de bases para construção de modelos composicionais que pretendem ser universalmente válidos, tarefa condicional das ciências duras, o mesmo é só relativamente válido para obras da arte musical, uma vez que a obra de arte ainda apresenta uma real dificuldade quando confrontamos um sistema artesanal que serve uma poética "geral", com o uso individual que os artistas fazem do sistema. Se podemos considerar as coisas dessa forma, então, em qualquer discurso sobre obras de arte, não haveria de antemão o problema da possibilidade de se postular modelos universalmente funcionais, uma vez que o que se nos mostra de fato, é uma dialética entre o universalmente válido versus a poética individual e (quase) intransferível do artista? Aparentemente não. Se em ciência o "universalmente válido" se tornou na descrição relativa de um modelo para realidade, em arte, essa dimensão é ainda mais imensurável: não há possibilidade de pensar sistemas fechados, uma vez que

Sistema e realização do sistema se confundem em um só facto, a obra, a qualquer nível que a consideremos: desde a obra solitária, isolada das produções vizinhas do compositor, à obra completa de um compositor ou ao conjunto das obras de um período delimitado da história da música. Só há "sistema" tonal nos fabricantes de tratados de harmonia, cujas regras "gramaticais" são efetivamente regras estilísticas: A sua aplicação não permite realizar obras reconhecidas como tonais de Monteverdi a Debussy, mas obras que ninguém, mesmo na época acadêmica, pensou escrever (...) (NATTIEZ, s/d: 36)

No entanto, o que pode parecer um problema incontornável na abordagem sobre obras de arte, como vimos, também apareceu como um problema incontornável para ciência: justamente a possibilidade do universalmente válido, melhor equacionado em um realismo dependente do modelo. Assim sendo, podemos concluir que em arte, tais problemas acabam por se corresponder à possibilidade de uma análise histórica da poética (aspecto expressivo, em Pareyson) versus uma compreensão em que a arte se dá na singularidade da obra (aspecto revelativo, estético em Pareyson). Mais ainda: um sistema jamais será suficiente para um exame absoluto da obra, pois também estará presente a dialética entre a tentativa da análise "neutra" do texto pelo texto (aspecto da poética) na busca da dedução de modelos normativos válidos para compreensão de todo 
um conjunto de obras versus o jorro de significados dados a partir das múltiplas recepções.

Como opção, já que um paradigma emergente em música deve levar em conta a impossibilidade de qualquer metadiscurso, o que resta é assumir o princípio de incerteza das "interpretações titubeantes", mas equacionáveis dependendo do nível de reconhecimento das limitações dos próprios instrumentos escolhidos; afinal, como afirma Eco, "há ciência e ciência, nem todas as ciências classificam insetos, quem tem vocação para classificar insetos não se deve ocupar de recolhas poéticas; representaria muito mal o papel de cientista" (ECO, 1972, p. 51).

Dentro do quadro conceitual que viemos delineando até aqui, essa pregnância de um modelo científico-musical que nasce como uma espécie de nova metafísica da música a partir do início do século XX, mas que, como vimos é apenas a pregnância da antiga metafísica pitagórico-platônica, nada mais é do que a pressuposição de teoria musical tornada legítima apenas enquanto disciplina analítica dentro de uma lógica empirico-matemática.

Essa é lógica que paulatinamente aparece como paradigma dominante de uma certa forma de compor a partir de teorias a priori, o que delineia aquilo que eu chamei de hermenêutica da consistência. Essa hermenêutica é justamente o paradigma dominante tomado como o emergente. Uma emergência da manutenção do cânone surgido da estética musical em seus inícios (as luzes do iluminismo nem sempre iluminam de fato) e posterior desenvolvimento no século XIX, que buscou legitimar uma teleologia de matriz austro-germânica e re-significativa de um novo pitagorismo.

Vista assim, temos que o pensamento de vanguarda (dentre as várias vanguardas) oriundo desta matriz e que passa obrigatoriamente por Darmstadt, legitimada dentro de uma ideia de progresso da música (que é a mesma ideia de progresso da ciência) é subjacente a uma noção de "redenção" da arte pela sua cientificidade. Ora, esse não seria o vício maior da compreensão da arte enquanto esta certa ideia antiga de ciência, tão pregnante na academia? (penso em termos de Brasil, mais isso talvez seja paradigma nos principais centros do mundo, haja vista a preocupação de Nicholas Cook em apontar estas problemáticas). Essa metafísica que legitima a música a partir do reconhecimento de sua arquitetônica, o que aparentemente resolve o problema da aceitação acadêmica da música pela elevação de seus pressupostos matemáticos, não residiria justamente no paradoxo de um reforço de uma materialidade que se consubstancia em uma paradoxal idealidade na concepção da obra? 
Em outras palavras, o que temos é a tomada da música a partir de sua formulação abstrata, o que não seria demais dizer que é apenas uma nova formulação para o absoluto.

De fato a música pôde perder a sua aura, o culto de sua transcedentalidade; a possibilidade de sua verificação científica pôde, aparentemente, descrever a sua materialidade - ela seria um projeto arquitetônico materializado; no entanto, não seria demais pensar que essa absorção de uma visão equacional, algorítmica, de teorias apriorísticas delineadoras, de determinismo absoluto não teriam gerado uma hipertautologização em detrimento da inventividade, da fantasia, da possibilidade de diálogo com o incerto, enfim com aquilo de mais essencial residente na inventividade humana? Seriam essas questões meramente retóricas ou as proclamações de 'morte da arte' apontam para a necessidade de repensar outros caminhos para a arte e o pensamento sobre arte?

Enquanto as estéticas de outras artes puderam apontar os problemas imanentes a uma inscrição do homem sob o signo do nada, refletidos em uma vontade de aniquilação que levou não só à desintegração do sentido mas também à eliminação da própria obra, em música, esta conexão com os paradigmas dominantes da ciência, esta ansiedade pela consistência, não teria feito com que, para além da ausência de sentido essa já parte da natureza da obra musical - se pudesse reproduzir "a barbárie tecnicista, a barbárie abstrata do cálculo que ignora o humano do ser humano, sua vida, seus sentimentos, entusiasmos, sofrimentos" (MORIN, 2011, p.41)? Penso que não são apenas perguntas retóricas e nem constatações conservadoras que atentam contra a "evolução" da música. São questões urgentes, que trazem consigo considerações sobre o próprio afastamento do humano da obra, seja substituído pela máquina que a executa, seja excluído da possibilidade de compreensão sobre aquilo que dela emana.

A perda do mundo na obra não é só a perda de um mundo idealizado. Ela também é a perda do mundo material, do contato com este real que produz, que é libertado pela obra. Ou seja, na obra, material e ideal podem ser vistos como indissociáveis.

\subsection{Algumas conclusões}

Se minha intenção é apontar caminhos para uma outra estética da música nova, da música de hoje, penso que a partir dessa emancipação do pensamento teórico musical 
com relação ao paradigma dominante da ciência, e com o lançamento de um modo de pensar as próprias teorias científicas dentro de novos paradigmas, mesmo que ainda emergentes, será possível uma recolocação do papel da estética musical enquanto teoria da arte, bem como reestruturar, no ambiente acadêmico, a compreensão musical dentro de um espírito liberto da dogmatização vanguardista, conectando-a aos paradigmas emergentes das ciências, onde uma rede de discursos interrelacionais flexibiliza uma possível nova divisão epistemológica que não privilegie a lógica quantitativa e a objetividade pseudo-verificável, mas que também não embace as fronteiras entre as disciplinas, antes, cada uma em seu campo, forneçam os dados para a verificação estética e filosófica, mantendo uma rede que possa, por analogia, ser tão poliédrica quanto é a natureza da música. Para concluir, a sugestão de Umberto Eco pode ser bem vinda. E ela foi lançada há muitas décadas...Mas, naquilo que pretendo construir com esta tese, já se pode dizer que há uma base:

\begin{abstract}
(...) a estética é, sem dúvida, uma disciplina capaz de criar métodos e instrumentos de investigação próprios, mas não é uma ciência exata - ainda que pode valer-se de certas conclusões das ciências exatas (...): e deve, portanto, adaptar instrumentos que lhe permitam trabalhar no não-exato, no não-redutível-à-quantidade, em suma, numa experiência em que entram em jogo quer fatores físicos verificáveis, como os materiais artísticos e os processos construtivos, quer fatores subjetivos variáveis por definição, como as reações psicológicas e as concreções históricas do gosto, de acordo com as quais os mesmos fatores físicos verificáveis são organizados (e carregados, assim, de intenções especiais que escapam à verificação quantitativa e à interpretação unívoca) (ECO, 1972, p. 56).
\end{abstract}

Se postularmos um quadro - com o cuidado de que suas definições sejam apenas hipóteses - onde, a estas colocações de Umberto Eco se juntem as noções terminológicas de Olga Pombo, justamente aquelas em que as noções disciplinares recebem o imperativo do próprio objeto, sendo o sujeito e sua vida responsáveis pelo estabelecimento das relações sem que haja categóricos a priori, e a distinção realizada por Pareyson no seio da própria estética - aquele que a define a partir da distinção não dicotomica entre poética-estética, que localizei no seio de sua filosofia geral a partir de uma outra distinção (filosofias expressivas-revelativas), temos a possibilidade de realizar algo talvez desejável: conceber uma delimitação de campos, sim, cada qual postulante de suas próprias epistemologias e sistemas. Mas campos abertos não só para um caminhar pari passu, pluridisciplinar, mas para possibilidades de imbricação (interdisciplinares), sem o embaraço do reconhecimento de suas naturezas. Assim, rumo 
à superação da rigidez, possibilidades transdisciplinares podem aparecer como o seio mesmo das possibilidades de abordagem em filosofia da arte; em outras palavras, tomando o que Pareyson compreende ser a essência da filosofia, essa sua capacidade conectiva dos saberes de outras disciplinas. As evidências apresentadas por disciplinas aptas ao trabalho com parâmetros quantificáveis ou mensuráveis, mesmo nas ciências humanas não competem ao filósofo; antes, "compete-lhe construir uma teoria do sentido" e como se dá sua manifestação (como afirma Japiassu). Talvez a formula de Edgar Morin possa equacionar as coisas: "é preciso separar a ciência e a filosofia, é preciso separar as disciplinas, é preciso separar os objetos, é preciso separar os elementos...Sim, mas com a condição de que o que foi separado possa ser religado novamente." (MORIN, 2011, p.149). A estética, enquanto disciplina, poderá superar assim outras daquelas acusações de Talon-Hugon, apresentadas no início deste trabalho: se por um lado a multiplicação das aproximações às artes operadas pelas ciências humanas significa a dissolução do campo da estética nestas ciências, e aqui, a estética da música, devido a natureza mesma do objeto, tende a diluir-se nas possibilidades teórico analíticas, penso como uma possibilidade concreta um delineamento epistemológico que possa colocar a estética como cimento que conecte essas disciplinas, lhes conferindo, ao mesmo tempo, uma hermenêutica do sentido; e, levando em consideração ainda outra daquelas colocações: se o discurso filosófico sobre a arte é ilegítimo pois contesta-se à estética o estatuto de ciência rigorosa, "a pretexto de que seus objetos têm um caráter subjetivo", é porque ainda se tenta emprestar à estética e à filosofia uma legitimidade enquanto ciência (como se ela precisasse), e o que é pior, uma ciência realizada em torno de uma paradigma dominante, onde o observador ocuparia uma posição meta, e portanto livre da subjetividade. Ora, conforme procurei demonstrar até aqui, uma vez ultrapassada essa noção e assumido um paradigma emergente que possa colocar a ciência e o pensamento em conexão com a vida, essa acusação cairia na obsolência: vale relembrar, com Morin, que "a subjetividade não é inimiga do exame objetivo das realidades", sendo necessário tornar-se "um sujeito/ator crítico" (MORIN, 2011, p.142). E como colocação final, poderíamos ir mais adiante: se invertermos a proposta e obtivermos algo como uma pregnância da arte nas ciências, demonstrando o quanto a inventividade dos processos artísticos poderiam contribuir para as investigações duras, talvez as ciências poderiam ter um novo fôlego renovador. Essa ideia, de saída, reside no que entendo por interdisciplinaridade. Mais: ela está relacionada diretamente à superação da ditadura idealista que foi sempre o cerne da 
disciplina estética, mesmo depois de sua organização epistemológica mais moderna essencialmente croceana.

Finalmente, concluo esta etapa da reflexão sobre os problemas estéticos que envolvem o conceito de teoria e ciência criando uma ponte com os assuntos vindouros, especialmente aqueles já esboçados em diversos trechos desta exposição: as questões que envolvem essa reflexão sobre os paradigmas científicos e as teorias da música.

Como procurei demonstrar, não é difícil vincular parte das formulações do pensamento de vanguarda aos paradigmas tradicionais das ciências. Na realidade, a essência do pensamento musical de vanguarda - malgrado suas diversas contribuições criou a falsa noção de uma ruptura com o passado, ao vincular suas teorias a uma noção de progresso através do atrelamento ao arcabouço da "verdadeira" ciência, o que corresponde, na estética musical, á criação de um cânone baseado da ideia de consistência. Na realidade a ruptura, neste sentido específico das ciências, apesar de ocultas em suas emanações de progresso tecnológico, não ocorreu. Houve, pelo próprio radicalismo do projeto vanguardista, uma visceral conexão com uma velha ideia de ciência - a positivista - cujo agravo se estabelece pois trata-se de um problema de essência. A essência da velha vanguarda, (travestida sempre da necessidade do novo radical em música, e que se mantém militante em sua delimitação de campos), possui uma compatibilidade com o que há de mais velho (mesmo que admirável) nas ciências: um deslumbramento excessivo do cientista pela própria descoberta - e mesmo por si próprio; uma pretensão de universalidade; a ilusão lançada pelo dogma da criação da linguagem original e consistente. Esta compatibilidade de essências, é evidente, é antiga:

Esta preocupação em testemunhar uma ruptura fundante que possibilita uma e só uma forma de conhecimento verdadeiro está bem patente na atitude mental dos protagonistas (cientistas), no seu espanto perante as próprias descobertas e a extrema e ao mesmo tempo serena arrogância com que se medem com os seus contemporâneos. Para citar apenas dois exemplos, Kepler escreve no seu livro sobre a Harmonia do Mundo publicado em 1619, a propósito das harmonias naturais que descobrira nos movimentos celestiais: "Perdoai-me mas estou feliz; se vos zangardes eu perseverarei; (...) O meu livro pode esperar muitos séculos pelo seu leitor. Mas mesmo Deus teve de esperar seis mil anos por aqueles que pudessem contemplar o seu trabalho" (SOUSA SANTOS, 1988, p.3)

Os famosos dizeres de Schönberg, deslumbrado e estupefato com a sua descoberta de um sistema teórico que pudesse ser hegemônico pelos "próximos 100 
anos", mantendo a "supremacia da música germânica" - algo que, ao estilo dos profetas hebreus, ele previu - são exatamente consubstanciais em natureza. E, já que começamos esta parte com um achado de Borges, do século XVII, para ilustrar a minha busca, penso ser justo concluir com ele:

Un hombre se propone la tarea de dibujar el mundo. A lo largo de los años puebla un espacio con imágenes de provincias, de reinos, de montañas, de bahías, de naves, de islas, de peces, de habitaciones, de instrumentos, de astros, de caballos y de personas. Poco antes de morir, discubre que ese paciente laberinto de líneas traza la imagen de su cara.

em El Hacedor

(BORGES, 1998 [1960]) 
PARTE III

POR UMA DEFINIÇÃO DE ARTE PARA A CONTEMPORANEIDADE 


\section{Parte III - Por uma Definição de Arte para a Contemporaneidade \\ É possível uma definição de arte? É possível uma estética musical materialista?}

\section{Prefácio à Parte III}

- Rumo a uma definição de arte

Os próximos passos deste trabalho vão na direção de discutir mais especificamente alternativas para uma estética que seja consubstancial à pluralidade da música e da arte atual. Pensando nos problemas epistemológicos que puderam ser levantados até aqui, se é impossível o lançamento de um quadro acabado de epistemologias do campo da estética, já foi-me possível constatar um quadro de crise associado ao modo como o pensamento da vanguarda, na música, se concretizou segundo um paradigma dominante da ciência, e apresentar possibilidades de superação desta crise, que, refletida nas possibilidade da disciplina, se mantêm como reflexo da manutenção de pressupostos desgastados mas dominantes.

Foi possível examinar também o modo como esta situação estabelecida, no caso da música, remonta à construção de um sentido teleológico sob os auspícios da própria disciplina estética, desde seus inícios, e o modo como seus vícios puderam se manter vivos na modernidade, sendo pregnantes mesmo na forma como a música pode se relacionar com uma velha ideia de ciência.

Se até agora minha intenção foi levantar problemas no sentido de situá-los e percebê-los por um determinado ângulo propondo uma abordagem alternativa, procurarei agora compreender de que forma a estética tem se imbricado e como poderia se relacionar com as manifestações modernas.

Por isso buscarei veicular alguns conceitos em estudos sobre a natureza da música e a possibilidade de uma definição da arte para a contemporaneidade. É orientado neste sentido que procurarei estabelecer uma relação entre os desdobramentos do pensamento sobre a arte moderna e as estratégias de manutenção do cânone musical no século $\mathrm{XX}$, buscando uma teoria de sentido que o explique mas que seja já alternativo a ele.

Nas muitas análises realizadas até aqui, pode ficar claro que minha pretensão se relaciona não só em pensar os problemas da estética a partir das crises e confusões epistemológicas que a circunda. De fato, trata-se de investigar em que medida uma 
estética musical pode ser retirada de uma situação de crise uma vez que o seu próprio objeto fez da crise e do nada, manifestação poética; e fez desta manifestação um paradigma dominante. Por isso, esta terceira e quarta partes deste trabalho são ensaios em torno do problema de definir esse objeto de forma alternativa ao dominante, percebendo nele não só o que pode ser 'novo' - um novo 'outro' - mas o que pode ser recuperado e que foi perdido. É neste sentido que se orienta minha busca por uma definição de arte: em primeiro lugar é preciso uma estética musical que, em sendo nãoprescritiva, seja anti-canonica, e para isso, é preciso que ela assuma uma perspectiva crítica de seus próprios caminhos e de seus próprios vínculos com a modernidade. É o que eu tenho tentado realizar desde o início. Então, esta definição deve estar afinada com as possibilidades da modernidade.

Se a crítica das epistemologias e o levantamento de possibilidades emergentes já nos mostram como talvez as coisas possam se realizar, tentarei aplicá-los então no sentido da recuperação do que foi perdido na modernidade. É neste sentido que pretendo tentar uma definição de arte.

- Rumo a uma possibilidade estética

Já na parte final da introdução deste trabalho, levantei alguns perigos preliminares relacionados à radicalização e extremização de uma compreensão estética, no sentido de um materialismo e um idealismo limites. Até agora, optei por não aprofundar em que medida mais exatamente se daria um materialismo ou um idealismo. Apresentei esses conceitos, já utilizados ao desgaste e ressemantizados de várias formas, sempre ligados aos autores, que identificam a tendência da estética a um idealismo como um de seus maiores problemas. Aliás, essa é uma das acusações demonstradas em Talon-Hugon.

Optei por deixar que o próprio uso corrente dos termos neste trabalho indicasse um caminho para minha compreensão, chegando à duas conclusões: em primeiro lugar, idealismo, no caso das artes, aparece quase sempre identificado com uma tendência ao mundo da obra. Em quase todos os autores (especialmente Eco, Pareyson e Formaggio), aparece identificado com a hegemonia da estética de Benedetto Croce e demais metafísicas da arte; em segundo lugar, para evitar tornar natural o vínculo do termo 
materialismo a parâmetros redutivos que o associem mecanicamente à certas manifestações expressivas - como o materialismo histórico, por exemplo -, criando uma lógica falha: estética, filosofia (idealismo) versus sociologia, antropologia e outras ciências humanas (materialismo).

Uma vez que me propus a uma verificação epistemológica, especialmente no debate sobre os vínculos entre arte e ciência, foi possível vislumbrar algum delineamento epistemológico: a partir de Supičić e Pareyson pôde-se perceber em que medida uma epistemologia deve ser consubstancial à característica dos objetos e campos aos quais ela "empresta" modos de operação, e como esses modos devem ser, ao mesmo tempo, fundamento e substância da disciplina.

Assim sendo, em estando claro as diferenças fundamentais entre os campos de estudo - entre a estética e a história, por exemplo - seria possível então uma relação disciplinar cada vez mais ampla. Algo que me parece fundamental para uma nova estética, como pretendo demonstrar nesta tese.

Mas, se ao resgatar os conceitos fundamentais desde o alvorecer da estética, discutindo suas distorções, a ideia de que preceitos metafísicos se mantêm ainda pregnantes; se a escolha dos autores, principalmente da estética italiana, indicam a possibilidade de superação da 'ditadura idealista' na estética, é porque reconheço a necessidade de que a estética se equilibre: obviamente materialismo e idealismo não podem ser tomado como puros conceitos; por isso tomo-os como metáfora, reconhecendo a necessidade de uma estética mais pregnante de materialismo. Mas em que sentido são metafóricos?

Na medida em que o idealismo apareceu, inadvertidamente, ligado a uma noção de autonomia e mundo da obra, penso que um materialismo se relacionaria ao mundo social do homem, ao mundo da vida. Mas como encontrar esse 'materialismo' a partir da natureza da estética, segundo vimos apresentando até aqui, sem incorrermos no risco de "caímos nas generalizações sociológicas" (GULLAR, 2006, p. 82)?

Tanto Gullar, quanto Pareyson podem fornecer alternativas:

(...) ignorar os fatos sociológicos na produção artística também conduz a uma simplificação que, agindo em nome do específico estético, a esquematiza e empobrece. Esse tipo de análise formal, ou estrutural, que busca a imanência do texto a significação da obra é muito elucidativo, desde que conjugado a compreensão histórica e social (ibidem, 2006, 110). 
Vemos que Gullar se refere, no caso do "específico estético", mais ao que na música me refiro como o campo da análise, do uso das teorias analíticas; no entanto, a observação serve para o caso de um específico estético que pressuponha uma filosofia apartada do mundo material. Por isso, devo reiterar o que foi já apresentado.

Conforme já se pode concluir de minha abordagem epistemológica, a natureza da filosofia/estética deve se relacionar com as outras disciplinas segundo a lógica apresentada por Luigi Pareyson; nestes excertos, ele aponta não só a possibilidade de relação interdisciplinar como demonstra uma forma de trazer "o mundo social" condizente com a natureza da estética:

\begin{abstract}
(...) o pensamento, na medida em que não cede lugar à ação, tende a resolverse em pensamento empírico, que é precisamente a reflexão que caracteriza as ciências humanas como a psicologia, a sociologia, a antropologia cultural, a lingüística, a história da cultura, e assim por diante. Nada de mais legítimo do que estas ciências, quando elas permanecem nos seus limites, dentro dos quais são, efetivamente, insubstituíveis, cumprindo uma função importante, utilíssima para a própria filosofia (PAREYSON, 2005, p.33).
\end{abstract}

Se a natureza da estética é vocacionada para o mundo da obra, é certo que isso não precisa implicar num idealismo nas formas como ele se tem apresentado. Pareyson busca, condizente com o campo de atuação do que ele propõe como estética, que

\begin{abstract}
(...) a arte pode ser, ela mesma fundadora de socialidade. Não esqueçamos aqui o quanto a arte enobrece e eleva o ânimo e os costumes, a ponto de ser considerada, na sua pura qualidade de arte, como condição indispensável de civilização e fator importantíssimo da educação (...). Além disso, a arte tem um caráter eminentemente comunicativo (...). Ainda, a arte realiza o mais difícil conceito de socialidade, porque ela fala a todos, mas a cada um de seu modo, e assim assegura uma universalidade através da individualidade e institui uma comunidade através da singularidade. (...) Que a arte é fundadora de socialidade fica testemunhado pelo fato de que ela não pode passar sem o público, não tanto no sentido de que dele dependa ou tire sua norma e conselho, mas antes no sentido de que o prevê e o invoca, o suscita e o arrasta (PAREYSON, 1997, p. 122).
\end{abstract}

Assim sendo, minha busca será, então, por um caminho que aceite essa vocação da estética para o mundo da obra, mas que perscrute um materialismo a partir de sua própria natureza enquanto disciplina.

É neste sentido que orientarei uma tentativa de definição de arte, para encontrar nela também uma formulação material. Se a arte é "fundadora de socialidade", é certo 
que a obra, por onde ela se dá, se revela a partir do que é material e humano, e na música é ainda mais latente, podendo servir como uma poderosa metáfora: o corpo ${ }^{49}$.

\section{Introdução aos problemas para uma definição de arte: a exigência do novo explícito}

No início deste trabalho foi-me necessário assumir pelo menos um pressuposto, um paradigma que pudesse pôr em perspectiva o caminho que uma nova filosofia da música contemporânea pudesse assumir; e esse paradigma é parte da possibilidade de uma construção de uma definição de arte que possa orientar uma estética para os dias de hoje.

Paradoxalmente ele não é um pressuposto novo, obviamente tomado como paradoxal apenas se este "novo" é visto a partir do modo como as vanguardas artísticas passaram a compreendê-lo; e mais: é um pressuposto que já orientou definições em outras épocas. Do ponto de vista em que eu o compreendo, "novo" pode ser tomado no âmbito de uma compreensão muito mais larga, e é a essa compreensão que faço alusão quando me refiro à necessidade de uma 'outra' filosofia da música como 'nova'. Esta compreensão está em conformidade com o que assevera Ferreira Gullar, quando diz que "(...) a exigência do novo explícito tornou-se um fator decisivo na produção e na avaliação da arte contemporânea" (GULLAR, 2006, p.13) deve exigir uma contraposição que considere o novo como

\footnotetext{
${ }^{49}$ É-me inevitável negar também a influência do filósofo e polemista Michel Onfray $(2008,2014)$ na escolha do corpo como guia de uma investigação que aproxime a música de um 'materialismo'. sendo ele uma das grandes novidades no mundo da filosofia, tem tentado trazer à lume uma história da filosofia que se coloca contra a história da filosofia. Segundo ele a história canônica é apenas uma reedição $a d$ nauseum de um idealismo de raízes platônicas que através dos tempos não mediu esforços na defesa de seu próprio campo, obscurecendo e até mesmo tentando eliminar qualquer possibilidade de legitimação dos materialistas e sua genealogia filosófica ao longo dos séculos. O registro segundo o qual Platão jamais cita Demócrito, com a exceção negativa de que ele não havia comparecido ao enterro de Sócrates, e teria tentado eliminar toda a possibilidade de literatura dos materialistas, seria o paradigma e a metáfora desta situação. Nos vários volumes de sua Contra-História da Filosofia e em seu Tratado de Ateologia, Onfray não titubeia em uma interpretação baseada numa dicotomia entre o materialismo e o idealismo, numa trama que estaria atingindo hoje o seu ápice. O materialismo de Onfray, compreenderia os filósofos marginais, ofuscados pelos cânones idealistas consagrados, especialmente os hedonistas e cultuadores do corpo. A culminância desse materialismo se encontraria principalmente em um pensamento que nega a transcendência cristã, que nega todo o mundo que não é esse, do aqui, agora. O pensamento de Nietzsche seria representativo deste materialismo do corpo.
} 
Conjuntural e circunstancial porque uma coisa só é nova em determinado momento e em determinadas circunstâncias, uma vez que o que é velho num momento e em certo contexto pode ser novo ao se transferir para outro contexto (...). Decorre daí que o novo é efêmero, mesmo porque seria uma contradição, em termos, imaginar-se um novo permanente. Logo, o novo é uma qualidade externa (não essencial) às coisas, e a busca do novo pelo novo, uma empresa fútil (GULLAR, 1999, p. 41) ${ }^{50}$.

O paradigma que proponho tampouco é muito antigo; trata-se da ideia de que existe arte, e existem obras. Embora esta formulação seja aceite quase de forma natural e mecânica, a ideia de que existe arte e existem obras de arte não deve ser tomada de forma tão imediata assim.

Como aos poucos vim apontando neste trabalho, grande parte das abordagens atuais sobre arte realizadas pelas ciências humanas têm prescindido de qualquer ideia de arte ou de obra de arte, bem como as ciências empirico-matemáticas puderam resultar numa definição no sentido fraco de arte, baseada no que eu chamei hermenêutica da consistência para o caso da música, que, ao assumir a arte como uma coisa verificável enquanto sistema, em detrimento de seu caráter de pensamento, ou seja, filosófico, promove a impossibilidade de tomá-la como algo transcendente, ou que promova alguma transformação simbólica do mundo.

A admissão da existência da arte enquanto campo diferenciado da atuação humana não se reduz, na forma como a compreendo, ao modo como realizo e penso minha própria produção enquanto compositor; obviamente essa assunção é também relativa à minha experiência, no entanto, a ideia matriz deste ensaio, que reside justamente na possibilidade de retomada da legitimidade da estética para a música contemporânea, ou de uma nova estética, neste sentido de 'novo' não-categorial, convoca uma noção paradigmática para que o delineamento epistemológico da disciplina seja pensado de modo afinado com as tendências conjunturais de nossa época. Assim sendo, é neste sentido que penso que o que é relativo à minha experiência possa ser generalizável em alguma medida. Enfim, trata-se de verificar as possibilidades imanentes para o desenho de algo que possa orientar uma definição de arte por onde uma estética possa ser pensada.

Penso que, para a estética, o paradigma residente na ideia de que a arte existe e que ela se dá através de obras cujo saber diferenciado para sua realização é uma

\footnotetext{
${ }^{50}$ Schopenhauer fala algo nessa direção: "o novo raramente é bom, porque o que é bom só é novo por pouco tempo" (SCHOPENHAUER, 2006, p.61).
} 
necessidade, é consubstancial à possibilidade de um campo específico para o exame das coisas "a que os homens chamam ou chamaram arte".

Seria uma óbvia contradição postular um campo filosófico de estudo dos problemas da arte sem que seu paradigma mais basilar seja a existência do próprio objeto. A existência da estética depende da existência de uma definição que assuma este paradigma. Isso não significa que tomaremos esse pressuposto em sua forma acabada e desgastada pelo uso, uma vez que, no já distante século XIV é que a ideia de 'obra' passa a ser fundamental para a compreensão do que é arte. Antes, pretendo alargar o seu alcance ao verificar a possibilidade de uma dialética interna que incorpore à noção de obra aspectos concernentes à sua possibilidade de investigação interdisciplinar que assuma metaforicamente a imbricação dialética tanto de um idealismo - que pode ser orientado pela consideração de uma distinção da arte em relação às outras coisas, tendente a um autonomismo e ao mundo da obra - quanto de um materialismo, que tem como tendência assumir as condições histórico-sociais como as mais determinantes para a compreensão da coisa-arte, como sendo ela algo de indiferenciado de qualquer outra coisa, tendente ao mundo da cultura.

Portanto, assumir um paradigma que leve em conta a existência da arte e das obras, no presente caso, não significa a exclusão da possibilidade de que a arte não se dê em outras formas. Ou, melhor explicado, significa que o conceito de 'obra' pode ser tomado numa conotação alargada que inclui aquilo que pode ser percebido como obra, libertando-se do paradigma da autonomia absoluta da obra de arte, o que configuraria uma antiga metafísica de cunho idealista, que tende a uma visão a-histórica e atemporal.

Minha intenção a partir de agora, é buscar uma definição de arte que possa ser alusiva à proposta epistemológica feita na primeira parte deste trabalho, propondo, inclusive, determinadas análises e estudos que possam servir de base para este "pensar arte e pensar música hoje".

Por isso iniciei esta segunda parte aludindo ao 'novo' neste sentido nãocategorial. Ou seja, uma nova estética musical não pode ser uma filosofia absolutamente nova, na medida em que não existe e nunca existiu uma arte e uma música radicalmente nova, e a tomada dessa ideia como verdadeira implica numa crítica às vanguardas.

A discussão de fundo, para aquilo que estou me propondo a pensar, tem a ver com afinar aquela proposta epistemológica para uma estética com o que seria o conteúdo conjuntural desta nova estética; algo que espero que ocorra ao longo desta dessa terceira parte, uma vez que, estrategicamente, pretendo discorrer sobre as 
possibilidades de definição tendo como alvo alguns conjuntos conceituais: notadamente, para a arte geral, o trinômio obra-coisa-evento; para a música, o binômio determinaçãoindeterminação será tomado como exemplo de um falso problema, que, aparentemente, é tido como a última grande discussão estética no âmbito da música contemporânea.

Para lograr sucesso em tal empreitada, espero ainda levantar questões acerca do cânone hegemônico, que orientou uma ideia de vanguarda, afim de aprofundar a discussão da primeira parte em torno daquela teleologia legitimada, justamente pela estética musical, que já foi exposta. Por fim, pretendo examinar todos estes problemas num sentido de que uma definição de arte possa partir do que chamarei como vocações da arte e do que a circunda. Tenho procurado assim me expressar, no sentido de não coagular conceitos a partir de noções apriorísticas que, de outro modo, poderiam ser tomadas como programas de arte.

Isso se dará no sentido de "(...) verificar se as definições gerais da arte elaboradas pelas estéticas são suficientemente compreensivas para se aplicarem também às novas noções surgidas no âmbito das poéticas" (ECO, 1972, p. 124).

\subsection{Arte e emancipação}

Podemos deduzir do pensamento do filósofo Dino Formaggio que a assunção do caráter de obra por onde a arte se dá, coincide com o início de uma tomada de consciência do artista deste aspecto da obra enquanto algo produzido através de um engenho: a partir do século XIV na Europa, abandona-se a consciência servil em direção a ideia de autonomia da arte ${ }^{51}$, dada a partir do início da conquista da autonomia do artista, não mais artesão, mas detentor de um conhecimento específico e singular. A

Assim sendo, finalmente, a arte passa a tomar consciência de seu próprio processo formativo. Neste sentido, a ideia tomista de ens creatum pôde assumir sua pregnância direta na ideia de obra de arte, e a arte como campo específico da produção

\footnotetext{
${ }^{51}$ (...) "só se emancipam deste estado de coisas no decurso do século XIV, quando se destacam do anonimato das grandes construções medievais do padroado eclesiástico (ainda operante em certas construções de catedrais góticas) e começam a trabalhar por conta própria, pois só então se tornam verdadeiramente senhores do seu próprio tempo e trabalho. É assim que, dos estaleiros de construção, se passa às Artes e às simples oficinas de arte, onde o próprio mestre trabalha e vive como patrão e se liberta (...)" (FORMAGGIO, 1976, p. 31).
} 
de obras de artistas passa a ganhar a sua eminência. Mais do que isso, inicia-se um longo caminho por onde a compreensão da arte enquanto ciência vai se manter latente, chegando ao ápice, como vimos, no século XX.

A própria ideia de ens creatum também lega uma noção que, desdobrada ao longo do tempo, culmina numa metafísica do 'novo absoluto', da singularidade e da autonomia. Pensando especificamente em termos de música, é notável que a ideia de compor (pôr junto) evidente nas primeiras manifestações da polifonia, passa a conotar essa consciência organizacional do material musical no advento da Ars Nova, quando um princípio sistemático apriorístico é aplicado à ideia de composição, dada justamente na aplicação da isorritmia como sistema artesanal.

É notável que a ideia de autonomia da obra de arte surja do mesmo bojo da descoberta da autoconsciência "científica" da obra. O processo de radicalização dessa autonomia, que aos poucos gerou as bases para uma metafísica da arte, em música, resultou em dois processos derivados: por um lado a crença na autonomia absoluta da obra de arte esteve relacionada à ideia, postulada no alvorecer da estética e desde então pregnante nela, como vimos, de absoluto na música, onde uma cada vez maior desconexão da obra musical do mundo material, ou seja, do mundo das coisas e dos sujeitos, pôde resultar numa relação intrínseca com todo idealismo das teorias estéticas do sentimento que resultaram nas ideias de base croceana e afins.

Por outro lado, essa mesma ideia de autonomia pôde resultar em pressupostos da l'art-pour-l'art, de valorização da legalidade interna da obra, que, mesmo sem se relacionar com um tipo de idealismo onde a obra paira como algo transcendente e acima do mundo dos homens, ao se apegar na obra a partir unicamente do que o texto-obra gera enquanto relações, acaba por assumir uma postura que exclui a obra de suas relações com o mundo fora dela, mantendo, por outro viés, uma ideia de autonomia ainda mais radical.

Por isso identifiquei uma raiz pitagórico-platônica como fundamentação de uma nova metafísica da música já no século XX. Tenho mostrado que, no sentido de combater o idealismo residente nas ideias estéticas que tomam o ideário de autonomia e autotelia da obra musical, é certo que toda uma gama de estudos das ciências sociais ligadas aos estudos culturais e antropológicos pode não só contestar essa compreensão do mundo da obra como algo desconectado do mundo das coisas, como contestar a própria noção de obra de arte como algo diferenciado de outras produções. Mais ainda, surgem tendências ao pensamento que toma a música como um processo cultural 
indiferenciado, localizado a partir da investigação de suas identidades regionaisnacionais, e da análise da recepção dos estilos no bojo das relações culturais ${ }^{52}$. Como apontei anteriormente, essas tendências são úteis para o "equilíbrio da balança" mas podem causar distorções se concebidas a partir de uma disciplina onde a existência da arte como algo de diferenciado é condicional.

Uma vez posta esta medida cautelar, o que mais me interessa é o aprofundamento do exame sobre a própria possibilidade de uma definição da arte, tomando como fundamento determinadas tendências poéticas que vêm se delineando nos últimos anos. É desta forma que pretendo pensar a estética. É desta forma que pretendo uma estética de epistemologia mais alargada, que leve em consideração a possibilidade de que tanto a arte quanto o exame da arte feito pela estética podem também se servir de uma compreensão que traga de volta à música certas tendências abandonadas pelo pensamento crítico ocidental ao longo da história. É justamente essa consciência artística que pretendo examinar, procurando demonstrar quais seriam as possibilidades ainda hoje relevantes no sentido de fornecer bases para o discurso filosófico-musical.

Se na primeira parte meu intento foi examinar especificamente o percurso da estética compreendida enquanto disciplina, de seu advento até a sua autoconsciência enquanto conglomerado de epistemologias, e, ao averiguar as abordagens mais específicas no âmbito da estética musical isso pôde ser realizado a partir do exame de sua relação com certas metafísicas da arte que se desdobraram em outras, procuro agora postular determinadas possibilidades - relativas àquela "alguma prescrição" provocada

\footnotetext{
${ }^{52}$ Em minha dissertação de mestrado (GALON, 2011), procurei estabelecer uma relação dialética entre autonomia e pregnância (definida enquanto pertença da obra ao universo cultural). Na ocasião, a abordagem tratava especificamente do problema do neofolclorismo em música, fenomeno onde esta dialética esteve talvez mais latente na história da música, já que ela pressupõe uma cadeia de distinções: entre a música grafada e a não grafada; entre a oralidade popular e a obra de arte; entre arte e artesanato; e, por conseguinte, entre o campo das manifestações culturais e o campo das manifestações artísticas. Foi neste sentido que busquei, na ocasião, o lançamento de uma teoria de sentido onde a ideia de artisticidade era concebida a partir de 'graus' de pregnância ideológico-cultural em uma obra, legando, grosso modo, uma noção onde 'mais artístico' estivesse ligado à 'mais autônomo'. Para evitar que essa fórmula pudesse resultar em uma nova metafísica da arte onde 'arte' seria uma qualidade conferida às coisas, mantendo a ideia de coisa-elevada devidamente matizada em uma relação com a história e a sociedade, foi examinada a possibilidade de uma autonomia relativa da obra de arte, numa análise que buscou relacionar a estética de Heidegger com parte das investigações de Adorno (especialmente evitando aquelas relacionadas à música). Se na ocasião o binômio autonomia-pregnância pôde se orientar numa definição de arte que não punha em cheque a distinção da obra enquanto produção diferenciada e nem buscava discutir o problema da localização da estética enquanto campo específico da discussão sobre arte, atendo-se a uma proposta conceitual de base em torno de problemas específicos de um determinado campo de produções musicais $^{52}$, é certo que agora, para a proposta desta abordagem, é necessário um aprofundamento de outra natureza, onde a ideia de autonomia e pregnância é apenas uma possibilidade de relação dialética dentro de uma definição de arte mais ampla.
} 
em minhas notas preliminares - de uma definição de arte que possa ser tomada como paradigma para uma nova estética. Para tanto, tendo como discussão de fundo as possibilidades metafóricas de uma visão idealista ou materialista, procurarei examinar algumas linhas de pensamento que poderiam ser guias para estas propostas.

Indo nesta direção, talvez seja possível que se examine a possibilidade de definição de arte que fosse aderente a uma distinção entre a arte e qualquer coisa de produzido, mas que, de algum modo, surgisse como uma recuperação de sentidos ignorados ou abandonados ao longo da história devido à ditadura idealista na arte.

Seria possível pensarmos que isso de perdido pode justamente ser uma certa tendência materialista ${ }^{53}$ que retome, no caso da música, algo relativo às suas possibilidades de se materializar que possam ter sido negligenciadas? Penso que sim.

Desde que, como procurei demonstrar no início desta abordagem, tenhamos em mente em primeiro lugar que determinados aspectos de uma estética musical devem ser tomados por um arcabouço interdisciplinar demandado pelo próprio objeto, sua especificidade e sua materialidade concreta. Assim sendo, qualquer abordagem que busque tomar a música como algo indistinto e que prescinda da noção de obra, pode ser melhor veiculada dentro de um arcabouço disciplinar orientado por outras disciplinas nas ciências humanas.

Não que a estética não possa examinar estas noções. Mas a base apriorística da estética que procuro desenvolver, deve levar em consideração determinadas especificidades que partem de uma coisidade especial do objeto enquanto distinto de outros objetos.

Então, trata-se do exame das possibilidades da organização do pensamento estético, ou seja, a disciplina examina as possibilidades da própria disciplina. No entanto, trata-se de um exame que deve levar em consideração aquilo que esta disciplina tem por objeto: a arte e a música. Para tanto, penso que o caminho seja pensar no limite daquilo que a estética pode ter na aderência de certos pressupostos que, historicamente, foram abandonados. Ditas essas coisas, podemos seguir em frente. Se novas estéticas surgiram no sentido de contrapor o idealismo estético dominante, principalmente no

\footnotetext{
${ }^{53}$ Aqui, como o discutido no prefácio desta terceira parte, tomada não num sentido que a associe de forma automática a questões de cultura e identidade, o que, dentro das possibilidades que estamos assumindo, já pressuporia uma confusão epistemológica que nos poria fora da estética, mas num sentido metafórico que oriente uma escolha.
} 
bojo da filosofia italiana, trata-se agora de apontar como se deu esta contraposição e apontar o que mais poderia ser recuperado.

\title{
8. A Necessidade de uma Definição de Arte: O Mundo da Obra e o Mundo das 'Meras Coisas' e A Recuperação de uma Pregnância Material
}

Se de fato a arte pôde ser refém de inúmeras definições, tomadas como paradigma para a compreensão do que ela é, esses paradigmas refletem especificamente aquilo que historicamente a arte representou e representa para os homens. Umberto Eco, ao examinar o problema da definição da arte em múltiplos autores, procurou identificar como se dá o movimento que consubstancia as definições a partir da imbricação entre as poéticas e as estéticas, concluindo que

\begin{abstract}
(...) torna-se impossível fixar a natureza da arte numa definição teoretica tal como é proposta por muitas estéticas filosóficas, do tipo "a arte é Beleza", "a arte é Forma", "a arte é comunicação" e assim por diante. Estas definições são sempre históricas, ligadas a um universo de valores culturais em relação ao qual a experiência estética subseqüente é fatalmente encarada como "a morte" de tudo quanto tinha sido definido e celebrado. E, portanto, tais definições pertencem à ordem das poéticas e não à das formulações filosóficas. E, atitude filosófica correta será, pelo contrário, uma atitude dialética, para a qual "a lei ideal do universo artístico não pode deixar de se auto-construir infinitamente através das estruturas cognoscitivas e operativas da experiência artística em ato e através de vários níveis de reflexão que, do interior da atualidade da arte, ascendem aos planos da crítica, da historiografia, das poéticas e, finalmente, da reflexão filosófica; aí, esta lei reconhece-se, antes do mais, como ideia de artisticidade, ou modo fundamental da intencionalização propriamente artística da experiência" (ECO, 1972, p.128). - grifo теи.
\end{abstract}

Luigi Pareyson, buscando examinar as tendências gerais que nortearam as definições de arte na história, demonstra que se pode assumir três definições tradicionais para a arte: a arte compreendida enquanto um fazer, um conhecer ou exprimir $^{54}$. Essas três concepções, na história, se combinaram de diversas formas, ora prevalecendo alguma mais do que as outras. Mas, em essência, se mantiveram como as três linhas fundamentais e principais ao longo da história das artes no ocidente. $\mathrm{Na}$ antiguidade permaneceu a $\tau \dot{\varepsilon} \chi v \eta$, "um fazer em que era, explícita ou implicitamente, acentuado o aspecto executivo, fabril, manual". O pensamento antigo, no entanto, não se preocupou em teorizar uma distinção entre o ofício do artesão e do artista, entre a arte, como ela acabou sendo conhecida mais tarde, e o artesanato (Heidegger explorará,

\footnotetext{
${ }^{54}$ Todas as citações e alusões a Pareyson nas próximas páginas deste trabalho são de PAREYSON, 1997, p. 21 a 27.
} 
dentro do arcabouço grego do pensar, essa distinção), mas a compreensão de arte enquanto um fazer prevaleceu e não foi dissipada mesmo na distinção entre arte liberal e arte servil. Já no romantismo, por exemplo, teria sido o aspecto da expressão, resultante da "íntima coerência das figuras artísticas com o sentimento que as anima e suscita" (p. 21). O filósofo aponta que a premissa da arte como expressão se desdobrou e se aprimorou, permanecendo inclusive como base das teorias semânticas ou que concebem a arte como linguagem (p. 22). Em todo o percurso do pensamento ocidental, também a arte foi concebida como conhecimento, como no aspecto específico que já apontei anteriormente; este,

(...) em que o aspecto executivo e exteriorizador é secundário, senão supérfluo, entendendo-a ora como a forma suprema, ora como a forma ínfima do conhecimento, mas, em todo caso, como visão da realidade: ou da realidade sensível na sua plena evidência, ou de uma realidade metafísica superior e mais verdadeira, ou de uma realidade mais íntima, profunda e emblemática (PAREYSON, 1997, p. 22).

Pareyson assume, de fato, que essas "concepções colhem caracteres essenciais da arte, conquanto não sejam isoladas entre si e absolutizadas" (ibidem) e, apesar de demonstrar neste capítulo o modo como esses aspectos podem se tornar evidentes enquanto substância no encadeamento histórico, alternando-se enquanto supremacia ora de um ora de outro sobre os demais, mas nunca se apresentando enquanto única essência do que seria a arte, para aquilo que nos interessa demonstrar, o filósofo conquanto apresente uma definição alternativa a partir de sua teoria da formatividade não abre mão de dois pressupostos que me são especialmente caros: justamente uma ideia basilar que preserva a noção de que existe arte e existem obras de arte, e que o fazer da obra de arte é um fazer específico, especial eu diria (aqui não vai um juízo de valor), com relação a outros fazeres.

E se a arte também foi ao longo da história vista como expressão, e aqui este exprimir recolhe uma concepção de linguagem específica, é notadamente importante a seguinte reflexão:

Certamente, arte é expressão. Mas é necessário não esquecer que há um sentido em que todas as operações humanas são expressivas". Assim sendo, em sendo a arte também expressão, não seria este o seu caráter distintivo, e, mais perigoso ainda seria confundir arte e expressão. Por exemplo, dizer que a arte é 'expressão dos sentimentos' pode ter importância no plano da poética, mas é uma perigosa asserção no plano da estética. Pode existir o programa de uma arte lírica, que consista no exprimir afetos e emoções, o que, no entanto, não esgota a essência da arte (...) (PAREYSON, 1997, p. 23). 
Mesmo em uma outra assertiva, onde se diz que a arte é expressiva enquanto tomada como "linguagem" este termo está sendo usado em seu sentido metafórico, uma vez que "se há artes que, como a poesia, adotam a linguagem como matéria, pode-se perguntar, todavia, qual linguagem, precisamente, é uma estátua ou um edifício" (p.23); a questão, obviamente, poderia se estender à música.

No entanto, este exprimir como linguagem, malgrado não esgote também a essência da arte, me parece um dos caracteres mais permanentes quando se pensa em arte ao longo da história. Mesmo se levarmos em consideração que arte não se resume ao aparato filosófico e epistemológico grego, estendendo-o também à possibilidade de compreender outras expressões, mesmo que funcionais, como arte.

Por paradoxal que possa parecer, ao se conceber arte como linguagem - o que poderíamos dizer que é um dos parâmetros da ilusão idealista - seria possível tomá-la como uma transformação simbólica do mundo, e doravante, expressão humana social, porém diferenciada.

Portanto, a expressão atribuída à arte tem um sentido muito especial, tal como se pode encontrar quando se diz, por exemplo, que a arte é "expressão conseguida", onde a ênfase que contém o caráter específico da arte cai não sobre o substantivo, mas sobre o adjetivo. Neste sentido, a obra de arte é expressiva enquanto é forma, isto é, organismo que vive por conta própria e contém tudo quanto deve conter (...). Expressão, então, é um caráter da arte, mais um tipo específico de expressão: A forma é expressiva enquanto o seu ser é um dizer, e ela não tanto tem quanto, antes é um significado. De modo que se pode concluir que, em arte, o conceito de expressão deriva o seu significado daquele de forma" (PAREYSON, 1997, p.b23).

A interpretação dada por Pareyson da expressão artística pode ser parcialmente relacionada ao modo como o poeta e esteta Ferreira Gullar a compreende, especialmente no que diz respeito ao paradigma fundante da arte - substanciada na existência de obras, compreendido na ideia de que a expressão é linguagem, mas uma linguagem outra:

A explicação de sua existência é uma necessidade exclusivamente do ser humano. Valendo-se de diferentes linguagens, o homem tenta explicar o mundo ou aplacar-lhe a presença enigmática, absurda. De certo modo, a linguagem é uma espécie de tradução do sistema de coisas - sem sentido num sistema com sentido, sistema de sinais. Por isso, diz-se que a linguagem é tautológica, redundante, o que se aplicaria mais apropriadamente talvez aos discursos da linguagem verbal e menos à arte, cujos sinais não possuem significação explicita e, se são também criação humana, têm um modo específico de referir-se ao mundo" (GULLAR, 1999, p.29). 
No caso do conhecer, colocado como uma compreensão da arte como saber, é certo que aqui há uma referência direta à compreensão da arte enquanto linguagem cientifica. Aquela mesma que, no caso da música (e mesmo em outras artes) representou a hegemonia de uma determinada ideia de ciência - o paradigma dominante - que passou a orientar grande parte dos estudos e tendências da música no século XX.

Este caso, já aprofundado na primeira parte deste trabalho, é exemplar do modo como as definições de arte caminham pari passu com a produção das poéticas. É esta implicação que motiva Eco e Pareyson a buscarem essas 'tendências históricas' que estou apresentando.

No entanto, neste ponto desta exposição levanto uma hipótese: teriam as definições da música ao longo da história prescindido da percepção de que as poéticas a que elas se referiam eram apenas aquelas, que por inúmeros motivos, se estabeleciam como canônicas? É provável que sim, e temos um exemplo claro: a mais influente de todas as estéticas da música no século XX, justamente a filosofia da música nova de Adorno, é ao mesmo tempo causa e efeito: ela tratou, assim como demonstrei nas estéticas da música no século XIX, de legitimar, do ponto de vista teórico e filosófico, a reivindicação da escola de Schönberg, se não depreciando, em grande parte relegando ao plano da 'retaguarda' e da alienação as manifestações não ligadas aquilo que Adorno considera a via progressista, ou, em outras palavras, a da via emancipação.

É efeito também na medida em que houve toda uma construção histórico-social em torno do estabelecimento da chamada "Segunda Escola de Viena" como a continuadora daquela linha evolutiva a qual me referi na primeira parte: a construção de uma teleologia de matriz germânica que enxerga um caminho coerente de Bach a Beethoven, depois de reivindicada em vários níveis por Wagner, encontrou sua nova finalidade na formação da ideia de uma 'nova escola de Viena'; essa crença, obviamente, teve seus reflexos nas definições de arte não só circundantes do pensamento adorniano como encontra ecos em diversos níveis até os dias de hoje. Em grande parte penso que é possível relacionar a música do século $\mathrm{XX}$ ao acento dado ao aspecto da arte enquanto um conhecer.

Mas este conhecer é o da culminância de um conhecer-se e um revelar-se. Este revelar-se se dá, justamente, na medida da auto-compreensão de suas operações. Se de fato esta tendência foi e de certa forma tem sido dominante em todas as artes, no caso da música ela se consubstanciou na necessidade de cientifização e demonstração cientifica da operosidade do que está em obra na arte musical. É assim que, de uma arquitetônica 
(estética) a música tende à uma engenharia (estática). Sobre essa tendência na arte geral, ainda Pareyson:

\begin{abstract}
Certamente, depois, há um aspecto cognoscitivo, contemplativo, visivo na arte. Mas é preciso evitar caracterizar a arte com esse aspecto cognoscitivo que, do mesmo modo, pode ser conferido a outras atividades humanas. Para certos artistas, a sua arte é o seu modo de conhecer, de interpretar o mundo e até de fazer ciência (...) Mas isto se inclui no caso geral da arte que, na concreta e indivisível personalidade do artista, ocupa o lugar ou assume as funções de outras atividades do espírito humano, isto é, de ciência, ou de filosofia, ou de religião, ou de moralidade, sem, por isso, deixar de ser arte. Mas a arte não tem, de per si, uma função reveladora ou cognocitiva, e menos ainda se reduz a conhecimento (...) . O fato de se haver acentuado o caráter cognoscitivo e visivo, contemplativo e teorético da arte contribuiu para colocar em segundo plano seu aspecto mais essencial e fundamental que é o executivo e realizador, com grave prejuízo para a teoria e prática da arte. Segundo todo um filão da história do pensamento estético, a partir de um certo platonismo renascentista a Schopenhauer e até Croce, a tarefa da arte é contemplar, (...) e com respeito a esta contemplação, é irrelevante que a imagem interior seja executada ou "repetida" ou "exteriorizada". A arte ignora qualquer fazer que não seja aquele implícito no próprio conhecer (PAREYSON, 1997, p. 24).
\end{abstract}

As múltiplas conotações que essa vertente apresenta, segundo o olhar de Pareyson, demonstra que as imbricações destas três tendências gerais que formulam as definições de arte são titubeantes: pode-se dizer que em cada arte, segundo a sua materialidade, prevalecem determinados derivativos daquelas tendências, e que, se de fato são regidas por ela, o são de modos consubstanciais àquilo que é próprio de cada arte. É como pode ser interpretado, por exemplo, o destino das artes no século XX, principalmente no pós-guerra, quando a exacerbação de um auto-revelar-se (do artista, da obra, do artista na obra) coloca a arte sob o signo do nada. Um nada que, em grande medida, se deve à uma compreensão da arte como algo de indiferenciado. Assim, se ela pode de fato ser linguagem científica ou linguagem cultural, também ocorre a tendência à não-linguagem artística.

Essa tendência, no entanto, atinge a música de forma bastante distinta das outras artes, especialmente se comparadas às tendências mais radicais das artes plásticas. Dino Formaggio, agudo intérprete desses efeitos, e que postula a existência da arte enquanto possibilidade projetual, enquanto lógica do possível, identifica, a partir destas premissas, a tendência a este conhecer, mas assevera a seguinte distinção:

(...) enquanto a matemática e a física teórica colocam ou traduzem a lógica do possível numa organização lingüística do discurso, como discurso científico que tende para a linguagem perfeita e, todavia, para a monovalencia idêntica de seus termos, a arte mobiliza praxisticamente essa lógica em organizações signicas plurivalentes e pluri-significantes, abertas e materialmente 
indemonstráveis, inverificáveis e não discursivas. Aparece aqui uma primeira distinção que pertence ao método das operações em que intervém a lógica do possível, de uma forma diferente da arte e da ciência (FORMAGGIO, 1976, p. 65).

É fácil perceber o quanto a acentuação desta dimensão cientifica e principalmente partidária de uma indistinção das linguagens foi determinante para uma definição que contribuísse especificamente para as poéticas artísticas do século XX e XXI. Por isso a leitura destes filósofos, malgrado pretendam combater o idealismo da estética, não rompem com uma visão onde a arte é um fazer distinto das 'meras coisas'; trata-se então de tomar para si a possibilidade de pensar a diferença não em graus que subsumem juízos de valor, mas a partir do caráter coisal do que cada arte é. E se ela se encontra ainda hoje impregnada da premissa do conhecimento,

\footnotetext{
(...) ela o é no modo próprio e inconfundível que lhe deriva do seu ser arte, de modo que não é que a arte seja, ela própria, conhecimento, ou visão, ou contemplação, porque, antes, ela qualifica de modo especial e característico estas suas eventuais funções. Por exemplo, ela revela, frequentemente, um sentido das coisas e faz com que um particular fale de modo novo e inesperado, ensina uma nova maneira de olhar e ver a realidade; e estes olhares são reveladores sobretudo porque são construtivos, como o olho do pintor, cujo ver já é um pintar e para quem contemplar se prolonga no fazer" (PAREYSON, 1997, p.25).
}

Se de fato uma definição de arte é tão difícil, já que todas as características que se assumem como essência nesta proposições são generalizáveis em algum nível à toda operosidade humana (nos dizeres de Pareyson), devemos nos perguntar: essa tentativa de defini-la é mesmo necessária? E, se eu afirmei que uma proposição que assuma o paradigma de que existem obras e existe arte é necessária para a formulação de uma estética, fazê-la sem que essa proposição assuma o caráter de definição prejudica minha empresa? Neste ponto, Umberto Eco deve ser ouvido:

(...) uma definição geral da arte sabe que tem limites: e são os limites de uma generalização não verificável mas tentadora; os limites de uma definição marcada pela historicidade e, portanto, suscetível de modificação noutro contexto histórico; os limites de uma definição que generaliza, por comodidade de discurso comum, uma série de fenômenos concretos que possuem uma vivacidade de determinações que na definição se perdem necessariamente. No entanto, uma definição geral da arte é indispensável: é gesto que se pratica, um dever que se cumpre para tentar estabelecer um ponto de referência para os discursos que são, pelo contrário, deliberadamente históricos, parciais, limitados, orientados para uma escolha (crítica ou operativa). Mais ainda: a partir do momento em que e fala de arte, ainda que para negar a possibilidade de a definir conceitualmente, não nos podemos furtar à exigência da sua definição (ECO, 1972, 143). - grifo meu 
Claro está que, ao tecer meus próprios comentários com respeito aos problemas levantados por todos esses autores, já venho aos poucos delineando minha própria definição de arte. É claro que ela depende, em larga medida, de uma abordagem mais aprofundada de determinados problemas da arte e da música substanciada nas poéticas da contemporaneidade que ainda pretendo levantar. De qualquer forma, a partir daqui, penso que um caminho pode ser desenhado. Se todos esses autores admitem esse componente distintivo da arte, penso que este pode ser um ponto de partida, podendo ser agregado ao paradigma que assumi de saída: se existe arte e ela se dá em obras, este fazer é um fazer distinto que resulta em algo diferente de uma mera coisa.

\section{Três Estudos de Caso: Coisa e Transcendência na Arte Através das Obras}

A aparentemente simples pergunta "a obra de arte é uma mera coisa?" esconde aquilo que para mim pode ser considerado o cerne do pensar música hoje, e daquilo que seja um caminho para uma definição de arte afim. Este questionamento, longe de figurar como uma pergunta retórica ou meramente especulativa, trás, inadvertidamente, uma série de considerações tomadas como questionamentos apriorísticos: a) o que é arte; b) o que é uma coisa; c) o que é uma obra de arte; d) se é possível arte sem obras.

Como é possível percebermos agora, nenhuma delas é de fácil resposta, e o que parecia simples resulta quase que irredutivelmente complexo. No entanto, em definidas algumas hipóteses para essas perguntas, o complexo poderá resultar simples quando consubstanciado em epistemes, e aqui vai uma síntese deduzida de muito o que se disse até aqui: se a obra de arte puder ser tomada como uma 'mera' coisa, ela poderá ser objeto de exame de qualquer disciplina em qualquer campo que a investigue segundo sua disposição material; se a obra pode ser tomada como algo para além das meras coisas (o que necessariamente não implica numa metafísica) essa coisa específica que a arte é necessitará de uma epistemologia que dê conta desta especificidade, que necessariamente não deverá se ocupar unicamente de seu arcabouço material, enquanto produção.

A partir deste exame, poder-se-á quiçá ser atingido um modo específico para um delineamento epistemológico mais efetivo para a música, correspondente aos problemas e as proposições que realizamos na primeira parte; e, consequentemente, para o pensamento sobre música a partir da estética. 
O que define distintivamente a obra de arte? O que define distintivamente a obra de arte musical?

Se tomarmos como aforismos dois postulados famosos:

"Arte é tudo aquilo a que os homens na história chamaram e chamam arte"

(Dino Formaggio, 1976)

"Uma coisa que realmente não existe é aquilo a que se dá o nome de Arte. Existem

somente artistas"

(Ernest Gombrich, 1950)

Temos que, por um lado, a arte se dá no reconhecimento de sua existência pelos homens, enquanto por outro, a arte é um conceito abstrato condicionado à atividade do artista. Na primeira hipótese, temos a possibilidade de que a arte se dê a partir de um hecho estético, ou de um denominar; a artisticidade não é só consubstancial ao fenômeno obra. Na segunda, ela é condicional ao sujeito que a realiza ou fabrica. Em ambas as expressões a obra é um fenômeno secundário. De certa forma, estas afirmações desvelam pontos essênciais pelos quais o pensamento moderno se concretizou: a centralidade do homem (sujeito) paradoxalmente é a marca do século da anonimato.

Não me oponho a estas definições. Mas compreendo que a desagregação da ideia de obra, que marca simbolicamente o caráter negativo da experiência estética do século XX é menos plural, apesar de incluir possibilidades de compreensão da arte antes desconhecidas. Penso que chegou o tempo de recuperar noções sem que se mutile o já existente. A obra e seu mundo podem fazer sentido em nossa época.

No entanto, mesmo essas noções ainda não estão sob o signo da desagregação. Elas podem, ao menos, serem interpretadas segundo uma ideia de obra de arte, algo que será, paulatinamente, abandonado. Nesse sentido, independente do que a arte possa ser, ela pode ainda se dar como algo de produzido, de formado, seja no seu fazer, seja no reconhecimento de determinado fazer como arte; o que inexoravelmente leva em conta o homem, seja para produzi-la (o artista) seja para nomeá-la ou reconhecê-la ${ }^{55}$.

\footnotetext{
${ }^{55}$ Opto aqui por estabelecer uma relação entre estes dois postulados evitando conscientemente um exame mais preciso sobre questões que envolvam o estabelecimento de um elo entre arte e intencionalidade.
} 
Por que, para uma estética de hoje, ainda seriam importantes essas questões? De modo mais direto, posso responder: penso que a legitimidade da estética enquanto disciplina depende, em maior ou menor medida, da existência de um campo artístico, a partir do qual se produzem obras chamadas artísticas, que demandam uma compreensão e uma veiculação sígnica relativa à história, e que diz respeito àquilo que é próprio do homem. A tomada da estética como disciplina moribunda (assim como a filosofia) não diz respeito apenas ao paradigma dominante da ciência. Diz respeito também à ideia de que a arte morreu. E existem duas formas de morte da arte: a morte do homem - que também se dá pela exacerbação do homem, como veremos - e a ereção da arte ao estatuto de "mera coisa". Neste sentido, é bom que estejamos fundamentados em um processo que possa abarcar algumas distinções. E com respeito à música?

Neste caso, é possível pensar que, de todos os paradigmas aos poucos abandonados pelo desprezo da vanguarda, no que diz respeito à música, a única que parcialmente prevalece é a noção de música enquanto algo de produzido. Ou seja, enquanto obra. Mesmo a noção de 'arte' associada à obra pôde ser contestada, mas a ideia de produção tem prevalecido e ainda mantém certa legitimidade. A questão inicial é, qual seria a diferença entre qualquer obra, e a obra de arte.

Em seu A Origem da Obra de Arte, Heidegger propõe um exame, cuja pregnância idealista aparece na possibilidade de se considerar a autonomia relativa da obra de arte, sua atemporalidade, universalidade e seu status de verdade. Se por um lado muitas leituras têm identificado em Heidegger uma ontologia com tendência à hegemonia, e no fundo talvez toda ontologia possua essa tendência, por outro não se pode negar que, de todos os filósofos, talvez Heidegger tenha sido quem mais penetrou fundo no universo da obra de arte. O prejuízo deste penetrar talvez recaia sobre um determinado senso de que a estética heideggeriana poderia de fato ser a negação do social, e possuísse uma pretensão à a-historicidade. Mas, embora a sua filosofia se mantenha num caminho onde a obra é produtora de mundo ${ }^{56}$ - ao contrário de visões mais atuais das ciências humanas, onde a ênfase recai na cultura-mundo produtora de obras - é certo que ela logra em sua empreitada no sentido de identificar a distinção a

Aquilo produzido intencionalmente como obra de arte, ou percebido (independente da intenção do produtor) intencionalmente como arte ficará à margem do que procurarei examinar. O estudo que proponho tem como finalidade estabelecer distinções que possam gerar delineamentos epistemológicos possívelmente aptos à legitimação da estética musical enquanto disciplina.

56 "A subtração e a ruína do mundo (da obra) não são reversíveis. As obras não são mais o que foram. São elas mesmas, é certo, que se nos deparam, mas são aquelas que já foram (die Gewesenen). A obra pertence enquanto obra ao campo que é aberto por ela própria" (HEIDEGGER, 2005, p.31). 
qual estou buscando, e, lida com a devida atenção, com o problema de distinguir o caráter de obra da obra. Isso me é caro, uma vez que estamos tentando encontrar um meio por onde a especificidade da arte se relacione com a possibilidade da especificidade de uma disciplina.

E, se de fato venho admitindo algo da minha experiência na relação com o pensamento que proponho, isso encontra eco não só no que diz respeito à ideia de que uma definição de arte deve estar ligada à investigação e consubstanciação das poéticas como à ideia de que a experiência artística pode fornecer atributos para o pensar filosoficamente a arte, como pude aventar no início desta abordagem. Pensada nestes termos - numa estética que se situe "(...) no ponto de conjunção de filosofia e experiência" (PAREYSON, 1988, p.19), e que, se compreendermos a obra de arte como a existência de algo diferenciado, ou não comum, veremos que o questionamento da estética é justamente esta reflexão que em parte tenta encontrar a obra "entre as meras coisas" (HEIDEGGER, 2005, p.30 § 2), mas que em sua relação transformadora com elas é que se realiza.

A partir deste ponto, pretendo iniciar um caminho para uma definição de arte pela via da inicial distinção da obra de arte com relação às "meras coisas". Neste caso, é Heidegger quem propõe todo um sistema de realização desta distinção.

De fato eu poderia apenas apresentar as minhas conclusões com respeito ao que o pensamento heideggeriano sobre a obra de arte pode trazer para a definição de arte que eu pretendo, ou apresentar suas consequências finais. Mas opto por um estudo mais aprofundado do processo de distinção que Heidegger realiza justamente na tentativa (humilde, neste caso) de demonstrar, a partir do processo, as possibilidades de levantar questões relevantes para esta proposição.

Não me furtarei a relacionar outros autores para elucidar determinadas questões. Esse processo, ao meu ver, aparece como uma boa alternativa aos ditames formalistas da arte pela arte, mesmo que se mantenha sua visão voltada para obra e não necessariamente para o homem que a produz. Heidegger, como veremos, é um passo importante rumo a uma compreensão que passa a ver o mundo dos homens de uma outra forma. Sem abrir mão da obra. 


\subsection{Heidegger e a retirada da obra ${ }^{57}$ do mundo das coisas}

\subsubsection{O Complexo Matéria-Forma}

A pergunta "onde é que o complexo matéria-forma tem a sua origem, no caráter coisal da coisa ou no caráter de obra da obra de arte?" (HEIDEGGER, 2005 [1935], p.20) é a questão essencial levantada na tentativa da diferenciação entre obra de arte e qualquer outra obra ${ }^{58}$. No modo como Heidegger a compreende, a forma define a ordenação da matéria e ao mesmo tempo define a qualidade e a escolha da matéria, determinados em seu todo por essa interdependência. Esta imbricação entre forma e matéria regula-se de antemão por aquilo para que servem precisamente a coisa - bloco de granito, cântaro, machado, sapatos etc. A serventia, então, seria uma condição da existência da coisa. A serventia é o traço fundamental, a partir do qual o ente reluz e se torna presente. Assim sendo, é fundado um complexo matéria-forma na serventia do ente, e o tipo de forma se dá a partir da escolha da matéria. O ente, neste caso, é sempre o produto de uma fabricação; é fabricado como apetrecho para algo, e "por conseguinte, matéria e forma, enquanto determinações do ente, têm a sua raiz na essência do apetrecho", na sua funcionalidade (ver p. 20-21)

Como conclusão temos que matéria e forma não determinam a coisidade da mera coisa, embora um ser-apetrecho, criado com o destino de sua funcionalidade repouse em si como coisa pura, ele não tem a forma espontânea do bloco de granito. Em outras palavras, a distinção heideggeriana parte do prossuposto de que existiria uma gradação da coisa ao apetrecho, que embora repousem em si mesmos como coisa pura se distinguem pela espontaneidade de algo de construído para uma serventia e algo que repousa numa não-serventia.

No entanto, o que a coisa é, em sua mais pura definição - o bloco de granito, sem função - é a de mais difícil penetração. Ao contrário do apetrecho, uma coisa com uma serventia. Embora o poeta Ferreira Gullar censure determinadas questões da

\footnotetext{
${ }^{57}$ Todas as referências deste estudo são de HEIDEGGER, 2005 [1935]. Para evitar a redundância opto pela referência completa apenas nas citações com recuo, deixando apenas assinaladas o número da página nas referências no início do estudo, no corpo do texto, ou após a referência a outros autores.

${ }^{58}$ Por exemplo, um bloco de granito: algo de material numa forma definida. Forma: ordenação das partes da matéria nos lugares do espaço; contorno definido como projeto no bloco de granito.
} 
filosofia da arte de Martin Heidegger ${ }^{59}$, aqui, aparece uma afinidade, que já adianta determinadas relações: "(...) toda forma (de um bule, de uma planta, de uma pedra) é expressiva por si mesma, mas a sua inserção no universo cotidiano apaga-lhe, por assim dizer, a contundência, embota-lhe o fio." (GULLAR, 1999, p.27). Se, como vimos anteriormente em Pareyson, de fato a expressividade não é peculiar à arte, uma vez que todas as formas podem ser expressivas por si mesmas, por outro lado a sua inserção contextual confere um caráter de distinção ao que seria uma expressividade tomada a partir da arte compreendida enquanto puro formar. Ou seja, já se vê delineado um caminho onde a expressividade de uma forma é mais contundente conforme retirada do universo cotidiano.

\subsubsection{Comparação entre o apetrecho e a obra de arte}

Como próximo passo, temos que Heidegger compara o apetrecho com a obra de arte. Neste sentido, uma primeira convergência natural: ambos são fabricados pela mão do homem, e a obra, surpreendentemente, se assemelha mais à mera coisa pela sua presença auto-suficiente, sem funcionalidade, dando-se em si própria e nada forçada; porém, Heidegger não inclui a obra entre as simples coisas. O apetrecho, surpreendentemente, é meio-coisa, por ser determinado, como vimos, pela coisidade, mas ao mesmo tempo é meio obra de arte, mesmo não tendo a auto-suficiência desta. $\mathrm{O}$ apetrecho tem uma posição intermediária entre a coisa e a obra. Esta é a terceira, e aparentemente mais interessante, das abordagens que Heidegger dá à reflexão sobre o ser das coisas.

Porém, segundo ele mesmo, ainda existe uma importante limitação, que reside no pressuposto "matéria-forma”, cuja mecânica conceitual é brutal, e quase não pode ser contraposta, e que ainda não nos coloca diante da essência do ente-coisa. Por conseguinte, ainda não se atinge o objetivo de, através de uma reflexão sobre o caráter coisal da coisa, se atingir o caráter instrumental do apetrecho (o ser apetrecho), tampouco o ser-obra da obra de arte.

\footnotetext{
59 É interessante como Ferreira Gullar compreende o problema da obra de forma muito similar à abordagem heideggeriana, mesmo que se oponha ao suposto idealismo de uma premissa baseada na tentativa de "fundar do ser". De qualquer forma, os pontos de toque podem ser tão fecundos, que me ocuparei apenas deles.
} 
O autor, após revelar que o conceito matéria-forma é herança de uma concepção tomista da criação, e revelar o paradoxo que pressupõe o desvelamento do ser num universo "estranho" à fé, resvala na obviedade dos complexos que nos legaram as filosofias da idade média e moderna, e que podem nos ter afastado, à revelia, das coisas, em seu ser-coisa-simplesmente. Ou seja, há já uma clara tentativa em se manter longe do idealismo legado por essas filosofias; no entanto, busca-se um caminho por via da obra.

O autor também especula que é duvidoso que se possa chegar ao ser-coisa, despindo o apetrecho de seu caráter instrumental - segundo o autor, "no decurso da história da verdade sobre o ente, as referidas interpretações (as três baseadas no complexo matéria-forma) se combinaram de modo a que passaram a se aplicar igualmente para a coisa, para o apetrecho e para obra" (HEIDEGGER, 2005 [1935], p. 23) redundando ainda de forma mais séria num modo de pensar, segundo o qual pensamos, não só sobre estas três "entidades" mas sobre o ente em geral. "Este modo de pensar, que a muito se tornou corrente antecipa-se a toda experiência imediata do ente" (ibidem).

Em outras palavras, este modo de pensar enquanto conceitos dominantes sobre a coisa, barra o caminho para que se possa meditar sobre o ser das três entidades. Sem dúvida, a máxima "o que há de mais discreto, a coisa, é o que mais obstinadamente escapa ao pensar"(ibidem) é, neste sentido, fundamental.

Esse pensar a essência se revela um caminho por um labirinto, na medida em que é indispensável a tentativa de deixar a coisa repousar no seu ser-coisa simplesmente. Este projeto, embora aparentemente fácil, deixa deslumbrar o mais difícil: ele deve representar o contrário da indiferença que vira as costas ao ente a favor de um conceito de ser que não foi posto à prova. Esta tarefa, em outras palavras, consiste em voltar-nos para o ente, pensá-lo em si mesmo, no seu ser, mas, ao mesmo tempo, deixá-lo repousar em si mesmo, na sua essência. E o autor se pergunta: será que este "manter-se em reserva" que a mera coisa possui faz parte justamente da essência da coisa. Se assim é, não devemos forçar o caminho para o caráter coisal da coisa.

Todo este caminho, como se pôde acompanhar, é uma forma encontrada pelo autor para nos apresentar o seu modo de pensar. Neste sentido, uma determinada vocação da obra de arte, que analisarei mais tarde, aparece. E Heidegger parece nos demonstrar como se faz uma obra de arte na feitura de seu ensaio. Trata-se desta vocação da arte à metalinguística, que trataremos como sendo uma das vocações da arte. 
De qualquer maneira, chegamos ao mesmo lugar quando percebemos que este processo ainda não foi suficiente para superar esta mecânica gradativa que leva da mera-coisa ao apetrecho, e deste à obra de arte, o que seria muito simplificador. Chegase ao mesmo lugar, mas sem dúvidas chegamos mais completos. Neste sentido, esse complexo de formulações pode muito bem ser interpelado de forma sintética a partir, novamente de Gullar:

\footnotetext{
Por isso, a formulação da experiência na arte conteria um grau menor de abstração, que, nas demais linguagens, estaria mais perto das coisas, do mistério delas: não seria uma tentativa de explicação do mundo, mas de assimilação de seu enigma. Transformado em linguagem pictórica, o mundo, mesmo sem ser expiado, perde sua opacidade, sua insuportável estranheza: humaniza-se." (GULLAR, 1999, p. 30)
}

O que mais chama a atenção tem a ver com a possibilidade de aproximação da arte ao que, na gradação proposta por Heidegger, estaria mais distante: da arte à 'mera coisa'.

\subsubsection{Heidegger propõe um modo de investigação}

O apetrecho de fato é mais identificável com o ser humano, já que é fabricação sua (ao contrário do bloco de granito, mera coisa). Assim sendo, reitera-se que o apetrecho se encontra a meio caminho entre coisa e obra; pensando assim, a conclusão: é mais salutar achegarmo-nos ao caráter coisal da coisa e de obra da obra de arte a partir da investigação sobre o caráter instrumental do apetrecho, já que este reside na particular posição intermediária entre a coisa e a obra, tendo o cuidado de "evitar fazer precipitadamente da coisa e da obra variedades do apetrecho" (p. 24).

Heidegger opta pela seguinte 'metodologia' para se fazer a reflexão sobre o caráter instrumental do apetrecho - uma vez que refletir sobre ele deve levar em conta a possibilidade de deixá-lo repousar em si mesmo: abrir mão de qualquer doutrina filosófica existente, em prol de uma pura e "simples" descrição. A estratégia do autor sem dúvida nos espanta, pela sua astúcia no processo do pensamento; ele já dá pistas de onde podemos chegar.

Não é à toa que a escolha do objeto a ser descrito é um sapato. O argumento é o seguinte: toda gente conhece um sapato, portanto não é necessário ter em frente peças autenticas de sapatos para tal descrição. Basta uma representação pictórica. Assim 
sendo, Heidegger escolhe um quadro de Van Gogh. É muito conhecida esta análise de Heidegger dos sapatos na tela de Van $\operatorname{Gogh}^{60}$.

Grosso modo, Heidegger compara um sapato-apetrecho, o modo como ele se dá e o que ele é, aos sapatos na tela de Van Gogh. A descrição de ambos demonstra que, no caso do primeiro temos que "consoante à serventia, se para o trabalho no campo, ou para dançar, assim diferem matéria e forma" (p.25): o ser-apetrecho repousa na sua serventia, mas a serventia não define o caráter instrumental do apetrecho. Antes é neste caráter que a serventia se torna possível. "A solidez" é sua coisalidade; sem ela o apetrecho não tem serventia. Eis onde se funda o caráter instrumental do apetrecho sapato: na solidez. Porém, a partir dos sapatos de Van Gogh, não se experiencia a percepção da sua funcionalidade. O que há, é exposição de mundo. Os sapatos na tela não são 'sólidos', são uma transformação simbólica da realidade, expondo, a partida da obra, o mundo do camponês, suas mazelas, suas alegrias, e, quase inadvertidamente, foi na obra que se nos revelou a também a essência do apetrecho. Algo que não se daria na coisa real. Foi a obra que nos deu esse caráter essencial da instrumentalidade do apetrecho e quiçá do caráter coisal da coisa, e ao mesmo tempo desvelou o serapetrecho e o ser-coisa.

Assim, pode-se concluir que o que a obra desvela reside no essencial das coisas: que as próprias coisas não se dão a nós. Uma vez que o mais fácil é o mais difícil (as coisas se darem em sua inteireza mais essencial à nós), a obra tira o véu de sobre aquilo que não nos é dado, ou daquilo que não podemos ver por que o véu consiste justamente na brutalidade do pensamento óbvio, tão apontado por Heidegger.

Descobrimos o ser-apetrecho do apetrecho. (...) Não através de uma descrição e explicação de um apetrecho (...) realmente presente; não mediante um relatório sobre o processo de fabricação (...); também não mediante a observação da utilização real dada aqui ou ali à apetrechos (...), mas apenas graças ao fato de nos pormos perante o quadro de Van Gogh [a obra de arte]. Foi este que falou. Com a proximidade da obra, estivemos de repente num outro lugar que não aquele em que habitualmente costumamos estar" (HEIDEGGER, 2015 [1935], p.27).

“A obra de arte fez saber o que o apetrecho de calçado na verdade é. Seria a pior das ilusões se quiséssemos pensar que foi a nossa descrição, enquanto atividade subjetiva, que tudo figurou assim, para depois o projetar no quadro. Se aqui alguma coisa é questionável é só esta, de na proximidade da obra experienciarmos demasiado pouco e chegarmos à experiência de um modo por demais grosseiro e imediato. Mas, antes de tudo, a obra não serviu em

\footnotetext{
${ }^{60}$ Temos ainda, sobre a mesma série de sapatos de Van Gogh, análises que adotam pontos de vista muito diferentes, realizadas por Derrida e Shapiro.
} 
absoluto, como à primeira vista poderia parecer, para uma melhor presentificação intuitiva daquilo que é um apetrecho. Antes sucede que só através da obra, e só nela, o ser-apetecho do apetrecho vem expressamente à luz" (ibidem).

As conclusões de Heidegger, que à primeira vista podem parecer sempre metaforizações e idealizações da obra de arte, penso, puderam ser melhor acompanhadas neste estudo. Sua afirmação de que "na obra, se nela acontece uma abertura do ente, no que é e no modo como é, está em obra um acontecer da verdade" (p.27), alude aqui à empresa que Heidegger buscou: se a arte é $\tau \dot{\chi} \chi v \vee$, ela também se dá como $\alpha \lambda \dot{\eta} \theta \varepsilon 1 \alpha$, esse desocultar da verdade na obra, uma verdade não precipitada na necessária verificação, essa verdade da ciência; mas uma verdade dada como permanência, negação do esquecimento.

Neste sentido, a concepção de arte de Heidegger pode nos fornecer um bom painel para compreendermos a relação entre a obra e a coisa; poderíamos dizer que a coisa possui um enigma, que repousa na sua existência pura e sem significado, e que a arte desvela isso que está ocultado, por isso "na obra de arte, põe-se em obra a verdade do ente" (ibidem). A obra de arte, compreendida assim, se aproxima da obra filosófica, e ao mesmo tempo se mantêm perto da essência das coisas. Na arte estaria, então, a capacidade de conferir sentido às coisas.

Devemos afirmar também que essa definição da obra enquanto expressão da verdade do ente não ocorre segundo aquela ideia já muito explorada (e superada) que pressupõe a arte como imitação da natureza. Esta conformidade com o ente não é a expressão da verdade dentro do que nos propomos refletir, dada na representação. A cópia da realidade das coisas não acede a categoria de "desvelar" a verdade do ente, já que o que se dá "não é uma reprodução do ente singular que de cada vez está aí presente"; "mas sim da essência geral das coisas" (p.28).

Neste ponto podemos nos perguntar novamente se faz parte da estética justamente esta reflexão que em parte tenta encontrar a obra entre as meras coisas, e as coisa fabricadas (cf. p.30). Heidegger chega então a outra conclusão: o que importa é que a reflexão sobre o caráter instrumental do apetrecho, o coisal da coisa e o de obra da obra de arte só tenha se chegado a nós quando pensamos o ser do ente. O caminho para essa reflexão, à revelia de toda uma tradição do pensamento estético, não nos levou à obra através do caráter de coisa que a obra tem; antes achegamo-nos à coisa através da obra. 
Se de fato temos aqui já distinto o que é próprio da coisa com o que é próprio da obra de arte, uma vez que "na obra de arte, a verdade do ente pôs-se em obra na obra, é dedutível que, se a funcionalidade embota a matéria no apetrecho, ela também embotaria a possibilidade de percebermos a obra em seu puro-estar-em-si-mesma. Neste sentido é que a obra revelaria não só o caráter material da coisa, da matéria, quanto, estando livre de qualquer funcionalidade, desocultaria o ser das coisas.

Neste ponto, me permito uma digressão que pode ser complementar. Se uma das qualidades (boa ou má, não sei) do estudo de Heidegger é estabelecer uma relação de origem tomando a formulação grega como parâmetro ${ }^{61}$, Formaggio também traz toda a carga de grecidade em sua análise do nascimento da arte na mitologia, identificando certos caracteres partindo da demonstração da passagem de uma concepção de arte para outra no hino de Homero a Hermes (FORMAGGIO, 1976, p.22). Ali, noturnidade, estratagema secreto, clandestinidade e oculto, são caracteres que impregnam uma noção originária de arte. Toda essa pregnância se verá na contribuição à noção de hermetismo, que separará a arte das musas (a música em sua totalidade inextricável) das artes figurativas, cuja emancipação do aspecto mecânico e servil demorará ainda a ser mudado.

Neste sentido, tomando ainda Formaggio, a técnica artística se inscreve nos caracteres da mediação real, criadora e imaginária, como modelação metamórfica do mundo. Hermes consegue isso ligando-se a Eros. Por isso,

\begin{abstract}
O poeta grego (лоıптท่ ) não é ainda um "criador" artístico, mas um construtor e ordenador técnico de uma matéria de origem divina. Ele tem, precisamente, a ver com a técnica. Só com a nova dimensão da consciência judaico-cristã o termo pode ser associado ao ato criador, ao sentido mais profundo do "criar do nada", segundo a típica conotação que a cultura contemporânea, especialmente a romântica, como se sabe, deu ao termo poesia, e reflexamente, ao termo arte (FORMAGGIO, 1976, p.37).
\end{abstract}

A empresa realizada no sentido da superação da pregnância tomista do ens creatum parece ser um objetivo comum dos filósofos da arte na modernidade. Por diversos caminhos, a ideia de 'criação' vem sendo posta a prova; mas ao pô-la à prova, não pressupõe o abandono da ideia de obra, e sim de libertá-la desta condição. De fato,

\footnotetext{
${ }^{61}$ Não um parâmetro geográfico, posto que a Grécia, nesse sentido, é quase indefinível enquanto cultura ou geografia, sendo muitas vezes mais imaginada que real. Neste caso, trata-se da Grécia metafórica, representando o devir de uma consciência racional, de um logos.
} 
trata-se de um primeiro passo para o rompimento com a possibilidade de uma metafísica da arte. Pareyson, como veremos mais tarde contribuirá para uma concepção de obra como invenção.

\title{
9.1.4 O papel do artista
}

\begin{abstract}
Através dele, a obra deve ser libertada para o puro estar-em-si-mesma. Justamente, na grande arte, e só ela está aqui em questão, o artista permanece algo de indiferente em relação à obra, quase como um acesso para o surgimento da obra, acesso que a si próprio se anula na criação (HEIDEGGER, 2005 [1935], p.31).
\end{abstract}

Heidegger especula: para que a obra fosse acessível em si, ela deveria ser "retirada" de tudo que é outro em relação a ela, e se pergunta se esse não é de fato o intento, desde sempre, do artista. O autor se refere a nossa relação com a obra através do caráter objetal destas. Os quadros no museu, a crítica literária e musical, enfim o que nos chega são as obras subtraídas do mundo em que foram criadas. Elas, que foram, estão perante nós no âmbito da tradição e da conservação. O seu mundo original ruiu. No entanto, o seu estar em frente a nós constitui uma consequência inevitável de seu primeiro estar-em-si. É quando o autor se pergunta: não é próprio da obra estar em relações? E responde: sim, mas nos cabe avaliar em que relações ela se encontra. (p.32) Heidegger concebe então a obra como vinculada a um mundo de relações.

Em suma, o autor descreve assim o ser-obra da obra:

- A obra quando se instala é um erigir que consagra e glorifica.

- O ser-obra da obra exige este erigir enquanto consagração.

- A obra requer esta instalação por que ela própria, em seu ser, é instaladora.

- A obra instala, levantando-se em si mesma o mundo que ela abriu numa permanência que o domina (p.34).

O que é o mundo nesse sentido?

O mundo é o sempre inobjetal a que estamos submetidos enquanto os caminhos do nascimento e da morte, da benção e da maldição nos mantiverem lançados no Ser. Onde se jogam as decisões essênciais da nossa história, por nós são tomadas e deixadas, onde não são reconhecidas e onde 
de novo são interrogadas, aí o mundo mundifica (HEIDEGGER, 2005 [1935], p.35).

- A pedra, a planta se inserem no mundo mas são destituídas de mundo.

- A camponesa tem mundo, porque se mantém na abertura do ente.

- O apetrecho confere a este mundo uma necessidade própria.

Ao abrir-se um mundo, todas as coisas adquirem sua demora e pressa, a sua distancia e proximidade, a sua amplidão e estreiteza. A obra instala um mundo. Abre espaço para que todas as relações que um mundo possui venham a ser. Liberta o conjunto de traços que caracterizam o mundo que ela mesma abriu. E mantém aberto este mundo (ibidem).

A instalação de um mundo é o primeiro traço essencial da obra de arte. O autor busca o segundo traço essencial novamente na essência produtora e de produção da obra de arte. Para tanto, volta a ressaltar a matéria que compõe a realidade concreta ou objetal da obra - som, linguagem, pedra, cobre. Na comparação com a coisa e o apetrecho um aspecto surpreendente da obra nos submete: se a coisa (matéria) se esvanece na serventia do apetrecho - ela é tanto melhor quanto menos resistência oferece ao seu esvanecer. Ou seja, no machado a pedra é a matéria determinada pela serventia que terá o apetrecho. Mas ela é consumida na fabricação do instrumento. No caso da obra, quando esta instala um mundo, longe de fazer a matéria que a compõe esvanecer-se, a faz ressair:

(...) a rocha passa a jazer e a estar imóvel e, só então, é rocha; os metais passam a resplandecer; as cores ganham luminosidade; o som adquire a ressonância; a linguagem obtém o seu dizer. Tudo isso ressai na medida em que a obra se retira na massa e no peso da pedra, na dureza e na flexibilidade da madeira, na dureza e no brilho do metal, no esplendor e na obscuridade da cor, na ressonância dos sons e no poder nomeador da palavra (HEIDEGGER, 2005 [1935], p.36).

Se a obra faz 'ressair' a coisidade da matéria em todo o seu esplendor, isso, só ocorre porque a própria matéria, ou seja, a mera coisa ainda sem forma, é quem indica as possibilidades da arte. Neste ponto, Dino Formaggio novamente pode ser complementar: a matéria é co-fundante da arte na medida que ela, a arte, "sempre conheceu as direções operativas da matéria: e sempre compreendeu que não se pode dominá-la sem lhes obedecer" (FORMAGGIO, 1976, p.123). 


\title{
9.1.5 A obra se retira para terra; e produz terra nesse retirar-se
}

Na colocação do segundo traço essencial do ser-obra, a reflexão de Heidegger atinge um nível notável de complexidade, que continua me interessando justamente por aspectos colaterais que apontam para importantes distinções: uma vez que a obra provoca uma abertura para o desvelar do ente - instala um mundo - ela produz terra, uma vez que "traz a terra ao aberto como o que em si se fecha" (HEIDEGGER, 2005 [1935], p.37).

O Autor dá diversos exemplos práticos de que os entes (que compõem a terra) só se mostram quando permanecem ocultos e inexplicados.

\begin{abstract}
A terra faz assim despedaçar em si a tentativa de intromissão nela (...). A terra só aparece abertamente iluminada como ela própria onde é guardada e salvaguardada como a que é essencialmente insondável, que recua perante toda a exploração, a saber, a que se mantém fechada (ibidem).
\end{abstract}

Em outras palavras é possível identificar um combate entre o ocultar-se e o desvelar-se, que se dá em diversos níveis na obra ${ }^{62}$. A coisa perde o seu enigma na medida que é revelada em seu ser coisa. A escultura pode revelar a dureza do mármore a partir da leveza que a forma artística lhe dá. O som pode obter seu verdadeiro brilho a partir do tratamento que recebe em um jogo de relações. É parte da realização da obra ser um puro formar que embota o material não par fazê-lo esvanecer na serventia, como num ser-apetrecho, mas para que ele se mostre não mais como uma coisa, mas como uma coisa onde o significado oculta o signo, justamente para desvelar o que a coisa é.

Assim, finalmente, temos a transformação simbólica do mundo das coisas. Essa é sem dúvida uma opção por uma definição que não só distingue a obra de arte de uma "mera coisa", mas também, colocando-a em uma relação de interdependência com ela, a transforma no sentido de um desvelar que se dá num ocultar.

A fórmula pode ter a aparência de mera retórica idealista. Mas revela um aspecto que unifica aquelas três tendências a que se refere Pareyson: a obra é um desvelar porque exprime a verdade da coisa; é um conhecer que se dá pela mediação de uma

\footnotetext{
62 "A instituição de um mundo e a produção da terra se dão na essência do ser-obra da obra; na unidade do ser-obra se dá o combate entre o "abrir-se" do mundo e o "ocultar-se" da terra. A terra não pode renunciar ao aberto do mundo - é ele quem se funda sobre a terra e a faz ressair no seu ocultar-se; o mundo não nega a terra, antes, funda-se sobre ela, que é algo de decidido" (HEIDEGGER, 2005 [1935], p.39).
} 
técnica para o formar; é um fazer porque é uma produção. No entanto, pode-se deduzir das proposições de Heidegger, que a obra de arte apresenta um componente 'parabólico' na medida em que é uma verdade dita a partir de um artifício.

A verdade compreendida enquanto desocultação de um enigma que parte da coisa para um significado generalizável talvez seja melhor expressa pela própria arte na famosíssima poesia de Fernando Pessoa onde, se o poeta é o fingidor, é apenas porque precisa expressar um real mais real que o real.

Aqui se delineia uma definição de arte que, partindo de uma tentativa em equilibrar suas tendências hegemônicas, se torna substancial enquanto singularidade.

Embora até aqui este conceito, de certa maneira também desgastado pelo uso, não apareceu, é bastante óbvio que o caminho traçado pelo pensamento heideggeriano pressupõe, na sua busca pelo ser obra, uma diferenciação entre a arte e artesanato (serapetrecho ou fazer serial) e o mundo da obra e o mundo das coisas. A obra de arte, por meio de sua singularidade, funda o mundo e desvela a verdade das coisas ${ }^{63}$.

\subsubsection{Pertence à essência da verdade negar-se sob o modo da dupla ocultação}

\footnotetext{
63 Mas o que é a verdade? A partir deste ponto o autor reflete sobre os conceitos "gastos" de verdade. Para tanto, especula sobre esses conceitos, mostrando o quanto são circulares, redundando sempre em becos sem saída. De modo geral esses conceitos partem da verdade compreendida enquanto adequação entre o conhecimento e o seu objeto, pelo menos desde Descartes (p.41-42). O pensamento heideggeriano ganha ainda mais complexidade quando se adentra na questão do modo como se dá esta desocultação:
}

- O ente está no Ser.

- O homem é impotente para dominar uma larga parte do que há no ser.

- O conhecido é algo de aproximado. O dominado algo de incerto.

No entanto, no seio do ente advém algo de aberto:

- O ente só pode ser quando advém no clareado desta abertura.

- Graças a este aberto, esta clareira, o ente é desocultado de algumas formas.

- No entanto, é nesta abertura que se encontra o oculto.

- Portanto é uma estranha oposição da presença o que ocorre na abertura do ente.

- A ocultação que surge é de dupla modalidade: como recusa do conhecimento do ente; como uma ocultação que dissimulação - o ente dissimulado/iludido pelo ente - se assim não fosse, não nos enganaríamos de nada com respeito ao ente.

A essência da verdade, da desocultação é regida por uma recusa: A nós o ente se dá, e mesmo na tranqüilidade (de saber o que são as coisas que nos cerca) existe a intranquilidade de não saber o que são em si mesmas. Penso que o que se desoculta pode ser o "saber que se está ocultado", e isso de estar ocultado pode ser a "verdade das coisas" - por isso só apreendemos a verdade a partir da ocultação, por isso Pareyson diz que as múltiplas interpretações são verdadeiras ou participes da verdade. A apreensão do ser é sempre caudatária de deste combate no abertura do ente - da recusa e da dissimulação; incerteza e da certeza; do clareamento do que esta oculto, inclusive da possibilidade de ver o oculto sem poder desoculta-lo por completo. A verdade que ocorre na obra não tem a ver com a justeza da sua representação; antes tem a ver com a manifestação deste combate, que traz o ente na sua totalidade ao clareado da desocultação (HEIDEGGER, 2005 [1935], p.44). 
Quando Heidegger conclui que, "desta forma, o ser que se oculta clareia-se. O clareado desta natureza na obra é o belo. A beleza é um modo como a verdade enquanto desocultação advém." (p.45), devemos ter em mente que aqui não temos o 'belo' no sentido metafísico. Belo, aqui, ocorre no sentido metafórico, talvez tal como um "(...) deflagrar, no seio da banalidade, o maravilhoso, o poético, o dramático, o inesperado, enfim, esse acontecimento que chamamos de obra de arte" (GULLAR, 1999, p. 19).

Se o que tínhamos antes era um paradigma - existe arte e obras de arte (consequentemente artistas) - e uma pergunta: o que a obra possui de distinto com relação a qualquer obra ou qualquer coisa? Parece que pudemos ver, em parte, qual é o processo de diferenciação entre a arte e o comum, entre a obra singular e qualquer obra.

O próximo e último passo que me interessa nesse estudo tem a ver com o caráter de ser-criado da obra. Heidegger atesta, sobre a obra, que mesmo assim tivemos que passar ao largo de uma outra coisa essencial, que é justamente aquilo que nos é dado de forma mais evidente em sua aparência: o seu caráter de ser-criado; o elemento coisal na obra.

Essa questão é essencial, pois, se busco uma definição de arte que se consubstancie a partir de um cruzamento entre o pensamento contemporâneo sobre arte e as produções de arte contemporânea, não há dúvidas que a compreensão que distingue obra como algo de criado de algo de produzido, é uma das poucas permanências destas elaborações que podem se coadunar com quase todas as possibilidades de investigação.

A partir daqui, Heidegger elabora uma questão: como é que o ser-criado faz parte da obra? Que desemboca em outras duas: o que quer dizer ser-criado e criar? em oposição a ser-fabricado e fabricar? ${ }^{64}$ A necessidade de se diferenciar o caráter de produção da obra a partir da diferenciação entre a criação e a fabricação se dá a partir da conclusão de que "o caráter-de-obra da obra consiste no seu ser-criada (Geschaffensein) pelo artista" (HEIDEGGER, 2005 [1935], p.47-48).

Este ponto é crucial. Podemos ver que, até o momento, a filosofia da origem da obra de arte de Heidegger é um perscrutar do ser da obra. Ela é produtora de um mundo e é uma desvelar. Mas e o homem? E a relação com o mundo histórico e social?

\footnotetext{
${ }^{64}$ Como e em que medida se determina a pertença do ser-criado à obra?

- "Da essência da obra faz parte o acontecimento da obra" (p.45).

- A pertença do ser-criado à obra só será determinado a partir de um esclarecimento ainda mais originário sobre a essência da verdade.

- A pergunta sobre a verdade e sua essência volta de novo.
} 
Aparentemente, a obra é justamente uma retirada dialógica (da projetualidade de um formar por formar) de uma coisa do mundo das meras coisas.

Em outras palavras, a retirada do singular (Formaggio diria "raridade") em meio ao cotidiano. Não é difícil acusar Heidegger de um autonomismo que retira a obra inclusive do homem, como se o mundo que ela funda prescindisse de qualquer relação histórica e social, mesmo de uma relação comquem a produz. Nesse sentido, aparentemente, falta à filosofia de Heidegger o componente material no sentido que antes apresentamos. Mas não podemos esquecer duas questões importantes:

1) Heidegger não se atreve a subsumir em um juízo de valores aquilo que pode ou não ser 'arte', como se o que fosse "artístico" fosse melhor do que o que não é.

2) O fato estético, o desvelar, que ele diz só ser dado nas grandes obras, também não aparece em exemplos de graus hierárquicos. O único pressuposto por assim dizer mais 'rígido' da filosofia heideggeriana é a tomada de posição com relação à extração da origem da obra do universo grego. Neste sentido, a arte se distingue do artesanato, não possui função, é tendente à singularidade. Enfim, esta é uma filosofia da 'obra'. No entanto, Heidegger dá também atenção ao homem.

\footnotetext{
A origem da obra de arte e do artista é a arte. A origem é a proveniência da essência, onde advém o ser de um ente. O que é a arte? Procuramos a sua essência na obra real. A realidade da obra determina-se a partir do que na obra está em obra, a partir do acontecer (Geschehen) da verdade. Pensamos este acontecimento como o travar do combate entre mundo e terra. No movimento congregado deste combate, advém o repouso. Aqui se fundamenta o repousar-em-si (Insichruhen) da obra (HEIDEGGER, 2005 [1935], p.47).
}

Assim sendo, conclui-se que para apreender a origem da obra de arte deve-se levar em conta a atividade do artista (quem cria). De fato a ênfase na atividade do artista e, consequentemente no aspecto da arte como um fazer, é bastante secundária. Da imbricação daquela coleção de tendências demonstradas por Pareyson que foram apresentadas, fica claro que em Heidegger se deriva do exprimir uma ideia de desvelar. E se todas as formas são expressivas, a arte é forma expressiva enquanto desocultação. Não uma meta-verdade, mas a tendência à desocultação da verdade do material. É neste sentido que se pode concluir que:

- A manufatura não produz obras

- As obras pressupõem a manufatura 
- Há que se distinguir o que a manufatura e a obra podem ter em comum e se diferenciar para que uma seja fabricação e outra criação

De fato, vem à tona a ideia de ser-criado, que "quer dizer o ser estabelecido da verdade na forma (die Gestalt)" (p.51), melhor explicado a partir da ideia de que a criação da obra jamais se reduz a uma simples atividade de manufatura: o usar da criação artística não desgasta a terra como um material, antes liberta-a para si própria. (p.51)

Para que essa diferenciação fique clara, é mostrado, mais uma vez, o problema das interpretações correntes, relembrando que a palavra grega $\tau \dot{\varepsilon} \chi v \eta$ denomina tanto o artesanato (manufatura) quanto a arte. É aqui, à luz da própria expressão grega, que Heidegger demonstra a superficialidade do uso desta expressão para as duas conotações: "a palavra $\tau \dot{\varepsilon} \chi v \eta$ quer dizer muito mais um modo do saber. (...) Saber quer dizer: apreender o presente enquanto tal". Deste modo Heidegger aproxima a $\tau \dot{\varepsilon} \chi v \eta$ da $\alpha \lambda \dot{\eta} \theta \varepsilon 1 \alpha$; uma vez que para o pensamento grego a essência do saber repousa na desocultação do ente. (p.47),

\begin{abstract}
A $\tau \dot{\varepsilon} \chi \vee \eta$, enquando experiência grega do saber, é um produzir do ente, na medida em que traz o presente como tal, da ocultação para a desocultação do seu aspecto; $\tau \dot{x} \chi v \eta$ nunca significa a atividade de um fazer (Machen). (...) A designação da arte como $\tau \dot{x} \chi v \eta$ não quer de modo algum dizer que a atividade do artista seja experimentada a partir da manufatura. Pelo contrário, o que na criação da obra de arte tem um aspecto semelhante ao de fabricação de manufatura é de outro gênero. Este fazer é determinado e afinado pela essência da criação, e permanece retido na sua essência (HEIDEGGER, 2005 [1935], p.47-48).
\end{abstract}

Assim sendo, a obra aparece também como "o deixar-emergir num produto", onde "o tornar-se obra da obra é um modo do passar-a-ser e de acontecer da verdade" (p.48). Não só temos na obra um emergir por meio de um produto como também uma aparente dialética interna: se de fato há o risco do uso da expressão 'dialética' para o contexto da hermenêutica de Heidegger vale lembrar que, da mesma forma que o conceito de 'materialismo' não é prerrogativa do marxismo e de outros usos correntes, 'dialética', uma vez que a filosofia heideggeriana busca um sentido de origem, pode remontar a um sentido heraclítico, derivado de uma ideia de conflito entre permanência e efemeridade, sem a necessidade de uma síntese; quem sabe a obra pode ser justamente definida neste 'combate'? Talvez tenha sido justamente essa a dimensão perdida, no que diz respeito à música, e mais ainda em outras artes, após o advento da vanguarda. Sem o 
combate, só o nada, ou a nulificação. Interpretar a obra de arte como o acontecer deste combate, deste conflito pode trazer luz a esses dizeres:

a verdade é não-verdade, na medida em que lhe pertence o domínio de proveniência do ainda-não-(des)-ocultado, no sentido da ocultação. Na desocultação como verdade advém simultaneamente o outro "des" de um duplo negar-se (Verwheren) (HEIDEGGER, 2005 [1935], p.48).

Ora, a epígrafe deste trabalho pode ganhar aqui uma nova conotação - e é característica do grande pensamento humano essa capacidade de ressignificar-se. Quando Borges diz que o hecho estetico é a "iminência de uma revelação que não se produz" poderíamos certamente identificar o fato estético como esse combate entre ocultação e desocultação. Mas a colocação de Borges traz também a possibilidade de se estender o fato estético ao acontecimento que não é obra, ao ocorrer de um encantamento que pode se dar com algo de não produzido.

Um pôr-do-sol pode ser visto como algo de artístico mas, certamente - a não ser se tomado como ens creatum - não é algo de fabricado ou de produzido pelo artista. Assim, vemos aos poucos delineado um caminho para o qual pode-se especificar a complementaridade no binômio materialismo-idealismo. As dimensões se complementam na medida em que são necessários para compreende-los justamente numa dimensão dialética de natureza não sintética e a partir de um hermenêutica; assim, o fato estético, este 'alumbramento' que poderia ser reivindicado apenas como fato artístico, reside também no receptor e não somente nas possibilidades da obra.

E o modo como Heidegger identifica o homem se verifica na identificação da pregnância histórica na obra: "Clareira da abertura e instituição no aberto co-pertencese. São uma e a mesma essência do acontecimento da verdade ${ }^{65}$. Este é, de diversas maneiras, histórico." (p.49); esta essência do acontecimento da verdade na obra, consubstanciado enquanto acontecimento histórico, se dá pelas condições de produção da obra, e, principalmente, através do artista. Com relação a essa dimensão do artista, um dos raros exemplos que podem ser tomados também para um sentido de poética, por exemplo: "outro modo como a verdade passa a ser é através do perguntar do pensar que, enquanto pensar do ser, designa este no seu ser-digno-de-pergunta" (p.49-50).

\footnotetext{
${ }^{65}$ Há ainda uma questão crucial: porque há uma tendência para a obra na verdade? "Porque pertence à essência da verdade instituir-se no ente, para só então se tornar verdade, por isso há na essência da verdade o tender para a obra, como uma possibilidade eminente de a verdade ser ela própria ente no seio dos entes" (HEIDEGGER, 2005 [1935], p.50).
} 
Em Gullar, a quem a experiência artística traz ainda possibilidades de um olhar diferenciado, essa questão aparece conectada ao problema específico da relação obraartista, convergindo com este exame: "é essa a unidade do pensar e do fazer: o artista não sabe a solução senão quando termina a obra - ela é a resposta à indagação que a fez nascer. Se o artista já sabe a resposta, antes de fazer a obra, a obra é desnecessária ${ }^{66}$ (GULLAR, 2006, p. 134).

\subsection{Em Heidegger algumas conclusões}

Conforme pudemos vir acompanhando, o agudo exame de Heidegger se concentra em encontrar a essência da arte e da obra de arte a partir da reconciliação do sentido de $\tau \dot{\varepsilon} \chi \vee \eta$ com o sentido de $\alpha \lambda \dot{\eta} \theta \varepsilon 1 \alpha$. Essa proposta deixa margem para questões especialmente interessantes para o que nos propomos, especialmente quando a especificidade da música está em jogo, como: em que sentido a $\alpha \lambda \dot{\eta} \theta \varepsilon 1 \alpha$ se daria no caso da obra 'puramente' musical? ${ }^{67}$ Aqui, o questionamento tem a ver especificamente com o fato de que, na concepção musical grega - e quero crer que adotar essa abordagem na contemporaneidade traria muitas vantagens - a música inclui o $\lambda$ ójo da palavra. Logo, sequer faria sentido pensar em uma música 'pura' e sim numa abordagem categorial que explora apenas uma das muitas possibilidades de como a música se dá. Aqui se verifica, mais uma vez, que logos não pressupõe comunicação.

É claro que, em Heidegger, se fala a partir da possibilidade da ocorrência da $\alpha \lambda \dot{\eta} \theta \varepsilon 1 \alpha$, em cujo logos é manifestado segundo a própria linguagem específica de cada arte, não vinculado aos sentidos imediatos da comunicação verbal. Entretanto, partindo destas questões, a verdade desocultada do ente teria o seu limite não só a partir do uso do material, mas também na especificidade da linguagem artística. Ou: essa verdade enquanto desvelar jamais se dá na imediaticidade de uma significância bem determinada, mas também é a verdade da coisa material. Neste sentido, Gullar, para quem a arte é a "transformação simbólica do mundo", e para quem o significado oculta o sinal ou signo (o que a coisa é) se levanta apenas uma parte do problema;

\footnotetext{
${ }^{66}$ Gullar sutilmente toca num ponto central para mim. As teorias apriorísticas em arte, especialmente em música podem ser relacionadas à essa asseveração?

${ }^{67}$ Estas questões relativas à música, aqui antecipadas para que se verifique a natureza de sua associação com a filosofia de Heidegger, serão aprofundadas quando for possível termos uma definição de arte.
} 
Deduzo de Heidegger que essa transformação simbólica do mundo se dá através da obra de arte e é uma estrutura dilemática: ao passo que revela o que o sinal é (a coisa), para além do significado (achega-se a verdade do caráter coisal da coisa, o material: na obra, se evidencia o que é o mármore, o que é o cobre), também dá ao significado sua vocação, que é para a singularidade e para uma verdade que é parábola, ou seja, uma vocação para o que é próprio do homem, para não dizer para o universal. Ambos os caminhos são complexos.

No entanto, de qualquer forma, o problema da filosofia de Heidegger no que diz respeito a essas colocações, ainda residiria numa necessidade de incluir com mais veemência o homem, o social, e o histórico. Como vimos, ele dá pistas para isso. Mas no caso da música, onde o elemento da tradução se impõe de forma tão imperativa, talvez a filosofia de Pareyson possa ser complementar. Isso deve ser realizado, claro, tendo em mente um certo limite (e não sou eu quem o colocarei) do que seria próprio da estética ou próprio de outras disciplinas.

É neste sentido que podemos nos perguntar em que medida o caráter histórico pode se materializar no desvelar que se dá na obra, e se é possível aprofundar um exame do papel do artista - que é, evidentemente, histórico e social - em toda esta hermenêutica ontológica da obra de arte. A pregnância de um antigo idealismo pode aos poucos se desatrelar da estética, mesmo que ela seja uma disciplina, por sua própria natureza, com vocação para a obra. Assim sendo, um próximo passo, após a identificação do mundo da obra e do que dela é próprio enquanto expressão de um desvelar, seria identificá-la num mundo de relações - como Heidegger já deixa entrever - que inclua o homem social. Eis um caminho para uma estética outra: encontrar nela a possibilidade do que é outro em relação da obra. Justifico esse caminho no sentido de uma recuperação. A desagregação de diversos sentidos da arte no mundo contemporâneo nos deixa a pergunta inevitável, que a partir de Heidegger procurei por resposta, afinal, "como notar a presença de uma coisa a mais, se qualquer coisa pode ser arte?" (GULLAR, 2006, p. 35).

No prefácio à esta terceira parte, ao propor, na identificação dialética materialismo-idealismo, uma forma de busca da superação das tendências da estética às 
metafísicas da arte, concluí que deveria proceder segundo um sentido de recuperação.

Uma recuperação do que seria esse materialismo a partir da própria natureza da estética e da filosofia. Uma estética que queira abandonar esta pregnância metafísica, de autotelia e alienação com relação ao mundo social, deve repensar a sua epistemologia. Mas como alertei desde o início, uma verdadeira relação interdisciplinar, não pressupõe que os campos se misturem no limite da descaracterização daquilo que se encontra no cerne das possibilidades de relação com seu objeto. É preciso, como vimos, uma compreensão sobre qual é a natureza do objeto e a vocação da disciplina.

Talvez seja o caso de considerarmos a estética como a última disciplina a se propor uma análise da arte e das obras de arte sem que, ao menos no caso da estética musical, estejamos necessariamente no campo das ciências empírico-matemáticas, nem no seio do exame sócio-cultural. Vimos que os dados destas análises servem à estética. Esse é um dos modos por onde pode se dar o aspecto interdisciplinar. A estética, pelo menos dentro de todas as vertentes que vimos estudando, parece ter uma clara vocação para o mundo da obra. As tendências idealistas e espiritualistas, como vimos, desde o século XVIII e com maior ênfase no século XIX, caminharam rumo ao absoluto, rumo à idealização da obra e da legalidade interna da obra.

No caso do pensamento de Heidegger, um dos mais paradigmáticos do século XX, fica clara essa tentativa essencialista de compreensão do mundo da obra como um mundo autônomo. Por outro lado, as análises que partem do campo dos estudos culturais ou sociais, tendem a ver a obra como um evento, como uma possibilidade de manifestação identitária, local e pregnante de contexto. Não que isto não seja de interesse da estética (pode não ter sido, mas creio que agora é urgente). Mas como procurei demonstrar no prefácio, é o caso de delimitar, de forma sutil e aberta, até onde uma proposta filosófica poderia ir antes de se tornar uma outra disciplina, e, conforme uma das acusações presentes em Hugon, parece ser justamente o caso, quando há um processo de absorção da estética nas disciplinas das ciências humanas.

Não podemos neste caso confundir o que em minha proposta tem a ver como o problema da imbricação das disciplinas com a tomada de um mesmo objeto por disciplinas de naturezas diferentes. É claro que a estética deve levar em consideração os dados da sociologia e da antropologia. Mas na medida que são derrubadas as possibilidades da existência da arte e da obra, e ficarmos com o sujeito e sua relação cultural que pressupõe jorros de significados a partir de um saber não-diferenciado, o 
que teríamos, ao meu ver, já não seria uma estética da música e sim uma sociologia, uma história ou uma antropologia da música.

No entanto, me parece claro que há a iminente necessidade de se incluir em uma estética contemporânea o aspecto do homem e da sociedade e da cultura: ou seja, encontrar este componente material afinado com o que a disciplina pode ter de diferencial, de natureza. Ao que parece, no caso da música, este componente material, tomado em sua radicalidade, levou a um paradoxo. Considerou-se o material como a própria materialidade objetal nas relações matemáticas, no texto da obra, o que de fato pode ser tomado como uma forma de análise material. Mas essa radicalização gerou um tipo de materialismo (relativo ao material composicional, ligado ao aspecto artesanal) que no fundo é uma outra forma de idealismo; uma forma de isolar ainda mais a obra de seu contexto de produção. Ou uma análise objetiva do objeto obra.

Neste sentido, de todas as estéticas do século XX, me parece que, a uma tendência em manter todo um ideário de fenomenologia da obra, após o exame de Heidegger, dois autores da estética italiana podem aparecer para uma contra-proposta, como uma crítica ao totalitarismo idealista, mas ao mesmo tempo se manter nesses limites tênues que fazem com que a disciplina estética se mantenha perto de seus próprio limites. Dos grandes sistemas teóricos pós-heideggerianos, considero que a Teoria della Formatività de Pareyson é um primeiro passo de uma estética que inclui o elemento social, mas ainda sim se mantendo numa hermenêutica da arte enquanto campo específico. Umberto Eco demonstra que, apesar de Pareyson se manter num "diálogo vivo com os temas da estética idealista italiana" (ECO, 1972, p. 14), ele apresenta sua estética da formatividade como alternativa. "No panorama desta concepção estética ampla e desprovincianizada surge a teoria da formatividade de Pareyson que, à concepção idealista da arte como visão, opõe um conceito de arte como forma (...)" (ibidem, p.14). Mais ainda, e para aquilo que mais me interessa, pode-se encontrar nela tanto uma elaboração teórica relativa ao formar, quanto relações entre o problema específico da formatividade como permanente em um mundo de relações.

Assim, aquele que se volta para esta estética para nela encontrar a descrição dos processos de formação e a interpretação das formas no âmbito da intersubjetividade humana, encontra-se (por assim dizer) livre do compromisso metafísico, que o autor assume pessoalmente a um nível ulterior da sua investigação; e este facto explica a influência exercida pela estética Pareyson, inclusivamente naqueles que apenas estavam interessados numa teoria das formas vistas como produtos de cultura. Quer dizer: esta estética que, nos seus limites, põe por conta própria o problema da 
fundamentação "natural" de uma experiência "cultural", funciona também como guia para quem quiser mover-se simplesmente ao nível das relações culturais (ECO, 1972, p. 27).

Outro importante filósofo a lidar com a arte na tentativa de se opor à concepções idealistas, Dino Formaggio pôde configurar uma estética materialista, via marxismo. A partir da pregnância do materialismo histórico Formaggio elabora uma estética cuja principal pretensão é se manter em estreita conexão com os signos da modernidade. É desta forma que ele resgata na história das artes o sentido do nada e da nulificação, e difere de Pareyson especialmente no sentido de não postular uma teoria de aplicabilidade mais geral, mantendo-se no âmbito de uma interpretação e de um sentido para o mundo moderno. No entanto, sua fenomenologia identifica elementos que podem contribuir para minha busca: o sentido de recuperação um elemento da arte e um sentido para a técnica. Se de fato tomo 'materialismo' num sentido metafórico, penso que não seria uma interpretação forçada extrair da contribuição de Formaggio a recuperação do material na estética que possa contribuir para a minha própria definição de arte.

Assim sendo, minha tentativa de definição de arte seguirá, a partir daqui, tendo como pano de fundo as questões filosóficas ligadas aos diversos elementos apresentados no estudo de Heidegger. Mas para completar esta definição, realizarei mais dois estudos num sentido de conseguir uma gradual aproximação a uma a definição que torne possível uma afinidade com a possibilidade de uma estética materialista. Para tanto, devo levar em conta: de Heidegger, as relações mais profundas relativas à exposição de mundo dada na obra de arte, onde a obra e o mundo da obra estão em primeiro plano. Mesmo que o conceito de $\alpha \lambda \dot{\eta} \theta \varepsilon 1 \alpha$ no sentido heideggeriano seja indissociável de uma relação com o homem, a história e o mundo da vida, permanecem como o mundo relacional da obra de arte.

Para seguir nestes estudos, aprofundarei elementos já apresentados na estética de Luigi Pareyson, levantando outros que considero necessários para extrair elementos para uma definição de arte, afinal, Pareyson certamente representa uma maior aproximação a este elemento material, embora também atribua distinções entre um 'formar' que é da arte e um que "está em toda operosidade humana".

Por fim, penso que em Dino Formaggio eu possa encontrar algum elemento para incluir este aspecto 'material' que seja complementar a uma definição de arte. 
Vimos na primeira parte deste trabalho como uma reformulação epistemológica pode direcionar a estética à um patamar que não a coloque, como ocorreu em suas origens e restou pregnante em seus desenvolvimentos ulteriores, como uma mera legitimadora de cânones. Para tanto, os componentes disciplinares e o modo como eles podem se imbricar foram examinados no sentido de encontrar caminhos e hipóteses. Umberto Eco deu pistas para que a sobrevivência da estética não se dê exclusivamente na sua diluição nas ciências humanas, e, para mim, no caso da estética musical, o mesmo se aplica com relação especialmente às ciências empírico-matemáticas.

Com esta pequena recapitulação pretendo nos situar no ponto em que nos encontramos: se temos possibilidades de delineamento epistemológico que possam guiar o processo de renovação disciplinar, é certo que a disciplina deve ter a sua natureza peculiar baseada naquilo que deve ser o seu objeto e sua natureza. Então, se tomamos alguns paradigmas que consideramos importantes para que a estética mantenha o seu núcleo afinado ao seus objetos, uma definição de arte para aos dias de hoje se faz necessária. E é este o caminho que estamos traçando. Às iniciais propostas, podemos ainda somar as preocupações de Gullar:

\begin{abstract}
Se é certo que, em última instância, todo produto cultural é ideológico, não é menos certo que a sua elaboração se faz com certa autonomia, quando se ignora esse fato, ignora-se o que a arte possui de específico; e caímos nas generalizações sociológicas. (...) No pólo oposto, situam-se aqueles que descartam a discussão do caráter nacional da arte como um falso problema. Essa atitude, que visa defender a natureza específica da arte, reflete, a meu juízo, uma compreensão idealizada da criação estética e resulta, quase sempre, na defesa de determinada tendência artística - a da arte pura - com exclusão das demais (GULLAR, p. 82, 2006).
\end{abstract}

Sigo, pois, nesta construção de uma definição extraída do caminho Heidegger Pareyson - Formaggio.

\title{
9.2 Pareyson e a formatividade
}

Se Heidegger nos lega uma ideia primordial de arte definida a partir da recuperação da noção de $\alpha \lambda \dot{\eta} \theta \varepsilon 1 \alpha$, é certo que Pareyson impregna a abordagem a partir da obra e de seu mundo com os sentidos expressivos históricos que se dão na sua 
formatividade, apresentados numa de teoria realizada enquanto filosofia revelativa. Assim, traça um caminho de distinção ainda mais claro entre aquilo que é próprio da obra e aquilo que é próprio do mundo social do homem. Se compararmos ainda a filosofia geral de Pareyson com a sua teoria estética, é possível compreender esse passo em direção ao "mundo da vida", mas ainda mantendo-se fiel a uma compreensão de estética que se dá a partir da experiência de um "puro formar".

Podemos pensar a questão da 'experiência' em Pareyson como estando no arcabouço da obra musical, compreendida como "organismo, que goza de vida própria e tem sua própria legalidade intrínseca" (inspirado na eigene Gesetzlichtkeit hegeliana) cuja substância resulta numa "totalidade irrepetível em sua singularidade, independente em sua autonomia, exemplar em seu valor, fechada e aberta ao mesmo tempo (...)" (PAREYSON, 1988, p.9). A teoria prevê que isso se dá graças à sua autonomia, que por ser relativa e não absoluta, ao mesmo tempo se contextualiza incontornavelmente num determinado Zeitgeist. Em Pareyson, na história fundada pela obra de arte se dá aquela mesma relação heideggeriana do 'combate'. No entanto, este aspecto é mais claro em sua teoria.

O filósofo promove, em sua filosofia geral, a distinção que pretende compreender a natureza distintiva e complementar entre uma filosofia revelativa e outra expressiva, como expus brevemente em momento anterior. Compreender essa distinção, que investiga seria a natureza da filosofia, me parece essencial para complementar uma compreensão da natureza da estética, apontando caminhos ainda para uma definição de arte.

Segundo Pareyson, uma abordagem filosófica revelativa deve levar em conta a possibilidade de um desvelar multíplice e plural dos aspectos que se queiram elucidar através do pensamento filosófico; as filosofias revelativas, segundo o autor, são justamente aquelas que devem ser avaliadas segundo uma perspectiva também revelativa ou especulativa, pois

ascendem ao nível de suscitar uma discussão especulativa, mesmo possuindo um lado expressivo que inevitavelmente acompanha a sua dimensão revelativa. Este pensamento manifesta a verdade. O ser faz-se perspectiva viva sobre a verdade. Revelação pessoal do verdadeiro (PAREYSON, 2005, p.7).

Neste caso, grosso modo, a dimensão expressiva ou historicista serviria mais àqueles pensamentos filosóficos de cunho especificamente historicista, uma vez que 
“(...) nega à filosofia aquele valor de verdade ao qual ela parece ambicionar pela própria natureza de seu pensamento, e não lhe reconhece outro valor do que ser expressão do próprio tempo" (ibidem). Pensadas desta forma (na possibilidade revelativa), as estéticas ou filosofias se autonomizariam com relação às outras disciplinas, principalmente no que diz respeito ao que elas almejam. E como buscam reconhecer-se nesta pluralidade através da ação interpretativa (as múltiplas interpretações são concebidas como co-partícipes da verdade), são capazes de transcender, relativamente, sua pregnância histórica.

De modo algum a autonomia do pensamento revelativo é supra-histórico; antes, ocorre apenas na história e a partir da história. Mas a interpretação de seus conteúdos é parte da própria essência do pensamento, cuja dinâmica interna exige interpretações.

É dentro deste espírito que o elemento individual, do artista, do produtor, pode ser deduzido: mesmo admitindo que se está em pleno exercício hermenêutico de interpretação. Por isso na filosofia, segundo sua própria natureza, deve-se lançar mão de uma abordagem multidisciplinar, onde são consideradas legítimas todas as contribuições das ciências (antropologia cultural, lingüística, história da cultura, psicologia, etc.), desde que elas permaneçam "nos seus limites, dentro dos quais são, efetivamente, insubstituíveis, cumprindo uma função importante, utilíssima para a própria filosofia" (PAREYSON, 2005, p.33).

Também há uma distinção conceitual que Pareyson realiza entre estética e poética, também já demonstrada anteriormente. Esta distinção é utilíssima para que se defina o caráter da presente abordagem - estética - em contraponto com as próprias obras - poética - e como se substanciam as relações entre os conceitos poéticos ou estéticos e as obras (cf. PAREYSON, 1993 e 2001). Esta distinção também é importante para que se compreendam alguns aspectos fundamentais das manifestações sobre arte no sentido de irmos delineando uma definição. Principalmente porque ela é, também como em Heidegger, uma tentativa de recuperação conceitual. Vimos como, no nascimento da estética como disciplina e nos seus posteriores desdobramentos, a falta de clareza para esta distinção resultou numa estética legitimadora e prescritiva, obscura e com vícios conceituais.

Se vimos que em Heidegger, na obra de arte é o pôr-se-em-obra da verdade" (HEIDEGGER, 2005, p.30), podemos ter uma panorama mais completo considerando que a obra se dá como este fenômeno revelativo, e, enquanto tal, “(...) o aspecto revelativo não pode passar sem o expressivo e histórico, porque da verdade não se dá 
manifestação objetiva, mas trata-se sempre de colhê-la dentro de uma perspectiva histórica, isto é, de uma interpretação pessoal" (PAREYSON, 2005, p.12). Temos então este aspecto dado de forma mais enfática: a impossibilidade de uma a-historicidade não só da obra como da filosofia. Por isso, a própria filosofia/estética estaria incontornavelmente em relação com as formas culturais e os estudos investigativos dessas formas.

\begin{abstract}
A investigação das formas culturais humanas, tal como se pratica neste gênero de estudos, conduz certamente a uma intensificação da experiência que o homem faz de si mesmo e do mundo, a ponto de se poder dizer que a filosofia hoje só pode beneficiar-se dos resultados destas ciências; as quais, além disso, são utilíssimas à filosofia também no sentido de que incrementam a pluralidade daqueles campos de experiência nos quais se deve exercitar o pensamento filosófico, em contato com as questões concretas e às voltas com os problemas particulares (PAREYSON, 2005 [1971], p.33).
\end{abstract}

Segundo Pareyson, esse mundo de relações influenciam de maneira determinante o fenômeno da formatividade ${ }^{68}$, uma vez que

\begin{abstract}
há uma correspondência entre certos modos de formar e certos modos de pensar, viver, sentir, e tal correspondência se pode constatar a posteriori, não só com respeito a um artista individual, mas a inteiros períodos históricos: toda civilização tem seu estilo, todo artista tem seu modo de formar. Mas esta correspondência não deve induzir a se pensar em uma "dependência" ou "derivação", e muito menos em uma resultante automática ou mecânica, como se algumas formas de espiritualidade gerassem por si mesmas certos estilos, e o valor desses estilos consistisse no corresponder àquelas formas de espiritualidade (PAREYSON, 1993 [1988], p.31).
\end{abstract}

O aspecto 'da vida', em Pareyson, aparece no modo como a pessoalidade se dá na obra de arte. É nesse sentido que a estética pareysoniana, em seu vivo diálogo com o idealismo como visão, se afasta dele ao, já como um passo adiante, dar ao artista um papel ainda mais efetivo. E isso ocorre quando o artista

\begin{abstract}
se refere à arte como atividade formativa, isto é, inventiva, original, criadora e consiste numa presença, ao mesmo tempo tríplice e única, da pessoa na arte: como energia formante, como modo de formar, como obra formada. Colocada sob o signo da arte, a pessoa se torna vontade e iniciativa de arte, assume inteiramente uma direção artística, traz, de per si, uma vocação formal, torna-se uma carga de energia formante (PAREYSON, 1997, p.107[itálico do autor]).
\end{abstract}

\footnotetext{
${ }^{68}$ Num estudo da Teoria da Formatividade, Sara Cecília Cesca (2015) agrupa, em um esquema geral, as relações entre o processo de invenção e produção da obra, a obra enquanto forma e a execução e leitura da obra (CESCA, 2015, p.28-32).
} 
A questão em Pareyson que nos interessa especificamente, tem a ver com o modo como a pessoalidade se dá na obra, mas se consubstancia numa relação onde a obra aparece como um fazer específico, diferenciado. Se a formatividade se dá em toda a operosidade humana, na obra, ela se dá enquanto uma produção em especial. Eco define de forma mais específica:

\begin{abstract}
Dada pois, a presença conjunta de actividades na pessoa que age inteiramente, o que distingue a arte das outras iniciativas pessoais é o facto de naquela todas as actividades da pessoa terem uma intenção puramente formativa: "Na arte, esta formatividade, que investe toda a vida espiritual, e torna possível todas as outras actividades específicas, especifica-se por sua vez, acentua-se numa preponderância que faz depender de si todas as outras actividades, apresenta uma tendência autônoma... $\mathrm{Na}$ arte, a pessoa forma simplesmente por formar, e pensa e age para formar e poder formar" (ECO, 1972, p.16, aspas do autor).
\end{abstract}

Em se tratando desta operosidade dada no processo formativo, no caso das produções do cotidiano (utensílios e artefatos), esse tal fazer que se inventa fazendo se constitui como trabalho, porém intencionalmente realizado para o cumprimento de uma determinada função, cujo resultado deve ser sabido de antemão. Para Ferreira Gullar, para quem a experiencia artística precede qualquer pensamento estético em forma de doutrina, "é essa unidade do pensar e do fazer: o artista não sabe a solução senão quando termina a obra - ela é a resposta à indagação que a fez nascer. Se o artista já sabe a resposta, antes de fazer a obra, a obra é desnecessária. (GULLAR, 2006, p. 134)

Neste caso, a ideia heideggeriana do desvanecer da coisa na função, do signo que se dá na opacidade cotidiana, aparece, mas em formulações mais elucidativas. No caso do fazer específico da arte, e aqui a mesma distinção de Heidegger se perfaz, a obra é "puro êxito": "a arte propriamente dita é a especificação da formatividade, exercida, não mais tendo em vista outros fins, mas por si mesma" (PAREYSON, 1997 p.32-33). Nas palavras de Gullar:

Esse exercício encontra sentido em suas próprias dificuldades, nos obstáculos que se interpõem à necessidade do artista de deflagrar, no seio da banalidade, o maravilhoso, o poético, o dramático, o inesperado, enfim, esse acontecimento que chamamos de obra de arte. O artista não é um produtor de objetos (...). O que lhe interessa é a qualidade e não a quantidade. Cada obra de arte é um ser diferenciado (...) (GULLAR, 1999, p. 19)

Essa diferença, em Pareyson, pode assim ser sintetizada: 


\subsubsection{A regra individual da obra é a única lei da arte}

(PAREYSON, 1993, p.67)

\begin{tabular}{|l|l|}
\hline Na Arte: & Demais operações: \\
\hline "Fazer com arte". & "Fazer com arte". \\
\hline Formatividade. & $\begin{array}{l}\text { Formatividade. } \\
\text { O resultado dita o próprio critério. } \\
\text { antemão, conforme certas leis e } \\
\text { certos fins. }\end{array}$ \\
\hline $\begin{array}{l}\text { A obra satisfaz uma legalidade e a } \\
\text { uma finalidade instaurada por ela } \\
\text { mesma. }\end{array}$ & $\begin{array}{l}\text { Nas outras operações a obra satisfaz } \\
\text { ama legalidade a uma finalidade } \\
\text { imposta pela atividade que nela se } \\
\text { concretiza. }\end{array}$ \\
\hline $\begin{array}{l}\text { Na arte, o modo como se deve fazer } \\
\text { a obra é apenas o único modo em } \\
\text { que ela mesma, que tem que ser } \\
\text { inventada e ao mesmo tempo feita, } \\
\text { se deixe fazer. }\end{array}$ & $\begin{array}{l}\text { Nas outras operações, o único modo } \\
\text { em que abra se deixa fazer é } \\
\text { precisamente aquele em que, } \\
\text { conforme as leis da atividade } \\
\text { exercida, se deve fazê-la. }\end{array}$ \\
\hline
\end{tabular}

Pareyson se afasta ainda mais de uma concepção de obra impregnada com a ideia de ens creatum. Esse formar que é puro êxito se corresponde com um pensar em modo revelativo, que, sem desprezar o expressivo-histórico, se dá no ato da 'invenção'. Inventar é o modo próprio do homem no fazer da arte. A obra não é criação. A obra é invenção.

\subsection{Em Dino Formaggio a reintrodução do corpo}

Vimos que, se a filosofia de Heidegger é um aprofundamento no mundo da obra de arte enquanto manifestação do ser, distinguindo a obra de arte de qualquer coisa de criado e da mera coisa, não pondo foco específico no problema da historicidade e socialidade da relação obra-mundo da vida, a de Luigi Pareyson se aprofunda na compreensão do caráter formativo da obra, dado num processo de invenção. Enfim, ele apresenta uma definição de arte enquanto formatividade. Nessa definição se delineia uma dialética entre um aspecto expressivo e outro revelativo que, de certa forma, 
aproxima o pensamento filosófico e a arte (algo presente em Heidegger também), deslocando levemente o eixo da obra em direção ao 'mundo social'. Neste caminho que venho traçando, é bom que se rememore, a busca é por uma definição de arte possívelmente consubstancial à proposta de uma nova estática.

Esta definição, que parte da premissa de que existe arte e existem obras de arte e artistas, vem se perfazendo a partir da possibilidade de compreender em que medida o mundo da obra de arte se diferencia do mundo das coisas; e em que medida a produção da arte enquanto uma produção diferenciada pode ser examinada a partir do pensamento estético. Para tanto, procurei traçar um caminho que se bifurca em duas possibilidades: por um lado construir o sentido desta distinção; por outro, demonstrar como, em sendo a vocação da estética o mundo da obra, é possível trazer uma contribuição - a partir desta mesma vocação - do mundo da vida, outra forma de aludir àquele materialismo metafórico.

Há então, uma tentativa de encontrar esse elemento a partir de um caminho baseado no pensamento de três sistemas filosóficos modernos. Para completar este intento, identifico em Dino Formaggio um sistema que pode apontar caminhos; quem sabe alternativas no sentido da recuperação de uma materialismo no seio mesmo do pensamento estético, e afinado ao delineamento epistemológico que procurei pensar. $\mathrm{E}$ no sentido de Formaggio, isso se dá a partir da inserção do corpo. Quase posso dizer que se trata de uma estética do pensar a arte e o mundo da arte e da obra a partir do corpo.

Formaggio é caso exemplar da possibilidade de uma estética materialista, tomando aqui materialismo no sentido marxista. $\mathrm{O}$ fundamento de seu pensamento sobre a arte pode ser lido como uma tentativa de libertação da estética da pregnância das antigas e muito conhecidas concepções de arte que, a partir das elaborações gregas, procuram separar o labor, o trabalho das mãos, da atividade intelectual e especulativa, colocando as primeiras em um grau de inferioridade com relação às segundas. Neste sentido, posso afirmar que, no que diz respeito à estética musical, esse é um fator que pode apontar bons caminhos para complementar uma definição de arte, mesmo que o próprio Formaggio não procurasse fazê-lo.

O problema desta divisão, segundo Formaggio, pode ser assim sintetizado:

É necessário reconhecer nesta separação uma figura transitória e ainda inadequada, ligada às situações históricas, de uma consciência que pensa de uma forma alienada quer o trabalho, quer a arte. "A acção humana objectiva 
que transforma a natureza e nela inscreve significados, é um processo único, executado por necessidade e sob pressão de uma finalidade exterior, mas que a mesmo tempo realiza os pressupostos da liberdade e da criação livre. A separação deste processo único em duas esferas, aparentemente independentes uma da outra, não provém da 'natureza das coisas', mas é um produto historicamente transitório; enquanto a consciência estiver prisioneira desta separação, isto é, enquanto não lhe descobrir o carácter histórico, ela opõe o trabalho e a liberdade, a actividade objectiva e a imaginação, técnica e a poesia, como dois modos independentes de satisfazer as aspirações humanas" (Kosik) (FORMAGGIO, 1976, p.113).

Formaggio condena a separação que opõe, na arte, trabalho e ideia. Pensando sempre neste sentido, o filósofo reconhece que a técnica artística não deve ser mais reconhecida como algo exterior à obra de arte, com caracteres de mediação (aqui ele se associa deliberadamente à filosofia de Heidegger). A técnica não é simples meio, ela é o pôr-se em obra da obra. Aqui, vemos delineado um caminho que nos interessa: vimos anteriormente como Heidegger 'coloca' a obra em uma relação com a mera coisa, distinguindo-a desta. Em Pareyson, um caminho que envolve mais claramente o mundo social (o estilo é o homem na obra), mas se atém ao puro êxito de uma formar por formar. De Formaggio podemos extrair a noção de que este fazer, este construir do homem não é um fazer alienante, pois o trabalho e a técnica não são meros meios para o devir da obra, são parte do próprio fenômeno da arte. Ou seja, há um outro viés para se pensar a obra que não seja via sua autonomia com relação ao trabalho.

No antigo discurso idealista ou metafísico, a técnica artística, em vez de se apresentar como ponte de livre reconhecimento entre o trabalho e a arte, entre as esferas de objectivação de pseudo-práxis ou de anti-práxis repetitiva e mecânica e as esferas das objectivações significativas, era relegada para meio subsidiário, não substancial e não necessário, completamente distinto da arte e a ela exterior (FORMAGGIO, 1976, p.120).

O trabalho é, então, o próprio mundo da obra, e a técnica artística é o fenômeno de objetivação do homem na matéria. A estética de Formaggio pode contribui ao intento deste trabalho justamente porque busca recuperar sentidos ofuscados da arte e do trabalho na arte.

Com efeito, a arte pertence à estrutura como tipo de trabalho, isto é, no que se refere à sua práxis de objectivação, enquanto trabalho desalienante; efectivamente, enquanto o homem se objectiva na obra, faz-se a si mesmo, faz-se mais profundamente homem e humanidade (FORMAGGIO, 1976, p.74). 
E Gullar, novamente, pode traduzir bem esta atividade conforme com sua própria experiência artística:

O trabalho artístico, a criação da obra, é na verdade um modo através do qual o artista se constrói fora de si, dá permanência e objetividade à sua fantasia. A objetividade torna-a social, doação aos demais, acréscimo ao universo da cultura (GULLAR, 1999, p. 19) ${ }^{69}$.

Essa objetivação do homem na matéria é, como também o é em Pareyson, um fazer aplicado a todos os âmbitos das operações humanas. Ela está na ação que visa uma produção. Para Formaggio, essa ação também é diferencial no caso da obra de arte; o que ele chama de 'possibilidade projetual' tem a ver com o mundo de possibilidades em jogo no ato de fazer, ou seja, um fazer que não sabe a resposta de antemão. No entanto, a possibilidade projetual artística tem um significado; ela "(...) significa inventar, isto é, encontrar a ponte de inserção eficaz na trama das expectativas individuais e colectivas, das exigências e necessidades, do devir temporal (FORMAGGIO, 1976, p.71). Aqui se delineia mais claramente o intento de retirar a obra de um bojo metafísico; este devir temporal, sugerido em Heidegger e assumido em Pareyson, aparece como um atestado da historicidade da obra. Mas dizer que a obra de arte é temporal e histórica, mesmo em Formaggio, não quer dizer uma negação de seu caráter vocacionado à permanencia e singularidade. Apenas o modus operandi evita a intromissão de um espiritualismo que possa banir a possibilidade de conexão entre a obra e o mundo social. Não há obra fora do mundo. Não há obra fora do fluxo temporal. Apenas em outra parte, em outro "onde" do fluxo. A obra antecipa este fluxo. Há casos "em que a projectação artística configura uma realidade ainda por chegar, se insere no processo do tempo, o sente fluir e o vive enquanto avança, até se tornar antecipadora da realidade ainda por aparecer, ainda a caminho, mas inexoravelmente destinada a efectivar-se por meio de cadeias projectuais internas à história" (FORMAGGIO, 1976, p. 90).

Mas de que forma a obra de arte tem a vocação para permanência? Se de fato a "projetualidade projecta uma possibilidade real no real, religando-a em séries contiguas de tempos fluidos, com estrito contacto entre si, de modo a eliminar certas asperezas das separações entre presente e passado e presente e futuro" (ibidem, p.91), é certo que o golpe que fere o real, desferido por essa imaginação projetual, ocorre a partir do corpo.

O corpo, e só ele, garante a transformação simbólica do mundo. A inserção da

\footnotetext{
${ }^{69}$ No poema O Duplo: "Foi-se formando / a meu lado / um outro / que é mais Gullar do que eu (...) mas sem o peso / do corpo / que sou eu / culpado e pouco" (GULLAR, 2013, p.34)
} 
imaginação, aqui tomada como algo diferente da vã fantasia, que das artes parte para as outras operosidades conferindo-lhe sucesso, tem um ponto de inserção no devir histórico; mas este ponto é de difícil encontro. "O corpo e, portanto, a imaginação, não existe fora do devir histórico, mas flui dentro dele; além disso, é por ele inteiramente atravessado e constitui-o, constitui-se juntamente com o mundo e os significados" (FORMAGGIO, 1976, p.90). É nesse sentido que a filosofia da arte em Formaggio propõe um materialismo que justamente interessa à natureza de minha abordagem. Este materialismo que, do ponto de vista da natureza da estética - portanto ainda vocacionada à arte e à possibilidade da obra - pode trazer toda uma abundancia de possibilidades de abordagem. Não penso que há uma 'evolução' ou uma hermenêutica 'progressiva' entre Heidegger e Formaggio. Penso que a estética pode, a partir destas três contribuições, obter caminhos. Caminhos que não se cristalizam enquanto um corpus bem delimitado; mas que dentro da possibilidade de se pensar uma nova possibilidade de definição de arte para os dias de hoje são relevantes cada uma à sua maneira. E no caso de Dino Formaggio, me parece uma verdadeira empresa essa reação materialista ocorrente a partir de um pensamento eminentemente filosófico. Aqui, o corpo, tido como algo de negado, ressurge.

\begin{abstract}
E eis que o corpo se move e arremessa com solicitações, intenções, relações, redes de sentidos, de percepções-imaginações-memórias e, no seu movimento, abre o vazio diante de si, o vazio da sua própria figura, o vazio das sua própria estrutura de necessidade, para iniciar a luta, recomeçando sempre do princípio, dos preenchimentos de sentido, semeando por toda a parte os signos da sua passagem e do seu reconhecimento para reencontrar, de cada vez que regresse, a estrada. É com o seu próprio movimento que o corpo sai do medo originário e começa a traçar os seus próprios caminhos. Então, cada direcção especifica-se, carrega-se de significado, revela-se amiga ou inimiga, torna-se sagrada, isto é, excepção do espaço, ou profana e indiferente. $\mathrm{O}$ espaço mágico inicia a qualificação do mundo e começa a formar regiões cultuais e culturais típicas. Também o tempo sagrado dos festins se torna excepção, fora do devir uniforme. Constituem-se espaços e tempos determinados, carregados de emotividade ontológico-existêncial (vários espaços e tempos, mítico-sensíveis, que a arte deverá frequentemente por em acção) (FORMAGGIO, 1976, p.77).
\end{abstract}

E quando esses espaços postos em ação pela arte se realizam, dá-se uma inserção material no mundo que preserva sua estrutura de trabalho, de labor. Essa, para o filósofo, é social e não alienada dos problemas do mundo material. É assim que se daria então, nesta visão, a aventura da arte; pela entrada na coisa material, pela imersão nela da própria praxis, dando-se assim, o nascimento do novo significado. Na matéria, então, está o reconhecimento a ser procurado. Mas implica, por consequência, um outro tipo de 
compreensão, que não se traduz necessariamente na noção de autonomia, uma vez que "a matéria como inércia natural ou social e destruída como Outro e elevada à categoria do si próprio, enquanto o si próprio, por sua vez, desfaz a própria alteridade ou alienação precisamente no ato de se projetar".

Neste sentido, só há a possibilidade de que o encontro se dê "como reconhecimento, justamente porque é como matéria sensível e corpo (matéria natural e social) que o homem encontra a materialidade natural para a transformar em artística" (FORMAGGIO, 1976, p.123).

Enfim, Formaggio demonstra qual é, no sentido de sua abordagem, a natureza da arte, quando sobre a obra enquanto ação da possibilidade projetual diz:

Trata-se de uma forma especial de práxis, que tem a ver com as matérias. Cria, a partir das matérias, dos significantes, e entretece-os num desenho que torna transparente a opaca dureza do real, permite olhar-se através, estabelecer um universo de interpretação e de sentido de determinados grupos signicos (FORMAGGIO, 1976, p.72).

Essa filosofia da matéria e do corpo, em Formaggio, se desdobra no sentido de considerar que a "arte é um problema de plenitude humana e de intercomunicabilidade social no próprio ato de se colocar" (ibidem, p.122), numa estética que inclui uma visão a partir do materialismo histórico no que diz respeito a este "ato de se colocar". Tal desdobramento, embora importante, não será examinado aqui. Considero que, para o que pretendo extrair - justamente uma definição e uma recuperação de determinados sentidos da arte - a inclusão de um materialismo marxista ideologicamente marcado e expressivo de um determinado momento histórico foge ao escopo desta abordagem, embora pudesse bem servir a outros propósitos colaterais.

Por hora, no caso específico de Formaggio, é importante que se extraia justamente uma noção socializante da arte a partir da estética que considero exemplar:

Em vez de ser, como muitas vezes se supõe, um vício solitário, a arte tornase, assim, um hino à vida associada, um testemunho da potenciação que os quadros sociais operam, no trabalho, sobre o homem e sobre a sua inserção eficiente e justa na projectação de novos significados. (...) A matéria, para a arte, na sua dupla forma de materialidade natural e de materialidade social, não é um sonho mau, um pesadelo do qual fugir, um fantasma pecaminoso a exorcizar, mas o seu sustento, a sua vida. A materialidade natural entra na arte não só como algo informe a que dar forma, como algo destituído de sentido a que dar sentido; mas, como processo já em acto de formas e sentidos (FORMAGGIO, 1976, p.122). 
Temos, sem dúvida, um modo de operação na obra que é ao mesmo tempo artístico e social. Mas a negação de um idealismo não se dá na dispersão radical do sentido de arte ou de obra de arte enquanto um campo e um fazer diferenciado. Antes, à essa premissa se junta uma ideia de expressão a partir da objetivação do corpo na matéria. Penso no sistema de Dino Formaggio como exemplar justamente por promover uma inserção do problema social dentro determinados limites onde a estética não se transforme em uma outra disciplina, tampouco sem desprezar os dados de outras disciplinas, mas sem excluir a especificidade da arte ou da obra. Ele mesmo assevera sobre o que considera um risco, justamente uma abordagem que tende a não considerar a natureza específica da arte:

\begin{abstract}
Isto levou, na nossa época, a submeter um acto extremamente delicado e qualitativo, como é o da projecção, a toda uma série de tentativas de controlo. Neste, como noutros domínios, tentou-se, com efeito, submeter a um controlo cientifico, estatístico e probabilístico, a técnica de produção e os produtos da projecção artística, sem se ter em conta que, precisamente deste modo, a força da possibilidade projetual era eliminada do próprio plano da possibilidade e colocada já morta sobre a mesa de autópsia do controlo repressivo de uma tecnologia desumana. A possibilidade sem liberdade, morre: pode obedecer à necessidade das próprias leis enquanto as inventa, pois a liberdade é auto-necessidade, mas não a imperativos e leis exteriores, porquanto estas suas leis não são arbítrio veleidoso mas sim, por sua vez, obediência, através de conhecimentos sensíveis e de intuições imaginativas, às leis de constituição de significados. Aqui reside a sua funcionalidade significativa, que respeita, mesmo nas suas rupturas mais radicais, a lei dos co-possíveis. A projecção artística, quando submetida ao controlo dos grupos de ciências, quer naturais, quer antropológicas, como a psicologia e a sociologia, resulta alienada e, portanto, obscurecida na sua produção e nas suas obras (FORMAGGIO, 1976, p.71).
\end{abstract}

Ora, se tomarmos as três linhas mestras através das quais ao longo da história, se perfizeram as definições de arte no ocidente, conforme as apresenta Luigi Pareyson; e se pensarmos a possibilidade de trazermos o exame destes que considero os filósofos através dos quais elementos para uma nova formulação estética possam ser apresentados enquanto possibilidade, poderíamos ter uma definição de arte que parta da seguinte associação, que a mantêm ainda como campo específico. A arte residiria, ao mesmo tempo e sempre, nessas imbricações:

\footnotetext{
* um conhecer

* um fazer

* um exprimir
} 
que podem se manifestar, de forma intercambiante, como: um desvelar (Heidegger), um formar (Pareyson), um corporificar/materializar (Formaggio).

Aqui, já é possível perfazer uma definição de arte.

\section{Música, algumas implicações: liquidez, metalinguagem e uma teleologia negativa $^{70}$}

Nestes breves estudos, que sobretudo buscaram examinar sistemas que apresentam o campo da arte segundo certos caracteres distintivos, a tendência a uma hermenêutica mais geral da arte engloba grande parte dos problemas relacionados ao arcabouço necessário para uma estética musical ou para uma estética de qualquer outra arte em específico. No entanto, é certo que, no caso de um exame sobre a produção de uma arte em especial - no presente caso a música - é inevitável que certos problemas colaterais apareçam.

A arte enquanto um conhecer, tomada a partir da noção de develar, de desocultar, esbarraria no problema do significado na obra musical? É certo que a recuperação heideggeriana do sentido da $\alpha \lambda \dot{\eta} \theta \varepsilon 1 \alpha$ não se reduz a uma ideia de compreensão e expressão de sentidos vinculados ao discurso linear verbal. Mas é certo também que há a diferença de apreensão de sentido na música puramente instrumental e na música com texto. Estaria esta definição refém da distinção entre música pura e música aplicada? Com certeza não. Toda a estética do sentimento no século XIX, como vimos, se deteve neste problema, que hoje, seria um falso problema. A polissemia da música, independente da forma em que se manifesta e do modo como se relaciona com a linguagem verbal, não condiciona sua possibilidade de desvelar sentidos ocultos nem trazer ao claro a coisidade do signo (o som). Neste sentido, é certo que a vocação da música ao enigma da coisa é possivelmente maior que em outras artes. O seu desocultar pode ser talvez mais imediato do que em qualquer outra arte, e se revela na

\footnotetext{
${ }^{70}$ Usarei essa expressão como uma possibilidade de definição para a natureza da música. Embora a noção de liquidez tenha se transformado num conceito obrigatoriamente ligado ao filósofo Zygmunt Bauman, não faço a ele alusão quando uso esta expressão. Aqui, trata-se do caráter permeável e permeante da música enquanto arte do som no tempo, principalmente aludindo às possibilidades que apresenta a música no sentido de fusão orgânica com outras artes.
} 
multiplicidade de interpretações, o que revela um paradoxo que, de saída, demonstra a dificuldade da empreitada: a vocação da música para a pura forma se relaciona dialeticamente com a ocultação radical de seu processo formativo (pensemos numa sinfonia de Beethoven). No entanto, é possível dizer que a música, especialmente a instrumental, tende a ser tomada na apreciação de seu engenho, de sua estrutura, já que o sentido de linguagem (tomada em sua antiga acepção, de faculdade de articulação verbal do pensamento) ou está em uma relação complexa com a realização sistemática da obra ou está ausente; neste momento, o que temos é uma aparente contradição: a ausência de sentido ou a presença de múltiplos sentidos? Cairíamos novamente no problema da dicotomia novecentista. A superação deste problema se daria justamente quando pensamos que, em sendo poesia - esse formar que é puro êxito - a essência da arte encontra o seu logos em cada arte em particular. O desvelar não está condicionado ao problema da linguagem compreendida em sua antiga acepção, aderente à articulação da linguagem verbal e escrita mensurável dada numa articulação de significados. Em arte, linguagem é essencialmente metáfora. É o fazer que se realiza na técnica (como em Formaggio) e no artesanato que é a própria substancia condicional da poesia. Em outras palavras, trata-se de exposição de mundo e não especialmente de uma ad litteram da linguagem. Formaggio propõe que a mecânica brutal que associa arte e linguagem, confundindo-as, ignora que a clara distinção entre a linguagem referencial (informativa) e a linguagem poética (artística) é condicional para que se supere preconceitos familiares, que atentam contra o caráter formativo da obra. ${ }^{71}$

Em certo sentido, falar em termos de linguagem é dispensável. No caso da música temos como um caminho possível a ideia de superação da lógica de um sistema, postulado do musicólogo Rubens Ricciardi (2013), que parte da premissa de que o desocultar, no caso da música, se dá a partir da noção de que há uma normativa mediana na produção das obras musicais, que a partir das regras estabelecidas para os seus sistemas artesanais, se coagulam em poéticas gerais e lógicas reguladoras e fechadas. A

\footnotetext{
71 "A formulação da identidade arte-linguagem é, efectivamente, a mais genérica e decorre não tanto do facto de existir uma arte da linguagem (como a poesia), que não implica que a arte seja linguagem, tal como a existência de uma arte do bronze não implica que a arte seja bronze (...) quanto do pressuposto de que "a obra é um discurso que pressupõe um certo código e de que através da obra o artista fala". Dois preconceitos que são anulados por uma observação atenta da experiencia artística: esta, no que se refere ao primeiro ponto, revela que a obra de arte não tem sistemas legislativos codificados e normas que a precedam; e só à medida que se faz, momento a momento, a obra de arte toda a obra, se atribui a sua lei e constrói as normas válidas para avançar, respondendo sempre não já a uma necessidade como coacção externa, mas a uma obrigação moral interna própria e, pode-se-ia dizer, auto-legisladora" (FORMAGGIO, 1976, p.133).
} 
superação destas normas é a possibilidade da retirada da obra do arcabouço normal dos sistemas operativos estabelecidos ${ }^{72}$. Em outras palavras, a emersão ou desocultação de uma harmonia inaparente seria a condição para que a obra musical fosse da regra à exceção. No combate entre a existência necessária de uma lógica normal e a sua 'quebra', se daria o sentido da superação da lógica de um sistema musical, rumo à sua especificidade enquanto $\operatorname{arte}^{73}$. Se esta associação entre expressão e desocultação que proponho faz sentido; se este passo adiante, que considera a obra de arte musical consubstancial à superação da lógica de um sistema é efetivo; e se linguagem, no sentido de cada arte em específico é uma metáfora para a realização do logos, então a sugestão de Ferreira Gullar pode ganhar ainda mais relevo:

Podemos definir o âmbito da linguagem em termos de sistema (elementos, relações, princípios, etc.), mas não em termos de expressão: E a linguagem da arte se empobrece, se academiza, precisamente na medida em que o sistema prepondera sobre a expressão: a linguagem "se fecha" (GULLAR, 1999, p. $67)$.

Neste sentido, para a realização da obra musical, não há qualquer necessidade de sentidos e significados articulados enquanto linguagem verbal, nem de uma concretização ideológica perceptível de forma imediata ${ }^{74}$. Se de fato as relações de Heidegger com relação ao mundo da obra, dos apetrechos, da mera coisa, puderam nos legar um pressuposto para uma definição de arte que tem entre as suas prerrogativas a ideia de expressar enquanto desvelar, também a de Pareyson, com sua proposta teorética de compreensão da obra enquanto formatividade, um fazer diferenciado, já que “o simples fazer não basta para definir sua essência. A arte é também invenção. Ela não é execução de qualquer coisa já idealizada, realização de um projeto, produção segundo regras dadas ou predispostas. Ela é um tal fazer que, enquanto faz, inventa o por fazer e o modo de fazer" (1997 [1966], p.25-26), contribui para a libertação de um idealismo tomista da criação, trazendo ainda a vantagem de vermos a diferenciação da obra do mundo das coisas a partir de uma ótica onde o artista se faz expressão no estilo. Essas

\footnotetext{
${ }^{72}$ Também em Gullar, referindo-se à atividade do artista: "É certo que, na pratica da arte, o artista termina por adquirir um domínio de seus instrumentos de expressão, uma técnica, mas o que define os grandes artistas é precisamente sua capacidade de se sobrepor à técnica, de dar a volta por cima, isto é: um domínio tão profundo da técnica que a anula como eficácia, impedindo assim que sua linguagem se esclerose" (GULLAR, 2006, p. 111).

${ }^{73}$ Os exemplos abundantes dados por Ricciardi se dão no âmbito da análise da comparação entre o que seria uma determinada obra se composta dentro da lógica do sistema e como esta se dá na superação desta lógica (RICCIARDI, 2013, p.43-46).

${ }^{74}$ Eis o cerne do problema da música politicamente engajada. Na realidade, de toda arte engajada.
} 
duas linhas que, de modo geral convergem e se complementam, quando utilizadas para o pensamento sobre música, trazem a necessidade de um pensar que leva em conta as especificidades do logos musical. Se esses pressupostos dão conta de uma gama muito ampla de experiências estéticas, é certo que, por mais que se trate de hermenêuticas gerais da arte, ainda não atingem um ideal de pureza teorética ${ }^{75}$, de aplicabilidade universal. Essa inclusive não é a sua desvantagem. Pelo oposto, é a constatação de que não existem epistemologias e nem relações epistemológicas suficientes para dar conta do fenômeno (o que redundaria em uma tautologia, como vimos), muito menos definições de arte que esgotariam o exame do fenômeno. Dino Formaggio, ao se negar uma definição de arte (arte é tudo aquilo a que os homens chamam arte), preferindo se ater a uma análise da experiência artística dada no expressivo histórico, já reconhece essa dificuldade empreendedora. Fico no entanto consolado com a asseveração de Eco, já apresentada, segundo a qual ainda vale a pena a tentativa de uma definição. E, se a estética deve partir sempre da experiência da arte - assumindo tanto o sentido de Formaggio quanto o de Pareyson - também encontro um sentido mais antropológico e etnográfico, por assim dizer, quando a minha própria experiência artística 'invade' o exame. Trata-se, no presente caso, de uma forma de estabelecer uma relação do geral com o particular. Trata-se da permeabilidade da modernidade atual: sujeito e objeto vão se confundindo. Assim, opto por uma ironia: Formaggio pode também complementar um sistema que aventa a possibilidade de uma definição para a arte.

Então, a última extração de um postulado, no caso a que realizei a partir de Dino Formaggio, pode contribuir como uma abertura epistemológica, um modo de compreender o que a música, dentro da tradição em que a tomamos, perdeu e precisa recuperar (por conseguinte dando pistas de como pode se dar uma estética concatenada com outras disciplinas). De fato, uma outra interessante questão pode ser levantada com respeito a especificidade da música: essa compreensão da obra enquanto apartada da técnica artística, mero meio para se chegar a um fim, essa separação dada historicamente entre a obra de arte e o trabalho, talvez seja mais latente na música do que em qualquer outra forma de arte, e o percurso da arte musical pode muito bem ser exemplar desta linha de pensamento que visa agregar o corpo à obra. A separação entre o labor e o puro êxito é a própria negação da técnica artística (sempre expressiva de um

\footnotetext{
${ }^{75}$ É justamente essa a censura de Formaggio à Teoria della Formatività de Pareyson: uma suposta pretensão de pureza teorética. Umberto Eco analisa as argumentações em torno destes problemas (ECO, 1972).
} 
tempo histórico) como parte da obra. Então, ela também é negação da corporalidade. Penso ser perfeitamente possível uma leitura da história da música ocidental que parta da totalidade nas manifestações da ovбıкn่ ou mesmo das manifestações musicais de todas as culturas antigas adjacentes, mesmo as do oriente - estas onde o corpo sempre esteve presente no rito - à negação paulatina do corpo e da matéria. Se me aproprio de certas noções básicas da estética de Formaggio, especialmente àquelas ligadas às questões da técnica artística, da matéria e do corpo, e aplico-as ao problema da especificidade da música e seus desdobramentos na história, torna-se possível reconhecer uma contradição. Na realidade uma dialética bastante complexa: o corpo desfere a flecha da imaginação projetual, que fere a realidade, expondo o mundo de suas possibilidades na obra. Neste sentido, é do corpo que nasce a arte.

No entanto, a música, em se tomando o caminho tradicional do pensamento que perfaz o seu desenvolvimento, se desdobra a partir, ironicamente, de uma paulatina ocultação do corpo, uma negação, até mesmo. Claro deve ficar que não considero este caminho "tradicional" nem como o mais verdadeiro nem como o único: da Grécia ao cantochão, do Renascimento ao serialismo. Obviamente este percurso apresentado didaticamente como sendo a 'História da Música Ocidental' é um constructo artificial consubstanciado em leituras canônicas que se imbricam de muitas formas e representam tanto as leituras históricas e ideológicas expressivas de uma época, como leituras $a$ posteriori que pretenderam legitimar determinadas linhas de pensamento em detrimento de outras ${ }^{76}$. Mas em sendo ele, malgrado as nuances e leituras matizantes, ainda o paradigma (apesar de todo um movimento disciplinar crítico nos últimos anos), é certo que, do ponto de vista da estética é interessante tomá-lo por objeto e identificar nele a pregnância de determinadas constantes que colaboram tanto para a sua fixação por vias exteriores - a história do pensamento sobre música - como a partir do próprio objeto: o gradual desdobramento do saber técnico específico nas poéticas.

Foi a partir da imbricação de um e outro que possivelmente se estabeleceu a lógica deste caminho que assim compreende a "evolução" da música. Estabelecer uma relação de causa e consequência é evidentemente impossível. São as leituras cada vez mais tendentes à percepção do elemento racional que identificam uma linha coerente

\footnotetext{
${ }^{76} \mathrm{~A}$ partir do estudo de William Weber (1999), é possível depreender um complexo movimento de diacronismos que legitimam de muitas formas essa ou aquela manifestação. Weber desconstrói não só o canone mas a própria crítica do cânone. Ele pretende lançar uma epistemologia clara por onde os historiadores poderiam começar, e o modus operandi que seria adequado, uma vez que a própria história da cânone possui seu próprios vícios.
} 
que vai do mais simples ao mais complexo, do menos desenvolvido ao mais desenvolvido etc., a partir da observação das poéticas, ou as poéticas se desenvolveram neste sentido refletindo o Zeitgeist de sua produção?

Na medida em que estudos mais aprofundados com vias a uma crítica do cânone da música ocidental vêm surgindo, especialmente na Inglaterra, e é neste sentido que as publicações de Cambridge vem se destacando, é certo que cada vez mais amiúde versões diferentes do desenvolvimento - na verdade a partir da própria contestação da ideia de desenvolvimento - da história da música, segundo inúmeras óticas antes não tão exploradas, tem contribuído para a retomada de assuntos relativos a esse mesmo caminho da história da música sob perspectivas muito inovadoras (uma delas usarei mais tarde). No caso de assumirmos uma perspectiva dentro de minha proposta em estética musical, talvez seja o caso de repensar este caminho por uma via que identifique o que ele despreza. Neste caso, a filosofia da arte de Formaggio, em especial naquilo em que pus foco - a questão do corpo, da técnica, do material - talvez revele o que foi negado. Afinal, seriam essas as perdas mais significativas do caminho que a música fez em direção cada vez mais inexorável à síntese? Ao meu ver, sim.

A música ocidental de matriz européia trilhou um caminho que pode ser identificado no seguinte diacronismo: por um lado, temos que após a dissolução da ovoıkn் na ênfase dada ao cantochão, já purificado do corpo e da matéria (é quase pura voz) a partir da estrutura valorativa da palavra, sem a possibilidade de um ritmo que traga movimento, tornado substancial na confissão agostiniana do pecado do prazer quando da música sobressai a carnalidade intrínseca da sensação, o que se tem é uma pregnância platônica não hesitante: um primeiro, e talvez mais poderoso, cânone musical de todos os tempos, que se manteve por muito tempo numa hegemonia cultural que procurou excluir toda a possibilidade de dialética com as manifestações profanas, representando, malgrado sua inegável beleza e importância, a entrada da consciência infeliz $^{77}$ judaico-cristã. Esta consciência, foi quem posteriormente conferiu à atividade

\footnotetext{
77 Tomada no sentido hegeliano por Formaggio (cf. 1976, pág.36-37). Isso se revela como uma passagem de uma consciência objetal para outra subjetal. O cristianismo encampa uma consciência infeliz judaica, subjetivando o objeto, redimindo a linguagem, fazendo surgir, com a morte e ressurreição de Deus, a arte enquanto possibilidade. Então, o artífice é transformado em artista, não pelo seu domínio técnico na objetivação de sua ideia na matéria, mas pela objetivação de sua própria consciência. Essa é uma etapa

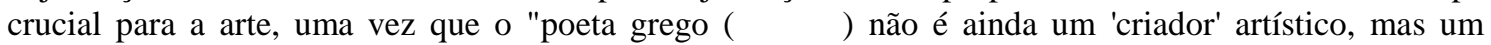
construtor e ordenador técnico de uma matéria de origem divina. Ele tem, precisamente, a ver com a técnica. Só com a nova dimensão da consciência judaico-cristã o termo pode ser associado ao acto criador, ao sentido mais profundo do "criar do nada", segundo a típica conotação que a cultura
} 
artística um sentido de criação, enquanto retirou dela a possibilidade do prazer, do corpo, do êxtase carnal. Por outro lado, foi a partir da admissão gradual da ideia de criação que surge um sentido de síntese na música. Este, ao meu ver, se tornou o caractere mais marcante do desenvolvimento do pensamento na música ocidental consubstanciado nas poéticas: o sentido de um caminho rumo à complexidade e abstração. Quando compor deixar de ser um "pôr junto" e se torna "criar", nota-se que toda a tradição musical e artística busca um sentido sintético na admissão de um polifonia $^{78}$ cada vez mais austera. Isso poderia aparentemente representar um paradoxo. Mas é apenas um deslocamento. Do mundo ideal, o céu, ao intelecto.

É interessante notar que em comparação às manifestações musicais de outras culturas, especialmente àquelas ligadas ao folclore ou às culturas não ocidentais, por mais que a tradição ocidental representasse sempre um caminho para uma simplificação de certos aspectos, dada na padronização rítmico-melódico no gradual estabelecimento de padrões fixos que culminassem em estruturas rígidas, na absorção da mensurabilidade dos compassos, na redução sintética de todas as escalas à duas principais, mas principalmente no temperamento igual desenvolvido no século XVIII, o caráter de voz sobre voz, nota contra nota, enfim, da polifonia, garantiu sempre uma tendência organizacional a partir do maior número de informação em menor espaçotempo $^{79}$. Se é possível identificar esse caminho que agrega em termos de síntese enquanto simplifica em termos de corpo, talvez seja o caso de uma outra construção de sentido; uma que parta de uma noção que enxergue neste caminho uma espécie de teleologia negativa ${ }^{80}$ : um desdobramento da música e do pensamento sobre música que parta de uma negação, a negação do corpo. Primeiro através da própria dissolução da ovбıkท่. Depois, na paulatina adesão da cultura cristã ao platonismo. A filosofia da música primordial no ocidente, que revela Boécio no início do século $\mathrm{VI}^{81}$, é pregnante de um sentido grego que nega o labor e relega a atividade corpórea, aquela direcionada

contemporânea, especialmente a romântica, como se sabe, deu ao termo poesia, e reflexamente, ao termo arte (p.37).

${ }^{78}$ Weber (1999) estabelece uma relação entre a construção de um cânone e o estabelecimento da polifonia.

79 Para conter um mesmo número de notas do que 10 minutos de uma sinfonia de Villa-Lobos, por exemplo, talvez fosse preciso horas da música monódica folclórica, ou japonesa tradicional.

${ }^{80}$ E aqui vai uma ironia: se pude realizar uma crítica da teleologia de matriz germânica que criou uma linha evolutiva, legitimada pelo pensamento estético do século XIX, posso aventar a possibilidade de combatê-la dentro de seus próprios limites, propondo uma inversão se sentido.

${ }^{81}$ De institutione musicae (ca.500) propõe a separação da música em três universos: música mundana (harmonia do macrocosmo, música inaudível), música humana (harmonia que diz respeito aos homens, microcosmo) e musica instrumentalis (música a partir da praxis). Aquela relativa à praxis, ao labor e ao trabalho, está abaixo das demais, representando o grau mais inferior na divisão dos universos musicais. 
a uma função, ao plano inferior. Embora a direção da música aponte um caminho ao intelecto, para a ideia de coisa mental, e embora as flechas que partem do corpo sejam aquelas que ferem a realidade projetando nela possibilidades que se consubstanciam em obra, é certo que a passagem do artífice para o artesão que se dá no início da era cristã se desdobra na passagem do artesão para o artista criador durante o Renascimento.

Essa mudança é determinante do que pretendo examinar: não só a música, malgrado a sua gradual secularização e adesão do mundo profano, é marcada por uma consciência artística que é auto-consciência, como por uma libertação e autonomia do artesão, agora artista de posse de uma técnica específica. Essa vocação descoberta pela arte não só é uma outra marca da negação do corpo como se transforma em linha mestra por onde se desdobrará toda arte ocidental. Essa autoconsciência que a arte lentamente desenvolverá enquanto reconhecedora e propulsora de significados relativos ao seu próprio processo formativo pode fornecer, penso eu, dois elementos fundamentais pelos quais podemos compreender os caminhos que fizeram a arte contemporânea e a música de hoje apresentar os problemas que ela apresenta, e que a estética deve tomar como experiência: em primeiro lugar, a dissolução da ovoıkn talvez seja uma espécie de atentado à especificidade de sua essência, que reside, ao meu ver, em sua capacidade amalgamadora, a sua possibilidade de ser uma com outras artes, a sua permeabilidade enquanto arte do tempo, enfim, ao seu jorro de significados: sua liquidez.

A negação de sua totalidade originária, especialmente no que diz respeito à adesão do corpo e da matéria (algo compreensível quando falamos da arte do som no tempo), rumo à solidez e consistência, não seria, de saída, uma negação de sua essência? Não é este caminho que encontra sua finalidade no recrudescimento de uma linguagem fria e baseada numa lógica de sistemas, cujas filiais, a partir do século XX, abandonam de tal maneira a relação com o mundo material que chegam à dispensar o intérprete? Ou até mesmo o ouvinte? Decifrar toda uma poética pela escuta é mais que uma proeza. $\mathrm{Na}$ música, esse desvelar sempre tendeu a uma noção de produção como engenho: sua percepção como uma técnica é mais aguda, conforme seu material é mais oculto. Por isso outro paradoxo: na música, em especial a dita 'pura' se mostra mais evidentemente esse puro êxito, este formar por formar. A tendência de tomá-la a partir do fazer é sempre mais iminente. Mas como arte do som no tempo, esse fazer se materializa mais na memória prescindindo de uma concretude estática, o que nos leva à um caráter eminentemente líquido. Talvez caberia melhor aos estudos históricos e sociológicos um 
exame sobre as razões desta liquidez tender aos poucos à consistência, verificando empiricamente o que aqui verificamos especulativamente.

A partir dos primados do cristianismo, o distanciamento do corpo que se transformará em uma tomada da música como coisa intelectual, passa aos postulados de autoconsciência da arte no sentido de sua aproximação com o mundo da ciência ${ }^{82}$. Espero que esteja claro que traçar este caminho por via negativa não deve se confundir com uma crítica. Na realidade tomei a existência da obra musical a partir do postulado que considero especialmente justificador do que tento empreender, de que a arte e a obra de arte existem. Em se tomando os sentidos que a arte veiculava no arcabouço do pensamento grego, já se verificam todos os parâmetros de depois. Mas a resemantização do sentido de poíesis especifico desta autoconsciência (já verificável no seio do pensamento aristotélico) se revelará nesta etapa de consagração da autonomia da obra e do artista a partir do Renascimento: só assim se verificará com clareza que "o ofício [de artesão] tem uma curiosa prerrogativa: pode existir sem a arte, enquanto, pelo contrário, a arte não pode passar sem ele" (PAREYSON, 1997 [1966], p.171).

Eis que, se se pode reler a história da música segundo a dialética afirmaçãonegação do corpo, após uma primeira etapa (do artífice ao artesão), a autoconsciência da arte a partir da consideração de um domínio técnico diferenciado do artesanato ocorre via esta mesma dialética: a liquidez se recrudesce quando a arte tem ciência de sua ciência; e quer mostrá-la. Aqui, temos essa vocação da arte e da música cuja pregnância pode levar à diversos resultados, e no que interessa aqui, ao estabelecimento de uma linha hegemônica: um espécie de vocação à metalinguagem, que aparece em segundo lugar.

\footnotetext{
${ }^{82}$ A liquidez da ovбıкท่, permeável à dança, literatura, teatro, enfim, ao realce de sua totalidade a partir de sua permeabilidade, caminha, após a negação do corpo, rumo às dicotomias: palavra versus música no início do século XVII; música instrumental versus música aplicada a partir do século XVIII; no século XIX, a recuperação desta 'permeabilidade' poderia ter logrado na ideia de arte total. No entanto, como foi possível demonstrar a partir do exame sobre música absoluta na primeira parte, o que se teve foi um idealismo cultural em vias de se estabelecer. A música programática ou o drama musical, no sentido desta permeabilidade, não seriam a sua consubstanciação: somente uma tentativa datada de estabelecimento de uma linha evolutiva cujo fim é autoproclamado. Vale lembrar que, não obstante o texto literário ou pictórico de apoio (o programa), a música conteudista, não absoluta, é justamente música instrumental 'pura', portanto absoluta; e não obstante a existência de uma profusão de artes no drama musical wagneriano, seu ideal é justamente o da música absoluta, bem notado por Nietzsche, um absoluto metafísico, portanto mais do que impermeável. A própria consideração da música conteudista/programática como sendo aquela que se associa à elementos extra-musicais (o que se aplica ao drama musical) especialmente propalada nos postulados de Liszt e Wagner, revela que os outros elementos não permeiam a música, justamente por serem "extras".
} 
Não me refiro aqui à metalinguagem no sentido de uma formulação conceitual precisa (aliás, já realizada por outros autores) para a análise de um determinado problema. Antes, pretendo pôr em relevo a hipótese de que um caractere específico surgido no percurso das poéticas artísticas em suas emanações históricas possa ter assumido uma posição paradigmática tanto na elaboração das obras quanto no exame dessas elaborações. É possível localizar especificamente na arte e no contexto social do Renascimento, especialmente na Itália, a descoberta desta autoconsciência da arte, e da tentativa de demonstrá-la. Como o já dito anteriormente, não por acaso essa autoconsciência se desenvolve no período de início de emancipação do artista-artesão. Em música esse processo de emancipação demorará pelo menos até os anos do século XVIII, no entanto, a mudança já deflagrara a partir do período entre o século XIV e XVI. Nas palavras de Formaggio: "O caráter fundamental da nova figura da consciência artística que se constitui, sobretudo, nos primórdios do Renascimento italiano, consiste, justamente, nesta unidade de executar e de reflectir cientificamente sobre a execução e na própria execução." (FORMAGGIO, 1976, p.41).

Neste sentido, não é de se surpreender que no ápice das conquistas artísticas do Renascimento pôde surgir uma obra tão paradigmática como $O$ Engenhoso Fidalgo dom Quixote de la Mancha de Miguel de Cervantes. Penso que essa obra é exemplar de tudo aquilo que pretendo expor: toda elaboração literária de Cervantes procura deflagrar a forma e a operação formativa da construção da obra. O exercício metalinguístico aqui é de tal maneira prenho de suas possibilidades que o desenvolvimento da estrutura parece se dar a partir da complexa dialética que deixa em seu conteúdo aparecer a crítica aos antigos romances de cavalaria enquanto se deixa pistas de como se está realizando um exemplo bem acabado de alternativa a estes romances: ao mesmo tempo inventa-se e se mostra como inventa. A complexidade se dá quando a própria obra responde aos estímulos externos, da vida (especialmente no segundo volume), refletindo no próprio conteúdo ficcional as imbricações entre realidade e realidade da arte (metaforizado na personagem de dom Quixote). ${ }^{83}$ Cervantes parece estar pleno dessas possibilidades quando num diálogo entre Sansón Carrasco, Sancho Pança e dom Quixote surge a especulação: "Mas uma coisa é escrever como poeta, e outra como historiador. O poeta

\footnotetext{
${ }^{83}$ Em determinado momento da saga dom Quixote, ao assitir um teatro de títeres com sua própria história, o anti-herói confunde arte e realidade invadindo e destruindo a apresentação. A arte como uma continuidade da realidade nunca foi melhor retratada. Formaggio realiza uma profunda reflexão sobre esse continuum entre arte e realidade no sentido da complementaridade. Trechos de Proust e outros autores são usados como exemplo (cf. FORMAGGIO, 1976).
} 
pode contar e cantar as coisas, não como foram, mas como deveriam ter sido, e o historiador as há de escrever, não como deviam ser, mas como o foram, sem aumentar ou diminuir a verdade em ponto algum ${ }^{84}$." Aqui, está claro que o poeta (o autor) esta inventando um mundo outro, mas mostrando o processo na personagem (dom Quixote), e imbricando suas intenções segundo estímulos da realidade.

Formaggio demonstra em termos mais claros essa dinâmica que é gradual, mas inexorável:

\begin{abstract}
A arte, no seu progressivo tornar-se consciência que avança, de si própria e da própria lógica, pôde, por vezes, tentar passar a ciência, não a ciência do real, de uma constituição em realidade, mas antes a ciência de si e do possível real que é a possibilidade projetual. O possível real não é o real, ainda que se coloque como uma das suas dimensões constitutivas e postule um real mais que real, uma vida mais que vida (FORMAGGIO, 1976, p.72).
\end{abstract}

Se de fato "a realidade material do signo está quase sempre oculta pelo significado, muito embora participe dele" (ibidem), é a partir deste contexto de demonstração na obra da feitura da própria obra que se vê o início (ou será que esta sempre foi uma vocação da arte?) de uma guinada surpreendente onde o corpo que desfere e ao mesmo tempo é negado na obra deixa sua impressão projetual no exato sentido de que esta fique à mostra enquanto processo, não enquanto significado que embota o sentido da coisa. Em outras palavras, tomando o sentido heideggeriano, o desocultar que trás ao claro a coisidade da coisa (ou um real mais que o real em Formaggio), ao deixar cada vez mais o seu processo no claro, tende a um desocultar que é ao mesmo tempo a verdade do enigma e a chave que o desvenda. Em sendo essa hipótese plausível, a obra de arte começa a querer ser "coisa" paradoxalmente quando, autoconsciente de seu processo formativo, quer mostrar como e porque ela não é mais coisa.

É sintomático quando "Michelangelo, deliberadamente ou não desfizera essa ilusão ao deixar inconcluso o rosto de uma das figuras que constituem o túmulo dos Médici, em Florença. É como se dissesse: eis a matéria informe de que parti para criar essas formas perfeitas". Se "a tela ou a pedra quase desaparecem, assimiladas pela imagem em que se transformaram" (GULLAR, 1999, p. 36), o caminho que começa a ser traçado é rumo a um combate entre a ocultação e a desocultação do engenho.

\footnotetext{
${ }^{84}$ O Engenhoso Fidalgo dom Quixote de la Mancha. (pág. 522). 2005. edição comemorativa. Editora Itatiaia. Eugênio Amado (tradução), Belo Horizonte.
} 
Neste caso, a arte como um conhecer é arte como um desocultar do fazer. É na direção do desenvolvimento gradual dessa dialética que o conhecer também é desvelar. Ganha-se com a visão de que a técnica artística não é mera mediadora, mas o desocultar da técnica mantêm ainda afastado o corpo e a matéria, já que aos poucos o conhecimento específico da técnica flerta com a lógica do sistema, enquanto o corpo, ao menos no caso da música, continua a ser afastado em prol da valorização do engenho: o rigorismo musical desenvolvido nas técnicas e sistemas composicionais cada vez mais escolarmente organizados em tratados, e a consciência da arte musical enquanto linguagem científica ${ }^{85}$ deixam cada vez mais claros a necessidade de que a música se mostre também enquanto engenho, numa pregnância pitagórico-platônica que, às vezes mais às vezes menos evidente, deflagra mais um aspecto de sua natureza dialética.

Temos, neste ponto, a possibilidade de uma conexão com o que foi apresentado em meu exame inicial, do alvorecer da estética, por onde comecei na primeira parte deste trabalho: o prelúdio é poslúdio, e no caso da música, contaminada pelo inefável mas fundamentada em suas antigas metafísicas, vê-se novamente, como num movimento circular, que:

Foi talvez no campo da música que as estéticas do inefável se entregaram com um ímpeto mais livre à divagação literária sobre o mistério da arte. A presença de um discurso aparentemente desprovido de significados, privado de equivalentes verbais rigorosos, deixava facilmente entender que nos encontrávamos perante uma espécie de livre germinação do imponderável, uma linguagem nascida dos sentimentos na sua imediaticidade pré-verbal e pré-categorial, um reino da efusividade pura. Por outro lado, o âmbito da comunicação musical é o que se presta precisamente a ser estudado com a chave oposta, segundo o outro caminho da bifurcação anunciada, e por razões que qualquer estudante de solfejo, qualquer modesto intérprete e qualquer compositor sempre souberam, para aquém das superestruturas filosóficas das estéticas românticas: obedecendo a regras morfológicas e sintáticas de uma precisão absoluta e absolutamente impossíveis de transcreve, o discurso musical, antes de ser o lugar de um mistério, é o lugar de uma absoluta clareza lingüística (ECO, 1972, p. 164).

Após as pontas se tocarem, podemos prosseguir ainda mais cientes de como, do ponto de vista filosófico, a música pôde ter carregado certas pregnâncias que passaram a ser veiculadas nos primórdios da estética musical. E podemos prosseguir de onde

\footnotetext{
${ }^{85} \mathrm{O}$ rigor do tratamento contrapontistico da polifonia atingida no fim do Renascimento com os madrigais italianos tardios, e com o desenvolvimento da polifonia franco-flamenga, atingiram um tal nível de relação semântica entre música e texto que culminaram na elaboração de um complexo sistema retórico relacionado aos afetos musicais. No século XVIII, a harmonia tonal se encontraria já sistematizada num conglomerado de regras, bem como os sistemas artesanais (arte do contraponto). Mesmo o sistema temperado é efeito deste traçado.
} 
paramos na primeira parte, mas agora mais completos: este caráter de autoconsciência, esta vocação metalinguística que em outras artes pôde levar à desintegração da linguagem é em que medida responsável pelo que se viu a partir do século $\mathrm{XX}$ até os dias de hoje? Umberto Eco, analisando as possibilidades de definição de arte para contemporaneidade, ressalta este caráter:

\begin{abstract}
A articulação da arte contemporânea que, cada vez mais, é reflexão do seu próprio problema (poesia do fazer poesia, arte sobre a arte, obra de arte como poética de si própria) leva-nos a dar-nos conta do facto de, em muitos dos produtos estéticos modernos, o projecto operativo que exprimem, a ideia de uma modo de formar que realizam em concreto, se tornar cada vez mais importante para a compreensão do objecto formado (ECO, 1972, p. 123).
\end{abstract}

Não se pode negar que, se a incorporação desta tendência metalinguística pôde levar a música rumo ao que chamei hermenêutica da consistência, outros efeitos podem ainda ser verificados. Se a música pôde ser examinada pela estética a partir do século XX tomada sob inúmeras elaborações sobre a sua especificidade minha escolha consciente pelo viés da liquidez e da metalinguística ainda pode ser verificada em outros aspectos. Assim, quiçá poderei criar uma relação de causalidade entre a proposta investigativa principal deste ensaio (ou destes ensaios) - aventar caminhos ou rumos para uma a estética musical para os dias de hoje - e uma elaboração talvez um pouco distinta sobre a vocação da música quando pensada dentro de uma formulação que mantenha viva a ideia de que existe arte, mesmo que as definições e conceitos cambiantes se encontrem, mais do que nunca, num movimento constante entre relações dialéticas nas poéticas e nas disciplinas que se utilizam das manifestações a que chamamos arte.

Se essa tomada de um sentido rumo à consciência das estruturas artísticas, na música realizada a partir de um afastamento do corpo, pode nos levar a suspeitar "(...) que estão nestes exemplos os sinais anunciadores do que ocorreria mais tarde com a linguagem da arte ocidental. Uma desvalorização da ilusão (...), e uma valorização do fazer e da materialidade do signo" (GULLAR, 1999, p. 36), é certo que o próprio ideal metalinguístico se consubstanciou em poéticas particulares, como programa de arte. Se por um lado em alguns programas de arte esta nova - que como vimos remonta, pelo menos, ao Renascimento - modalidade é absorvida pela noção de obra de arte como transformação simbólica do mundo, próximas, de alguma maneira, de elementos que 
procurei levantar até aqui, legando obras de inegável modernidade e importância, também é certo que, tomada em formas radicais nas vanguardas artísticas de algumas formas de arte, levou à própria desintegração do conceito de obra ${ }^{86}$, quando a arte busca se libertar do próprio suporte que a mantêm, e caminha do significado, da desocultação, do formar que é puro êxito, da perda total da objetivação da matéria, paradoxalmente, à pura matéria. À coisa. Umberto Eco, sobre Formaggio, aponta que este

\begin{abstract}
(...) segue muito bem, passo a passo, a consciência filosófica de uma autoconsciência poética "ou clareza do conhecimento que, à medida que avança e progride, vai abandonando cada vez mais, até os perder completamente, os níveis da intuição e do sentimento". E encontra já plenamente desenvolvida em Novalis a nova ideia de poesia que deverá vir a presidir a todas as poéticas contemporâneas: "a poesia da poesia, poesia transcendente, acrescida da clarividência do artista conscientemente presente na sua actividade e na manifestação das artes (...) (ECO, 1972, p.126).
\end{abstract}

$\mathrm{Na}$ articulação dessas tendências e vocações na arte musical, que vão se delineando em linhas complexas, não sincrônicas, pode-se identificar uma constante, de fato, uma dupla dialética, como já vimos: entre o corpo de onde parte o movimento para a arte e o corpo que é gradualmente rejeitado; entre a ocultação da objetivação na matéria que provoca a transformação simbólica do mundo e a desocultação do processo formativo, deixando à mostra o 'como' outrora mantido em segredo. Se o corpo e a coisa são tendências à permanência, à manutenção, então esta teleologia negativa ocorre segundo uma conatus sese conservandi que cada vez se transforma mais em conatus intelligende, conforme uma proposição de Dino Formaggio. No entanto, compreendo que as questões que indicam uma metalinguística acontecem segundo não somente uma tendência que leva de uma conatus a outra. Antes, no combate entre ambas. Não me arrisco na manutenção da afirmação de que talvez trata-se de uma questão de essência, que talvez esteja no âmago da $\alpha \lambda \dot{\eta} \theta \varepsilon 1 \alpha$. Mas julgo que talvez trate-se de uma vocação

\footnotetext{
${ }^{86}$ A poesia de Ferreira Gullar, que tem seu pensamento estético apropriado neste trabalho (especialmente nesta segunda parte), é caso exemplar na poesia contemporânea: o seu último livro (pelo menos até o início de 2016) de poesias Em Alguma Parte Alguma (2013) é exemplar de uma poética realizada na "poesia da poesia". Especialmente o poema de abertura, Fica o não dito por dito: "(...) o poeta inventa / o que dizer / e que só / ao dizê-lo / vai saber / o que / precisava dizer". Muitos casos interessantes na literatura poderiam ser ainda lembrados: desde Autopsicobiografia de Fernando Pessoa, a Walt Whitman, Rimbaud, Bandeira, Drummond (o próprio Gullar agrupou poemas desta modalidade em seu O Prazer da Poesia, antologia de 2014. Seria possível ainda discorrer longamente sobre Niebla de Miguel de Unamuno ou sobre a linguagem de Guimarães Rosa ou Joyce; a escultura de Rodin é exemplar. Por outro lado, especialmente nas artes pictóricas, tem-se que "(...) a pintura abstrata surge como consequiência da progressiva redução da linguagem pictórica à sua própria materialidade, ou seja, da progressiva redução dos signos pictóricos à sua condição de coisa" (GULLAR, 1999, p. 37).
} 
ainda em processo, mantendo-se pregnante até os dias de hoje. As artes ainda vivem sob este signo, e essa consciência filosófica pode ser tomada como atual, ao menos em sua concretude. No entanto cabe-me a pergunta: em que medida isso se dará, e se de fato se dá, na música? Quais os efeitos dessa vocação metalinguística? 
SITUAÇÃO DA ARTE E DA MÚSICA NA CONTEMPORANEIDADE: PARADOXOS NA ESTÉTICA DA VANGUARDA 


\section{PARTE IV - Situação da Arte e da Música na Contemporaneidade: Paradoxos na} Estética da Vanguarda

\section{Introdução}

No início deste ensaio, em poucas palavras, delimitei um território de atuação: a música a que iria me referir era aquela cuja tradição remonta aos inícios do que se convencionou chamar como cultura ocidental, cujos desdobramentos foram muitos e se deram de muitas maneiras, e que na virada do século XX explodiu em diversas tendências, tendo, no entanto, numa delas (como ocorreu em todos os tempos), algo de permanência forçada, de manutenção e perpetuação cuja pregnância ainda hoje é forte.

Procurei tatear por entre os meandros da estética musical e seus iniciais desenvolvimentos em coisas que justificassem determinadas leituras e esta mesma tendência à manutenção. Essa música a que se dá muitos nomes - música ocidental de concerto, música erudita, música clássica, etc. - e que nas manifestações de hoje se vê em uma complexa rede de relações para a manutenção de sua existência: a sobrevivência na sociedade de consumo ${ }^{87}$, e isso é certamente um problema mundial; a

\footnotetext{
${ }^{87}$ Se inclui, neste ponto, as inúmeras - e penso eu, infecundas na maioria das vezes - dicotomias entre música popular e erudita. Penso que se pode, especialmente no caso do Brasil, dizer que existem universos diversos por onde as manifestações musicais se dão. Não pretendo aqui me deter em um exame que pretenda estabelecer normas para estas distinções. De algumas formas pude trabalhar com alguns destes preceitos em minha dissertação de mestrado (GALON, 2011), quando buscava, na ocasião, compreender o fenomeno do neofolclorismo na música de concerto por um viés estético. Mas se é certo que a experiência musical brasileira inclui uma gama muito grande de possibilidades de distinções, também é certo que o conceito de música popular é bastante redutivo quanto temos, pelo menos no Brasil, um universo da canção de tal maneira peculiar e desenvolvido e relacionado historicamente com o mundo dito "culto", intelectual e acadêmico, que fica difícil encaixá-la em elaborações estanques. Esse universo da música popular compreende um número tão variado de manifestações que torna a empresa de delimitálo uma tarefa até mesmo perigosa: a música popular brasileira compreende desde as manifestações da cultura oral, não grafocêntrica, folclórica e ao mesmo tempo a sofisticação de compositores como Tom Jobim, Pixinguinha, Milton Nascimento. Temos essa música popular urbana, altamente desenvolvida enquanto parâmetros musicais referenciados em múltiplos universos musicais, grafocêntrica e fonocêntrica, enquanto temos uma música propagada por tradição oral, dos meios rurais ou fora dos centro urbanos, cujas manifestações se dão de outras maneiras. À parte, a chamada música erudita, confinada às salas de concerto tradicionais ou às universidades. Apesar da riqueza da música de concerto brasileira também não ser redutível a um só aspecto, é certo que parte desta riqueza se dá justamente nas apropriações da cultura popular (urbana, folclórica etc.). Quando em meio a estas dificuldades ainda temos a hegemonia absoluta da música de consumo da indústria da cultura, que atenta contra as manifestações de cultura regional e popular tanto quanto nas ditas artísticas da sala de concerto, quase podemos ceder às simplificações, e é essa a minha crítica às dicotomizações redutivas que buscam separar os campos de forma tão estanque que, de um lado, vemos uma mecânica que tende a uma redução da música popular à música de consumo. Como associar Elomar Figueira de Melo ou Guinga às estruturas da indústria da cultura? Por outro lado, uma espécie de vingança: a associação mecânica de qualquer manifestação dita erudita ao conceito generalizante de "elitismo" e "eurocentrismo". Como reduzir VillaLobos, Guarnieri, Almeida Prado, Gilberto Mendes a estes epítetos? É certo que há diferencias entre os universos. Mas as epistemologias que deveriam assumir essas diferenças, ao meu ver, deveriam estar
} 
estranha relação entre o seu culto nos meios ditos mais esnobes (principais teatros e espaços ditos privilegiados) quando se trata do repertório canônico em contraposição à sua manutenção quase exclusiva às universidades quando se trata do repertório composto atualmente (ou pelo menos nos últimos 50 anos), e nesta ultimo, caso, me limito ao problema brasileiro.

Busco uma delimitação contextual não coagulada: usando o conceito de Sousa Santos como metáfora ${ }^{88}$, posso dizer que o 'sul' repele elaborações estanques; isso, de saída, já coloca o problema epistemológico novamente em evidência. Busco um sentido de afinidade entre o campo delimitado - a música contemporânea - e uma abordagem específica, a estética musical. Neste sentido, como é possível pensar um sentido de continuidade para a música do século XX e XXI? Eis o problema em seu cerne: a explosão estilística dos ismos no início do século XX, em todas as artes, deveria repelir a manutenção de uma única via, ou mesmo o clamor por uma via mais influente. Digo isso em se tomando somente aquilo que entendo pelo tênue fio condutor da arte ocidental, que no século XX, como já procurei identificar, é pulverizado e matizado por diversas fusões em diferentes manifestações.

Se podemos identificar tantas tendências - e aqui sem nem mesmo me refiro à multidiversidade das artes populares - ao fazer específico da arte já no início do século $\mathrm{XX}$, porque determinadas linhas prosperaram e outras foram esquecidas pelo pensamento? É certo que os estudos do cânone, principalmente ligados de forma interdisciplinar às ciências humanas, têm colaborado enormemente para esclarecer e delinear motivos específicos para a manutenção ou pulverização de determinadas

ligadas mais especificamente às questões musicais. Análises muito ideologizadas tem contribuído negativamente para uma separação entre os campos que não se corresponde à realidade amorfa de como a música acontece no Brasil. Por que não se fala de um cinema erudito e um outro popular (cinema de arte é gênero!)? De qualquer forma, à complexidade gerada pelas explicações redutivas, busco a simplicidade que possa gerar o pensamento complexo (e aqui penso no que diz Edgar Morin): para este trabalho basta compreender que, do ponto de vista musical, não me aterei ao universo da canção popular brasileira urbana, ou mesmo à música instrumental popular; nem às manifestações do folclore brasileiro, apesar de admiti-los no mesmo patamar de importância social, histórica e cultural de qualquer manifestação artística clássica. Me atenho exclusivamente ao caminho tomado pela música dentro da tradição específica a que me referi, que opto por chamar música contemporânea ou nova, indistintamente. Penso que as ciências humanas podem contribuir muito positivamente para averiguar essas diferenças de universos musicais dentro de suas epistemologias, desde que não as assuma como profissão de fé. Não à toa, o vínculo da sociologia da música com as manifestações musicais populares tendem, no Brasil, à ser mais estreitos, enquanto os da música de concerto são mais vinculadas ao universo das ciências empíricomatemáticas. Essa associação só é tomada natural no sentido em que a vim apresentando: ela se corresponde com a construção associativa de uma velha idéia de ciência com a música de concerto. $\mathrm{O}$ risco, é a associação mecânica de uma proposta materialista como tendo afinidade apenas com as análises das ciências humanas e com a música popular.

${ }^{88}$ Estudos sobre o que seriam as "epistemologias do sul", organizados por SOUZA SANTOS e MENESES (2010). 
experiências poético-estéticas. No entanto, nos limites que me impus para esta abordagem filosófica, como compreender que, mesmo com a existência de tantas poéticas interessantes da modernidade, determinados postulados de vanguarda tenham se mantido pregnantes até hoje no pensamento musical e das artes de modo geral?

Não há dúvida de que eu poderia, ao buscar estas propostas de realinhamento da estética da música contemporânea, me ater exclusivamente em exemplos que comprovem a multiplicidade da experiência musical dos séculos XX e XXI, usando-os como matriz para um novo empreendimento estético. De certa maneira foi o que procurei empreender em minha dissertação de mestrado, e nas poucas vezes em que no presente trabalho me refiro a ela, o faço para que se verifique uma certa continuidade, tentando evitar, a bem da verdade, uma desagradável autorreferencia contínua.

Mas no sentido dessa continuidade, é certo que na ocasião procuramos, através do campo da estética musical, examinar aqueles renegados do mainstream. Em parte, partimos de uma relação multidisciplinar de base bastante ampla, cuja gama ia dos dados dos estudos culturais (Stuart Hall, Homi K. Bhabha) à filosofia da arte de Heidegger. Neste sentido, este trabalho preliminar pode ser tomado como exemplo de uma tentativa que uma nova estética poderia realizar. Então, primeiro o exemplo particular, agora uma tentativa de uma experiência mais geral, atinente à própria possibilidade da disciplina.

Nos presentes ensaios, tenho buscado, de forma colateral, pensar os sentidos da manutenção de um mainstream da música, a partir de uma demonstração estética que verifica certas pregnâncias e manutenções, do nascimento da estética como disciplina até os dias de hoje. É o caso, agora, de identificar de que forma se imbricam os conteúdos das estéticas e das poéticas a partir do século XX, procurando identificar o mainstream.

Julguei necessário escolher este caminho para a organização do pensamento especialmente por dois motivos: uma reavaliação da estética passa pela reavaliação de como e porque foram tomados determinados conteúdos; as hipóteses sobre a possibilidade de definições sobre a natureza da música e da arte podem dar base para esta reavaliação.

Pensando neste sentido, toda a teleologia que apontei na primeira parte deste trabalho, demonstrando como as relações entre as poéticas e as estéticas musicais se orientaram num sentido cujo finalismo é reivindicado, no século XX (especialmente no pós-guerra), pela autoproclamada "Segunda Escola de Viena", se torna pertinente para 
um olhar crítico e relacional: como, e se de fato ocorre, essa configuração onde os postulados desta escola acabam se mantendo pregnantes em detrimento de outros; quais as razões para essa ocorrência e como ela se desdobra; quais são as relações de distinção e similaridade entre os desdobramentos da vanguarda musical e as vanguardas artísticas; e, por fim, em que sentido os efeitos das poéticas de vanguarda se mantêm e se relacionam, no caso da música, com os questões filosóficas até agora levantadas, tais como o problema da liquidez da música, o desenvolvimento de uma hermenêutica da consistência, a teleologia negativa da retirada do corpo e a vocação metalinguística da arte. Como fundo, claro quero deixar que toda essa empresa visa pensar soluções para o pensar; tirar a estética do limbo colocando-a, ao mesmo tempo como sujeito e objeto, no sentido de buscar nela sua vocação para a contestação, e não para a legitimação.

\section{A construção do mainstream e o vício Boulez}

Pretendo levantar uma questão que me parece paradoxal: as poéticas do século $\mathrm{XX}$, especialmente aquelas ligadas aos compositores que se estabeleceram como referencias obrigatórias para compreender a música moderna, estiveram, de uma maneira ou de outra, ligadas ao ideal de Schönberg e sua "má estética" e "boa doutrina artesanal". A ideia de hermenêutica da consistência, conforme eu a concebi, tem a ver diretamente com essa ênfase dada à doutrina artesanal, com essa tendência à arquitetônica que é, ao meu ver, mais um desdobramento de uma metafísica musical de cunho pitagórico-platônico, substanciada num deslumbramento inicial com o método dodecafônico e ratificada na fetichização matemática que busca "fixar o infinito ${ }^{89}$ ".

Segundo Ricciardi (2013) é certo que, apesar das inúmeras e inegáveis conquistas realizadas pelos descendentes desta premissa, de um ponto de vista mais geral, os frutos que se colhem até hoje são muitas vezes "desastrosos", sendo fácil identificar certa precariedade filosófica nos compositores ligados aos desdobramentos da escola de Schönberg.

Onde está, então, o paradoxo? Chegaremos lá. E veremos que se trata de um encadeamento de paradoxos.

\footnotetext{
${ }^{89}$ Pierre Boulez, no ensaio Alea (1966, p. 55).
} 
Quando se busca examinar a questão do 'novo' no pensamento da vanguarda modernista, vê-se que, no caso da música, essa ênfase na doutrina artesanal encontra um problema: o da perpetuação dos estilos em 'escolas'. A busca do novo radical enfatiza a necessidade urgente de que haja, a cada obra, uma nova proposta poética; obviamente isso não é prerrogativa da música. Está em todas as manifestações artísticas de vanguarda. No entanto essas não podem se estabelecer enquanto canônicas, uma vez que em cada nova obra outra doutrina deve ser estabelecida. Até aqui, nenhuma novidade. No entanto, me pergunto: como então esses compositores, herdeiros do serialismo, se estabeleceram como paladinos da composição do século XX, com suas influências se estendendo até os dias de hoje? A questão não é simples, e pode ser abordada de várias maneiras. Opto por uma resposta consubstanciada a partir da imbricação de duas elaborações: uma de cunho mais filosófico e outra que se apropria de um estudo histórico-sociológico de fôlego, relacionado à Segunda Escola de Viena, realizado por Joseph Auner e publicado no The Cambridge History of TwentiethCentury Music, intitulado Proclaiming the mainstream: Schönberg, Berg, and Webern (2004).

É paradoxal que a escola de Schönberg tenha sido quem, em grande medida, deu origem às vanguardas do novo absoluto, categorial. Paradoxal pois sua perpetuação só foi possível devido a uma coesão estilístico-poética baseada no uso comum de seus adeptos do método dodecafônico, o que, nesse sentido, já os diferenciava de vários compositores do pós-guerra, como Stravinsky, Bartok ou Villa-Lobos, que não estavam associados a um único método de composição em específico. Neste sentido, o que é notável, é que seria talvez mais natural que as ideias vinculadas ao novo postuladas pelas linhas da vanguarda musical que vieram depois estivessem ligadas às poéticas desses compositores mais independentes, cuja pretensão no estabelecimento de uma "escola" do novo não se evidenciavam, e cujo desenvolvimento poético se dava em variadas direções. No entanto, o que ocorreu foi a manutenção da escola de Schönberg como orientadora das vanguardas mais hegemônicas, todas elas associadas ao ideal de consistência do serialismo dodecafônico, e, ao mesmo tempo, ao ideal do novo em cada obra.

Logo na abertura do estudo de Auner, temos uma demonstração contundente de como isso se estabeleceu. Embora a bibliografia consagrada ${ }^{90}$ apresente $o$

\footnotetext{
${ }^{90}$ Não é necessário ir muito longe: os livros A História da Música Ocidental (GROUT, PALISCA, 2001), A Música Moderna (GRIFFITHS, 1998), Fundamentos da Composição Musical e Harmonia
} 
estabelecimento da "Segunda Escola de Viena" quase como um desdobramento natural da tradição, a principal via da música nova, e condutora do desenvolvimento da música até os dias de hoje, o processo de estabelecimento nem é natural, nem desinteressado.

Auner demonstra que Arnold Schönberg, Anton Webern e Alban Berg não se furtaram em proclamar que o método dos 12 tons representou a culminância, a finalidade, de todo o caminho da tradição austrogermânica "e, portanto, por implicação, da música em geral." Todos os três compositores sustentaram que eles próprios representavam a única e verdadeira via, baseando-se em argumentos históricos, nacionais e até mesmo metafísicos para justificar as suas reivindicações.

Em Música Nacional, de 1931, Schönberg traçou sua própria linhagem a partir de Bach e Mozart, passando por Beethoven, Wagner e Brahms, e concluindo: "Atrevome a dar crédito a mim mesmo por ter escrito a verdadeira música nova, que, sendo baseada na tradição, está destinada a tornar-se tradição ${ }^{91 " ~(c f . ~ A U N E R, ~ 2004, ~ p . ~ 228) . ~}$

Neste ponto, devo rememorar o fato de que o discurso de Schönberg representa a manutenção da construção realizada já no século XIX, balizada pela estética do absoluto, conforme demonstrado na primeira parte deste trabalho.

Obviamente, a estratégia de Schönberg se estendeu aos seus discípulos, uma vez que em uma série de palestras de 1932-33, Anton Webern remontou as origens do sistema serial dodecafônico ao canto gregoriano, passado pelos flamengos, traçando um caminho progressivo a partir do colapso do sistema de modos da igreja, o fim da tonalidade com a harmonia cromática de Wagner, insistindo sempre num ponto que se tornou corrente no discurso da vanguarda: a inevitabilidade histórica da necessidade da composição serial. Em suas palavras: "É minha convicção que, desde que a música tem sido grafada, todos os grandes compositores, instintivamente, tiveram isso como meta ${ }^{92 "}$ (ibidem). E Alban Berg, que no ensaio Porque a Música de Schönberg é Tão Difícil de Entender? publicado em 1924 por ocasião da celebração dos 50 anos de seu professor, não só postulou para ele um lugar eminente entre os compositores de sua época como

(SCHÖNBERG, 1986, 2001), são os mais estabelecidos no Brasil, colaborando para um universo estático que confirma as impressões: pouca ou nenhuma ênfase aos compositores latino-americanos, asiáticos ou africanos. Recém adotado em diversos cursos de música do Brasil (técnicos ou superiores), no século XX de Alex Ross (O Resto é Ruído, 2009) a importância da música latino-americana se resume aos dois parágrafos sobre Villa-Lobos e por ter sido inspiração para Darius Milhaud. Mas esse já é um passo adiante, já que nos outros, qualquer referência à música fora dos EUA e da Europa é inexistente ou quase inexistente.

${ }^{91}$ Arnold Schönberg, 'National Music', in Style and Idea: Selected Writings of Arnold Schönberg (ed. Leonard Stein, tr. Leo Black), Berkeley, 1984, p. 174.

${ }^{92}$ Anton Webern, The Path to the New Music (ed. Willi Reich, tr. Leo Black), Vienna, 1975, p. 42. 
conferiu-lhe o status de "clássico". Ele teria assegurado "não só a predominância de sua

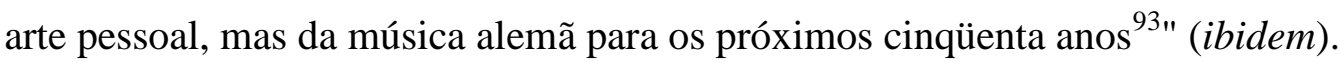

É possível que nestas falas estejam o cerne do problema das vanguardas musicais: a autoproclamação é uma forma de autopropaganda. Essa constatação não diminui o peso inegável das contribuições da escola dodecafônica, mas é certo que a investigação de Auner tem uma importância central: demonstrar que não houve um caminho que possa ser considerado "natural" para o desenvolvimento da música. Sequer um desenvolvimento. Seu estudo demonstra a eficácia da estratégia de Schönberg e seus discípulos na divulgação de suas próprias poéticas, e o modo como eles estabeleceram inúmeras estratégias políticas extra-musicais ${ }^{94}$, das quais se auto-intitular "Segunda Escola de Viena", em referência ao que teria sido a "primeira" (Haydn - Mozart Beethoven), talvez seja o melhor exemplo. Neste caso, como em qualquer caso específico no mundo da arte, o expressivo histórico (a divulgação do pensamento, as estratégias, etc.) se misturam com o aspecto da obra e do modo como as poéticas puderam deixar um legado especificamente musical.

Outra questão é notável e interessa. Uma das estratégias mais comuns residiram na criação de concertos didáticos, voltados à divulgação da música moderna, e em especial da própria música, onde explicações apriorísticas sobre as obras e as teorias sobre as quais se construíam sedimentaram um público, talvez inaugurando essa prática que ficou tão comum, até os dias de hoje, no universo da música contemporânea.

Estes três compositores fizeram um tremendo esforço, em várias direções, para não ficarem marginalizados. Através de seus escritos eles propagandearam os escândalos e se tornaram sinônimo de radicalismo e hipermodernidade, se autoinfligindo uma noção de marginalidade. No entanto, é bastante patente no estudo de Auner, que o modo como eles se autopropagandearam à margem foi uma forma de angariar adeptos. A própria obsessão da escola de Schönberg em se mostrar concatenada à tradição rebate esse destino de hipermodernidade. Ao que parece, temos

\footnotetext{
${ }^{93}$ Alban Berg, 'Why is Schönberg's Music so Difficult to Understand?', in Willi Reich, Alban Berg (tr. Comelius Cardew), New York, 1905, pp. 189-204; pp. 202, 204.

${ }^{94}$ De fato estas estratégias geraram casos curiosos: todos os três compositores estiveram muito ligados a vários intérpretes, regentes proeminentes e instituições importantes, e embora eles ganhassem aos poucos uma relevância por conta destes trabalhos de influência com as diversas instituições, o que é demonstrado pelas longas viagens que eles realizavem, havia também uma característica interessante, refletida na sua suposta posição marginal: aparentemente eles procuraram se manter numa suposta relação de oposição às mesmas instituições pelas quais conseguiam muitas coisas. $\mathrm{O}$ isolamento autoproclamado gerou esta "visão" estereotipada que muitas vezes nos leva ao esquecimento quanto ao considerável número de sucessos que eles obtiveram (ver AUNER, 2004, p. 232).
} 
de fato o estabelecimento de uma dialética na formação do cânone da Segunda Escola de Viena: por um lado a exaustiva autorreferência, reclamando da incompreensão de sua obra e suas ideias ${ }^{95}$, e aqui, vejo como pano de fundo a continuidade de uma metafísica romântica ${ }^{96}$, onde, desta vez, o radicalismo e complexidade do novo seriam o motivo desta incompreensão. Por outro, a proclamação de uma inexorável ligação com a tradição, com a 'linha principal' do desenvolvimento da música. Essa tensão polar entre mainstream e marginalidade não lograria sucesso caso suas ideias não fossem ratificadas no plano filosófico. E neste ponto o papel de Adorno foi fundamental, uma vez que "Theodor Adorno, que é responsável pelas mais influentes considerações sobre a Segunda Escola de Viena, fez do isolamento deles uma medida de autenticidade de sua música" (PADDISON apud AUNER, 2004, p. 230) ${ }^{97}$.

Não me deterei aqui no aprofundamento da especificidade do papel que Adorno desempenhou no estabelecimento e na legitimação da vanguarda musical a partir da experiência da escola vienense. Em primeiro lugar porque essas relações já foram por muitos estudadas e a partir de diversos olhares e epistemologias. Me limito a apontar que, apesar da enorme e reconhecida contribuição de Adorno para a formação de uma sociologia da música, para análise da recém-nascida indústria da cultura (onde, em muitas colocações, foi profético), e mesmo no apontamento de diversas questões que puderam contribuir para uma compreensão mais abrangente das possibilidades da música de seu tempo, é certo que à Filosofia da Música Nova (1958) não cai mal o epíteto de filosofia expressiva, retomando o conceito de Pareyson. Sem dúvida imbuído por uma busca na arte por elementos que pudessem indicar a sua emancipação, e por consequência a emancipação do próprio homem moderno, Adorno também é expressão de um Zeitgeist que relaciona o serialismo dodecafônico com a ideia de resultado

\footnotetext{
95 Schönberg observa: "Eu estou, com meus alunos Berg e Webern, sozinho no mundo. A nova geração de compositores (...) tem feito todos os esforços contra mim e minha música" (AUNER, 2004, p. 229).

96 A dicotomia entre o "comovedor e o sublime" registrada numa carta que Ludwig Tieck escreve para Wackenroder em 1792 (cf. DAHLHAUS, 1999, p.60-63), onde a ideia de incompreensão e ininteligibilidade já aparece delineada e associada ao que é "sublime" ou "elevado", é um exemplo de como determinados ideais podem ser encampados num discurso onde a 'incompreensão' de determinado aspecto da obra musical deve ser tomada como evidencia de sua grandeza; o próximo passo é associar esse fator da incompreensão à 'complexidade', algo que ao meu ver, ocorre no século XX e XXI. Penso que não seria forçar uma interpretação essa associação entre o discurso das vanguardas e certas premissas românticas por excelência, que as vanguardas justamente juraram combater.

${ }^{97}$ Max Paddison, Adorno's Aesthetics of Music, Cambridge, 1993, p. 105.
} 
histórico de um esforço emancipatório com relação à música do passado $^{98}$, doravante sendo o legitimador no campo da filosofia de uma hermenêutica da consistência:

Nenhuma obra poderia demonstrar melhor que as mais breves frases de Schönberg e Webern a densidade e consistência de configurações formais. Sua brevidade deriva precisamente da exigência de uma densidade suprema. Esta proíbe o supérfluo (...) (ADORNO, 2011 [1958], p.39).

O mais notável, dentro da abordagem que venho propondo, é o modo como podemos relacionar essa cadeia de paradoxos, que vai se evidenciar nos desdobramentos da vanguarda a partir da herança da "Segunda Escola de Viena".

No que diz respeito aos aspectos poiéticos, o legado de Arnold Schönberg se deu a partir da invenção de seu sistema serial dodecafônico, tomado como uma das maiores soluções para a música contemporânea do pós-guerra. De fato, o estabelecimento de uma 'via principal' ocorreu a partir de um delicado equilíbrio entre a invenção de uma verdadeira musica nova e um conveniente tratamento da boa e velha tradição. No entanto, tanto os compositores ligados à escola de Viena quanto os seus sucessores, obtiveram sucesso em imprimir uma ideia, especialmente valorizada nos meios acadêmicos, de acesso único à modernidade musical via vanguarda radical ${ }^{99}$. Isso não

\footnotetext{
${ }^{98}$ Este paradoxo, é o cerne de nossa compreensão sobre as colocações de Adorno. O filosofo compreende os dois fenômenos como tentativas de restabelecimento dos "vínculos" perdidos na ruptura das vanguardas, não distinguindo a apropriação do folclore em música artística, das políticas nacionalistas; Neste sentido, interpreta esta busca como uma atitude conservadora, de um nacionalismo que se manifestaria nos países agrários, e de um neoclassicismo nos países desenvolvidos. Assim, erra ao atribuir à escola de Schönberg a vanguarda da música nova, legitimando-a como a saída emancipadora para evolução da música. Essa atribuição sim pôde estar orientada por um eurocentrismo que buscou legitimar esteticamente o caminho de matriz austrogermânica. Do pensamento de Adorno (especialmente em Philosophie der Neuen Musik), se esperava a clarificação do problema dos paradoxos entre os diversos caminhos da música moderna nos primeiros idos dos século XX, mas ele apenas deflagrou-os. Na escola de Schönberg, o progresso. Em Stravinsky, malgrado a reconhecida revolução da Sagração, passa sutilmente a se representar essa "música estabilizada", do Verbindlichkeit (cf. ALMEIDA, 2007), onde "o primitivismo de ontem é a simplicidade de hoje" (ADORNO, 2011 [1958], p.125).

${ }^{99}$ Não se trata apenas da influência de Adorno. A esteta Gisèle Brelet e sua abordagem da temporalidade é bem conhecida justamente pela identificação do ato criador como uma intervenção que prevê a constante dialógica entre matéria e forma, e na excelência da manipulação temporal o seu imperativo estético. A sua idéia magna de que no "ato da criação, é na realidade a obra que determina o artista" cujo autonomia da criação se dá graças ao pensamento sonoro que "procede logicamente segundo leis internas independentemente da personalidade dos diferentes criadores" (BRELET, 1947, p.7) é um claro indício da pregnância de uma autonomia derivada da legalidade interna, das leis formais de uma obra. No caso de Brelet, a temporalidade é a mediadora entre artista e obra, concatenando a consciência temporal do artista à temporalidade da música. Sem dúvida temos aqui uma outra versão desta hemenêutica da consistência, posto que o formalismo autonomista ainda se consubstancia na prerrogativa das leis de organização da temporalidade. Brelet abandona parte dessas concepções que, se de inicio incorpora como ideal o objetivismo de Stravinsky, logo incorpora o ideal das vanguardas seriais e aleatórias, com uma proposta hermenêutica que passa da pura temporalidade para uma expressão temporal do tempo vivido. $\mathrm{O}$ problema da temporalidade de fato passou pela emergência de uma hermenêutica própria, graças às
} 
quer dizer que essa autoconstruída linha de sucessão não tenha o seu valor. Reduzir Schönberg, Webern e Berg ao dodecafonismo e ao uso do método serial seria desprezar não só a sua contribuição enquanto compositores como enquanto teóricos. Eles, sem dúvida, se impõe como artistas para muito além da invenção de seus sistemas artesanais, superando, conforme os diversos analistas ao longo dos anos demonstraram, a lógica do próprio sistema que criaram. Paradoxalmente, foi a partir de seus postulados que a vanguarda musical adotou uma hermenêutica baseada na consistência lógicomatemática, que se tornou hegemônica a partir das correntes sucessoras, gerando não só um idealismo musical-formalista como uma delimitação de campos realizada a partir de um discurso radical e exclusivista, num efeito de que se alastra enquanto manutenção da lógica do sistema: eis o nascimento e o triunfo das teorias apriorísticas em música. Foi o preço a se pagar: a busca pelo novo versus a manutenção da tradição parece ter gerado contradições insolúveis nos postulados de vanguarda. Em 1917 em um de seus importantes tratados ${ }^{100}$, Schönberg, com cuidado, emite a asseveração: "os limites da inteligibilidade não são os limites da coerência", já antecipando um argumento que passou a justificar a abismal distancia entre a consistência matemática das obras seriais posteriores e a sua realidade sonora. A dificuldade para a "percepção das estruturas" criou uma distância até hoje grande com relação à audiência.

No entanto, talvez os desdobramentos teóricos tomados como sendo os mais sérios ${ }^{101}$ circularam em torno da busca pelo controle integral dos parâmetros compositivos, este sim um desdobramento natural do serialismo e, nesse sentido em específico, o discípulo Anton Webern tomou para si o protagonismo: seu tratamento do serialismo procura atingir de tal forma o controle e a determinação dos parâmetros musicais, em um modo radicalmente oposto aos postulados teóricos do sistema tonal, que não é exagero dizer que a vanguarda musical encontra seu sustentáculo no pensamento musical e na obra de Webern, sendo fundamentada a partir do que passou a ser veiculado nos Cursos de Férias de Música Nova (Internationale Ferienkurse für Neue Musik) na cidade de Darmstadt (Alemanha), entre 1946 e 1955. Malgrado ter tido o neoclassicismo musical como orientação no seu primeiro ano, a partir de 1947 se iníciou nos cursos a predominância absoluta dos ideais da escola de Schönberg. Tendo

revolucionárias incursões de compositores no inicio do século XX (o uso bem conhecido do silêncio na obra de Webern é paradigmático) na investigação do uso deste parâmetro.

${ }^{100}$ Em Coherence, Counterpoint, Instrumentation, Instruction in Form, p. 9 (cf. AUNER, 2004, p. 246).

${ }^{101}$ Lembremos que estamos em plena efusão de estilos pelo mundo. Grosso modo, podemos postular a existência de 3 grandes correntes no pós-guerra: o neoclassicismo, o neofolclorismo e os nacionalismos. 
este por guru, Webern como paradigma e Olivier Messiaen (1908-1992) como promotor e incentivador, as orientações poético-estilísticas passaram a ser determinadas com mãos de ferro pelos principais compositores, tais como Luigi Nono (1924-1990), Pierre Boulez (1925-2016), Karlheinz Stockhausen (1928-2007), e, posteriormente, Helmut Lachenmann (*1935) e Brian Ferneybough (*1943). É preciso ainda destacar a presença fundamental de Theodor Adorno. Compositores espalhados pelo mundo foram também caudatários da escola de Darmstadt, como Iannis Xenakis (1922-2001), Milton Babbit (1916-2011), e membros da escola de Nova York, como Morton Feldman (1926-1987) e John Cage (1912-1992). Na América do Sul Mauricio Kagel (Argentina, 1931-2008) e o grupo de compositores brasileiros signatários do Manifesto Música Nova (1963), em especial Gilberto Mendes (1922-2016) e Willy Corrêa de Oliveira (*1938), estão entre os muitos compositores influenciados pelas lições de Darmstadt.

Em todos os sentidos pode-se dizer que não só os parâmetros musicais e compositivos foram radicalizados a partir da formação da vanguarda de Darmstadt. O pensamento musical e os postulados teóricos passaram a um nível tal de discussão e divulgação que o estabelecimento dos ideais representados pelos compositores envolvidos se tornaram rapidamente hegemônicos, principalmente nos ambientes acadêmicos, o que excluiu, sob a alcunha de passadistas, anti-modernos e inimigos do progresso da música, compositores como Stravinsky, Bartok, Alfred Schinitke e VillaLobos (este, execrado pela influência darmstadtiana no Brasil) ${ }^{102}$ dentre muitos outros, especialmente aqueles ligados ao que Adorno chamou de música estabilizada, especialmente os neofolclóricos.

A máxima da consistência e coerência lógico-matemática, que encontrou eco na profissão de fé dos artistas modernos - a de que toda forma é expressiva por si mesma -

\footnotetext{
102 É claro que estes compositores 'cavaram' as fronteiras de seus próprios campos. Stravinsky, um dos mais consagrados compositores da época, se manteve sempre no centro de uma discussão em torno de sua suposta oposição estético-poética com relação a Schönberg e, embora alvo predileto de Boulez e demais expoentes de Darmstadt, não se pode dizer que o debate lhe fez mal aos negócios. Alan Lessem (1982) trata de se opor a esta oposição, demonstrando como, em parte, o que se tem é um falso problema, verificando inclusive similaridades no binômio Schönberg-Stravinsky. No Brasil, uma interessante inversão ocorreu. Quando a influência das doutrinas de Darmstadt se deu no país, ela se concretizou num plano avesso: parte do impulso dos compositores ligados ao Manifesto Música Nova se opunha justamente à hegemonia da música neofolclorista (chamada à época de nacionalista). Como estes compositores (como a maioria dos artistas) estavam ligados à esquerda política, especialmente ao partido comunista, Villa-Lobos passa a ser desprezado especialmente por um fator extra-musical: seu trabalho junto ao governo Vargas. Villa-Lobos se transformaria então em símbolo 'entreguista'. A cadeia de paradoxos não para por aí, uma vez que, ao se oporem ao neofolclorismo estando ao mesmo tempo ligados aos movimentos de esquerda, esse compositores estavam se opondo, por conseqüência, às doutrinas de Jdanov, justamente as que postulavam um programa rígido de arte em torno do nacionalismo e do uso da música folclórica, vindo diretamente da URSS.
} 
pode ser resumida no modo como Webern postula a meta da composição musical: tratase da tentativa de "deduzir tudo de um só pensamento e assim produzir a mais estreita coerência possível: tudo é derivado do tema" (WEBERN apud TERRA, 2000, p. 56).

O paradigma Webern aparece constantemente na expressão "música pósweberiana" para se referir à toda e qualquer manifestação da música pós-serial ${ }^{103}$. Sem dúvida à vanguarda autoproclamada de Damstadt esteve ligados os desdobramentos mais variados e tomados como os mais importantes da música contemporânea, mesmo em escala mundial: música eletrônica/eletroacústica, acusmática, concreta, aleatória, estocástica, realizada a partir da teoria dos conjuntos, entre outras tendências ditas experimentais que se desdobraram em outras inúmeras formas de manifestações em diversos países, especialmente na Europa e Estados Unidos. Mas é certo que seu mais severo e radical divulgador/combatente, Pierre Boulez, se manteve fiel a sua linhagem, e com a sutileza de sempre assevera:

Nós já o dissemos. Nós acreditamos nisso mais do que nunca: Webern continua sendo o limiar da música moderna; todos os compositores que deixaram de sentir e de compreender profundamente a necessidade inelutável de Webern são completamente inúteis (BOULEZ, 1966, p.379) ${ }^{104}$.

Mas duas coisas me motivam a tentar um exame destes problemas. E ambas anunciei no início desta terceira parte: em primeiro lugar, levantar alguns paradoxos que nascem das contradições implícitas da construção do cânone da vanguarda hegemônica da música do século XX e que, em grande parte continua neste início do século XXI. Em segundo lugar realizá-la no modus operandi que acredito para a estética que aqui proponho. Se no método ainda não estamos no fenômeno, o melhor talvez seja testá-lo enquanto se o examina. Assim sendo, busco levantar esses paradoxos de um ponto de vista mais estético do que poético, me interessando menos pelo problema específico da doutrina artesanal e mais em como, e em que medida, eles se estabelecem. Para tanto,

\footnotetext{
${ }^{103}$ Mesmo a aguda percepção de Umberto Eco não escapa desse vício, pelo menos nos idos dos anos 70 (cf. ECO, 1972, p. 153-180).

${ }^{104}$ Ao que parece, os modernistas de toda a parte, mesmo assumindo projetos tão distintos e até mesmo opostos, compartilham de um mesmo espírito engajado-excludente. Mario de Andrade, para o bem ou para o mal sempre avant la lettre, no final dos anos 20 já dizia: "Todo artista brasileiro que no momento atual fizer arte brasileira é um ser eficiente com valor humano. O que fizer arte internacional ou estrangeira, si (sic) não for gênio, é um inútil, um nulo. E é uma reverendíssima besta" (ANDRADE, $1962[1928])$.
} 
uma visão sociológica como a de Auner pôde fornecer dados importantes. Mas como podemos sintetizar estes paradoxos ${ }^{105}$ antes de pensá-los como problemas filosóficos?

Pois bem:

Vimos que os ideais de Schönberg em torno de uma "boa doutrina" artesanal e uma "má estética" pôde gerar alguns resultados concretos na história da música do século XX. O mais evidente se deu no rigorismo teórico-matemático que passa a ser postulado nas obras dos compositores de vanguarda, resultado da ênfase na doutrina artesanal: postulados de teorias a priori para construção de cada obra, divulgadas em larga escala; a ênfase pedagógica a partir das bulas explicativas das teorias, cada vez mais necessárias para a compreensão das complexas estruturas matemáticas reguladoras das obra musicais, que são normalmente apresentadas antes de cada obra; o fetiche das tabelas de simetria e da transposição das teorias das ciências duras para a feitura das obras musicais (música estocástica, teoria dos conjuntos); o postulado do novo radical em cada obra: cada peça musical com sua própria fórmula e método apriorístico.

Se podemos dizer que temos como um dos resultados uma música rica em artesanato mas pobre de mundo ${ }^{106}$, e mundo aqui aparece ligado aos sentidos que apresentei para uma aproximação a uma definição de arte, é certo que temos, curiosamente, algo no sentido contrário: se esses compositores se estabeleceram a partir de uma valorização dos aspecto fabril em detrimento de uma preocupação com aquilo que pode ser veiculado enquanto produção de mundo, ou seja, suas estéticas, é certo que ficaram mais conhecidos e influentes devido à divulgação de seu pensamento sobre os problemas da música do que por suas obras. Em outras palavras, temos que a hermenêutica da consistência, cuja ênfase está na construção lógico-matemática da poética, lega pouco no sentido da poética, e, paradoxalmente, muito (quantitativo) no sentido da construção de uma estética. Isso explica o que eu chamei no título como "vício Boulez".

Atuando como professor de história da música na Universidade de Ribeirão Preto (UNAERP) nos últimos 5 anos, me identifiquei com o artigo "Boulez and

\footnotetext{
${ }^{105}$ Rubens Ricciardi lança em alguns de seus estudos o conceito de Paradoxos Modernistas, que pudemos desenvolver em parte também de minha dissertação. No entanto, o conceito foi desenvolvido mais na direção dos problemas políticos e das poéticas musicais em torno dos conceitos de nacionalismo, neofolclorismo e neoclassicismo. No caso presente, a questão é discutida em torno da vanguarda musical que se tornou sinônimo de vanguarda de Darmstadt, tentando levantar questões mais filosóficas do que poéticas e políticas.

${ }^{106}$ Pode ser ver essas expressões no texto introdutório publicado no programa do $48^{\circ}$ Festival Música Nova "Gilberto Mendes" (2014), escrito por Gilberto Mendes, Rubens Ricciardi e por mim (MENDES, RICCIARDI \& GALON, 2014), que publicarei no apêndice do presente trabalho.
} 
Godard", de Greg Sandow. ${ }^{107}$ Embora escrito sem pretensões acadêmicas e publicado de modo informal, Sandow levanta importantes questões: porque durante tanto tempo, e até hoje, o mundo da música clássica "ao mesmo tempo em que não programa a música de Boulez com muita freqüência, ainda o trata como se sua música fosse grandemente importante?" (SANDOW, 2012, p.1). No artigo, Sandow relata:

\begin{abstract}
Eu me lembro de conversar com um membro de uma faculdade na maior universidade de música do estado, que queria ansiosamente me conhecer porque gostava das minhas ideias. Ele não acha que Boulez, em suas composições, tenha dado quaisquer passos musicais que compositores atuais devessem dar. Mas ainda assim, quando ensinava história da música, ele dava grande atenção a Boulez como um grande e pioneiro compositor radical (ibidem).
\end{abstract}

Devo confessar que, enquanto professor, sempre constatei fenômeno similar. Examinando mais de perto, me parece claro que temos reproduzido o caminho canônico numa mecânica brutal do hábito. Como já expus anteriormente, a bibliografia básica sobre a música do século XX traduzida para o português, especialmente o muito utilizado A Música Moderna de Paul Griffiths (1998), lida de forma teleológica com os fenômenos da música do século XX: de Debussy-Wagner a Boulez-Stockhausen, e depois os compositores estadunidenses, como Cage e Babbit. As inúmeras publicações em livros desses compositores ligados à vanguarda de Darmstadt (especialmente Berio, Boulez e Stockhausen) deram a eles uma dimensão, e por consequência uma dimensão à música de vanguarda, que suas conquistas no plano poético não atingiram: os compositores criticados e excluídos pelas fileiras da vanguarda têm sido descobertos e, paulatinamente, mais executados do que eles em todo mundo. No entanto, a manutenção das estéticas das vanguardas continuam vivas, especialmente no ambiente acadêmico. Minha hipótese é bem simples e já foi apresentada na primeira parte deste ensaio: há uma compatibilidade de naturezas entre a hermenêutica da consistência e a ciência positivista. $\mathrm{O}$ meio acadêmico continuará abraçado à velha vanguarda enquanto postular uma velha ciência.

As explicações para a ocorrência deste paradoxo (onde quem postula a supremacia do sistema artesanal (poética) só consegue legitimação a partir da

\footnotetext{
107 Publicado e traduzido em 2012 por Leonardo T. Oliveira em: http://euterpe.blog.br/historia-damusica/a-crise-da-musica-classica-por-greg-sandow. Acessado em 09/01/2016.
} 
estética $)^{108}$ ao meu ver estão na sua origem: na escola de Viena, a hipermodernidade das intenções de ruptura total com a tradição tonal dada no serialismo é não consubstancial às posições políticas conservadoras, bem como a uma tentativa de justificar a própria ruptura com o passado com a ideia de "necessidade histórica" e conexão com a tradição. Isso se verificará mais tarde, já em Darmstadt, como uma forma basilar de se relacionar com a tradição: basicamente criando uma "tradição do novo", o que também é paradoxal. Por isso o novo "absoluto" só pode ocorrer via desenvolvimento de um fío condutor que une as poéticas (outro paradoxo?): justamente a serialização, que aos poucos atinge tal nível de totalização (e Boulez é um dos responsáveis) que explode em seu contrário, o aleatorismo e a indeterminação, também filhos da vanguarda.

É curioso notar a extensão desse paradoxo principal ocorrendo às avessas, na trincheira oposta: Igor Stravinsky, saudado justamente pelo seu objetivismo e construtivismo musicais, tendo sido o mais influente compositor do ponto de vista do alcance de suas obras em múltiplos diálogos com a cultura contemporânea, sendo influência para Villa-Lobos, dentre muitos outros, e adepto de uma fecunda poliestílistica, não se furta a demonstrar a sua boa estética justamente em sua Poética (!) Musical em 6 lições (1996 [1942]), apresentando a ideia de música enquanto fenômeno especulativo:

\footnotetext{
Pois o fenômeno da música não é outra coisa senão um fenômeno especulativo. (...) Os elementos a que essa especulação necessariamente diz respeito são o som e o tempo. A música é inconcebível quando isolada desses elementos (STRAVINSKY, 1996 [1942], p.35).

(...) Julgar, questionar e críticar o princípio da vontade especulativa que está na origem de toda criação é, assim, definitivamente inútil. Em seu estado puro, música é especulação livre (ibidem, p.52).
}

Aqui, não estaríamos justamente diante de uma tentativa de compreensão da música a partir de sua vocação à liquidez? E a rigidez da escola de Darmstadt, cujas teorias apriorísticas cristalizam de antemão muitas possibilidades formativas, não seria a culminância da ausência do corpo? Não por acaso, o próprio Stravinsky (como Chostakovith, Villa-Lobos e outros não contemplados pela vanguarda) traz novamente à cena a importância do impulso visceral nas novas tendências do ritmo e na associação com as artes da dança e com as culturas populares, mesmo o jazz.

\footnotetext{
${ }^{108} \mathrm{E}$, do ponto de vista que venho adotando, a estética deve justamente abandonar esta sua vocação à hegemonia e à legitimação, na verdade, já Pareyson, como nunca é demais lembrar, aponta que não é papel da estética a invenção de programas de arte.
} 
Falar em 'boa' ou 'má' estética é muito mais uma forma de me referir ao objeto usando seus próprios termos (não sem alguma ironia) do que assumir um juízo de valor rígido. Obviamente, na tentativa de definição de arte que tracei, a condição da arte passa por uma noção de pluralidade que inclui a técnica, a objetivação da possibilidade projetual e a exposição de um mundo-obra residente na transformação simbólica das meras coisas, e para isso, um pensamento, uma estética. Em outras palavras, do mesmo modo que uma arte sem artesanato resultaria pobre de mundo, na verdade numa nãoarte, do ponto de vista que venho adotando, uma arte sem estética também. No caso a vanguarda musical não legou uma arte sem estética, mesmo porque isso resultaria também na não-arte. No entanto, essa "má estética" seria justamente a prática de construção de um campo teórico normativo, regulador e legitimador do corpus de praxistico é poiético. Tomando Pareyson, não estaríamos nem mais no campo da estética, mas em algo próximo de uma epistemologia crítico-teórico-política.

Por reconhecer a atividade do artista-esteta, do compositor-esteta (seria o paradoxo dos paradoxos pensar o contrário), e por assumir a impossibilidade da neutralidade em termos de ideologia, tomo também como legítimas as noções estéticas da vanguarda. Mais do que isso, suas contribuições para determinados campos epistemológicos, como a ciência analítica da música por exemplo, são sem par. No entanto, tenho procurado refazer este caminho para tentar um pensamento mais inclusivo.

É estranho que Adorno tenha demorado tanto para perceber que, após anos de experimentalismo vaguardista, a radicalidade desse pensamento musical redundou num idealismo do novo; e a ideia de que a "cultura contemporânea a tudo confere um ar de semelhança" (ADORNO, 2007 [1947], p. 7) pode não mais ser aplicada unicamente ao fenômeno da industria da cultura.

\section{As perspectivas da música no ambiente da morte da arte}

É impossível, ainda hoje, qualquer análise de cunho histórico-filosófico sobre a arte que ao menos não esbarre no problema de sua morte. Embora a ideia de "morte da arte" se mantenha em grande parte associada ao problema das artes visuais, a ideia de morte da arte tem permeado em maior ou menor grau as manifestações do pensamento sobre a arte moderna, pelo menos as que não estejam diretamente ligadas às produções da indústria da cultura ou às manifestações das grandes mídias hegemônicas, e, mesmo 
assim, não é difícil encontrar elaborações estéticas que vejam no advento da indústria da cultura a verdadeira morte da arte.

Enquanto me encaminho para as conclusões finais deste percurso, buscarei recuperar alguns aspectos já desenvolvidos neste ensaio, aqueles associados às possibilidades de definição de arte que vim delineando, para exemplificar a sua aplicação e procurar compreender a partir dessas óticas determinados problemas. Desta forma espero que a análise anterior sirva como base para que se possa verificar as diversas nuances que diferem a situação geral da música contemporânea (o que inclui as suas estéticas) da dimensão que os mesmos problemas têm tomado nas outras artes e no pensamento sobre elas. Neste sentido, como demonstra Umberto Eco, a ideia de morte da arte é tema fundamental por onde passam as possibilidades de uma definição:

\begin{abstract}
Até há pouco tempo, o tema filosófico da "morte da arte" parecia ter ficado confinado no âmbito dos sistemas estéticos do idealismo e, como tal, adstrito a uma situação cultural específica. Assim, falar em "morte da arte" parecia implicar um quadro sistemático bem preciso, uma filosofia do espírito bem definida nos seus vários momentos: pois se a arte como forma espiritual morre, deverá surgir algo diferente que o sistema preveja como momento sucessivo, estádio de integração mais alto. Mas de há um tempo para cá, a ideia de uma "morte da arte" volta com certa insistência fora do quadro idealista, em escritos críticos de vária ordem, sempre que se pretende discutir a situação e o destino da arte contemporânea. Por outras palavras, a evolução das poéticas a partir do romantismo tardio denuncia uma modificação sensível do conceito de arte no âmbito da cultura moderna, e leva os críticos ou historiadores das poéticas a perguntarem-se até que ponto esta modificação é radical; e em que medida se impõe uma revisão dos conceitos às próprias estéticas filosóficas (ECO, 1972, p.123).
\end{abstract}

Com o advento do pensamento pós-moderno, com todos os logros e malogros que ele pode estar legando para o pensamento geral sobre a arte, ou seja, para as possibilidades de pensar esteticamente, há uma tendência, que como vimos é influenciada diretamente pelas abordagens das ciências humanas, em reavaliar a noção de arte e apresentá-la como evento, ou de não mais considerar a obra de arte dentre os objetos diferenciados, que deveriam ser analisados em sua especificidade. Tal tendência caminha na direção de um pensamento que considera a obra de arte como algo produzido como qualquer coisa produzida: vemos assim ser negada toda uma metafísica da arte, mas, ao mesmo tempo, há toda uma consideração redutiva de algo que, balizado por grandes filósofos, não deveria ser desprezado, senão estudado em pormenores, justamente a sua especificidade dada na possibilidade da sua singularidade. 
Neste ponto, podemos pensar que um dos motivadores naturais para essa desconfiança - não só em torno da arte mas também de qualquer pensamento especulativo ou estético, cada vez mais considerado árido, reside nos rumos que a arte e as consequentes compreensões em torno dela tomaram a partir do século XX. E isso pode ser balizado a partir da noção de "morte da arte". Afinal, se a arte é mais uma coisa dentre as meras coisas, é porque ela não é nada de específico. Então, ela não faria sentido enquanto linguagem diferenciada, uma vez que, de certa forma, muitas das grandes artes não servem para nada. Ela seria nada. Ou, com a morte da ideia de arte, pode-se ver morta ela própria quando reduzida a uma produção analisável de forma mais clara pela sua pregnância cultural ou pelo seu viés científico, e não pela suposição da existência de uma característica de formar por formar, de puro êxito, não desvanecente numa função de apetrecho.

Tudo isso implica não só numa mudança de paradigma que pode gerar diversas possibilidades de se pensar a arte, mas em questões mais profundas que afetam não só o fazer artístico mas a possibilidade de uma disciplina filosófica que pense este fazer em sua especificidade. No caso da música, temos ainda o problema de que sua excelência de arte do tempo, arte liquida, lhe confere um destino diferenciado, em essência, dos efeitos provocados pela ideia de morte; pelo menos no que diz respeito ao desenvolvimento desta ideia em outras artes. Assim, é notável observar que a morte da música tem cores mais sutis, mas não menos evidentes, e se apresenta de forma diversa do que ocorre em outras artes.

A argumentação sobre a morte da arte possui uma longa história. Desde que estabelecidas as bases para o pensamento sobre a arte ocidental, as ideias sobre seu fim, compreendido enquanto esgotamento técnico ou exaustão das possibilidades estéticopoéticas, são mais ou menos abundantes. Assim sendo, parece óbvio que o problema da exaustão ou esgotamento de artes baseadas em determinados paradigmas é parte do próprio encadeamento histórico enquanto devir de acontecimentos diacrônicos, cujas emanações não são exatas e quantificáveis, mas ainda sim analisáveis enquanto possibilidade de compreensão de um certo Zeitgeist. Em outras palavras, a morte da arte, em não sendo uma ideia de primazia moderna ou contemporânea, pode muito bem ser uma essência de cunho dialético, residente na arte quando esta atinge a vocação para a sua plenitude técnico-expressiva, pressupondo imediatamente a sua 'morte'.

Se tomarmos a mitologia em torno do nascimento da arte e da música a propósito de Hermes, temos que, para que a música nasça, deve ocorrer a morte, a 
imolação da vítima, o tormento e o sangue. É notável que o caráter hermético apareça justamente sob o signo do tormento e da morte, necessários para o devir da arte.

Dino Formaggio identifica Hermes como o inventor da linguagem. É ele quem

traz o sentido de mediação, necessária para que a linguagem seja linguagem:

Hermes faz a mediação da morte na vida, da ausência na presença significativa do completamento e da totalização do sentido na obra, que assim se torna arte; e faz a mediação da vida na morte, da viagem nocturna aos infernos, de uma estadia no inferno, da luta desesperada contra morrer, contra o morrer do sentido das coisas, contra tudo o que é alheio, contra o nada e contra a passagem: a passagem que se encontra nas metamorfoses, da argila que se transforma em obra, do mármore de Paros que se torna Atenas (...) FORMAGGIO, 1976, p.25).

É justamente Formaggio o filósofo que identifica a arte sob o índice do nada.

Esse 'nada' tornado poética é o paradoxo maior da modernidade. Já não é o nada hegeliano do morrer para nascer de novo segundo uma absorção do velho na morte. É o nada da vacuidade, da nulificação, dadas na individuação.

A violência e o bramido primordial do Caos e do Nada canalizam-se nos números e nas formas, fazem-se dança e música nas fronteiras do princípio apolíneo de individuação. Esta é a nova via do conhecimento: quem viu, viu a horrível verdade, viu o nada absurdo da existência e cai, desfalecido, no abismo do esquecimento. É necessário, então, domesticar o terrível, anular o nada absurdo, transformar tudo isso pela força da arte e redimi-lo no sublime. O conhecimento vela-se misteriosamente para sair do êxtase mortal e passa, depois, a acção, a praxis libertadora: é o nascimento da arte. Uma arte que, primeiro e acima da ciência e mais do que a moral, se apresenta "como atividade metafísica própria do homem". Das pedras pobres e inertes sob o sol do Olimpo, os deuses da Grécia. Do pessimismo doloroso do niilismo, do nada fulgurante do fundo da existência, a ressurreição libertadora da arte através da loucura dionisíaca, o tornar-se outro para se reconhecer, o perderse para se reencontrar, na obra acabada (ibidem, p.26).

É esse nada primordial, canalizado na modernidade, manifesto em suas estruturas e pregnante como projeto:

O Nada que se inscreve na contemporaneidade não é o "nada hegeliano". "O nada sob cujo índice a arte veio a colocar-se não é, precisamente enquanto índice metodológico, um nada lógico ou dialéctico, um nada integrado numa mediação conciliadora, mas o nada do salto qualitativo kierkegaardiano, um nada que diz respeito à diferença e à repetição: e "a diferença e a repetição tomaram o lugar do idêntico e do negativo, da identidade e da contradição" (G. Deleuze). Sabemos que isso aconteceu realmente após a falência da representação (isto é, onde o signo representativo e mantém unido ao ser) no pensamento moderno. A substância que se torna sujeito é também a morte do sujeito como identidade. A partir daqui, o nada começa o seu trabalho, a sua função, A arte encontra-o dentro de si, em cada uma das suas fibras (FORMAGGIO, 1976, p.59). 
Embora não seja novidade que todo movimento artístico ou mesmo histórico traga em si, pelo menos em sua formulação abstrata, o germe de sua própria destruição - e aqui poderíamos citar uma série de teorias, especialmente aquelas mais materialistas que levantam o problema da modernidade - parece-me claro que, discutir as bases que fundamentam a ideia de morte da arte e indicam as diferenças entre a sua compreensão enquanto uma essência que permeia todo o pensamento sobre arte em todos os tempos e a sua formulação específica enquanto problema filosófico essencial para a compreensão dos paradigmas da arte contemporânea, é procurar uma base para que se fundamente uma própria noção estética concatenada com o espírito contemporâneo, atualizando assim as possibilidades de se pensar filosoficamente sobre a arte já ocorrendo certo distanciamento do frenesi vanguardista. Afinal, não seria o desafio magno de uma estética atual justamente a diferenciação entre aquilo que é historicamente determinado e aquilo que seria revelativo da própria coisa? Ou, para dizer de outra forma, todas as emanações são históricas e partem da essência da arte, no entanto cada período elege aquilo que deve vir à lume na produção poética.

Se como aventei anteriormente, uma definição de arte pode ser postulada em torno da ideia de que expressão, conhecimento e fabricação podem se imbricar enquanto conceitos mais específicos, como desocultação, formatividade e corporalidade, é certo que esta proposta definitória deve ser examinada ainda sob a possibilidade da morte da arte, ou da não existência da arte e, consequentemente de seu pensamento.

É notável que a cadeia de paradoxos que constituem a modernidade pode se revelar na ideia de que a morte da arte, que consigo traria a morte do pensamento sobre arte (ou é resultado dele?) possa ter surgido sob o índice de uma arte que é só pensamento, só conceito.

É preciso assumir, de saída, que aparentemente todas as emanações localizadas historicamente nos movimentos artísticos trazem em si as pistas para investigarmos o que é a arte; algo difícil (será impossível?), mas cujo processo e exercício de pensar aprofundam os caminhos para investigações cada vez mais importantes para a compreensão geral dos problemas da arte; para nosso século, ainda a pergunta: a arte é uma mera coisa? Ou é algo de específico. Se é, o que a torna ao algo fora do mundo das meras coisas? A partir do exame filosófico que já realizei, pretendo, com relação a morte da arte, chegar a iluminar mais alguns aspectos. 
A ideia de morte da arte, embora antiga, alcança sua projeção tanto nas estéticas quanto nas poéticas no século $\mathrm{XX}$, e tem sido analisada sob diversos prismas especialmente nas estéticas das artes plásticas. A radicalidade da argumentação, das rupturas e do alcance das ideias vinculadas ao desenvolvimento de uma arte moderna levou as artes plásticas a tal extremo de experimentalismo (aqui, no sentido literal de experimentar, e não enquanto conceito mais acabado em seu sentido poético) que fica difícil a transposição dos problemas da estética desta arte para os de outra. Difícil não quer dizer desnecessário, principalmente porque na comparação com outros fenômenos de outras artes, poderemos chegar mais perto do que seria próprio da música.

Quando pensamos o problema da música, temos que uma ideia de "morte" é expressa de forma mais sutil enquanto krisis: seja enquanto problema de comunicabilidade, seja enquanto esgotamento e exaustão dos meios técnicos tradicionais, como também pela ausência de fôlego junto aos não iniciados face ao desenvolvimento próspero das linhas de produção em massa da indústria da cultura. No entanto, não seria exagero imaginar que a crise deflagrada na passagem para o século XX é a mesma que está imanente em toda a modernidade: as rupturas deflagradas desde então não cessaram e as novas linguagens parecem ter nascido coaguladas sob o signo do novo absoluto. Seria esta a crise da subjetividade auto-proclamada, a da centralidade do sujeito, tão propalada por Hannah Arendt ${ }^{109}$ ou Ernst Bloch? Enfim, talvez pudéssemos ler a modernidade da arte como a transformação da crise em poética. Ou do nada em poética.

Entre as coisas que me interessam especificamente na questão da 'morte', está pensar em que medida ela pode ser resultado de um processo, na arte de modo geral e na música em especial, que leva em conta 1) a vocação da arte à assunção de um processo metalinguístico; 2) a vocação da música à liquidez. Além disso, pensar de que forma esses processos podem assumir uma formulação associável ao problema da obra: 1) em que medida a definição que tentei buscar recupera sentidos perdidos; 2) em que medida essa definição promove uma necessidade de realinhamento epistemológico para a estética da música.

A radicalidade da experiência artística a partir do século $\mathrm{XX}$, quando à explosão de 'ismos' seguiu-se uma busca radical pelo novo absoluto, deflagrou uma situação limite. É certo que qualquer leitura, mesmo superficial, das histórias das artes,

${ }^{109}$ H. Arendt, La condition de l'homme moderne, Paris: Calmann-Lévy, 1961, p. 286. 
pode indicar que muitas vezes essa situação limite se concretizou. Especialmente no caso do surgimento de poéticas experimentais que, mesmo sem romper com o passado, buscaram a superação de uma situação de exaustão já estabelecida. Se pensarmos no caso da música, quase sempre o problema se resume a esse novo que surge de um processo de exaustão.

Jacques Stehman (1979 [1964], p.287) finaliza o seu História da Música Européia com uma seção curiosa dos desmentidos da história. São quatro citações, cada uma de um século (do XVII ao XX) que resumem este problema. O Conego Artusi (1545-1613) não poupa o compositor Monteverdi (1567-1643) por procurar "efeitos inéditos", tornando a "música moderna desagradável ao ouvido", chamando-o "traficante de novidades". No século XVIII Rousseau insinua que o "senhor Rameau" tornou seus acompanhamentos confusos, provocando dificuldade ao ouvido devido ao "alarido contínuo dos diversos instrumentos". Em 1810 Beethoven também não escapa ao julgamento sumário de um crítico francês que considera o sucesso de suas sinfonias como algo "perigoso para a arte musical". É certo que a crítica à modernidade de Beethoven não se resumia às "bárbaras dissonâncias" onde apenas se consegue "rasgar ruidosamente os ouvidos sem falar ao coração", mas atina diretamente à problemas ideológicos extramusicais. Em 1902, a crítica Camille Bellaigue aponta que não "existe ninguém melhor qualificado do que o senhor Debussy para presidir à decomposição da nossa arte (...) uma tal arte é malsã e nociva, os germes que a contém não são os de vida e de progresso, mas sim de decadência e de morte". Poderíamos citar muitos exemplos ainda dessa reprodução ad nauseum da disputa entre antigos e modernos. No Brasil, o crítico Oscar Guanabarino se tornou um dos maiores desmentidos da história devido a uma abordagem destrutiva e distorcida do modernista Heitor Villa-Lobos.

Embora o problema possa ser abordado de múltiplas formas, como no exame do contexto social das querelles, nos problemas biográficos envolvidos, e até mesmo numa relação que procure investigar o papel da crítica nas artes, me parece razoável um exame estético que tome "novo" como objeto. E este novo tem fatalmente estado relacionado com a ideia de fealdade.

De fato vemos que a questão da arte contemporânea se relaciona não só ao tipo de compreensão do novo quanto ao aspecto da ausência de sentido e da deflagração da fealdade. No caso da música, me arrisco a dizer que devido ao seu caráter amalgamante e tendente à liquidez, bem como pela sua polissemia, muitas vezes lida como ausente de sentido, de linguagem não verbal e no tempo, ela já tenha nascido moderna e 
experimental. No entanto, a questão da fealdade talvez se faça presente - e ao que parece sempre foi central - na questão do novo, e esse divórcio entre a arte e a beleza na música estaria sob os auspícios da vanguarda e seu suposto casamento com o "feio".

Talvez seja então necessário nos colocarmos a pergunta: seria o caso das vanguardas musicais ligadas às linhas de Darmstadt, residentes desde sempre numa contradição que a mantêm hegemônica na avaliação crítica e acadêmica, mas afastada inexoravelmente do público, se tornarem também "desmentidos da história"? Penso que não. Pelo menos no caso da música. E é por isso que o presente estudo busca uma definição alternativa para uma outra estética da música.

Neste sentido, é certo que, ao menos no caso da música, foram amplamente divulgadas as falas que, desde os ditos da Segunda Escola de Viena, e olhadas retroativamente desde hoje, deflagram aqueles paradoxos: os 100 anos de supremacia da música austrogermânica (que em alguma medida me parecem se cumprir) versus a ideia de compreensão e valorização "só daqui há muitos anos", como foi recorrente nas falas de Darmstadt.

Penso que novamente é possível identificar o componente romântico que a vanguarda jurou negar. Esse reconhecimento só para iniciados, esse componente da incompreensão e reconhecimento público num possível post mortem, deflagram novamente as estratégias de manutenção que se tornaram correntes, e que, pelo viés de uma hermenêutica da consistência fechou um ciclo de complexidades para que se tornasse cada vez mais difícil dizer: "o rei está nu"!

É nesse sentido que hoje talvez possamos olhar para a adesão ao novo, recorrente na modernidade: dentro de um contexto contraditório onde a dificuldade em se desatrelar música contemporânea ou nova dos ideais da vanguarda, se faz presente no ambiente acadêmico, tendo no entanto malogrado totalmente com relação ao público e à participação em concertos fora de festivais ou das universidades.

Ao que parece, esta situação não ocorre no universo das artes plásticas. Um dos maiores críticos brasileiros da vanguarda (ele mesmo tendo sido um de seus pioneiros), o poeta Ferreira Gullar discorre em seus ensaios longamente sobre como a ideia de arte enquanto 'choque' pode render um ciclo financeiramente virtuoso para os artistas conceituais da moda nas bienais. O choque do novo absoluto, a redução da arte ao artista (a própria consubstanciação da centralidade do sujeito), a arte enquanto evento e experiência, puderam trazer um componente de publicidade importante, que faz com que a vanguarda se mantenha viva nas artes plásticas também fora da academia. 
Se neste sentido o destino da música na contemporaneidade é diferente do das artes plásticas (ouso dizer que da poesia e do cinema também), ainda há algo de semelhante que nos chega por vias diferentes: se na música notamos, já há algum tempo, uma aparência de coagulação, especialmente quando nos encontramos nos festivais esperando ouvir uma prévia de como o compositor soluciona com alguma teoria apriorística o problema de sua obra composicional; quando ouvimos quase sempre sonoridades parecidas oriundas da exploração das técnicas estendidas dos instrumentos, dos adensamentos texturais, dos instrumentos preparados, enfim, de toda um universo sonoro que se repete na tentativa sistemática da não-alusão ao sistema tonal, talvez seja o caso de percebermos que, o novo radical gerou o seu contrário.

A tentativa de ruptura total, dada tanto na radicalização do controle e da determinação na obra, como, no extremo oposto, no aleatorismo e na total indeterminação na obra (Cage pretendeu romper com a ideia de obra postulando a ideia de processo) estancou a música numa repetitividade sistemática da não-alusão ao sistema tonal, promovendo justamente uma dependência dele por oposição: uma espécie de 'ênfase por ausência'.

A busca pelo novo parece ter legado, mesmo aos opostos, um "ar de semelhança", quando a música é produto de um tratamento científico. Neste sentido, há algo de similar entre os produtos e processos da vanguarda musical hegemônica e os mecanismos de tratamento dos produtos da indústria da cultura.

Por outro viés e com outros resultados, as artes plásticas se engendraram na mesma superestrutura que gera celebridades e eventos tão indistintamente quanto obras. A arte conceitual flerta abertamente com a indústria da cultura, e, aqui, não vai uma crítica. Antes, uma importante constatação: o de que a essência paradoxal da modernidade se externa em todos os âmbitos, até mesmo no político; uma vez que as vanguardas puderam estar inicialmente voltadas ao pensamento da esquerda e se aproximaram dos fenômenos da industria e de um pensamento de direita:

Anti-moralismo, é certo, mas (...) bem distante da vigorosa socialidade comunicativa da arte. Isto explica (...) a fácil deslocação (...) segundo um fenómeno que, frequentemente, se repete em certas vanguardas, de uma pseudo extrema-esquerda inicial para o abraço final da direita conservadora (FORMAGGIO, 1976, p.32).

Com base na analogia entre ciência e tecnologia, o "modernismo" tacitamente supunha que a arte era progressista, e portanto o estilo de hoje era superior ao de ontem. Era, por definiçao, a arte da avant-garde, termo que entrou no vocabulário 
crítico na década de 1880 , isto é, de minorias que em teoria esperavam um dia conquistar a maioria, mas na pratica estavam satisfeitas por não o terem feito ainda (HOBSBAWN, 2009, p.497).

Como podemos pensar, do ponto de vista estético, este estado de coisas e o modo como se pôde até eles chegar? Recuperemos pois algumas questões.

No Brasil, especialmente, é difícil prever qual seria o destino das manifestações contemporâneas da música de concerto não fosse a possibilidade de sua inserção nas universidades. No entanto a música de hoje nas universidades continua majoritariamente sob o signo da vanguarda ou cede, despudoradamente, ao sabor da indústria.

No entanto, a formulação básica sobre a morte da arte não se veicula de forma tão radical na música por um simples fator: a sua especificidade técnica parece ser mais profunda do que a da pintura, ou da escultura. Explica-se: para escrever um poema dadaísta, bastam letras aleatórias coladas num papel. Não há exigência de uma técnica especifica. Basta o conceito abstrato. $\mathrm{O}$ mesmo para uma pintura abstrato ou readymade. Mesmo para as manifestações musicais mais radicais, raramente se pode prescindir de um mínimo conhecimento técnico de um instrumento, ou de noções básicas de articulação humana em um ambiente de invenção musical. Mesmo que, engenheiros ou matemáticos não-músicos possam criar obras articulando-se num ambiente onde os processos abstratos quantificáveis possam se tornar uma obra musical, ou mesmo um processo musical, algum conhecimento técnico prévio diretamente relacionado às especificidades da música são necessários.

Tendo isso em vista, vemos que a aquilo que tradicionalmente pôde tornar a música a mais radical das artes - arte do tempo, por excelência - não permitiu, de certa forma, que ela acompanhasse naturalmente o caminho das artes plasticas num nível de radicalização que pusesse em questão a própria noção de arte, indo em direção da total autoaniquilação, não só da noção de arte quanto da própria obra.

Assim sendo, aqui, mais do que buscar uma hermenêutica necessária nesta etapa para que possamos avançar numa reflexão conceitual sobre o próprio papel da estética musical e como ela poderia se relacionar com as obras no século atual, é preciso pensarmos o problema no modo como ele se dá: através de uma crise de linguagem, pouco discutida no âmbito da música, e já bastante discutida no âmbito de outras estéticas. Isso é o mesmo que assumir que uma filosofia nova para a música de hoje precisaria refletir necessariamente sobre pontos que, já abordados por estéticas e 
filosofias de outras artes, não chegaram com real impacto sobre o pensamento sobre música. E isso também tem suas razões, como já esboçamos anteriormente.

A ideia de que a música está exaurida, como já dissemos, é antiga. Rupturas são parte do processo dialético possível de se ver nos movimento históricos e sociais consequentemente nos artisticos - e funcionam como costuras e não exatamente como rompimentos, como pode parecer à primeira vista. Normalmente o que a história oficial chama de "ruptura" é na verdade a canalização de forças aparentemente contrárias concentradas em momentos específicos, e que podem ser compreendidas enquanto exaustão de velhas formas em contato com as potencialidades das novas. A situação legada pelos artistas a partir de 1900, e que em parte já continha as sementes do que, no plano conceitual, hoje aí está, parece ser pródiga de uma exaustão que ocorre sob o índice do nada, o que gerou um sem números de paradoxos que pode nos levar a pensar se a essência das manifestaçõs artisticas do século XX e XXI não seria a sua imanencia em uma situação paradoxal.

Passados quase 120 anos desde que as manifestações artísticas mais radicais começaram a se estabelecer, sequer temos certeza sobre como abordar os problemas das artes, e nunca foi tão dificil reconhecer a sua existência. Para que eu possa lançar as bases para um pensamento geral sobre as possibilidades para uma nova estética da música, será preciso primeiro localizar o problema das artes em geral na situação hodierna, a partir daquilo que se tem enquanto pensamento de outras filosofias da arte, mais desenvolvidas ou mais antigas do que a música, para então localizarmos o problema da música procurando similaridades e conflitos, diferenças e igualdades, no que diz respeito a crise de linguagem que já temos propalado, e ao problema daquilo que parece exaurido.

Para tanto, pensar o conceito de "morte da arte", para que, em vista da situação atual vejamos em que as reflexões gerais se aplicam ao problema da música, deixará mais claro o recorte, além de possuir a vantagem de uma análise que aos poucos vai desvelando aquilo que é proprio da arte, e aquilo que é próprio da música; consequentemente: aquilo que é próprio de uma filosofia da música.

\section{A arte, a obra, e o mundo das coisas sob o índice do nada, da morte e da vontade de aniquilação: $o$ i-mundo da arte}

O filósofo Jean-François Mattéi não poderia ter sido mais contundente em sua abordagem sobre a arte moderna: 
O "sujeito", esse não-lugar e essa não-coisa que não participa mais do mundo (...) se reduzirá por sua vez a um simples ponto, o ponto de vista do artista que pode, no limite, prescindir do mundo (...). Não é pois o desaparecimento do sujeito (...) que se encontra aqui em causa, e sim o seu triunfo, a arte se identificando inteiramente com a subjetividade do artista no esquecimento comum do homem e do mundo. E "a barbárie de uma mundialização cega", contra a qual a arte já não pode erguer suas defesas, é na realidade a barbárie de uma subjetivação cega desde que o sujeito, entregue a si mesmo, já não faz mundo, mas i-mundo (MATTÉI, 2001, p.31).

Mattéi, contraria certo senso estético que associa a desagregação da noção de arte e de obra a com o gradual desaparecimento do sujeito na obra: o rosto do homem se desvaneceu, na modernidade, em abstrações, com a perda da "realidade" e da figuratividade na pintura, até o seu completo desaparecimento na obra de arte.

Essa seria uma bela metáfora para a perda do humano na arte, em conformidade com a constatação de Ortega y Gasset ainda nos anos 20. Segundo apontava este, a desumanização da arte moderna seria desrealização, no sentido de perda do real na arte. O que se teria então é o desaparecimento do homem na arte, até a chegada ao nada, a nulificação do sujeito, ou a perda do mundo do sujeito, e enfim a desumanização da arte (cf. ORTEGA Y GASSET, 2008 [1925]).

Mas o que talvez Ortega y Gasset não poderia ter previsto, é que esta perda do real não se tratava da perda do sujeito, mas justamente da tendência à centralização do sujeito até que este substituísse obra, declarando a sua inutilidade. Neste sentido, olhado de hoje, o seu postulado se tornaria paradoxal, principalmente se ainda visto por esse outro ângulo: a desumanização da arte teria se dado justamente via exacerbação do humano, transformado em sujeito; a desrealização ocorreria, paradoxalmente, via perda da possibilidade de transformação simbólica do mundo e da capacidade metafórica da arte. Em outras palavras: a desrealização na verdade ocorre por excesso de realidade, a ponto de a arte prescindir de sua objetivação simbólica e metafórica no mundo das coisas, sendo declarada nula, inútil, uma vez que é tão real quanto o real, portanto, mera coisa.

O real da obra, que sempre fora um real simbólico, e do ponto de vista que adotei, um real dado no desocultar, desvelado na linguagem que é um dizer diferente, um logos específico (e não um problema determinado de um programa de arte, como no realismo ou no hiperrealismo), agora se perde com a perda da obra. Tanto Mattéi quanto Ferreira Gullar propõem um caminho para que se compreenda esse processo de nulificação, esse caminho da obra para a não-obra. 
O percurso para a laicização da arte, submetida cada vez mais ao reino da expressão e menos ao da representação, pôde conduzir o pensamento ao ideal de que a expressão do sujeito deve substituir toda forma de representação do objeto (cf. MATTÉI, 2001). O caminho para essa transformação, iniciada com a substituição do homem ético pelo homem estético no Renascimento - o que, segundo minha hipótese, legou uma vocação da arte à metalinguagem - culmina no desejo de emancipar a arte da obra, da forma, e até mesmo do material que o ofício do artista possibilitava a intervenção da ideia, projetualmente objetivada enquanto obra.

A definição de Heidegger dos tempos modernos como "a entrada da arte no horizonte da estética" buscou representar o entendimento de um processo absolutamente novo em que a obra de arte, longe de representar ou evocar um mundo, torna-se objeto do que se chama "experiência vivida", passando então por uma expressão da vida humana (ver MATTÉI, 2001, p.32).

São muitos os exemplos de como esse processo se deu. Ferreira Gullar encontra as raízes nos fenômenos artísticos dados no trinômio Papier Collé, Object Trouvé e Ready-mady. Na prática do papier collé se vê exatamente o que tentei outrora definir. $\mathrm{O}$ uso de objetos "reais" promove não uma desrealização, mas justamente o contrário: a inserção de um selo verdadeiro numa carta pintada num quadro de Picasso parece prenunciar justamente a "invasão" do real no mundo simbólico criado pela arte. Com o object trouvé, "os surrealistas afirmaram que criador não é apenas quem faz, quem acha também o é" (GULLAR, 1999, p.18). E quem acha, acha um objeto real, apenas descontextualizado do mundo das coisas.

O passo seguinte propõe a substituição do trabalho do artista pela pura e simples apropriação de objetos industriais. O deslocamento de contexto radicaliza um processo de desfuncionalização. A arte não dependerá mais do trabalho do artista. Eliminado o trabalho, eliminada a técnica, a arte estará emancipada da obra. Ser artista pode se resumir a ter um conceito, ter uma objetivação projetual puramente intelectual (cf. GULLAR, 1999).

A partir de então, o passo foi rumo a uma fragmentação, uma tendência para a não-arte, uma tendêcia ao nada. A apologia da não-arte: "Eu abaixo assinado Ben Vautier declaro autêntica obra de arte a ausência de arte". Ou Joseph Beuys, com a frase "Cada homem é um artista. Essa é mesmo minha contribuição à história da arte" exposta na fachada do Centro Georges-Pompidou (MATTÉI, 2001, p.34). Robert Klein: " Não é a arte que se detesta, mas o objeto de arte" em 1970 (ibidem, p.35). A prática dos 
enunciados iconoclásticos - Mattéi os chama de "enunciados performativos" - apresenta a prática de uma arte que não tem obra, tem apenas performances, e só poderá gerar reflexões superficiais e performáticas.

Ferreira Gullar identifica em Casemir Malevitch o processo de perda do suporte da arte como espaço simbólico e metafórico. Primeiro a eliminação da figuratividade. Depois, a tentativa da eliminação da dialética figura-fundo, quando se pinta um quadrado branco numa tela branca. O próximo passo: a eliminação do suporte, da própria tela.

\begin{abstract}
Ou seja, quando o pintor elimina totalmente, do quadro, a figura, o objeto, ele, quadro, se torna o objeto da pintura. Se não é mais possível pintar sobre o quadro, só resta pintar o quadro, como se pinta uma parede, uma porta. Esse quadro que já não contém ficção alguma, nenhum espaço virtual, é ele mesmo parte do espaço real do mundo - espaço sem transcendência, como um pedaço qualquer de tábua ou tela. Se eu crio um espaço metafórico (semântico, simbólico, ou o que for), eu sou pintor, estou fazendo pintura; mas, se desisto disso, então, o que me resta fazer diante do espaço inviolavelmente real e intranscendente da tela? Nada ou agir, isto é, usar da ação real, não-metafórica (o oposto do ato de pintar). Agir nesse caso é cortar a tela, furar a tela, queimar a tela, praticar ações "não-estéticas", ações que buscam uma outra transcendência que não é a da pintura, a da arte, tal como a entendíamos até então (GULLAR, 1999, p.25).
\end{abstract}

Morto o artesanato da obra, morto o mundo da obra, a barbárie do real é perpetrada numa arte que é puro conceito. O nada, a violência e a escatologia assinalam que "o império moderno da estética assina a morte da arte na dissolução da obra" (MATTEI, 2004, p.15). E essa violência resultante é provocada por um estado de barbárie, que Mattéi denomina como volonté d'anéantissement, vontade de aniquilação.

Das auto-mutilações do corpo em Rudolf Schwarzkogler ou Marina Abramović à escatologia de Piero Manzoni - Merda d'artista, com 90 potes com 30 gramas de suas próprias defecações, onde se inscreve: "Contém 30 g; conservado ao natural, produzido e embalado em 1961. Fabricado na Itália por Piero Manzoni (vendido ao preço de ouro a grama) - vê-se que a arte sem obras supera mesmo o antigo conceito de fealdade; agora, só o choque.

Se o radicalismo do pensamento de vanguarda pôde culminar na violência ao suporte da arte, é apenas conseqüente que possa resultar na violência ao corpo: da nulidade de On Kawara, pintando em fundo monocromático, desde 1966, dia-a-dia, as datas de cada dia, ao suicídio de um jovem artista japonês em Tóquio, saltando de um prédio sobre uma tela. A morte da arte talvez represente o signo da morte do humano, e 
a "morte do japonês acederá ao estatuto de 'obra' póstuma pela doação da tela ensangüentada ao Museu de Arte Moderna de Tóquio (MATTÉI, 2001, p.36).

É certo que estes fenômenos, em maior ou menor medida, se observaram e se observam em todas as formas de arte. Nas experimentações mais radicais no cinema e no teatro, onde a invasão do "real" destrói o sentido da ilusão, à escatologia que alude à própria situação da $\operatorname{arte}^{110}$. Mas nada foi tão radicalmente limítrofe quanto os desdobramentos da vanguarda das artes plásticas. Os efeitos desta radicalidade ocorrem conforme o esperado, tocando o seu lado oposto.

Se temos uma arte que é conceito, sem artesanato nem obra, temos a arte do puro pensamento. Esse mesmo que mata a possibilidade do pensamento estético, já que 'arte' se transforma em mera metáfora para o choque. No limite, uma estética para uma nãoarte redundará justamente numa não-estética. Ou: a estética é a própria arte, na medida em que se confundem o programa com o evento, já que não há obra, e o conceito de arte é a própria arte; morta a poíesis, resta a aisthesis. Não por acaso a vanguarda proclama um novo tipo de artista, o artista-teórico. Não o artista-teórico acadêmico, este de outra natureza; mas o artista que busca substituir a obra pelo projeto da obra, afinal, na sua ausência, é quase sintomático que se preencha essa lacuna com conceitos. E na ausência da possibilidade de apreensão de sentidos - quando a arte dispensa a palavra - é preciso preencher esse vazio de outra forma.

Os fenômenos que marcaram as artes da modernidade podem ser analisados de muitas formas. Importantes ensaístas da modernidade, como Marshall Berman (2007) por exemplo, buscaram essa relação entre os conteúdos dados nos fenômenos artísticos e o modo como os problemas materiais do mundo moderno se concretizaram nestas possibilidades expressivas não enquanto linguagem, mas enquanto possibilidade de expressão de conteúdos e ideologias. Mattéi se inscreve entre aqueles que buscam identificar os fenômenos artísticos com a possibilidade de que eles revelem algo do âmago, da essência, de nossa época (no caso de Mattéi, a barbárie, no de Berman, a solidez que se liquefaz, segundo a fórmula marxista), como se neles se refletissem os

${ }^{110}$ O filme húngaro Taxidermia (2006), de György Pálfi, é um exemplo da estética da fealdade e do conteúdo escatológico, mas ocorrente ainda na manutenção da linearidade da obra, o que permite, afinal, a crítica feroz deste mesmo estado de coisas que se demonstra. De fato, a crítica da barbárie da arte pode aparecer, ao cabo, não pela tentativa de singularização da obra, mas do homem-obra. 
ecos dos problemas sociais, morais e históricos vinculados a um homem que é sempre tomado como sujeito.

No entanto, de que maneira se pode associar a possibilidade de definição de arte, a partir do quadro que apresentei anteriormente, com este estado de coisas? Justamente em que medida um quadro onde se veiculam os três elementos - a formatividade, a desocultação, e a corporalidade - pode recuperar sentidos quando se proclama a inexistência da obra? Se a técnica pode ser apresentada não como mediadora, mas como o próprio fundamento da artisticidade, como pensar uma arte que proclama a técnica inútil? E, em que medida a radicalidade destes fenômenos se manifestam na música?

Diversos dos problemas da vanguarda podem ser examinados de formas alternativas, verificados numa relação próxima com a possibilidade de se pensar uma nova estética a partir dos pressupostos que procurei desenvolver.

Se de fato é possível verificar um percurso que marca a passagem do homem ético para o homem estético, esta mudança assinala a entrada da arte no campo de sua auto-análise. Como já demonstrado anteriormente, trata-se de um percurso gradual de uma arte sob o signo da possibilidade de sua verificação fenômenológica e por sua autoconsciência enquanto processo. Essa vocação a uma metalinguística pôde, ao meu ver, demarcar um duplo fenômeno, ambos residentes em processos que podem ser vistos como dialéticos. Por um lado esse auto-refletir-se e auto-referir-se é ao mesmo tempo uma agudização da transformação simbólica do mundo desferida pela imaginação projetual, e de uma tendência de volta do material da obra ao seu estado de ser-coisa. Uma vez que o processo formativo da obra se dá a saber, perde-se o desvelar.

Outro processo dialético ocorre com relação a minha outra hipótese: pari passu ao desenvolvimento de uma metalinguística, há uma tendência à manutenção do corpo, donde se origina a obra, e ao mesmo tempo ao seu abandono, em prol da exposição dessa organização conceitual da obra enquanto obra do pensamento, o que chamei como teleologia negativa. Processo de onde se deriva uma dialética entre uma tendência à manutenção e uma tendência à efemeridade da obra de arte.

A partir desses dois processos vocacionais é certo que a arte ocidental pôde produzir talvez as mais monumentais obras. No entanto, esse caminho, que também é o caminho da singularização e da autonomia, encontrou a sua radicalidade no desequilíbrio para um dos lados: o fenômeno do novo radical provoca não só o retorno à coisa como a dilaceração do corpo. 
Se o processo da formatividade, dado a partir de uma imaginação projetual que fere a matéria é logrado enquanto obra; se essa matéria, o mármore por exemplo, surge transformada, em seu esplendor - sua coisidade é ainda mais explícita - na medida que a técnica artística evidencia a sua brancura, a sua dureza, as suas características mais verdadeiras (pensemos no Moisés de Michelangelo, nas "transparências" de Corradini); se o real surgido desta transformação metafórica é, ao mesmo tempo, o ocultar da técnica e o brilhar da matéria; então, o logos se manifesta na arte segundo um dizer que é sempre um dizer diferente.

No entanto, o caminho que passa a expor o processo formativo pode ser o caminho do reconhecimento da matéria como coisa, do real como real. A balança se desequilibra e não há mais exposição de mundo, uma vez que qualquer linguagem, sendo por natureza tautológica - e é isso que a obra repele - e possuindo uma função, pode dizer o dito como qualquer dito, dito de qualquer maneira.

Se de início esse processo metalinguístico pôde expor todo um universo de possibilidades, como se a dialética do ocultar-desocultar pudesse promover uma tal tensão que as grandes obras puderam adquirir uma vivacidade singular, como aparece nas grandes obras de J. S. Bach ou de Aleijadinho por exemplo, é certo que uma cada vez maior adesão ao ideal de singularidade e individuação do artista na obra - o estilo pôde alcançar a radicalização de um processo onde a utópica busca por um singular absoluto é refletido pelo desejo do novo absoluto. E o novo absoluto, impossível, só pode ser assumido enquanto violência, ruptura. Ou se torna imperativo inverter o processo, o que só comprova a tendência a não só incluir a arte no mundo das coisas, como dizer que a obra é que faz violência à coisa. Por isso Malevich em uma famosa citação performática censurou Michelangelo por esculpir seu Davi: "Michelangelo fez violência ao mármore mutilando um pedaço magnífico de pedra", escreveu ele, com indignação. "O mármore desperdiçado foi violado desde o início pelo pensamento de Michelangelo sobre Davi" (MATTÉI, 2004. p.5).

Esta censura demonstra que não só a existência da obra fez violência à coisa; é a própria imaginação projetual, o insight (nos dizeres de Pareyson), o pensamento que buscou fornecer uma intenção significativa e permitiu que a estátua pudesse nascer é que foi censurado.

É desta forma que o equilíbrio entre as tensões polares que se dão na obra de arte se perde. A balança então pende para a coisa, e não para a transformação da coisa. Paradoxalmente, em estando a coisa, o corpo material, ligados à permanência numa sua 
sutil dialética com a efemeridade, a manutenção da coisa em seu estado de ser-coisa é uma permanência embotada pela cotidianidade, desgastada pelo mistério de sua existência não desocultada; é não-permanência enquanto é não-significado. E Fernando Pessoa pode estar certo, "Porque o único sentido oculto das cousas / É elas não terem sentido oculto nenhum".

De fato, a tensão entre um conatus sese conservandi e um conatus intelligende é não só perda do corpo, da matéria, da técnica e do artesanato: é não-permanência, é efemeridade. É um extremo do materialismo - uma tendência ao material, à própria coisa - que pela sua radicalidade atinge uma extremo do idealismo: arte é só ideia, só conceito; um evento efêmero. É certo que uma arte onde a obra é substituída por um programa de arte, é uma arte só insight, mas sem imaginação projetual objetivada na matéria. É uma poética dilacerada, já que se tem o programa, mas não poíesis.

É importante, neste ponto, que se possa examinar em que sentido essas questões se revelam no caso da música, de modo a complementar algo que já possa ter sido dito.

\section{O que se revela no caso da música}

Como o já dito anteriormente, a formulação básica sobre a morte da arte não se veicula de forma tão radical na música. E isso se dá devido a alguns fatores. Em primeiro lugar, a sua singularidade técnica parece repelir de forma mais veemente o universo diletante, sendo mais evidentemente de difícil domínio do que a da pintura, da escultura, da poesia.

A partir desta afirmação se poderia já levantar uma objeção: não ocorre justamente o oposto, dado que a música sempre fora, e a partir do século $\mathrm{XX}$ mais ainda, o terreno para a apreciação, invenção e atuação/interpretação do amador, terreno fértil aos diletantes?

De fato, nenhuma arte se mantém totalmente vetada ao amador. Do senso comum se poderia ainda recuperar a antiga ideia que associa mecanicamente o diletantismo ao campo das artes populares ou "ingênuas". Se de fato não se corre o risco em afirmar que as manifestações populares quase sempre estiveram mais ligadas ao diletantismo, é certo que a distinção dos universos musicais não se resume ao binômio profissional-amador, especialmente porque a dicotomia popular-erudito se liquefaz na medida em que se procura na história das artes a sua evidência: basta pensarmos o quão 
difícil seria trazer a noção profissional/amador conectada à ideia de popular/erudito para antes do Renascimento, ou aplicá-lo às manifestações artísticas não-ocidentais.

Por isso, não é do meu interesse aprofundar um estudo específico desta natureza $^{111}$, já que, o que me interessa, é justamente mostrar que a música enquanto fenômeno técnico é de mais difícil 'manipulação' do que muitas outras formas de arte, pelo menos no que diz respeito à desagregação da noção de 'obra' a partir das vanguardas do século XX. E isso se pode compreender em grande parte se pretendo me manter em consonância com a ideia de que no fenômeno técnico já estamos no fenômeno artístico (Formaggio, Heidegger).

É a partir disso que poderíamos pensar a objeção que me auto-infligi há pouco: malgrado seja na especificidade técnica da poética, no fenômeno artístico específico, que se pôde definir uma abertura à intervenção do não especialista, e, neste sentido, o limite de complexidade técnica a que a música passou a ser submetida desde o Renascimento tornou-a inacessível na maioria das vezes ao amador, foi especialmente no século XX - quando à emergência da indústria da cultura nascente - a maximalização da maior parte das poéticas da vanguarda deixou o público muito à vontade com as manifestações da indústria cultural, com sua música acessível.

Então, se temos que a música da indústria é justamente uma música de músicos amadores e produtores profissionais, no universo paralelo que se tornou a música contemporânea de concerto temos a inacessibilidade tornada programa de arte. Nunca se associou tanto a inacessibilidade a um juízo de valor como na vanguarda musical. Nem mesmo no romantismo.

Assim sendo, temos que é neste sentido e neste âmbito de análise que posso admitir a singularidade técnica da música como diferenciada segundo um nível de dificuldade de apreensão. E isso é fundamental para que se possa examinar uma distinção no âmbito das manifestações artísticas de vanguarda. E onde se verifica essa distinção?

O processo do novo utópico e ruptural, em sendo a música a arte do tempo e da liquidez, inicialmente só poderia se dar via manipulação temporal e do timbre, através de uma projeção teórica sólida. Garantir o novo, então, é postular uma nova teoria para

\footnotetext{
${ }^{111}$ Ferreira Gullar traz interessantes reflexões para esse campo. Em sua Argumentação Contra a Morte da Arte (1999), tanto na primeira parte, num texto intitulado Casa do Sonho (p. 57), quanto na segunda parte, capítulo IX (chamado Arte Ingênua, p. 105), Gullar reflete sobre os problemas da arte em sua relações entre o universo acadêmico e o espontâneo, o que em música normalmente, e de forma muito redutiva, se manifesta como erudita ou popular.
} 
cada nova obra, que seja, obrigatoriamente, desatrelada de postulados velhos, do passado. E isso, em temos de música, foi realizado através do desenvolvimento de possibilidades cada vez mais ligadas ao artesanato.

É notável como as diferenças das naturezas dos diversos tipos de arte não se resumem aos problemas técnicos, algo que podia ser postulado quando se tinha que a técnica artística é mediadora e não a própria natureza da arte. Se no caso das vanguardas das artes plásticas caminhou-se rapidamente da obra à coisa via abandono dos sistemas artesanais, no caso da música chega-se à coisa justamente via sistema artesanal. Se nas artes conceituais a máxima duchampiana de que arte pode se dar com a coisa (qualquer coisa) deslocada do seu contexto, sendo o artístico dado 'conceitualmente', na música a reflexão e o pensamento conceitual estiveram quase resumidos ao problema da teoriamétodo, no sistema que garante a obra.

Neste sentido, o pensar sobre música se tornou gradualmente sinônimo de pensar sobre problemas teórico-artesanais. Assim, a obra pensada na possibilidade do novo, na vanguarda musical, se dá em uma nova emersão da velha metafísica pitagórica, em sua relação com a possibilidade de uma nova formulação da relação arte-ciência. É neste sentido que o artista-teórico advém na música.

A garantia do novo se concretizará através da criação de uma formulação teórica nova, produzida para ser um regulador a priori. Na música, temos doravante a tendência a uma negação da formatividade, já que o ideal de determinação e autocompletude dado através de elaborações teóricas em torno do serialismo, busca evitar justamente "um fazer que enquanto faz inventa o modo de fazer": o modo está postulado de antemão, como sistema regulador cada vez mais em busca da consistência. Neste caso, pensando em Ferreira Gullar, a obra seria desnecessária, já que a resposta já está dada.

A prática das teorias apriorísticas e manifestos de arte se tornaram tão correntes que é difícil não os pensar como emblemas da modernidade nas artes. E é por esse viés, na música, que se chega ao abandono do corpo. Se na arte conceitual ele é banalizado e dilacerado numa quase-metáfora do seu abandono enquanto elemento de onde parte a projeção da obra, na música ele também é vítima, mas por outro viés conotativo: se a ênfase no sistema artesanal é uma espécie de exacerbação do trabalho elaborado no material, ou seja, uma espécie de materialismo poético, essa ênfase só pode ser atingida no âmbito oposto, dado num intelectualismo maximalista e idealista cuja complexidade cientifica é a culminância da negação do corpo: a vanguarda pós-weberiana busca "fixar o infinito" serializando todos os parâmetros, espalhando a música no tempo, explorando 
o aspecto tanto positivo quanto negativo da organização serial. Não por acaso, jamais o silêncio foi mais expressivo e mais valorizado na história da música. No entanto, toda a tentativa de determinação total dos parâmetros compositivos não deu ouvidos ao corpo. A ênfase na estrutura esquece-se, em parte, da realidade da escuta.

Henri Pousseur (1929-2009), teórico e compositor ligado à Darmstadt, já percebia que a total ênfase no controle e determinação dos parâmetros compositivos da obra, evitando toda a possibilidade de hierarquia a partir de uma busca da não repetição, resultaram numa situação onde "o detalhe não devendo ser idêntico em nenhuma parte, o estado global era de uma similitude, cujo interesse corria o risco de se esgotar rapidamente", levando à resultados onde ocorreu uma "paralisia próxima da impossibilidade total de agir e de se exprimir" (apud TERRA, 2000, p.44).

A tendência ao ideal do novo, resultante da busca utópica da singularidade total que levou à música contemporânea, de um modo geral (capitaneada pelos ideais da vanguarda serialista), a uma similitude sonora talvez imprevista, é parte do ideal positivista de progresso, pregnante na escola de Schönberg e no pensamento de Adorno, e evidente no postulado de Anton Webern:

\footnotetext{
(...) uma vez que a tônica na existe mais, ou melhor, uma vez que os acontecimentos progrediram a tal ponto que a tônica não é mais indispensável, sentimos a necessidade de impedir que um som qualquer predominasse, que a repetição de um dado som lhe 'conferisse vantagem" sobre os demais (WEBERN, 1984, p. 95).
}

Ao que parece, nos extremos do serialismo total toda obra é uma tônica, e a total diversidade leva a uma audição dada na estaticidade. Como o moderno de fato parece ter ocorrido nos extremos e na radicalidade, temos que a essa totalização da experiência composicional foi geradora de seu antítipo, substanciada na estética de John Cage. Não surpreende que o caminho para a indeterminação na música tenha encontrado sua mais acabada expressão também nas linhas herdadas de Darmstadt.

\subsection{Ingenuidades e paradoxos: determinação, indeterminação e silêncio na música da vanguarda}

A pesquisadora Vera Terra bem identificou que o ponto de partida para os extremos é o mesmo, então "tanto Cage quanto Boulez tomam como referência, na 
construção de suas poéticas, a obra de Anton Webern, o que os aproxima e faz perceber pontos comuns em suas pesquisas" (2000, p. 23). Cage teria se interessado pelo aspecto negativo, o silêncio, na obra de Webern, enquanto Boulez pelo aspecto positivo, nas possibilidades de permutação da série. Se Cage e Boulez representam os dois extremos da música, e partem de um mesmo ponto, em suas radicalidades se encontram: a determinação total e o aleatorismo podem, de fato, soar muito parecidos.

Os postulados de John Cage representam uma enorme influência ainda hoje. O abandono da noção de obra musical, algo que na música parecia não consubstancial à hegemonia da consistência, finalmente colocou a música sob o signo do nada. A pergunta, se na verdade toda obra de arte é conceitual - e aí está uma das ingenuidades da estética da vanguarda -, seria: qual a possibilidade de uma obra musical puramente conceitual? Em outras palavras, é possível uma música sem obra? Se sim, uma música sem artesanato? Sim, mas na música se chegou ao extremo da não-obra de forma mais tardia.

Se houve um debate em torno da música contemporânea que possa ter captado maior atenção dos especialistas, sendo o mais influente já ao final do século XX, este circulou na relação entre determinação e indeterminação na música. Cage e Stockhausen, a partir de novos postulados em torno da música aleatória, concebem o intérprete como co-autor. Boulez dramatiza a situação chamando essa prática de "fetiche do intérprete"; novamente nota-se certa ingenuidade quando é claro que todo intérprete, em algum nível, é co-autor. Mesmo o jazz, a esta altura, prevê uma prática onde o interprete intervém na linguagem - paradoxalmente de forma determinada - e não se limita a realizar uma hermenêutica das notas escritas. Mas mesmo no caso do desenvolvimento das ideias em torno da indeterminação na música, a princípio, se esfacela unicamente a possibilidade projetual, ou pelo menos ela tende a se dar de forma mais espontânea, uma vez que mesmo a improvisação livre (que pressupõe utopicamente o abandono de uma linguagem pré-estabelecida) conta com algum tipo de artesanato específico, o que ainda repele o amador: jogar um balde de tintas num quadro, defecar em potes ou levar um urinol para a sala de exposição são bem mais acessíveis ao diletante. Mas o passo em direção a uma música sem artesanato se dará.

Quando nos deparamos com a imagem (a música é pouco executada no Brasil) de um músico ou grupo de músicos e maestro diante de seus instrumentos, parados, concentrados, em atitude de execução de uma peça musical; a platéia atônita esperando a música. E, depois de 4'33", o intérprete indica a finalização da peça e aguarda os 
aplausos sem ter tocado sequer uma nota ao instrumento, cantado ou regido, não estamos diante de um pastiche, happening ou provocação gratuita. A música do compositor John Cage é referencia óbvia do radicalismo e experimentalismo que a arte musical alcançou a partir de meados do século XX, mas não deve ser (e de fato o tempo tratou de dizer que não foi) considerada uma irrelevância. As questões levantadas por Cage foram abordadas abundantemente e sobre vária perspectiva, se tornando quase óbvio citá-lo quando tratamos das mais radicais propostas musicais da música contemporânea.

Numa música sem obra, os paradoxos já apresentados se tornam mais evidentes: o compositor sem poiésis é só esteta. Por isso a não-obra ganha relevância apenas pela sua influência enquanto conceito. Numa linha em que se evidenciava uma precariedade de mundo pela radical ênfase na doutrina artesanal, é certo que se tocará o oposto. A arte sem obra postulada por Cage encerra um debate estético dos mais interessantes, uma vez que, por diversas vias, ele busca o nada: o confrontamento obra x processo, arte $\mathrm{x}$ vida, som x silêncio ou música $\mathrm{x}$ antimusica; enfim, sem poética, resta a filosofia do compositor, que envolve o questionamento da composição musical enquanto forma de linguagem e enquanto obra. Assim, ele procura abandonar a ideia de obra e substituíla pela noção de processo musical.

É interessante notar como a estética moderna da vanguarda oscila entre conceitos que são verdadeiros achados, e certas noções ingênuas onde o novo é apenas uma reedição do antigo apresentado muitas vezes inadvertidamente como novidade ${ }^{112}$.

Vê-se assim que Cage esforça-se por especificar o que seria a indeterminação no século XX, já que, sabiamente, reconhece o fator indeterminação em todos os tempos ele mesmo aponta o fator 'indeterminação' na Arte da Fuga de J. S. Bach - enquanto Boulez parece identificar o embate determinação-indeterminação como prerrogativa da contemporaneidade. Mas o próprio Cage ao assumir que uma "ação experimental é aquela em que o resultado não é previsível" também é ingênuo: obviamente não se trata de uma especificidade da ação experimental, mas uma dinâmica da própria arte desde que ela começou a ser concebida a partir de obras (CAGE, 1974, [1961] p. 39).

\footnotetext{
${ }^{112}$ Vera Terra em seu Acaso e Aleatório na Música (2000) também faz um importante apanhado das noções da estética de John Cage.
} 
Esta análise, para além da própria compreensão da obra enquanto possível manifestação de um espírito que a torna representante de seu período, ${ }^{113}$ poderemos pensar, mesmo dentro desta possibilidade de representação, num aspecto que, deliberado ou não, aparece como forma de manifestação do vazio ou do nada, ou da possibilidade do vazio ou do nada.

Esta me parece a emanação mais relevante da proposta cageana, mesmo que, em termos, o que ele tenha querido demonstrar tenha mais a ver como a negação deste vazio e deste nada, e tenha deflagrado o similar musical da proposta duchampiana: o som (qualquer som), num contexto onde se espera ouvi-lo como 'arte', se transforma em arte. É assim que o silêncio do músico que não toca e do cantor que não canta, silêncio que nunca é absoluto, é preenchido pelos sons ambientes que podem (devem?) ser percebidos como artísticos. Emancipa-se assim, neste extremo, a arte do elemento humano, via inserção radical do humano como obra (o ruído da platéia).

Sem obra, o silêncio é processo, evento musical. Sem técnica e artesanato, o deslocamento contextual proclama a artisticidade do acontecimento. É notável que, no pólo oposto da vanguarda, a radicalização do controle compositivo elimina o interprete, pelo menos no nível da hermenêutica da partitura (ainda há a platéia, quando há): a música eletrônica opta por abrir mão do 'risco-homem' via botão play de algum aparelho eletrônico específico, e a música, com técnica e com obra, não mais refém do corpo, se vê atrelada ao desenvolvimento da informática e do capital para acompanhar o seu desenvolvimento.

Não busco aqui uma crítica das poéticas desenvolvidas em torno dos paradoxos e extremos da música no século XX e XXI. De fato, busco um exame estético de uma situação crítica que envolve as artes sob o signo de sua morte, ou sob o signo da morte de alguns de seus parâmetros na forma como sempre foram compreendidos. E esta situação não se parece consubstancial à crise das ciências humanas conforme apontamos na primeira parte, especialmente apresentadas em Japiassu e Morin como um crise epistemológica?

\footnotetext{
${ }^{113}$ Devemos lembrar que uma música "silenciosa" de 1952 pode ser emblemática de um tempo de Guerra Fria, uma guerra aparentemente sem o ruído de bombas; ou ironicamente, uma vez que se tratou de muito barulho, mesmo sem bombas. Mas também devemos lembrar algo menos sério, quem sabe lúdico: muito antes de John Cage estrear, em 1952, sua 4'33", o humorista Alphonse Allais fez aparecer em 1885 a sua Marcha fúnebre composta para o funeral de um grande homem surdo, "com 24 compassos em branco precedidos da indicação lento rigolando". Ao contrário do que dizia Marx no 18 Brumário, na história do esnobismo dá-se justamente o oposto: "o que foi concebido como piada acaba por se repetir como coisa séria, suscitando admiradores incondicionais e exegetas apaixonados” (ROUVILLOIS, 2008, p.279).
} 


\subsection{A pulverização da vanguarda musical em outras possibilidades estético-poéticas}

Ao que parece, temos hoje na música contemporânea uma espécie de pulverização das estéticas e experimentos de vanguarda em inúmeras possibilidades poéticas e estéticas. Algo que nos anos 80, 90 e especialmente 2000, ficou evidente no Brasil a partir das guinadas de compositores como Gilberto Mendes (sem dúvida um dos mais interessantes do ponto de vista conceitual e experimental no mundo todo) e Jorge Antunes, representativos dos rumos possiveis para uma música pós-vanguarda. Isso tem ficado evidente nos diversos festivais e movimentos musicais de compositores, especialmente nas atualizações do Festival Musica Nova "Gilberto Mendes" e no movimento de jovens compositores baianos (MAB - música de agora na Bahia).

Se desde os anos 60 as reações dadas nos movimentos do minimalismo e da new consonance deram origens a muitos seguimentos alternativos à vanguarda - que ao seu modo se tornaram hegemônicos em seus campos, dado que o perfil das relações culturais no mundo globalizado parecem ir em direção à ideia de 'campos' - é certo que uma certa dificuldade em desatrelar a estética da vanguarda dos campos epistemológicos da música ainda é patente. A já polêmica resenha do musicólogo e compositor Marcos Câmara de Castro (2015) para o livro O Ofício do Compositor Hoje (TRAGTENBERG, 2012) é exemplar de uma situação que identifica essa dificuldade em desatralar a música brasileira contemporânea da estética da vanguarda, apresentando uma perspectiva crítica dessa manutenção e dos recortes que orientam as escolhas estéticas.

Essa apresentação é consubstancial à constatação da limitação da música contemporânea de concerto ao ambiente acadêmico, onde ocorre a confluência de grande parte dos ideais de vanguarda na música às linhas de uma determinada ideia de ciência, determinantes para sua permanência hegemônica nas academias. Mas nesse ponto, para conectar estes exames às minhas conclusões finais (quando houver), devo ainda levantar uma questão que pode fazer a ponte entre o problema da arte e o problema do delineamento epistemológico para um pensamento sobre arte, o que é uma ponte até as conclusões.

Não é ato do acaso que à não-permanência da música na ausência de sua concretização enquanto obra temos a permanência de suas teorias e estéticas. A arte enquanto manifestação efêmera, sob os auspícios da busca pelo novo, 
(...) toca numa questão essencial, já que a arte tornou-se, através dos séculos, a expressão do que de mais permanente o homem criou (...) A linguagem, por preexistir à obra, obriga o artista a lidar com o "velho", isto é, com formas e ideias que geraram (e foram geradas por) suas obras anteriores, de modo que a obra nova guarda consigo algo do passado, não pode ser radicalmente nova (GULLAR, 2006, p. 43).

Doravante, temos que uma arte sem obras, ponto culminante de um processo intelectual-conceitual que desequilibra a balança para desintegração da permanência, tornando-se uma arte sem linguagem, lega uma música do silêncio e do choque. Assim como um segundo olhar ao urinol-fonte não pode provocar choque nenhum e o conceito se embota e a coisa permanece coisa, uma segunda audição de 4' 33", em não se tendo a surpresa e o choque que causa o silêncio inadvertido da música, é um processo-evento, e se presta mais à publicidade da indústria do que à reflexão que se buscou provocar. Essa reflexão sim, registrada nos anais e nos livros, é que permanece. É desta forma que, "a busca do novo pelo novo", em não sendo uma arte que lida com a linguagem das palavras,

além de empurrar o artista para o aleatório (por não trabalhar no âmbito de uma linguagem, sua experiência nem se acumula nem se aprofunda), leva-o a substituir a obra pelo projeto da obra e a suprir a impotência dela enquanto linguagem (...) pelo discurso verbal (...) (GULLAR, 1999, p. 43).

Se as colocações de Gullar podem explicar a tendência à uma "teoria sem obras", por outro lado, no caso de uma caminho via hermenêutica da consistência, onde o músico-teórico é a necessidade de uma arte com ênfase nas teorias apriorísticas, penso em outra possibilidade hipotética: o processo metalinguístico deflagrado como vocação da arte pode ter atingido sua culminância na música, enquanto verbalização de um programa teórico a priori - as bulas, ainda um vício hodierno - uma vez que a música, quando desatrelada de um texto, ou seja, 'pura', não encontra meios de auto-explicar-se. Uma metalinguística da música, então, se concretiza na tendência a um estruturalismo que busca deixar evidente a construção e o engenho na obra. Em não sendo possível a autoexplicitação de suas complexidades, explica-se o engenho num postulado teórico dado a priori.

Ainda sobre essa questão, sem dúvida que Formaggio, para além de sua fenomenologia da técnica artística, é quem tenta uma teoria de sentido para a arte compatível com o modo como ela passou a se dar na época contemporânea: ele 
identifica a arte sob índice do nada e da nulificação, não no sentido do vazio e de uma arte sem obras, na forma como aqui enfatizei, mas no sentido de um profundo exame das conexões entre as manifestações artísticas e a história social, procurando identificar esse nada como uma essência pregnante desde as primeiras formulações gregas, identificando a culminância desta essência na manifestação emancipatoria dos objetos. Se Heidegger pode realizar uma poética abordagem dos sapatos de Van Gogh afim de mostrar em que sentido a arte é um desvelar, Formaggio busca identificar esse desvelar, na própria coisa-objeto, identificando já a essência do projeto de descontextualização funcional presente na arte conceitual. Mas não somente. O nada estaria ligado a esse processo metalinguístico, permeando suas possibilidades. Essa arte 'crítica' pode ser mesmo a crítica posta em poética:

\begin{abstract}
A arte crítica é aquela que se colocou sob o índice do nada, e assumiu este índice quando incorporou em si e nas suas próprias estruturas operativas, de um modo pleno e por vezes dominante, as formas da reflexão. Deste modo, através das categorias reflexivas, tudo é posto ou pode ser novamente posto em questão, a arte pode começar de novo, conscientemente - e é neste conscientemente que reside a novidade de grande parte da arte contemporânea - , todo o seu mundo, enquanto a unidade da obra tente a fragmentar-se, a ceder por todos os lados, a tornar-se improvável e problemática (FORMAGGIO, 1976, p.58).
\end{abstract}

\title{
16. Por uma definição de arte permeável: a integração de mais um elemento
}

Segundo uma definição de arte que pûs-me a tentar postular, que integra técnica, corpo, desocultação, formatividade a uma noção prévia de que a arte existe enquanto fazer diferenciado, e que ela se dá nas obras fabricadas por artistas, só se poderia explicar muitos dos problemas estéticos da contemporaneidade por um viés evidentemente negativo, já que a experiência contemporânea, em grande parte realizada via ideário vanguardista, se consubstanciou exatamente na negação destes elementos. Em alguns casos, subverteu-os; em outros procurou superá-los. Na maioria dos casos, no entanto, eliminou-os. Mas obviamente eu não poderia ceder à tentação de postular conceitos que os elimine em troca. É neste sentido que, após esse percurso, penso que algo da essência do projeto vanguardista - mesmo que na música suas manifestações mais radicais já tenham ficado para trás ou tenham se tornado epigonais - deve permanecer latente numa estética para os dias de hoje. 
De fato, minha definição de arte não será um postulado fechado, que possa ser apresentado dissertativamente em uma lógica discursiva. A definição de arte que venho tentando, e que agora se finaliza, se consubstancia na possibilidade da diversidade de arranjo dos parâmetros filosóficos que pude extrair dos filósofos. Assim, para cada campo, uma possibilidade de remodelação desses mesmos parâmetros. É uma forma de postular algo mais permeável, inclusive daquilo que a vanguarda pode deixar de herança.

Se de fato a técnica e o corpo foram negados na obra, tornada obsoleta, e se a formatividade compreendida como um fazer é superada na desintegração da noção de obra de arte, é certo que o desvelar, o parâmetro da desocultação, não foi de todo abandonado. Me arrisco a dizer que a noção de autonomia e funcionalidade - no sentido heideggeriano - permaneceu. Não só permaneceu como foi potencializado: a ideia de deslocamento contextual não seria prova disso? O objeto (ou o som) desfuncionalizado, é singularizado e autonomizado quando, em sendo uma simples e banal "coisa" ou apetrecho, é posto em um contexto concebido como artístico, a partir de um conceito que busca nele o seu desvelar. Ou seja, se a arte não se dá senão fora do parâmetro da funcionalidade, bastaria que uma coisa qualquer, deslocada do lugar onde ela existe segundo uma função, passasse a exercer um papel estético, de pura aisthesis. Assim, mesmo uma coisa intranscendente (uma pedra, um ruído) poderia ganhar transcendência quando posto a ser percebido como arte.

Mas se uma estética deve se servir da experiência (Pareyson, Eco, Formaggio), é óbvio que não se pode ignorar esta experiência apresentada em estado crítico. É neste sentido que minha proposta para uma possibilidade de definição de arte estaria incompleta se não apreendesse o que de mais essencial as manifestações modernas mais experimentais ou mesmo as mais radicais de vanguarda puderam legar. E essa essência talvez possa ser sintetizada da ideia de que o que é percebido como arte deve ser chamado arte: mesmo que uma arte sem obra ou uma música-processo. Se pensarmos esses postulados vanguardistas unicamente como manifestos ou programas específicos de arte, precários enquanto pensamento ou não, já teríamos uma estética que se confronta com o cânone, e o novo será de novo uma questão meramente conjuntural, podendo recorrer àquilo que não é velho, mas essencial: a ideia de que as manifestações artísticas representam o que é próprio do homem. 
CONCLUSÕES 


\section{Conclusões}

Quando iniciei esta espécie de narrativa-tentativa, eu tinha em mente investigar as possibilidades ainda latentes em uma disciplina que, segundo a minha própria experiência, vinha recebendo um olhar desconfiado; especialmente no meio acadêmico. Não só segundo a minha experiência, conforme pude constatar através de autores que isso também têm constatado. Também tinha em mente pensar os problemas da estética musical no sentido de encontrar determinadas respostas para questões concernentes à minha atividade como artista, numa espécie de auto-etnografia que pudesse partir do particular para uma hermenêutica mais geral. Para tanto, procurei pensar filosoficamente, ou pelo menos a partir de autores que assim pensaram, determinados problemas da arte e como as manifestações contemporâneas vieram a se dar, buscando uma compreensão não só de como ocorreram os desdobramentos específicos da música como também da possibilidade de os pensar hoje: a modernidade, este projeto inacabado, repele classificações estanques.

De fato, a contradição entre a hiperindividualização dos campos de estudo das artes e da música e as confusões conceituais que os mesclam inadvertidamente, apareceram-me como problema chave. Então, o caminho para uma proposta disciplinar revitalizadora deveria passar por uma tentativa de delineação epistemológica, empresa essa sem dúvida inalcançável em sua totalidade. Em primeiro lugar, pois seria preciso postular um teoria ou um programa, o que seria por demais pretencioso; em segundo, porque tanto a natureza multifária da experiência artística quanto a natureza paradoxal e extrema dessa modernidade onde "tudo que é sólido desmancha no ar" repelem suas coagulações em definições e conceituações rígidas. Mas me pareceu assertivo que o próprio exercício analítico em torno dos problemas epistemológicos relativos à experiência artística já indicariam caminhos que pudessem ser eficazes e reveladores, sendo já possibilidades concretas para uma outra estética, uma estética emergente.

Quem sabe a disciplina estética ainda pudesse resistir àquelas acusações corriqueiras, apresentadas inicialmente por Talon-Hugon? Quem sabe a própria constatação dos problemas epistemológicos não pudessem já apontar caminhos para que a estética ocupe um lugar a ela devido na análise dos problemas das artes? Penso que determinadas respostas foram dadas ao longo desta multifária reflexão, especialmente mostrando que a estética pode seguir por um caminho mais agregador. 
Foram várias as questões levantadas. E para elas busquei respostas que pudessem aparecer como possibilidades. Especialmente se pudessem ser examinadas das seguintes maneiras: como formas de associação entre os paradigmas dominantes ou emergentes das ciências com as artes; na demonstração de como a estética musical se desenvolveu e se relacionou e pode se relacionar com esses paradigmas; no exame de como as metafísicas das artes puderam distorcer as possibilidades de compreensão estética; demonstrando como a música pôde encampar uma antiga metafísica transformando-a em nova, e como ela se tornou consubstancial ao velho paradigma científico; especulando sobre como o meu próprio exame poderia também afetar a observação, afinal, a ideia de uma artista-filósofo poderia revelar um olhar diferenciado? Também procurei analisar em que medida se pode inverter uma atual situação onde as ciências humanas - em especial as sociais - têm ocupado paulatinamente o lugar da filosofia e por conseguinte da estética, e as ciências duras da estética musical, de modo que certos estudos puderam apontar caminhos.

De fato, foi-me necessário pensar no que seria a própria natureza da estética para tentar examinar o que seria próprio dela enquanto objeto. Para tanto, procurei uma abordagem pluridisciplinar, que por vezes se tornou interdisciplinar: à acusação (justa) de que a estética sempre esteve pregnante de idealismo, busquei pensar a partir de autores alternativos a este idealismo perspectivas epistemológicas para as estéticas, tentando ainda me manter num certo limite que pudesse ser tomado como próprio do campo da filosofia da arte. Eis o desafio. E de fato, encontrei nesses autores alguns postulados que buscam, para um paradigma emergente nas ciências, justamente a absorção da inventividade das artes (Boaventura Sousa Santos, Edgar Morin, Hilton Japiassu). E não seria este um ótimo caminho para a estética: assumir a natureza de seu objeto como guia para suas próprias epistemologias e métodos, libertando-se do complexo relativo à velha ciência positivista? Penso que sim; eis minha conclusão.

É notável que enquanto as propostas para uma nova ciência clamam pela inventividade artística, a estética, especialmente a musical, é ultrapassada e substituída por disciplinas musicais que clamam por epistemologias cientificas empiricomatemáticas. Vivemos tempos realmente interessantes.

De fato pude, verificar que a crise da estética também pode ser inserida no contexto da crise das ciências humanas, levando a sério em minha abordagem os dizeres de Hilton Japiassu: 
Para superarmos essa crise, precisaríamos restabelecer seu caráter histórico, crítico e reflexivo, se é que pretendemos nelas recuperar o sentido do debate e da vida intelectual, contra uma tecnização pretensamente científica tentando despojá-las de humanidade (JAPIASSU, 2012, p.27).

As propostas que procurei lançar, a partir dos exames realizados na primeira parte, circundaram estes problemas. De fato, tomei a abordagem de Luigi Pareyson tanto como um guia metodológico quanto para tentar compreender a natureza da filosofia, especialmente aquela que ele chama como revelativa. Esta foi uma forma de averiguar quais seriam as possibilidades limítrofes para nos libertarmos do velho autonomismo idealista e assumirmos um materialismo que pudesse ser renovador, sem tornar, no entanto, a estética efetivamente o campo de estudo empírico do especificamente social, podendo doravente me apropriar de suas conquistas. Cobrar dela que se transforme em algo não substancial à sua própria natureza, é torná-la inútil.

Os campos da história, da sociologia, da psicologia e da antropologia, dentre outros, podem desempenhar o seus papéis na abordagem desse fenômeno a que muitos chamam arte, a partir de suas próprias vocações de forma mais eficaz: o homem e a sociedade, sua percepção, seus contextos.

Neste sentido, Pareyson fornece meios para pensar uma filosofia que abarque estes caracteres: assumir que a obra se dá no seio das culturas e que os dados dessas disciplinas favorecem um pensamento estético não autonomista. Eis um caminho.

Procurei, a partir da segunda parte, pensar qual seria então uma possibilidade que incluísse uma certa noção materialista dentro de propostas epistemológicas de natureza estética. Tentando romper com a mecânica conceitual que associa a disciplina aos vícios metafisicos idealistas, mas sem fazer com que a estética pudesse realizar aquilo que as epistemologias ligadas às ciências humanas podem realizar melhor, concluí: a vocação da estética, em se tomando a abordagem pareysoniana sobre a filosofia, é para a obra, para o fato estético, para o mundo da obra e de quem a fabrica. Por isso os vícios autonomistas. Seria então possível examinar o mundo da obra sem que o idealismo autotélico a desconectasse do mundo dos homens, como ocorreu em toda a estética croceana, hegemônica por tanto tempo, ou sem se especificar nas análises de cunho empírico-matemático? Sim. Para tanto, uma necessidade se revelou: seria preciso uma estética que pudesse proporcionar, sem ser especificamente uma crítica, uma contestação do cânone. Neste sentido, durante todo o percurso traçado, busquei respostas possíveis para os problemas levantados, apresentando conclusões 
especialmente ligadas as proposições de Umberto Eco (página 85 do presente trabalho). Mas, se sim, como?

Para especificar esse "como", caso contrário eu poderia ter encerrado este trabalho naquele mesmo ponto, era preciso pensar que a estética, segundo Pareyson (e também Eco e Formaggio) deve estar situada "no ponto de conjunção de filosofia e experiência" (PAREYSON, 1988, p.19). Assim, colateralmente ao meu objetivo de pensar os problemas da disciplina, tentando ora defendê-la ora pensar alternativas, procurei então traçar um caminho de sua relação com os problemas musicais desde o seu surgimento; este é o modo que encontrei para relacioná-la com a 'experiência', no caso, tanto da filosofia como da música. Pude constatar algo, que apesar de aparentemente óbvio, sempre ganha novas cores quando examinado de perto: a imbricação entre as poéticas e as estéticas é fecunda não só de notáveis avanços retroalimentados, como principalmente de distorções. Por isso a distinção proposta por Luigi Pareyson entre poética e estética é de uma imensurável contribuição. De fato, a percebo como anti-canonica, já que busca evitar que o pensamento sobre arte possa ser um instrumento legitimador das poéticas interessadas.

De qualquer forma, pensando o problema da experiência no que diz respeito à contemporaneidade, concluí que só seria possível completar um quadro de possibilidades para disciplina, caso prosseguisse com esse exame das imbricações entre as poéticas e estéticas, adentrando o século XX e analisando suas constantes. Mas para isso seria necessaria uma elaboração que me pudesse servir de parâmetro. Minha intenção, então: verificar a possibilidade de uma definição de arte que pudesse ser polivalente, fornecendo ao mesmo tempo um quadro de possibilidades conceituais através do qual uma estética para os dias de hoje pudesse se verificar, e que fosse por si só a construção de um objeto que a esta mesma estética que vim delineando pudesse ser consubstancial.

Então, indo nesta direção, busquei na estética de três filósofos do século XX a possibilidade de extrair parâmetros para uma definição de arte que me servisse de lente e ao mesmo tempo fosse uma investigação sobre a própria natureza da arte, uma vez que, como tentei desde início demonstrar, a própria crise da estética está relacionada a gradual morte da ideia de arte: seja no plano das poéticas, com as vanguardas; seja no plano das epistemologias, onde as ciências humanas tendem à compreensão da obra de arte como algo indiferenciado das coisas do mundo da cultura, e as ciências empírico- 
matemáticas tomam a música segundo a consistência de seu engenho, e a avalia pelo engenho de sua estrutura.

A tentativa de uma definição e a escolha de filosofias norteadoras já são escolhas estéticas; neste sentido, as minhas indicaram um caminho para onde uma nova estética pode se realizar: um caminho de recuperação de sentidos para arte, reconhecendo a necessidade de atualização e de relação interdisciplinar, já que "a arte é (...) um sistema de significações e não um sistema de coisas como o mundo material" (GULLAR, 1999, p.26), mas é consubstancial a ele e dele faz parte; um caminho alternativo que não esteja unicamente sob o índice do nada, da nulificação, e da aniquilação, antes, volte a se equilibrar nas fecundas dialéticas de sua permanência; um caminho rumo ao pensamento crítico, que, malgrado tenda ao mundo da obra por sua própria natureza, seja contestador dos cânones e não deles formador; por fim, que possa ser uma via para um pensamento agregador da vida do homem e do mundo da vida, em suas múltiplas conotações: concluo que a disciplina pode reter em si o Lebenswelt, o mundo da experiência vivida ${ }^{114}$, como o postulado da fenomenologia de Husserl, também ligado à interpretação sociológica de Habermas. Como nos indica Morin, para Husserl, Lebenswelt é o fundamento de todas as questões epistemológicas.

Parte dessas conclusões e reflexões surgiram da possibilidade de se encontrar elementos para esta definição; uma definição que não se apegasse às antigas metafísicas mas pudesse levantar a possibilidade de um materialismo estético: se em Heidegger procurei a distinção entre o mundo da obra e o mundo das coisas, opondo uma hermenêutica da coisidade e da consistência à recuperação da ideia de que a obra expõe um mundo, que ela é um combate à efemeridade e que o fato estético é um desvelar, pude encontrar em Pareyson um passo adiante na constituição de uma possibilidade material na abordagem artística. É notável que Luigi Pareyson tenha desenvolvido sua Teoria della Formatività no sentido de romper com a hegemonia idealista de base croceana. No entanto, a 'pureza' teorética de seus postulados, baseados em distinções e esclarecimentos conceituais, faz com que sua aplicação seja muito expansiva: se como pude desde o início mostrar a estética musical foi uma importante legitimadora de uma teleologia de matriz germânica, que a partir das noções do "absoluto" permaneceu como o principal cânone da música ocidental, é certo que esse fenômeno continuou no século

\footnotetext{
${ }^{114}$ É importante não confundir essa "experiência vivida" do Lebenswelt com o ideal artístico da arte conceitual, onde se prescinde da obra em prol da "experiência vivida"; neste caso, trata-se de conceber a obra tanto como extensão transformadora e geradora desta experiência, quanto como resultado dela.
} 
XX, verificado na permanência e na pregnância das teorias vinculadas à escola de Schönberg, e depois via escola de Darmstadt. A estética italiana que buscou se libertar do idealismo croceano pôde servir para uma tentativa de desatrelar a música nova da hegemonia da vanguarda. Neste sentido, o resgate da formatividade para exemplificar a dinâmica pela qual a obra se realiza como puro êxito me forneceu mais substância para uma definição; e ao mesmo tempo mostrou como uma estética da música pode se voltar também para um aspecto que inclua toda operosidade humana mas a distinga de uma operosidade característica do mundo da arte.

A partir do pensamento de Dino Formaggio, mais uma contribuição da estética italiana do século XX, um parâmetro complementar: o materialismo do filósofo se declara consubstancial a uma arte sob o índice do nada e da nulificação, mas identifica nela uma essência que é corporalidade e materialidade. Formaggio pôde me fornecer o conceito de que a técnica é já o fenômeno artístico e que o corpo e a matéria são elementos que disparam a possibilidade projetual na matéria que se fará obra. Malgrado Formaggio seja crítico do suposto anseio de aplicabilidade universal da teoria de Pareyson - ele coloca sua própria estética como estando em relação unicamente ao estado de coisas de onde ela emerge, e no sentido pareysoniano poderíamos dizer que ela seria uma filosofia expressiva - ele revela um caminho para se pensar a arte como um nada que é nulificação do nada, morte da morte, e ao mesmo tempo a invenção de um mundo mais real que o real.

Assim sendo, sugeri uma definição que imbricasse - na forma da recuperação de sentidos perdidos ou fragmentados na contemporaneidade através dos quais a arte sempre se moveu (conhecer, exprimir, fazer) - estes elementos destes três filósofos, compreendendo que uma estética musical pelo viés material poderia ocorrer a partir da constatação daquilo que se perdeu, por isso uma teleologia negativa: o corpo, a matéria, abandonados, chegam ao máximo de sua negação, dilacerados e declarados inúteis para a arte moderna.

No entanto, se postulei a necessidade - tanto epistemológica, tanto para uma definição de arte - de uma recuperação, é porque algo foi perdido. Neste ponto, busquei examinar, tendo este quadro definitório como lente, o pensamento e a arte de vanguarda.

Neste exame foi possível averiguar e especular sobre os inúmeros paradoxos, conquistas e precariedades que as estéticas da vanguarda puderam legar. Julguei importante, especialmente neste caso, a comparação entre a música e as manifestações de outras artes, para, justamente, reforçar aquilo que seria próprio da música. 
Procurei um sentido conclusivo a partir da análise de diversos paradoxos, abordando o modo como se dá o cânone estético-poético da vanguarda musical, especialmente no embate determinação-indeterminação na música já em finais de século XX e com efeitos nas múltiplas tendências deste início de XXI.

Se minha análise foi, ou flertou com a crítica, foi apenas porque trata-se de um estado crítico posto em poética. Se ela ocorreu deliberadamente por um viés negativo, é porque os sentidos que postulo foram abandonados, negados ou destruídos pelo pensamento de vanguarda. Portanto, um sentido negativo tomado como método, foi melhor forma de recuperar determinados sentidos e explicar determinados fenômenos.

No entanto, finalizei o estudo da vanguarda concluindo que minha definição ainda estaria incompleta, caso não extraísse de sua experiencia estética e de suas conquistas (muitas vezes questionáveis) um complemento para minha definição. A experiência das artes de vanguarda são parte fundamental da experiência da modernidade. Declarando-a morta ou ignorando-a, cairia eu também na possibilidade de uma narrativa totalizante, e o problema mais sério da disciplina ainda se manteria. Isso seria admitir a ideia do novo que eles mesmos postularam. Enquanto houver obras (ou não-obras) caudatárias ou realizadas segundo as teorias e conceitos da vanguarda mesmo em seus desdobramentos atuais no maximalismo, na nova complexidade, música espectral etc. - ela não estará morta. Ademais, matá-la, também seria assumir uma estética ainda sob o índice da morte. Assim sendo, os ditames do nada e da aniquilação podem ainda sobreviver e merecem uma possibilidade de participação na definição de arte que tentei; quem sabe fornecendo a ideia de que arte é aquilo que se quer perceber como arte. O que mudaria, então, na percepção do que hoje a arte pode ser? A resposta: um caminho de múltiplas vias, onde a arte de vanguarda e sua herança é apenas mais uma dentre muitas possibilidades e programas de arte, sendo co-partícipe de um tempo que repele a noção de totalidade. "Apenas" aqui, não é a tentativa de uma sobrevida indevida, nem uma diminuição vingativa. É apenas parte da conclusão de que a estética deve ser uma disciplina atualizada com a ideia de que os múltiplos campos não formam mais uma pirâmide. As manifestações por tanto tempo hegemônicas são apenas algumas dentre tantas, e as definições de arte e da estética devem se dar a partir de elaborações epistemológicas plurais, com possibilidades de imbricações, e no caso da música, compatível com a liquidez e permeabilidade de seu objeto. Por outro lado, é certo que estamos apenas começando: agora, uma tentativa pluridisciplinar, às vezes, quando possível, interdisciplinar. Mas a tão sonhada transdiciplinaridade, penso, ainda está 
longe. É tempo de sectarismos mais agudos, de defesas ferrenhas de campos acadêmicos, de lidar com fantasmas. A natureza da arte, sua polissemia, sua inventividade condicional, de fato, pode ser inspiração para novas epistemologias em todas as áreas; mas ao mesmo tempo o dado das especificidades técnicas e suas resemantizações são resistentes às formulações mais rígidas. Por isso, uma nova estética talvez logre mais sucesso se funcionar como um caleidoscópio: é necessário desterritorializar para entender melhor, amalgamar para um olhar mais completo, mas acima de tudo, reconhecer que, nos extremos, no limite, só encontra o que se quer negar. Inclusive a pluralidade da experiência:

Hoje a fusão, tantas vezes dissonantes, de grito e maneira poderá levar a uma reconsideração do caráter plural do trabalho artístico, que passa pela mente, pelo coração, pelos olhos, pela garganta, pelas mãos; e pensa e recorda e sente e observa e escuta e fala e experimenta e não recusa nenhum momento essencial do processo poético (BOSI, 1986, p.71).

Iniciei todo o percurso deste ensaio com a bela fala de Borges. Penso que devo terminar com ela, desta vez traduzida:

\begin{abstract}
A música, os estados de felicidade, a mitologia, os rostos trabalhados pelo tempo, certos crepúsculos e certos lugares querem nos dizer algo, ou algo disseram algo que não deveríamos ter perdido, ou estão a ponto de dizer algo; esta iminência de uma revelação que não se produz é, quem sabe, o fato estético (BORGES, 2015 [1950], p.237).
\end{abstract}

Se de fato incluo em minha definição de arte - além da ideia de que ela pode se dar através das obras produzidas por artistas - também aquilo que pode ser percebido como arte, que ao menos a experiência deste hecho estético não se resuma ao choque e ao nada, e possa ser também algo para além da banalidade. Quiçá uma outra forma, também artística, de o homem buscar a permanência, de se construir fora de si. Afinal, o problema da arte não estaria, ao fim e ao cabo, na possibilidade de "transformar o mundo em fala poética, uma vez que, para acrescentar à vida mais banalidade, não se faria necessário o artista?" Foi assim que "a necessidade de transcender a banalidade fez nascer a arte, modo de transformação metafórica do mundo. E que, se por ser metafórica é menos que a transformação real, é também 'mais': porque a realiza de imediato e 
porque o faz numa direção em que a ação real jamais o consegue" (GULLAR, 1999, p.26). Isso deve ser levado em consideração.

No início deste trabalho meu titulo era: por uma nova filosofia da música nova; pensei em estabelecer uma ideia de novo alternativa àquela claramente alusiva à Filosofia da Música Nova de Adorno (sem fugir de uma certa ironia). Confesso, ao fim, que me arrependi quanto ao novo, uma velha categoria. Usá-lo seria talvez remexer no exaurido. Talvez estejamos entrando num novo diferente. Esse novo, é o outro. 
APÊNDICE 


\section{A Atualidade do Festival Música Nova}

Enquanto eu terminava esta tese, construída por meio desses ensaios, faleceram, num espaço de 5 dias, dois compositores emblemáticos de quase tudo o que procurei examinar: Gilberto Mendes (1922-2016) e Pierre Boulez (1925-2016). Então, neste apêndice, onde há muito tempo eu havia planejado transcrever o texto de apresentação do $48^{\circ}$ Festival Música Nova "Gilberto Mendes" (2014), escrito por ele próprio, pelo diretor artístico do festival - Rubens Ricciardi -, e por mim, as coisas tomam ainda mais relevo. O texto, na verdade, é um quase-manifesto: embora não postule exatamente um programa de arte, deixa entrever algumas tendências. Embora seja crítico com relação a determinados aspectos, entre eles as tendências da vanguarda, não a exclui; antes, se vale de alguns de seus artifícios - uma certa ironia e o próprio caráter de manifesto - para uma autorreflexão dos problemas da música nova. De muitas maneiras Boulez e Mendes podem ser dois opostos. Mas aqui, a relação entre eles pode gerar muitos frutos.

\section{A Música Nova da Polifonia de Notre-Dame ao Século XXI}

O FMN já possui certo distanciamento crítico para poder se auto-avaliar desde sua nova proposta, em 2012, quando o SESC-SP em conjunto com a USP de Ribeirão Preto passou a sediá-lo, com a inclusão, na programação, da música nova de todos os tempos - desde a invenção da própria música, tal como a entendemos, pelas mãos dos gregos antigos.

Esta mudança de rumo talvez tenha suscitado alguma querela. Perguntou-se, afinal, por que estaria presente a música do passado - como Machaut, Gesualdo, Bach ou Beethoven - junto às composições vanguardistas das velhas linhas de Darmstadt, ao lado de composições minimalistas, eletroacústicas, espectrais ou texturais, entre os gestos característicos da improvisação livre e os conglomerados poli-estilísticos pósvanguarda? Será que em algum lugar se perdeu a essência experimental do FMN? Com o novo sucesso de público, desde 2012, temos de fato a negação do experimentalismo? Muito pelo contrário.

Inicialmente, há que se compreender as diferenças entre experimentalismo e vanguarda. Para Umberto Eco, "toda verdadeira invenção artística é experimental em todos os tempos e lugares. Neste sentido, a música polifônica era experimental em relação ao cantochão. Beethoven era experimental em relação a Haydn, e assim sucessivamente". Stravinsky, Bartók e Villa-Lobos foram altamente experimentais e inventivos em seus trabalhos com as músicas populares já urbanas, desde Brahms com 
suas danças húngaras e Chopin com suas mazurcas. Ainda para Umberto Eco, "entre os séculos XII e XIII, os compositores polifonistas de Notre-Dame foram experimentais quando adotaram o intervalo de terça pela primeira vez para que se tornasse aceito pela sensibilidade musical corrente". Umberto Eco conclui que, ao contrário das "lentes deformantes de uma sabedoria tradicional e autoritária, faz parte do experimentalismo a constante transformação do método, falando com simplicidade". Ou seja, o experimentalismo é uma postura incansável de mudança e auto-superação. Neste mesmo sentido, já distante da rigidez da velha vanguarda e aberto à música nova de todos os tempos, o FMN permanece experimental, porque entende que nossos tempos são dos sistemas abertos, bem como dos diálogos entre os sistemas.

Não somos nós, mas sim Charles Baudelaire quem já há muito percebia a armadilha na tradição das metáforas militares, como no caso de se pensar numa vanguarda (conceito de origem evidentemente militar) no contexto artístico. Baudelaire chamou a atenção para "os poetas de combate", para "os literatos de vanguarda", cujos "hábitos de metáforas militares denotam espíritos não militantes, mas feitos para a disciplina, isto é, para o conformismo, espíritos nascidos domésticos”. Seria uma visão profética de Baudelaire? O que antes se pensava como inovação e desprendimento não pode agora se transformar numa doutrina de corporação, cuja assimilação, obediência e fidelidade diante da patrulha ideológica adquirem mesmo os rigores de uma hierarquia militar? Seria o caráter evidente de exclusão em nome da uniformidade. Nossa proposta, desde 2012, ao contrário, contempla a pluralidade, o não-padrão, e, acima de tudo, a inquietude filosófica.

Schönberg, um dos gurus da primeira vanguarda pós-guerra, afirmou "ter orgulho em escolher uma má estética para os alunos de composição, se em compensação der a eles um bom aprendizado de artesanato". Esta ideologia gerou alguns resultados desastrosos em Darmstadt e continua gerando em seus últimos epígonos ainda hoje - não obstante várias de suas importantes contribuições históricas. Está claro que houve certa precariedade filosófica na geração dos compositores da vanguarda autoproclamada. Permaneceram na superfície de uma autoidolatria tanto excêntrica quanto excludente. Assim, esqueceram-se do mundo. Não é por menos que também o mundo se esqueceu deles e nem cabe aqui lembrá-los mais enquanto único caminho para a música nova. Ao contrário, vamos nos lembrar agora também daqueles que eles tentaram esquecer. É por isso que apresentamos nesta $48^{a}$ edição do FMN obras de compositores como Villa-Lobos - historicamente execrado pelas primeiras fileiras da 
velha vanguarda - e também o já centenário Guerra-Peixe, ao lado de uma compositora inédita no Brasil, a alemã Dorothea Hofmann, nossa compositora residente desta edição 2014 do FMN.

Com três sedes em 2014, Ribeirão Preto, São Paulo e Santos, o FMN se consolida cada vez mais em sua $48^{\mathrm{a}}$ edição por meio do trabalho conjunto do SESC-SP com a USP de Ribeirão Preto, com seu caráter didático enquanto festival que além de concertos oferece também cursos, procurando viabilizar sempre já um maior acesso do público em geral à música nova, ampliando e abrindo assim o espaço da música de concerto de nossos tempos.

por Gilberto Mendes, Rubens Russomanno Ricciardi e Lucas Eduardo da Silva Galon 2014 
REFERÊNCIAS 
ADORNO, T. W. Introdução à sociologia da música. Tradução de Fernando R. De Moraes Barros. São Paulo: Unesp, 2009 [a partir da edição de 1968].

ADORNO, T. W. Philosophie der neuen Musik. AGS XII.Frankfurt am Main: Suhrkamp, 1975 [1 ${ }^{\text {a }}$ ed. 1949].

ADORNO, Theodor. Filosofia da nova música. Tradução de Magda França. São Paulo: Perspectiva (Estudos), 2011 [1958].

ALMEIDA, Jorge de. Crítica dialética em Theodor Adorno - Música e verdade nos anos vinte. Cotia: Ateliê, 2007.Alves. Petrópolis: Vozes, 1993 [1 $1^{\mathrm{a}}$ ed. 1954].

ANDRADE, Mário de. Ensaio sobre a música brasileira. São Paulo: Martins, 1962 [1ª ed.1928].

BERIO, Luciano, Entrevista sobre música. Realizada por Rossana Dalmonte.Tradução de Álvaro Lorencini e Letizia Nunes. Rio de Janeiro: Civilização Brasileira, 1981.

BERMAN, Marshall. Tudo que é sólido desmancha no ar. Tradução de Carlos Moisés e Ana Ioriatti. São Paulo: Editora Schwarcz, 2007 [1982].

BORGES, Jorge Luis. A muralha e os livros, In: Nova Antologia Pessoal. Tradução de Davi Arrigucci Jr., Heloisa Jahn e Josely Vianna Baptista. São Paulo: Companhia das Letras. 2013.

BORGES, Jorge Luis. El hacedor. 14ª ed. Madrid. Alianza Editorial S.A. 1998 [1960].

BORGES, Jorge Luis. El otro. In: El libro de arena. Madrid: Alianza Editorial, 1998.

BORGES, Jorge Luis. La muralla y los libros, In: La Nacion. Buenos Aires, 1950.

BOSI, Alfredo. Reflexões sobre arte. São Paulo: Editora Ática, 1986.

BOULEZ, Pierre. Alea. In: Relevés d'apprenti ('Tel quel'). Paris, Seuil, 1966 [1957].

BOULEZ, Pierre. Anton Webern. In: Relevés d'apprenti. Paris, Seuil, 1966 [1961].

BOURDIEU, Pierre. O amor pela arte na Europa e seu público. Com Alain Darbel; Tradução Guilherme João de Freitas Teixeira. 2 ${ }^{\mathrm{a}}$ Ed. São Paulo: Editora da Universidade de São Paulo; Porto Alegre: Zouk, 2007.

BRELET, Gisèle. Esthétique et création musicale. $1^{\text {a }}$ Ed. Paris: Presses Universitaires de France, 1947.

CAGE, John. Silence. Middletown, Wesleyan University Press. 1974 [1961].

CÂMARA DE CASTRO, Marcos. Música Erudita Contemporânea: Valor Estético e Valor Simbólico. Artigo publicado nos Anais do XX Congresso da ANPPOM, 2010. 
CÂMARA DE CASTRO, Marcos. Resenha de O Ofício do Compositor. Art Research Journal / Revista de Pesquisa em Arte ABRACE, ANPAP e ANPPOM, 2015.

CAMUS, Albert. O avesso e o direito. Tradução: Valerie Rumjanek. 6 edição. Rio de Janeiro: Record, 2007 [1958] .

CERVANTES. Miguel de. O Engenhoso Fidalgo dom Quixote de la Mancha. Tradução de Eugênio Amado, Belo Horizonte : Editora Itatiaia, 2005.

CESCA, Sara Cecília. Teoria della Formatività:reflexões sobre a invenção e a produção artística em diferentes contextos educativos. Universidade de Campinas: Dissertação de Mestrado, 2015.

CHU, Yu-Kuang. Interação e linguagem no pensamento chinês. In: Ideograma, lógica, poesia e linguagem. Traduzido por Heloysa Dantas. São Paulo: Cultrix, 1986.

COOK, Nicholas (org.). The Cambridge History of Twentieth-Century Music. Cambridge: Cambridge University Press, 2004.

COOK, Nicholas. The Schenker Project: Culture, Race, and Music Theory in Finde-siècle Vienna. Oxford: Oxford University Press. 2007.

COOPER, Anthony A. Sensus Communis - A decisão de Hércules - Lord Shaftesbury. Tradução de Luiz Nascimento (2012), 1709.

DAHLHAUS, Carl. Estética Musical. Tradução de Artur Morão. Edições 70, 2003.

DAHLHAUS, Carl. La Idea de la Música Absoluta. Traducción: Ramón Benito. Barcelona: Idea Musica, 1999.

DeNORA, Tia. After Adorno, Rethinking Music Sociology. Cambridge: Cambridge University Press, 2003.

ECO, Umberto. A Definição de Arte. Tradução de José Mendes Ferreira. Lisboa: Edições 70, 1972.

ECO, Umberto. Cinco escritos morais. Tradução de Eliana Aguiar. $5^{\mathrm{a}}$ ed. Rio de Janeiro: Record, 2001 [ $^{\mathrm{a}}$ ed. 1997].

ECO, Umberto. Sobre os Espelhos e Outros Ensaios. Tradução de Beatriz Borges. Rio de Janeiro: Nova Fronteira, 1989.

FEYERABEND, Paul. Adeus a Razão. Rio de Janeiro: Edições 70, 1991.

FEYERABEND, Paul. Contra o Método. Rio de Janeiro: Francisco Alves Editora, 1977.

FORMAGGIO, Dino. Arte. Tradução de Ana Falcão. Lisboa: Editorial Presença, 1976.

FORMAGGIO, Dino. Arte. Traduccion de Jose-Francisco Ivars. Barcelona: Editorial Labor, 1976 [1973]. 
FORMAGGIO, Dino. L'arte come comunicazione. I. Fenomenologia della tecnica artistica. Milano, Nuvoletti. Pubblicazioni della Facoltà di Lettere e Filosofia dell’Università degli Studi di Milano, 1953.

FUBINI, Enrico. Estética da Música. Tradução de Sandra Escobar. Coimbra: Edições 70, 2008 [1993].

FUBINI, Enrico. La Estética Musical Desde la Antigüedad Hasta el SigloXX. Tradução de Carlos Guillermo Pérez de Aranda. $3^{\circ}$ ed. Madrid: Alianza, 2002.

GALON, Lucas E. S. Nacionalismo, neofolclorismo e neoclassicismo em VillaLobos: uma estética dos conceitos. Dissertação de mestrado ECA-USP. São Paulo, 2011.

GINZBURG, Jaime. Crítica em Tempos de Violência. São Paulo: Edusp, 2013.

GLEISER, Marcelo. A Dança do Universo. São Paulo: Editora Schwarcz Ltda., 2007.

GOEHR, LYDIA. The Imaginary Museum of Musical Works: An Essay in the Philosophy of Music.Oxford:Clarendon Press. 1992

GOMBRICH, Ernst H. A história da arte. Tradução de Álvaro Cabral. 16 edição. Rio de Janeiro: Editora LTC - Livros Técnicos e Científicos Editora S.A, 1999.

GRAMSCI, Antonio. Cadernos do Cárcere XI. In: Introdução ao estudo da filosofia, vol. I. Rio de Janeiro: Civilização Brasileira, 1999.

GRIFFITHS, Paul. A Música Moderna. Tradução de Clóvis Marques. Rio de Janeiro: Jorge Zahar, 1998

GROUT, D. J \& PALISCA, C. V. História da Música Ocidental. Lisboa: Gradiva, 2001.

GULLAR, Ferreira. Argumentação contra a morte da arte. Rio de Janeiro: Editora Revan. 1999.

GULLAR, Ferreira. Cultura posta em questão: vanguarda e subdesenvolvimento. Rio de Janeiro: Editora José Olympio. 2002.

GULLAR, Ferreira. Em alguma parte alguma. $6^{\mathrm{a}}$ Ed. Rio de Janeiro: Editora José Olympio, 2013.

GULLAR, Ferreira. Sobre arte / Sobre poesia (uma luz do chão). $1^{\circ}$ Ed. Rio de Janeiro. Editora José Olympio. 2006.

HALL, Stuart. Da diáspora - identidades e mediações culturais. Belo Horizonte: Editora UFMG, 2013. 
HAWKING, Stephen. MLODINOW, Leonard. O Grande Projeto. Rio de Janeiro: Editora Nova Fronteira, 2010.

HAWKING, Stephen. O universo numa casca de noz. Rio de Janeiro: Editora Nova Fronteira, 2002.

HEIDEGGER, Martin. A caminho da linguagem. Tradução de Márcia Sá Cavalcante Schuback. Petrópolis: Vozes, 2003 [conferências e ensaios redigidos entre 1950 e 1959].

HEIDEGGER, Martin. A Origem da Obra de Arte. Tradução de Maria Conceição Costa. Lisboa: Edições 70, 2005 [1935].

HEIDEGGER, Martin. Os Conceitos Fundamentais da Metafísica.Tradução de Marco Antônio Casanova. Rio de Janeiro: Forence, 2006.

JAPIASSU, Hilton \& MARCONDES, Danilo. Dicionário básico de filosofia. $3^{\text {a }}$ ed. revista e ampliada. Rio de Janeiro: Jorge Zahar, 1996.

JAPIASSU, Hilton. A crise das ciências humanas. São Paulo: Cortez, 2012.

JIMÉNEZ, Ariel. Ferreira Gullar Conversa com Ariel Jiménez. Tradução de Vera Pereira. $1^{\text {a }}$ Edição. São Paulo: Cosac Naify, 2013.

KANT, Immanuel Kritik der Urteilskraft, 1790

KANT, Immanuel. Kritik der reinen Vernunft. Riga: Johann Friedrich Hartknoch, 1781.

KANT, Immanuel. Reflexões sobre Antropologia (1776-1778).

KANT, Immanuel. Vorlesungen über Metaphysik. (1772-1773).

KIERKEGAARD, Sören. Entweder, Oder. Teil I und II. [Taschenbuch]. 1846

LESSEN, Alan. Schönberg,Stravinsky, and Neo-Classicism: The Issues Reexamined. Oxford: Oxford University Press, 1982. In: The Musical Quarterly, Vol. 68, No. 4, Oct., 1982.

MATTEI, Jean-François. A Barbárie Interior - Ensaio sobre o i-mundo moderno. Tradução de Isabel Maria Loureiro. São Paulo: Editora Unesp, 2002.

MATTEI, Jean-François. L'art de l'insignifiance ou la mort de l'art. Conferência realizada em Cannes, e publicada em forma de artigo nos anais em www.artefilosofia.com, em 19 de março de 2004.

MOLINO, Jean. Facto musical e semiologia da música, In: Semiologia da música, Nattiez, J.J, Eco, U.,Ruwer, N., Lisboa: Vega, Universidade, s/d. 
MORIN, Edgar. Rumo ao abismo?: ensaio sobre o destino da humanidade. Tradução de Edgard de Assis Carvalho, Mariza Perassi Bosco. Rio de Janeiro: Bertrand Brasil, 2011.

NATTIEZ, J.J. Facto musical e semiologia da música, In: Semiologia da música, Molino, Jean, Eco, U.,Ruwer, N., Lisboa: Vega, Universidade, s/d.

ONFRAY, Michel. Contra-História da Filosofia. I. Sabedorias Antigas. Tradução de Monica Stahel. São Paulo: Martins Fontes, 2008.

ONFRAY, Michel. Tratado de Ateologia. Editora WMF Martins Fontes. São Paulo. Tradução de Monica Stahel. 2a edição. 2014.

ORTEGA Y GASSET, José. A Desumanização da Arte. Tradução de Ricardo Araújo.

NORDWALL, Ove. Lutoslawski. Hansen, 1968

PAREYSON, Luigi. Estética - Teoria da formatividade. Tradução de Ephraim Ferreira Alves. Petrópolis: Vozes, 1993 [1ª ed. 1954].

PAREYSON, Luigi. Os problemas da estética. Tradução de Maria Helena Nery Garcez. $3^{\mathrm{a}}$ ed. São Paulo: Martins Fontes, 1997 [1 ${ }^{\mathrm{a}}$ ed. italiana 1966].

PAREYSON, Luigi. Os problemas da estética. Tradução de Maria Helena Nery Garcez. $3^{\mathrm{a}}$ ed. São Paulo: Martins Fontes, 2001 [1 ${ }^{\mathrm{a}}$ ed. 1966].

PAREYSON, Luigi. Verdade e Interpretação. Traduções de Maria Helena Nery Garcez e Alves. Petrópolis: Vozes, 2005.

POMBO, Olga. Epistemologia e interdisciplinaridade. Publicação do seminário Internacional Interdisicplinaridade, Humanismo, Universidade. Faculdade de Letras da Universidade do Porto, 2003.

RICCIARDI, Rubens. Música na madrugada do destino - uma poética musical para o século XXI, In: Quatro ensaios sobre filosofia da música, Costa, A.; Sekeff, M ${ }^{a}$ L.; Zampronha, E.; Ribeirão Preto: Coruja, 2013.

RICCIARDI, Rubens. Paradoxos modernistas. In: Movimento Vivace. Ribeirão Preto: OSRP. Ano I, nº $10-2008$.

ROSEN, Charles. Ensaio Crítico sobre a História da Música Ocidental de Richard Taruskin. Ediouro: Revista Diapason Brasil nº.2, maio/junho de 2006.

ROUVILLOIS, Frédéric. Histoire du snobisme. Paris: Flammarion, 2008

RUSS, Jacqueline. Dicionário de Filosofia. Tradução de Alberto Alonso Muñoz. São Paulo: Scipione, 1994 [1ª ed. Paris: Bordas, 1991]. 
SANDOW, Greg. Boulez and Godard, In: Rebirth: The Future of Classical Music. Traduzido por Leonardo T. Oliveira. Hospedado em http://euterpe.blog.br/historia-damusica/a-crise-da-musica-classica-por-greg-sandow, 2012

SCHÖNBERG, Arnold. Fundamentos da Composição Musical. Tradução de Eduardo Seincman. São Paulo: EDUSP, 1996 [1ª ed. 1967].

SCHÖNBERG, Arnold. Harmonielehre. [Wien]: Universal, 1986 [1ª ed. 1911].

SCHÖNBERG,. Style and Idea. Edited by Leonard Stein - Translations by Leo Black. University of California Press, 1984 [1 $1^{\text {a }}$ ed. 1950 - New York: Philosophical Library].

SOUSA SANTOS, Boaventura de. Um Discurso sobre as Ciências. Porto: Edições Afrontamento, 1988.

SOUSA SANTOS, Boaventura de; MENESES, Maria Paula (orgs.). Epistemologias do Sul. São Paulo: Cortez, 2010.

STEHMAN, Jacques. História da música européia - das origens aos nosso dias. Tradução de Maria Teresa Athayde. Revisão técnica de Fernando Cabral. $2^{\mathrm{a}}$ ed. Lisboa: Livraria Bertrand, 1979 [1 ${ }^{\text {a }}$ ed. belga 1964].

STRAVINSKY, Igor. Poética musical em seis lições. Tradução de Luiz Paulo Horta. Rio de Janeiro: Jorge Zahar, 1996 [1ª ed. 1942 - originais de 1939/1940].

SUPICIC, Ivo. Les approches socio-historiques de l'oeuvre musicale. Croácia: Publicado por: Croatian Musicological Society. 1986. (acessado em 2010).

TALON-HUGON, Carole. A Estética, História e Teorias. Tradução de Antônio Maia da Rocha. Lisboa: Texto \& Grafia, 2008.

TERRA, Vera. Acaso e Aleatório na Música: Um estudo da indeterminação nas poéticas de Cage e Boulez. São Paulo: EDUC. 2000.

TRAGTENBERG, Lívio (org.). O ofício do compositor hoje. São Paulo, Perspectiva, 2012. Signos Música, 2012.

UCHOA LEITE, Sebastião. A Espreita. São Paulo. Perspectiva. Coleção Signos, 2000.

WEBER, William. The history of the Musical Canon. In: COOK, Nicholas \& Everist, Mark (editors). Rethinking Music. Oxford, Oxford University Press, 2010.

WEBERN, Anton. O caminho para a música nova - (ensaios). São Paulo, Novas. (1984). 